\title{
Tectono-Metamorphic Evolution of the Snowcap Assemblage, Yukon-Tanana Terrane, West-Central Yukon
}

by

Yannick Eric Morneau

A thesis submitted to the Faculty of Graduate and Postdoctoral Affairs in partial fulfillment of the requirements for the degree of

Master of Science

in

Earth Sciences

Carleton University

Ottawa, Ontario

(C) 2017, Yannick Eric Morneau 


\begin{abstract}
Quantitative and qualitative analyses of Snowcap Assemblage metapelitic rocks of the Yukon-Tanana terrane (YTT) in west-central Yukon results in the identification of three phases of metamorphism and deformation through garnet crystallization modeling coupled with garnet age dating. A first Permo-Triassic metamorphic event (ca. $245 \mathrm{Ma}$ ), associated with a heating event occurring during the emplacement of Permian granitoids, reached low $\mathrm{P}$ amphibolite facies metamorphic conditions. The second metamorphic event dated at the Jurassic (ca. 197-188 Ma) reached peak P-T conditions of 7 kbar and $650-685^{\circ} \mathrm{C}$ with a heating rate of $20^{\circ} \mathrm{C} / \mathrm{My}$ and is followed by a dwell period at $\mathrm{T}>600$ ${ }^{\circ} \mathrm{C}$. This event follows typical Barrovian-type metamorphism and is interpreted to be associated with the accretion of the YTT onto Laurentia. The third metamorphic event, post-Jurassic in age, reached peak P-T conditions of $6 \mathrm{kbar}$ and $580{ }^{\circ} \mathrm{C}$ with a heating rate of $20^{\circ} \mathrm{C} / \mathrm{My}$.
\end{abstract}




\section{Acknowledgements}

Foremost, thanks to my supervisors: Fred Gaidies, Alex Zagorevski, and Jim Ryan. Fred, thanks for having me as part of your research group, I have learned a lot through this great opportunity. Alex, thanks for all the numerous advice and feedback you have given me. Jim, thank you for the opportunity to work with you in the field during the last two summers. Working in the Yukon was a fantastic experience! Thanks to the Geological Survey of Canada for funding this research. Thanks to Tim Mount for helping with the preparation of central garnet thin sections and for allowing me access to the rock lab at Carleton University. Thanks to Peter Jones for all the electron microprobe work and to Pat Hunt for the SEM work. Thanks to Robert Anczkiewicz for conducting garnet Sm-Nd and Lu-Hf geochronology on my samples. Thanks to Ingrid Kjarsgaard, David Shneider, and George Dix who were a part of the examination committee. Thanks to Freya George, Carolyn Dziawa, and Balie Walker for insightful metamorphic-related discussions. A final thank you goes to my family and friends for the great support you provided. 


\section{Table of Contents}

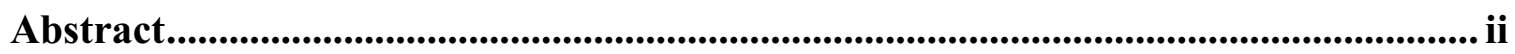

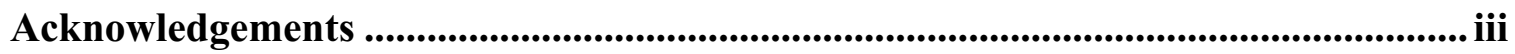

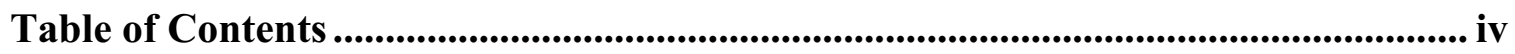

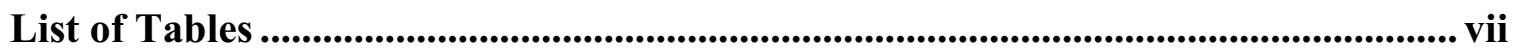

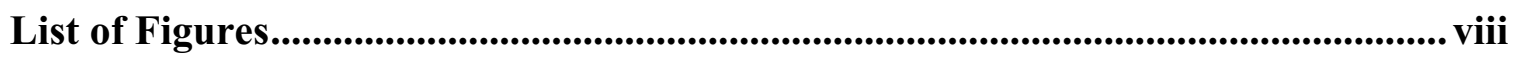

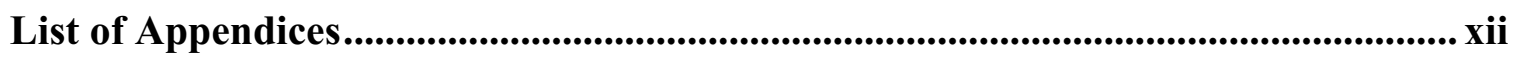

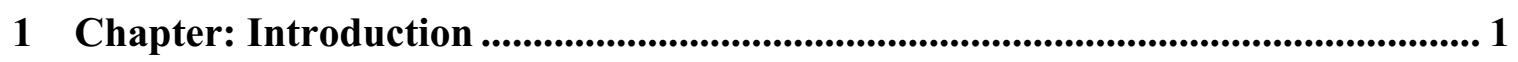

Estimating Conditions and Timing of Metamorphism ........................................... 1

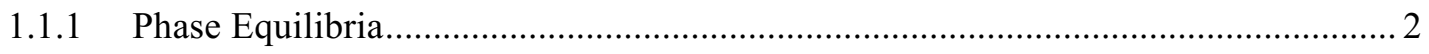

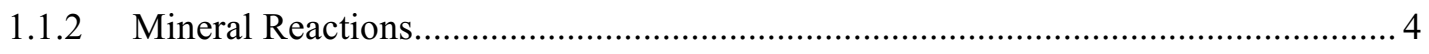

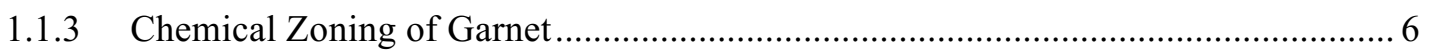

1.1.4 Fractional Crystallization and Forward Modeling ….......................................... 7

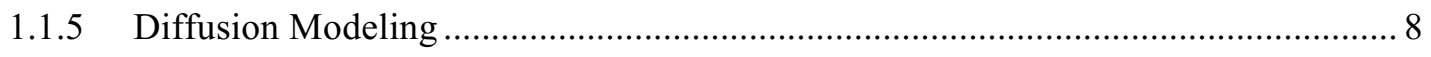

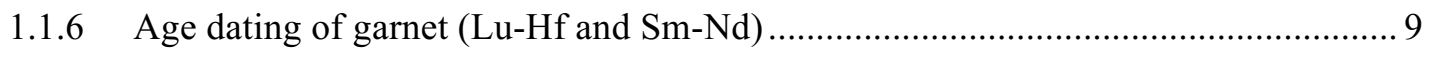

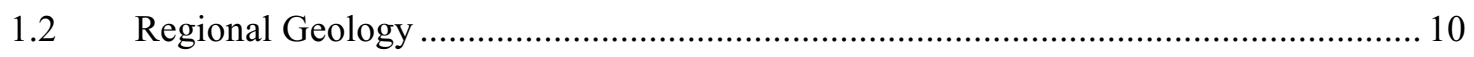

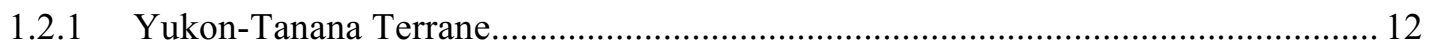

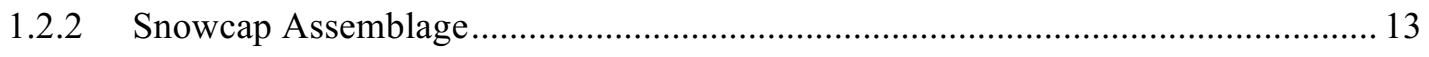

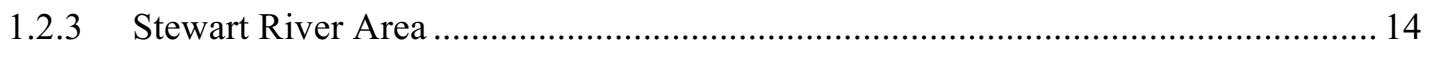

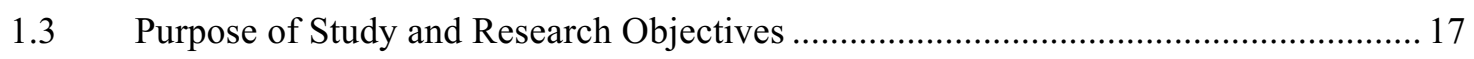

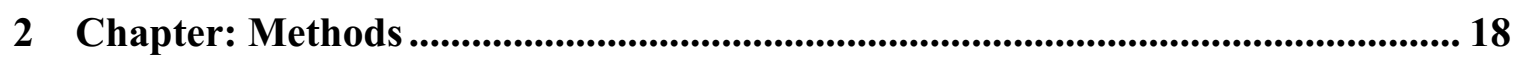

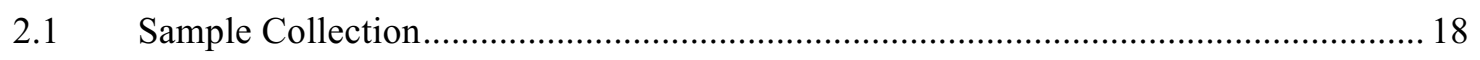

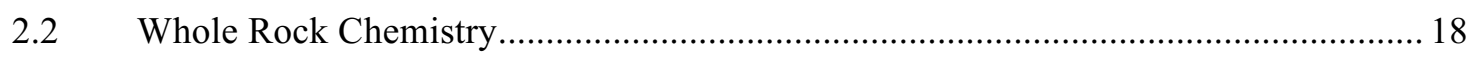

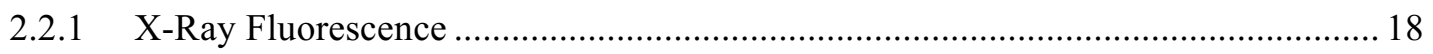

2.2.2 Inductively Coupled Plasma Optical Emission Spectrometry …............................ 19 


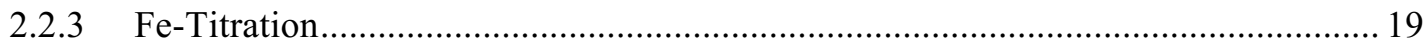

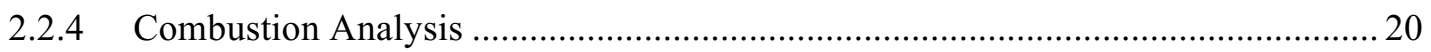

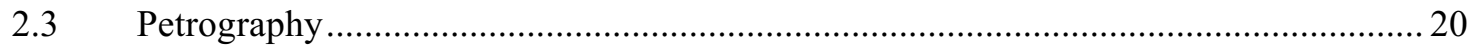

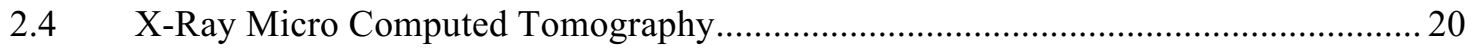

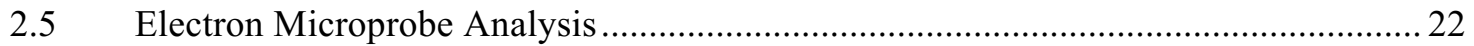

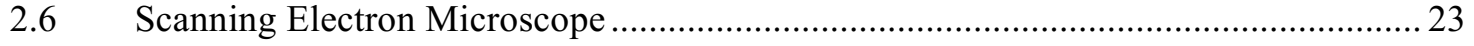

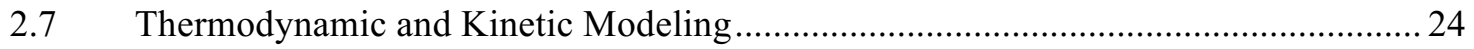

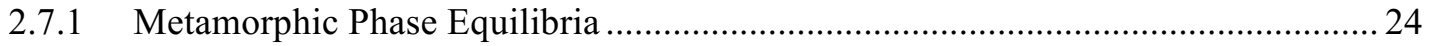

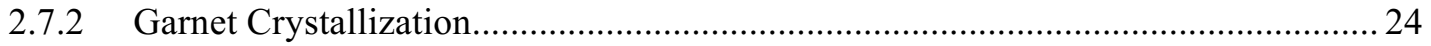

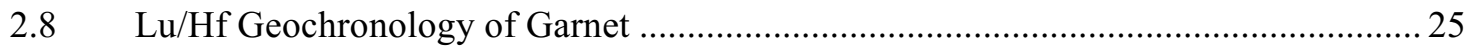

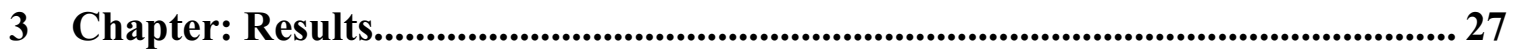

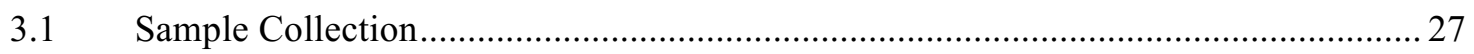

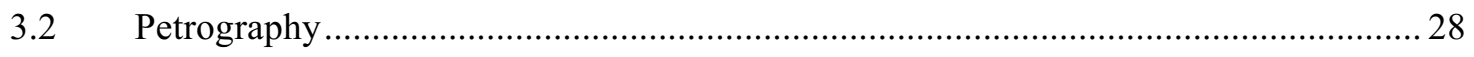

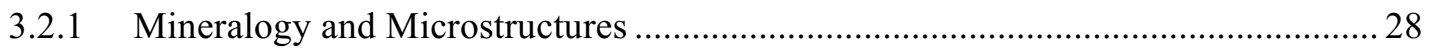

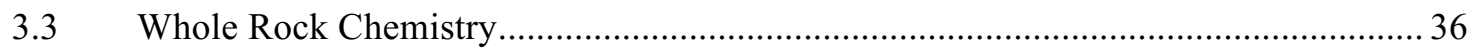

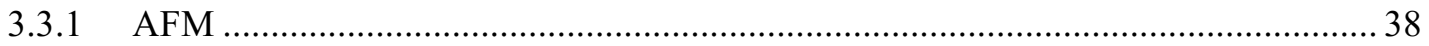

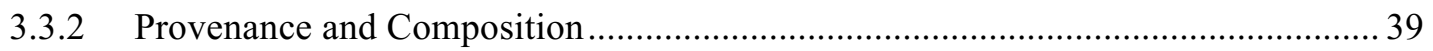

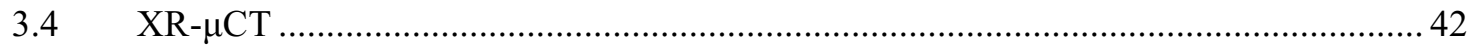

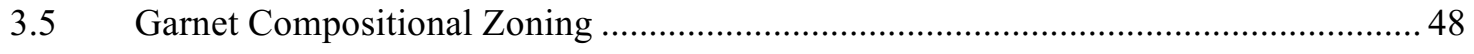

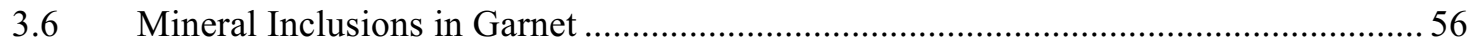

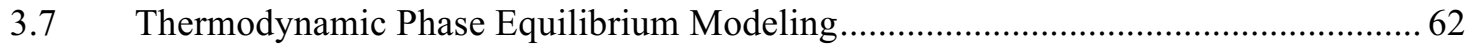

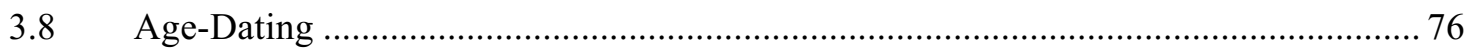

4 Chapter: Interpretations and Discussion .................................................................. 81

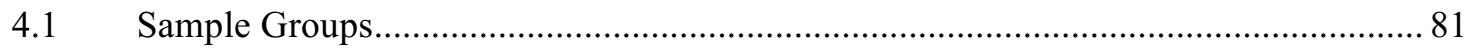

4.2 Uncertainties in Thermodynamic Modeling ....................................................... 84

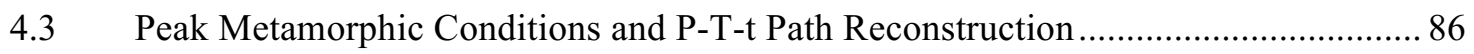




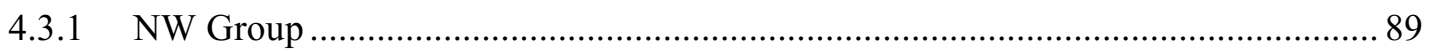

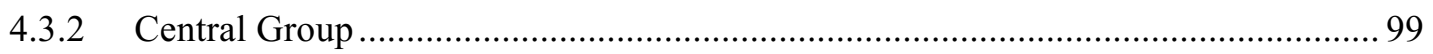

4.3.3 Chemical Fractionation and Resulting Changes in Equilibrium Assemblages ...... 110

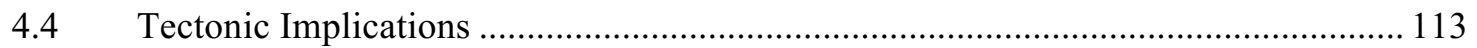

5 Chapter: Conclusions ........................................................................................ 122

Appendices............................................................................................................................ 125

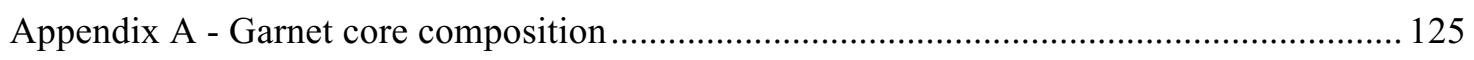

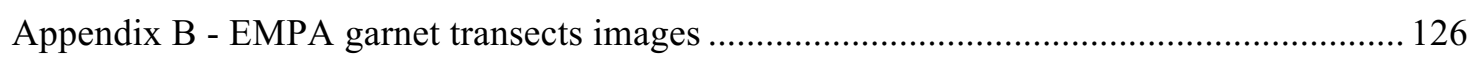

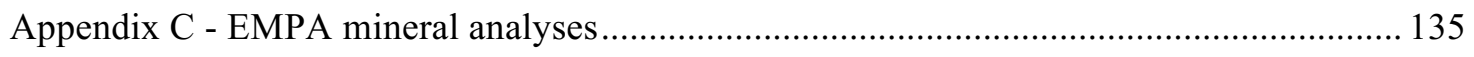

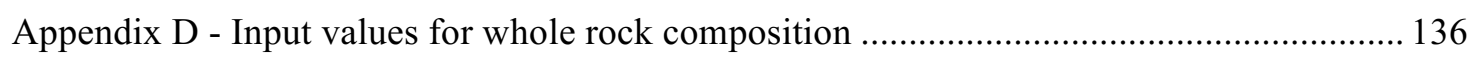

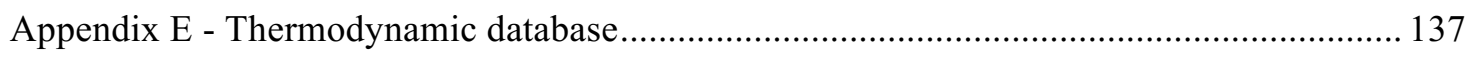

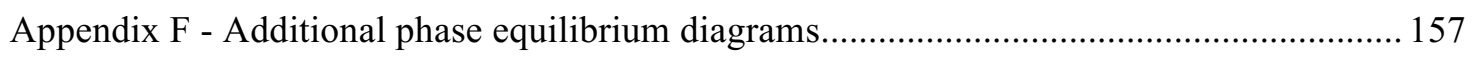

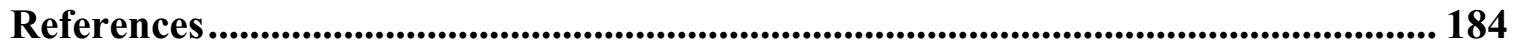




\section{List of Tables}

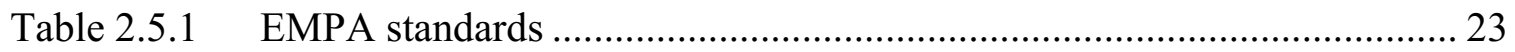

Table 3.1.1 Sample location coordinates ............................................................ 27

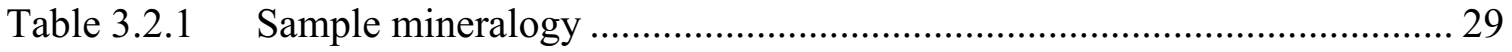

Table 3.3.1 Major element whole rock compositions .............................................. 37

Table 3.3.2 Trace element compositions ............................................................ 38

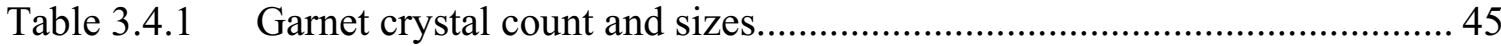

Table 3.6.1 Summary of inclusions observed in garnet ........................................ 56

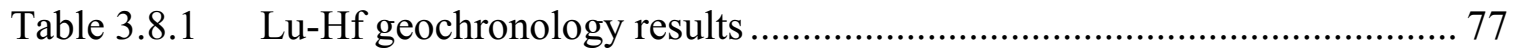

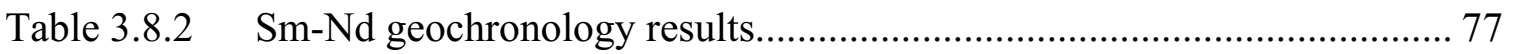

Table 4.1.1 Group similarities and differences ............................................... 822

Table 4.1.2 Group comparison for ranges of whole rock composition....................... 84

Table 4.3.1 Fractionated whole rock elemental composition post garnet growth ..... 888

Table 4.3.2 Modeled P-T-t path of sample 15RAYJR237B .................................. 900

Table 4.3.3 Modeled P-T-t path of sample 15RAYJR246A................................... 966

Table 4.3.4 Modeled P-T-t path of sample 00RAY098A.................................... 1000

Table 4.3.5 Modeled P-T-t path of sample 00RAY231A.................................... 1077 


\section{List of Figures}

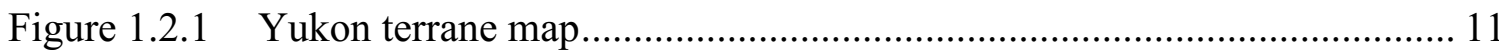

Figure 1.2.2 Geological map of the study area with sample locations.......................... 15

Figure 3.2.1 Thin section microphotographs of samples in the northwest part of the

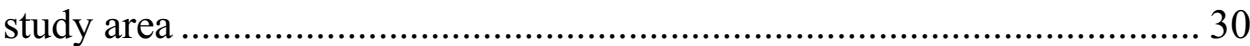

Figure 3.2.2 Thin section sketch of microstructures in samples 15RAYJR232A1 and

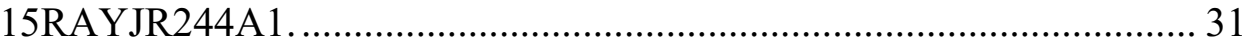

Figure 3.2.3 Thin section microphotographs of samples in the central part of the study area 33

Figure 3.2.4 Thin section microphotographs of samples near Scroggie Creek pluton . 34

Figure 3.2.5 Thin section microphotographs of other samples ................................... 36

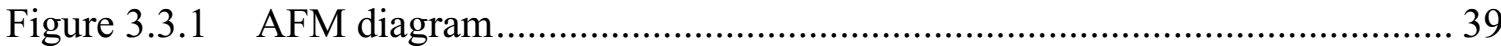

Figure 3.3.2 Sedimentary protolith diagram ……………………………………..... 40

Figure 3.3.3 Depositional environment diagram............................................................ 41

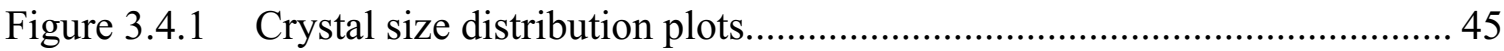

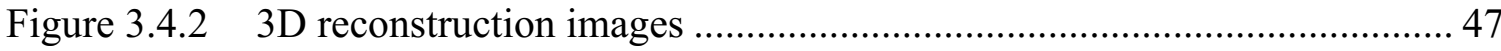

Figure 3.5.1 Garnet compositional profiles of the largest garnet crystals in samples 15RAYJR237B, 15RAYJR246A, and 15RAYJR241A.

Figure 3.5.2 Garnet compositional profiles of the largest garnet crystals in samples 00RAY098A, and 00RAY231A

Figure 3.5.3 Garnet compositional profiles of the largest garnet crystals in samples

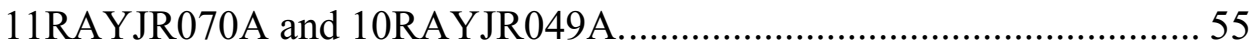

Figure 3.6.1 SEM images of inclusions in garnet in sample 15RAYJR237B.............. 57 
Figure 3.6.2 SEM images of inclusions in garnet in sample 15RAYJR246B.............. 59

Figure 3.6.3 SEM images of inclusions in garnet in sample 00RAY098A.................. 60

Figure 3.6.4 SEM images of inclusions in garnet in sample 00RAY231A................ 61

Figure 3.7.1 Phase equilibrium diagram for sample 15RAYJR237B....................... 63

Figure 3.7.2 Garnet end-member isopleths of sample 15RAYJR237B...................... 64

Figure 3.7.3 Phase equilibrium diagram for sample 15RAYJR246A........................ 65

Figure 3.7.4 Garnet end-member isopleths for sample 15RAYJR246A..................... 66

Figure 3.7.5 Phase equilibrium diagram for sample 15RAYJR241A......................... 67

Figure 3.7.6 Garnet end-member isopleths for sample 15RAYJR241A..................... 68

Figure 3.7.7 Phase equilibrium diagram for sample 00RAY098A........................... 69

Figure 3.7.8 Garnet end-member isopleths for sample 00RAY098A........................ 70

Figure 3.7.9 Phase equilibrium diagram for sample 00RAY231A.......................... 71

Figure 3.7.10 Garnet end-member isopleths for sample 00RAY231A..................... 72

Figure 3.7.11 Phase equilibrium assemblage diagram and garnet end-member isopleths for sample 11RAYJR070A......................................................... 74

Figure 3.7.12 Phase equilibrium assemblage diagram and garnet end-member isopleths for sample 10RAYJR049A....................................................... 75

Figure 3.8.1 Lu-Hf garnet-whole rock isochron for sample 15RAYJR246A .............. 78

Figure 3.8.2 Sm-Nd garnet-whole rock isochron for sample 15RAYJR246A........... 78

Figure 3.8.3 Lu-Hf garnet-whole rock isochron for sample 00RAY098A................. 79

Figure 3.8.4 Sm-Nd garnet-whole rock isochron for sample 00RAY098A................ 79

Figure 3.8.5 Lu-Hf garnet-whole rock isochron for sample 00RAY231A................ 80

Figure 3.8.6 Sm-Nd garnet-whole rock isochron for sample 00RAY231A................ 80 
Figure 4.1.1 Map of the study area containing the mineralogy, groups and geochronology 833

Figure 4.3.1 Peak mineral assemblage fields for all samples................................ 877

Figure 4.3.2 P-T path of sample 15RAYJR237B ............................................... 900

Figure 4.3.3 Modeled garnet compositional profiles for sample 15RAYJR237B ..... 911

Figure 4.3.4 Comparison of different bulk $\mathrm{FeO}$ on phase equilibrium relations for sample 15RAYJR237B ............................................................ 944

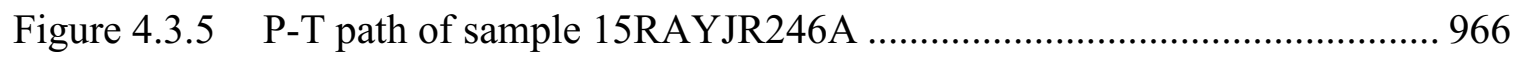

Figure 4.3.6 Modeled garnet compositional profiles for sample 15RAYJR246A..... 977

Figure 4.3.7 P-T path for first phase of garnet growth in sample 00RAY098A...... 1000

Figure 4.3.8 Modeled garnet compositional profiles for first episode of garnet growth in sample 00RAY098A. 1011

Figure 4.3.9 Garnet end-member isopleths for fractionated whole rock composition after first phase of garnet growth in sample 00RAY098A. 1044

Figure 4.3.10 P-T path for both garnet growth episodes in sample 00RAY098A.. 1055

Figure 4.3.11 Modeled garnet compositional profiles for entire garnet growth in sample 00RAY098A. 1066

Figure 4.3.12 P-T path for the first garnet growth episode in sample 00RAY231A 1088

Figure 4.3.13 Modeled garnet compositional profile for first episode of garnet growth in sample 00RAY231A 10909

Figure 4.3.14 Phase equilibrium diagram comparison between whole rock composition and fractionated rock composition for sample 15RAYJR237B 1111 
Figure 4.3.15 Phase equilibrium diagram comparison between whole rock composition and fractionated rock composition for sample 15RAYJR246A 1111

Figure 4.3.16 Phase equilibrium diagram comparison between whole rock composition and fractionated rock composition for sample 00RAY098A 1122

Figure 4.4.1 Comparison of P-T-t paths for samples 15RAYJR237B, 15RAYJR246A, 00RAY098A and 00RAY231A with ages of garnet growth . 1166

Figure 4.4.2 Summary of conclusive metamorphic events observed in the Stewart River area. 1177 


\section{List of Appendices}

Appendix A - Garnet core compositions.................................... 125

Appendix B - EMPA garnet transect images.................................... 126

Appendix C - EMPA mineral analyses...................................... 135

Appendix D - Whole rock composition input values for modeling.................. 136

Appendix E - Thermodynamic database.................................... 137

Appendix F - Additional phase equilibrium diagrams.......................... 157 


\section{Chapter: Introduction}

The research presented in this thesis describes the tectono-metamorphic conditions and timing of the formation of the Snowcap Assemblage in the Stewart River area in westcentral Yukon using a combination of analytical techniques.

\subsection{Estimating Conditions and Timing of Metamorphism}

A metamorphic event is the recrystallization of a rock as a consequence of changes in pressure $(\mathrm{P})$, temperature $(\mathrm{T})$, and the rock's chemical composition $(\mathrm{X})$. The change of $\mathrm{P}$, $\mathrm{T}$, or $\mathrm{X}$ causes the assemblage of a rock to become thermodynamically unstable and causes it to change in order to reach thermodynamic equilibrium. Equilibrium is achieved by crystallizing the mineral phase assemblage that yields the lowest possible Gibbs energy (Spear, 1993) for a given P-T-X system. Such stable mineral assemblage can therefore be calculated if the thermodynamic properties of all possible mineral and fluid phases involved are known.

In a metamorphic rock, some mineral phases can be key indicators of the peak conditions achieved. Examples in metapelitic rocks include garnet, staurolite, kyanite, sillimanite, andalusite, chlorite, chloritoid, rutile, etc. These minerals only form under specific metamorphic conditions and can be used to interpret the metamorphic grade of the rock. For example, sillimanite is an indicator of relatively high temperatures, while andalusite is an indicator of relatively low pressures. Each of these minerals help to further refine the possible peak conditions experienced by the rock. 


\subsubsection{Phase Equilibria}

Phase equilibria consist of the stable mineral assemblages that form at fixed P-T-X conditions. With variations in conditions, such as $\mathrm{P}$ or $\mathrm{T}$, phases involved require different levels of energy to be sustained, leading to some phases being favorable over others (Spear, 1993). Any system will naturally work to achieve the lowest possible Gibbs energy, which represents chemical equilibrium under constant pressure and temperature in a closed system. Over the recent decades, thermodynamic equilibrium modeling techniques have become progressively more common to characterize the metamorphic conditions of recrystallized rocks (Baldwin et al., 2005; Berman, 1991; Berman et al., 2007; Connolly, 2005; de Capitani and Brown, 1987; de Capitani and Petrakakis, 2010; Gaidies et al., 2006; 2015; Spear, 1993; etc.).

The mineral assemblage in metamorphic rocks can be calculated for a system using the thermodynamic properties of all phases present for a given P-T-X point by identifying the assemblage that yields the lowest Gibbs energy (e.g. Berman, 1988; Holland and Powell, 1998). This process is referred to as Gibbs energy minimization, and is used to calculate stable assemblages with software such as Theriak (de Capitani and Brown, 1987) or Vertex (Connolly, 1990). When calculating these assemblages, several assumptions must be made about the system: (1) there is chemical equilibrium with respect to all system components across individual mineral grains and between them; (2) mineral reactions occur instantly with changes in P-T conditions; (3) there are no changes in the composition of the rocks (e.g. through external fluids). 
Software like Theriak-Domino (de Capitani and Petrakakis, 2010) or THERMOCALC (Powell and Holland, 1988) can be used to calculate phase equilibrium diagrams, which display stable mineral assemblages across a range of $\mathrm{P}$ and $\mathrm{T}$ conditions while using a constant bulk composition. The Theriak-Domino software uses Gibbs energy minimization for its phase equilibrium modeling. Assuming that studied metamorphic rocks retain their peak metamorphic assemblages, their mineralogy will directly represent the mineral assemblage that is stable at the peak conditions experienced during the metamorphic event. The whole rock chemical composition is used as the composition of the system, and used to obtain stable mineral assemblage fields.

Textural observations of rocks can be used to complement the phase equilibrium results. For example, if a mineral phase is observed replacing another in the rock (e.g. staurolite replacing chlorite), peak conditions of the rock can be inferred to be close to the phase change boundary (e.g. chlorite-out, staurolite-in reactions) on the phase diagram.

For mineral phases that form a solid solution of several end-member components, such as garnet and feldspar, the relative proportions of their end-members will change with variations in $\mathrm{P}, \mathrm{T}$ and $\mathrm{X}$ (Spear, 1993). It is important to consider all phases as they can help to narrow down peak metamorphic conditions.

Garnet in metapelitic rocks consists of a mix of end-members, which varies as a function of whole rock chemistry, temperature, pressure, and the presence of other mineral phases 
(Spear et al., 1991). The four most common end-members of garnet are pyrope, almandine, grossular and spessartine:

$$
\begin{array}{ll}
\text { Pyrope: } & \mathrm{Mg}_{3} \mathrm{Al}_{2}\left(\mathrm{SiO}_{4}\right)_{3} \\
\text { Almandine: } & \mathrm{Fe}_{3} \mathrm{Al}_{2}\left(\mathrm{SiO}_{4}\right)_{3} \\
\text { Grossular: } & \mathrm{Ca}_{3} \mathrm{Al}_{2}\left(\mathrm{SiO}_{4}\right)_{3} \\
\text { Spessartine: } & \mathrm{Mn}_{3} \mathrm{Al}_{2}\left(\mathrm{SiO}_{4}\right)_{3}
\end{array}
$$

\footnotetext{
Almandine and pyrope contents of garnet are mostly temperature dependent, increasing with higher temperatures (Spear, 1993). Grossular content is mostly dependent on pressure, increasing significantly with higher pressures, but also decreasing with increasing temperatures. Whole-rock Mn content is consumed rapidly at the start of garnet growth, and decreases as garnet grows. It is preferentially consumed by garnet, and small variations of Mn content in the bulk rock chemistry can significantly change the conditions at which garnet first crystallizes. Higher bulk Mn contents will lead to garnet forming at lower metamorphic T conditions. Phases like garnet can therefore be used to narrow the peak P-T field experienced by a rock if the concentration of each endmember is known.
}

\subsubsection{Mineral Reactions}

Mineral reactions that occur as a result of changes in P-T conditions are not instantaneous. When minerals break down, nutrients take time to travel from one phase to another, where they need to be arranged to form the crystal structure. Each element in a system behaves differently in terms of their mobility, which also depends on the 
hydration state of the rock. As a result, some minerals may be present outside of their predicted stability field. Unstable and metastable reactants can occasionally be observed in rocks and can indicate, in the case of a prograde reaction, that the peak conditions reached were beyond the P-T conditions of their breakdown reaction.

Reactions that nucleate new phases need additional energy to breach the kinetic barrier that is required for nucleation (Pattison et al., 2011). This results in their formation at different conditions than predicted by equilibrium thermodynamics. This process can be referred to as overstepping when happening during prograde metamorphism (Rubie, 1998; Pattison et al., 2011), and can be significant in reactions that include nucleation. In metapelitic rocks, metamorphic reactions that include nucleation can require overstepping by as much as $30{ }^{\circ} \mathrm{C}$ beyond equilibrium for garnet, $40{ }^{\circ} \mathrm{C}$ for staurolite and $80{ }^{\circ} \mathrm{C}$ for kyanite (Pattison and Tinkham, 2009; Waters and Lovegrove, 2002).

Observed phase assemblages in rocks are assumed to reflect peak mineral assemblages, but additional mineral reactions can occur along the retrograde $\mathrm{P}-\mathrm{T}$ path if the right conditions are met and sustained. For example, retrograde chlorite forms if the rocks are hydrated and can often be observed replacing phases such as biotite or forming rims around garnet. If the chlorite formed during the cooling path, it must not be considered part of the peak mineral assemblage.

Mineral nucleation can occur over the entire P-T field where the respective phase is a part of the assemblage. For example, garnet abundance tends to increase with increasing P-T 
conditions, and depending on the conditions, it may be favorable for new garnet crystals to nucleate rather than only growing on pre-existing garnet crystals. Garnet crystal sizes can be representative of the time of nucleation (Cashman and Ferry, 1988; Gaidies et al., $2008 ; 2011)$ if all garnet crystals grow at the same rate. Therefore, the largest garnet crystal represents the first to have crystallized. The crystal size distribution (CSD) can be informative about the growth rates of mineral phases such as garnet as a result of metamorphism. Typical patterns for garnet are normal and positively skewed unimodal distributions (Cashman and Ferry, 1988; Gaidies et al., 2008). Additionally, if a rock has experienced several phases of metamorphism, the CSD may show a polymodal distribution of garnet if nucleation of new crystals occurs for each phase of metamorphism. If additional garnet growth only occurs on pre-existing garnet crystals, then the CSD will remain unimodal.

\subsubsection{Chemical Zoning of Garnet}

Rocks subjected to phase equilibrium modeling are commonly assumed to be chemically homogeneous. This assumption is incorrect in samples containing chemically zoned minerals such as garnet (Carlson, 2006; Chakraborty and Ganguly, 1992; Evans, 2004; Gaidies et al., 2006, Hollister, 1966). For garnet, which has a rhombic dodecahedral crystal habit, the geometric core generally represents the nucleation point, and the outer surface represents the last part of the crystal to have grown. The presence of chemical zoning can be attributed to slower diffusion rates than crystal growth rates. As a result, end-member components do not have time to equilibrate. Zoning in garnet can be attributed to two related processes: (1) changes in P-T conditions, or (2) changes in X of 
the bulk rock (Cygan and Lasaga, 1982; Hickmott et al., 1987).

The influence of changing $\mathrm{X}$ on garnet chemical zoning is important for understanding $\mathrm{P}$ T-t evolution and equilibrium mineral assemblages. As garnet crystals grow bigger, fractionation of elements into garnet changes the availability of nutrients in the whole rock. Crystals that nucleate early during the P-T path will grow from an overall whole rock composition that is less affected by fractionation. Assuming that all crystals grow at an equal rate, the largest garnet crystal represents the first garnet to have nucleated, and its core composition grew from a non-fractionated whole rock composition, assuming that all other mineral phases in the rock are chemically equilibrated (Gaidies et al., 2008). The first garnet crystal to have nucleated thus becomes important for constraining the P-T path.

\subsubsection{Fractional Crystallization and Forward Modeling}

Fractional crystallization modeling requires removal of non-homogenized mineral compositions out of the whole rock composition in order to obtain the consumable effective bulk composition. Fractional crystallization models assume that only the rims of zoned minerals are kept at equilibrium with the whole rock at any time during their growth (Spear, 1993).

The fractional crystallization process can be utilized in forward modeling methods (Spear, 1993). THERIA_G (Gaidies et al., 2008) is a forward modeling software that models garnet crystallization. This software progressively calculates the chemistry of 
garnet as it nucleates and grows along a predefined P-T-time (t) path. As garnet crystals grow their evolving composition is fractionated out of the rock composition, which in turn affects the composition of the following growth layer and phase assemblage. The software considers the crystal size distribution of garnet to define the quantity of crystals that nucleate at different times along the P-T-t path. The number of garnet crystals that nucleate in a volume of rock dictates how big they will grow. Once the model finishes to simulate the growth of garnet, the modeled compositional profile of different size classes of garnet can be extracted and compared to the actual compositional profile of garnets in the sample. The P-T-t path can then be modified until the best matching garnet composition is met (George and Gaidies, 2017; Gaidies et al., 2008).

\subsubsection{Diffusion Modeling}

The process of intracrystalline diffusion consists of the transfer of elements across crystals in order to achieve thermodynamic homogeneity. Diffusion rates vary across elements for different phases and are a function of $\mathrm{T}, \mathrm{t}$ and the crystal size (Spear, 1993). At higher temperatures, diffusion occurs at a faster rate. Diffusion commonly becomes effective in garnet at temperatures above $585-600^{\circ} \mathrm{C}$ for durations above $5 \mathrm{My}$ in crystals of up to $3 \mathrm{~mm}$ in diameter (Caddick et al., 2010; Florence and Spear, 1991). In general, bigger ions with larger charges have slower diffusion rates. Considering the four main end-member cations of garnet $\left(\mathrm{Ca}^{2+}, \mathrm{Fe}^{2+}, \mathrm{Mg}^{2+}\right.$, and $\left.\mathrm{Mn}^{2+}\right), \mathrm{Ca}^{2+}$ forms the largest cation and has the slowest diffusion rates. $\mathrm{Mn}^{2+}$ and $\mathrm{Fe}^{2+}$ diffuse faster and can often be used to constrain the degree of diffusion (also referred to as diffusional relaxation) in a given crystal. 


\subsubsection{Age dating of garnet (Lu-Hf and Sm-Nd)}

Lu-Hf and Sm-Nd age dating of garnet can provide highly accurate ages representative of the timing of metamorphic garnet crystallization (Smit et al., 2013), because garnet has a high affinity for HREE. Lu is strongly partitioned into garnet, being concentrated in the core and following a distribution similar to Y (Kohn, 2009). Hf has a small partition coefficient in garnet and is therefore weakly incorporated. The Lu-Hf isotope system, in which ${ }^{176} \mathrm{Lu}$ decays to ${ }^{176} \mathrm{Hf}$ through $\beta$-decay, is not affected by diffusion at temperatures $\leq 720{ }^{\circ} \mathrm{C}$ (Scherer et al., 2000), therefore the Lu-Hf system constrains the age of crystallization. Above $720^{\circ} \mathrm{C}$, the Lu-Hf system can be treated as a closure temperature (Duchêne et al., 1997; Dodson, 1973). Similarly, the Sm-Nd system has a closure temperature of approximately $730{ }^{\circ} \mathrm{C}$ (Van Orman et al., 2002), but the partition of Sm into garnet results in an increase of Sm from core to rim (Kohn, 2009). Garnet crystallization ages can be calculated from the isochron formed from isotope fractions measured in garnet separates and the whole rock. Polyphase garnets typically yield Lu-Hf ages respective of the first garnet growth event and $\mathrm{Sm}-\mathrm{Nd}$ ages that averages for all garnet growth.

Lu-Hf ages of garnet can be affected by the presence of zircon inclusions in garnet (Scherer et al., 2000). Zircon crystals can incorporate significant amounts of Hf, while having low concentrations of $\mathrm{Lu}$, leading to small ratios of $\mathrm{Lu} / \mathrm{Hf}$ relative to garnet and the bulk rock. Presence of zircon inclusions in analyzed garnet fractions will therefore yield younger ages. 
Similar observations can be made with the presence of monazite and apatite affecting ratios of Sm-Nd. In this case, inclusions of apatite and monazite can be removed through sulphuric acid leaching (Anczkiewicz et al., 2003), but at the cost of removing some Lu in garnet without affecting zircons. This results in higher precision Sm-Nd ages, but with an increase in the error for Lu-Hf ages.

Ages obtained through Lu-Hf dating techniques are also affected by the selection of garnet crystals within the rock (Smit et al., 2013). Smaller garnet crystals can give younger ages than larger garnet crystals. This can be explained by the assumption that larger garnet crystals are first to crystallize, and that $\mathrm{Lu}$ is rapidly partitioned into initial garnet crystals due to its high partition coefficient in garnet. A possible secondary peak of Lu can result from resorption. Secondary peaks in Lu yield younger ages than the main peak in the core (Kelly et al., 2011). The Lu concentration in the secondary peaks is overshadowed by larger concentrations in the core for large garnet crystals, but is the prominent source of Lu and Hf in smaller crystals.

\subsection{Regional Geology}

The northern Cordillera is an accretionary orogen that formed at the western edge of the Laurentian margin. The orogen formed as a result of successive accretion of allochthonous terranes, occurring from the Upper Permian (Beranek and Mortensen, 2011) throughout the Mesozoic (Monger and Price, 2002; Nelson et al., 2013; Staples et al., 2016). Terranes involved can be divided, from NE to SW, into the Laurentian, the peri-Laurentian, the Arctic, and the Coastal realms (Nelson et al., 2013; Figure 1.2.1). 
The Laurentian realm consists of ancestral North America terranes, which formed the edge of Laurentia prior to accretion. The Peri-Laurentian realm, also referred to as Intermontane terranes, consists of the Slide Mountain, Yukon-Tanana, Quesnel and

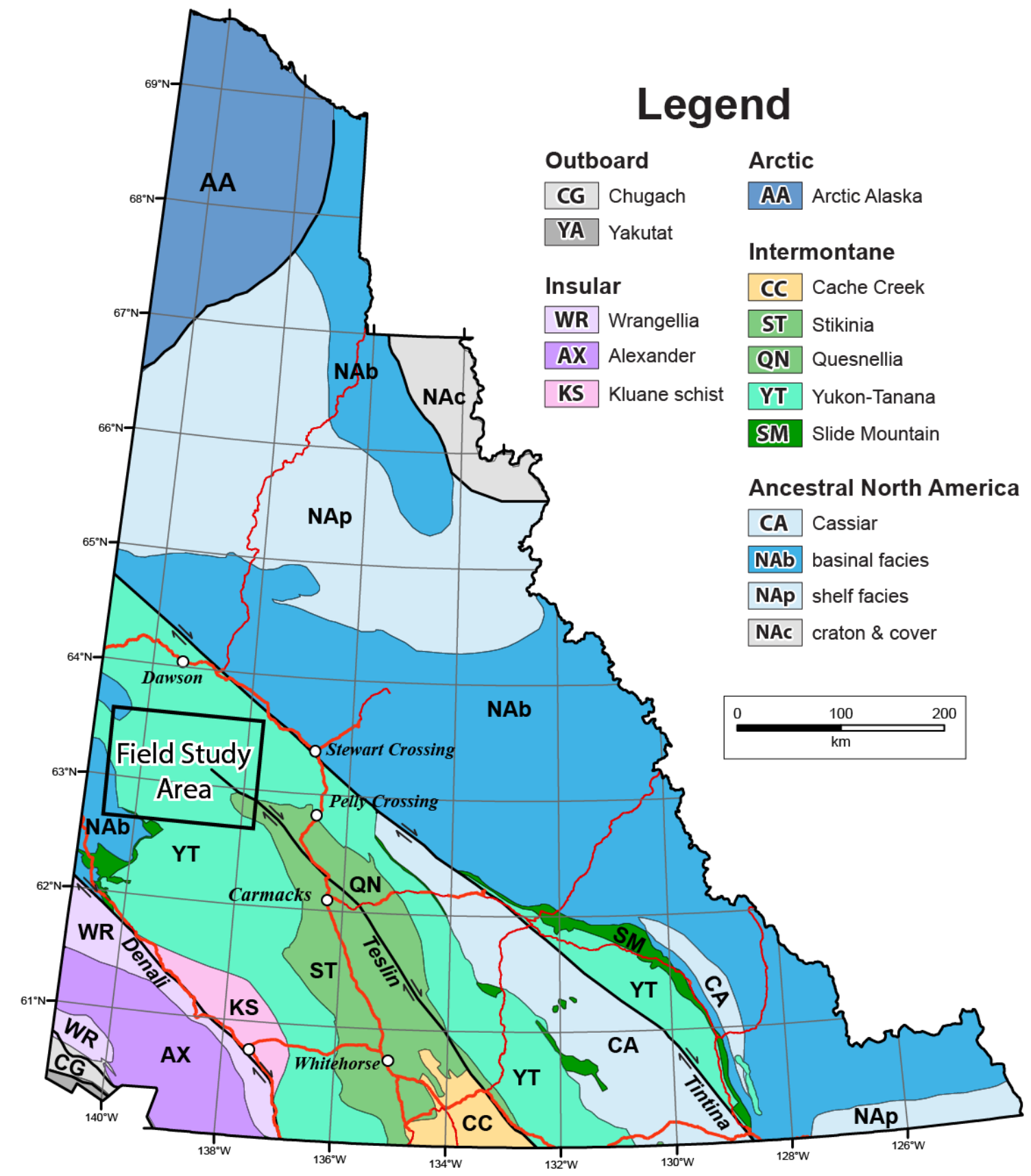

Figure 1.2.1 Yukon terrane map. The study area is in west-central Yukon as indicated. Modified from Colpron and Nelson (2011). 
Stikine terranes. The Slide Mountain terrane is the remnant of an ocean basin between the Laurentian and Peri-Laurentian realms (Figure 1.2.1; Nelson et al., 2013). The Quesnel and Stikine terranes represent intra-oceanic magmatic arcs, and the Yukon-Tanana terrane consists of a magmatic arc that formed on a continental fragment. The Arctic realm consists of the Insular and Northern Alaska terranes, and is mostly observed in Alaska, western British Columbia and southwest and northwest Yukon (Nelson et al., 2013). The Coastal realm forms along the southern coast of Alaska and is observed in the southwest corner of Yukon.

\subsubsection{Yukon-Tanana Terrane}

The basement of the Yukon-Tanana terrane (YTT) consists mostly of metamorphosed siliciclastic sediments derived from Laurentia (Nelson et al., 2013). The sediments were deposited in the western Laurentian margin starting during the Neoproterozoic rifting of Rodinia (Dickinson, 2004) until the Upper Devonian. The separation of the YTT from Laurentia is considered to be a result of back-arc rifting which formed the Slide Mountain Ocean. The YTT re-accreted to the Laurentian margin in the Upper Permian to midCretaceous (Beranek et al., 2010; Berman et al., 2007; Colpron et al., 2007; Beranek and Mortensen, 2011). The accretion was accompanied by diachronous metamorphism reaching amphibolite facies, recorded during the Permo-Triassic, Lower Jurassic, Middle to Upper Jurassic, and Lower to mid-Cretaceous (Dusel-Bacon et al., 1995; Berman et al., 2007; Staples et al., 2013, 2014, 2016; Clark et al., 2016). Plutons of Triassic, Jurassic, and Cretaceous ages have intruded the YTT near the end of its accretion (Woodsworth et al., 1991; Logan and Mihalynuk, 2014). 
The YTT comprises four regional tectono-stratigraphic assemblages, consisting of the pre-Upper-Devonian Snowcap, Upper Devonian Finlayson, Lower Permian Kinklit, and Upper Permian Klondike assemblages. The Snowcap Assemblage is a siliciclastic assemblage of continental margin affinity that forms the basement of the YTT. Deposition of the Snowcap Assemblage sediments occurred prior to Upper Devonian augen granite plutonism (Piercey and Colpron, 2009). The Finlayson, Kinklit, and Klondike are mid- to Upper-Paleozoic volcanic assemblages that are of continental and back-arc affinities, overlaying the Snowcap assemblage. The four regional tectonic assemblages are intruded by the Mississippian Simpson Range suite, the Permian Sulphur Creek suite, the Jurassic Minto and Long Lake plutonic suites, and the mid-Cretaceous Dawson Range batholith (Joyce et al., 2015; Berman et al., 2007; Colpron and Ryan, 2009; Ryan et al., 2014).

\subsubsection{Snowcap Assemblage}

The Snowcap assemblage predominantly consists of pre-Upper Devonian siliciclastic and carbonate metasedimentary rocks. Common rock types include quartzite, metapsammitic schist, carbonaceous schist, marble, calc-silicate rocks and amphibolite (Colpron and Ryan, 2009; Piercey and Colpron, 2009; Ryan et al., 2014). Detrital zircon ages suggest that the Snowcap Assemblage was derived from a northwest Laurentian source (Piercey and Colpron, 2009).

Dykes and sills often intrude units within this assemblage. They commonly preserve textural evidence of poly-deformation and poly-metamorphism with syn- and post- 
tectonic mineral growth (Berman et al., 2007; Piercey and Colpron, 2009). The main schistosity is generally shallow dipping with varying strike orientation (Gordey and Ryan, 2005).

Metapelitic to metapsammitic schists of the Snowcap assemblage in the Stewart River area contain few metamorphic index minerals (Berman et al., 2007). Garnet is occasionally observed, but other amphibolite-facies minerals like staurolite and kyanite are nearly always absent.

\subsubsection{Stewart River Area}

The Stewart River area is located approximately 50 to $100 \mathrm{~km}$ south of Dawson, and 50 to $150 \mathrm{~km}$ west of Stewart Crossing (Figure 1.2.1). Units observed in the area mostly consist of the pre-Upper Devonian Snowcap and Upper Devonian Finlayson assemblages, the Mississippian Simpson Range, the Permian Klondike assemblage, the Jurassic Long Lake plutonic suite, and the Cretaceous Dawson Range batholith (Figure 1.2.2).

The Yukon-Tanana terrane underwent episodic metamorphism between the Mississippian and the Lower Cretaceous, which is poorly constrained as a result of few modern metamorphic and geochronological studies being conducted in the area (Dusel-Bacon et al., 1995; Berman et al., 2007; Staples et al., 2013; 2014; Clark et al., 2016). Lack of high T closure metamorphic mineral phases such as monazite, allanite, zircon, etc. that are suitable for dating, and the high variance metamorphic mineral assemblages, preclude 
establishment of good constraints on peak P-T-t conditions. The Stewart River area

contains extensive amphibolite grade exposures of metasedimentary rocks and

amphibolite, but with limited occurrences of garnet-bearing metapelitic to metapsammitic

rocks. Other key amphibolite facies index minerals such as kyanite or staurolite are rarely

observed in the area, limiting the potential identification of precise peak metamorphic

conditions.

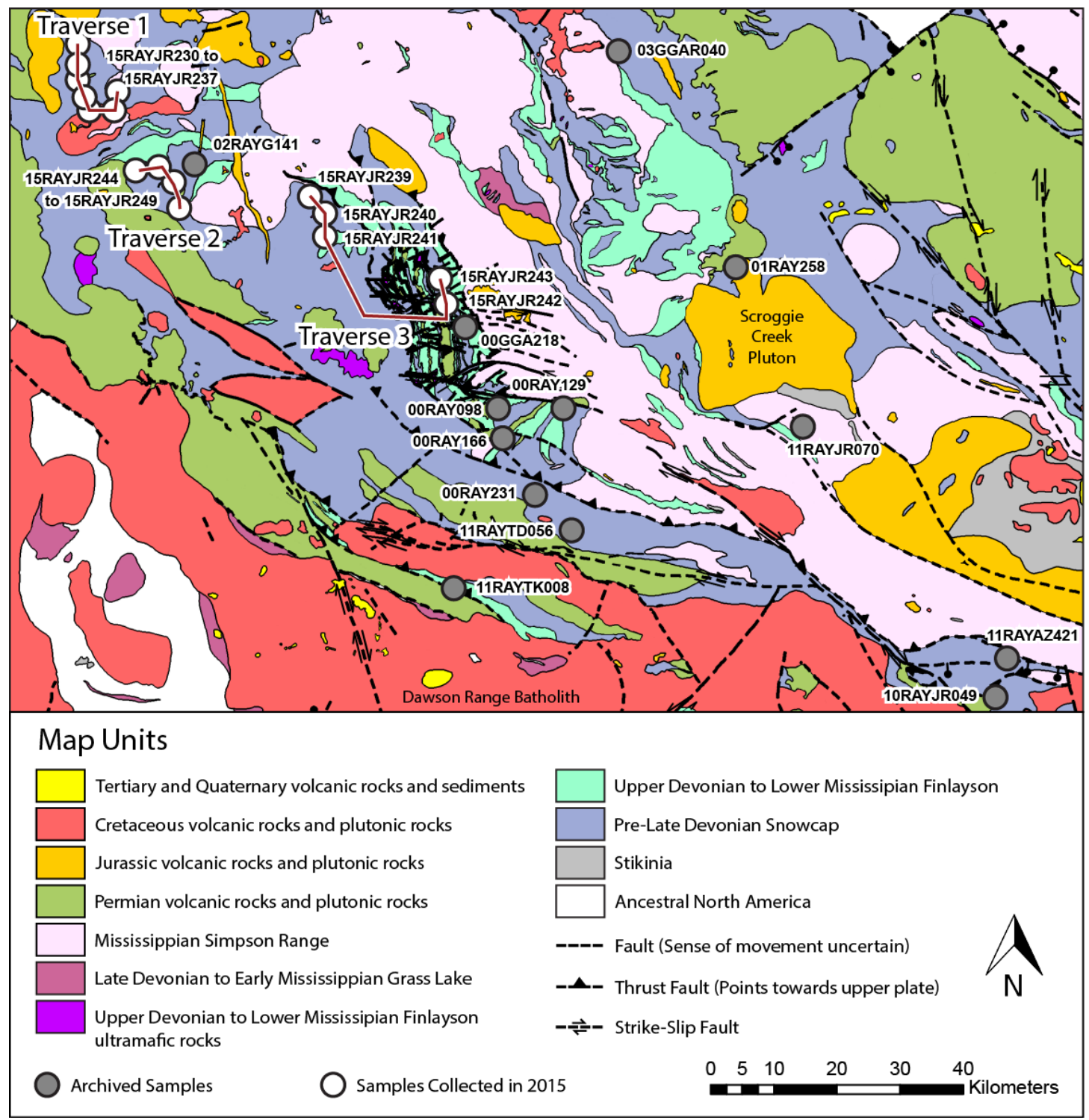

Figure 1.2.2 Geological map of the study area with sample location. Modified after Gordey and

Ryan (2005) and Colpron and Nelson (2011). 
Three regionally extensive metamorphic episodes are recognized in the Stewart River area (Berman et al., 2007). The first occurred in the Lower Mississippian, the second in the Permian, and the third in the Lower Jurassic. The first metamorphic event is characterized by low-pressure metamorphism at 365-350 Ma (U-Pb titanite: Berman et al., 2007). This metamorphism has been attributed to either contact metamorphism associated with the emplacement of the Mississippian Simpson Range plutonic suite or related to shortening and thickening of the Yukon-Tanana terrane that was broadly coeval with arc magmatism (Berman et al., 2007).

The second regional metamorphic event reached peak conditions of $9 \mathrm{kbar}$ and $600{ }^{\circ} \mathrm{C}$ between 260 and $240 \mathrm{Ma}$ (U-Pb monazite: Berman et al., 2007). This event is thought to be related to either intra-arc thickening of the YTT during the closure of the Slide Mountain Ocean (Berman, 2007) or to thickening related to the collision of the YTT with North America following the closure of the Slide Mountain Ocean (Beranek and Mortensen, 2011). However, the link with crustal thickening is difficult to ascertain as this event also coincides with a period of major extension that culminated in exhumation of orogenic peridotite in the YTT (Canil et al., 2003; Johnston et al., 2007).

The third event peaked at $7.8 \mathrm{kbar}$ and $595^{\circ} \mathrm{C}$ at 195 to $187 \mathrm{Ma}$ (U-Pb monazite: Berman et al., 2007; Staples et al., 2014). Similar to M2, the cause of this event is poorly constrained. Nelson et al. (2013) attributed this event to the accretion of the YTT to Laurentia and corresponding arc plutonism associated with the closure of the Cache 
Creek Ocean. This model is in conflict with Beranek and Mortensen (2011), who proposed accretion of YTT to Laurentia during M2.

\subsection{Purpose of Study and Research Objectives}

The purpose of this study is to constrain the tectono-metamorphic history experienced by the Snowcap assemblage of the Stewart River area using new and archived (Gordey and Ryan, 2005) metapelitic to metapsammitic samples of the Snowcap assemblage. Relatively new techniques are used, including the numerical simulation of garnet crystallization coupled with garnet Lu-Hf geochronology to obtain precise P-T-t paths that characterize the metamorphism experienced in the area. These techniques provide an opportunity to integrate high variance assemblages that cannot be easily constrained using conventional thermobarometry with metamorphic crystallization ages. Objectives of the project include:

- Petrographic analysis of textural features to describe deformation and metamorphic history;

- Whole rock geochemical analyses, phase equilibrium modeling, $\mathrm{x}$-ray micro computed tomography, electron microprobe analyses, and garnet crystallization modeling to constrain P-T-t paths experienced by samples within the Stewart River area;

- Age-dating of the metamorphic events using Lu-Hf and Sm-Nd garnet geochronology;

- Comparison of findings to previous studies;

- Establishment of a model that compliments all results. 


\section{Chapter: Methods}

\subsection{Sample Collection}

Outcrops of garnet-bearing metapelitic to metapsammitic composition from the Snowcap Assemblage were targeted using the geodatabase of the area (Gordey and Ryan, 2005). Three days of fieldwork were focused on sample collection across the field area in August 2015. Two days consisted of traverses in the northwest part of the field area (Figure 1.2.2), and the third day consisted of five helicopter stops in the central part of the field area. Archived samples from the previous mapping project were also used to expand the sample pool and to cover a larger portion of the Stewart River area. New samples are labeled starting with the prefix ' 15 ' while archived samples are labeled with '00', '01', ' 02 ', '03', ' 10 ', or ' 11 ', each corresponding to the year of collection.

\subsection{Whole Rock Chemistry}

Approximately $200 \mathrm{~cm}^{3}$ of material for each sample was sent for lithogeochemical analyses at Activation Laboratories (Ancaster, Ontario). The samples were pulverized using an agate mill and then analyzed using x-ray fluorescence (XRF) for the major elements, inductively coupled plasma optical emission spectrometry (ICP-OES) for minor elements, titration for the $\mathrm{FeO}$ and $\mathrm{Fe}_{2} \mathrm{O}_{3}$ contents, and combustion analysis for the $\mathrm{C}$ and $\mathrm{S}$ contents.

\subsubsection{X-Ray Fluorescence}

Sample powders were heated at $1000^{\circ} \mathrm{C}$ for 2 hours, and then weighed to measure the Loss on Ignition (LOI). Approximately $0.75 \mathrm{~g}$ of the homogenized sample was fused in 
Pt crucibles with $9.75 \mathrm{~g}$ of lithium metaborate and lithium tetraborate and the resultant was poured in Pt molds. Lithium bromide was used as a releasing agent. Major elements were measured using a Panalytical Axios Advanced wavelength dispersive x-ray fluorescence (XRF) analyzer using the method of Norrish and Hutton (1969). The detection limit was 0.001 wt.\% for $\mathrm{MnO}, 0.003$ wt.\% for $\mathrm{NiO}$ and $\mathrm{V}_{2} \mathrm{O}_{5}$, and 0.01 wt.\% for all other compounds.

\subsubsection{Inductively Coupled Plasma Optical Emission Spectrometry}

Samples were mixed in an induction furnace with lithium metaborate and lithium tetraborate. The resulting melt was completely dissolved in 5\% nitric acid. Trace elements and oxides were measured with a Varian Vista 735 inductively coupled plasma optical emission spectrometer (ICP-OES). The detection limit for $\mathrm{Mn}$ and $\mathrm{TiO}_{2}$ was 0.001 wt.\%, and 0.01 wt.\% for all other oxides. For trace elements, the detection limit was 5 ppm for $\mathrm{V}, 2 \mathrm{ppm}$ for $\mathrm{Ba}, \mathrm{Sr}$, and $\mathrm{Zr}$, and $1 \mathrm{ppm}$ for $\mathrm{Y}, \mathrm{Sc}$, and $\mathrm{Be}$.

\subsubsection{Fe-Titration}

Titration analysis was used to measure $\mathrm{FeO}$ and $\mathrm{Fe}_{2} \mathrm{O}_{3}$ contents. Silicates and sulphides were dissolved with a complete cold acid digestion using ammonium metavanadate and hydrofluoric acid. Ferrous ammonium sulphate was added after the digestion with a potassium dichromate titrating agent. The detection limit of the $\mathrm{FeO}$ concentration was $0.1 \%$. 


\subsubsection{Combustion Analysis}

Carbon and sulfur contents of each sample were determined using combustion analysis with an Eltra CS-800 carbon-sulfur analyzer. $0.2 \mathrm{~g}$ of each sample was mixed with accelerator material and put into an induction furnace, causing the samples to combust. Carbon and sulphur were released from carbon-bearing and sulphur-bearing particles and reacted to form carbon dioxide and sulphur dioxide. The resultant gas was measured by infrared cells as $\mathrm{CO}_{2}$ and $\mathrm{SO}_{2}$ emit different wavelengths within the IR spectrum. The minimum detection limit is $0.01 \%$.

\subsection{Petrography}

Initial thin sections perpendicular to the rock foliation with a thickness of $30 \mu \mathrm{m}$ were prepared for each sample at Vancouver Petrographics. All thin sections were examined for their mineralogy and textures using a Zeiss transmitted light microscope. Samples containing representative mineral assemblages that contain no indications of significant alteration were imaged by x-ray micro computed tomography (see following). The results of x-ray micro computed tomography were used to identify the largest garnet crystals and to constrain the best orientation for secondary thin sections that were prepared at Carleton University. These sections were prepared specifically to cross the center of identified garnet crystals at a resolution of $\pm 30 \mu \mathrm{m}$.

\subsection{X-Ray Micro Computed Tomography}

Seven samples were scanned using a high-resolution x-ray micro computed tomography $(\mathrm{XR}-\mu \mathrm{CT})$ scanner. Samples were selected using their mineral assemblages, 
geochemistry, textures, and their collection localities. Selection was made in attempt to cover each general area on the field area map (figure 1.2.2). Samples with euhedral to subhedral garnets and lowest $\mathrm{MnO}$ whole-rock concentration were prioritized. The selected samples include 00RAY098A, 00RAY231A, 10RAYJR249A1, 11RAYJR070A1, 15RAYJR237B1, 15RAYJR241A1, and 15RAYJR246A1. Volumes of rock of approximately $30 \mathrm{~cm}^{3}$ were scanned with a SkyScan 1173 scanner at Carleton University. The x-ray source used was $130 \mathrm{kV}$ and $61 \mu \mathrm{A}$. All samples were scanned at rotation steps of $0.3^{\circ}$ for $180^{\circ}$ in total. A brass filter was used to reduce the beam hardening effect (Jennings, 1988). Resulting x-ray images were transferred to cross section images using the SkyScan NRecon software. 3D visualization software BLOB3D (Ketcham, 2005), and Avizo were used to quantify the 3D textures of garnet in all samples. BLOB3D was used to identify and separate individual garnet grains. Location in the sample, volume and surface area information about each garnet crystal were extracted. Radii of crystals were calculated assuming a spherical shape of garnet. Garnet crystal size distribution was measured and the largest garnet crystal in each sample was identified. The largest crystals were centrally cut along their long axes to obtain a garnet cross-section that cuts through their geometric center, at a resolution of $\pm 30 \mu \mathrm{m}$, in order to acquire the best representative garnet compositional profile. Samples that contained distinct variations in crystal size distribution for different areas in the rocks (e.g. one side of the sample contains large garnet crystals, while the other side only contains smaller crystals) had thin sections made crossing the largest garnet crystal in each respective section for comparison. 


\subsection{Electron Microprobe Analysis}

A transect was analyzed across the largest garnet of each of the 7 samples scanned with $\mathrm{XR}-\mu \mathrm{CT}$. For samples with an inhomogeneous garnet size distribution, a transect was analyzed across the largest garnet of each group within a sample. The spacing of spot analyses varied between 20 and $80 \mu \mathrm{m}$, depending on the size of the garnet crystal analyzed, resulting in between 51 and 134 analyses for each garnet. The analyses were done using a Cameca Camebax MBX electron probe micro analyzer at Carleton University. The accelerating potential was $20 \mathrm{kV}$, and the beam current was $20 \mathrm{nA}$. The peak counting times were either 40,000 counts or 15-25 seconds for all elements. Counts were converted into weight $\%$ using the Cameca PAP matrix correction software. A combination of natural and synthetic minerals and compounds were used as standards (Table 2.5.1). Measurements were done with an accuracy of $\pm 1-2 \%$ relative for major elements, and $\pm 3-10 \%$ relative for minor elements. The relative error approaches $100 \%$ as the detection limit is approached. The detection limit for major elements is $0.01 \mathrm{wt} . \%$, and 0.02 wt. $\%$ for trace elements.

Compositional profiles of garnet were calculated using the mole fraction of $\mathrm{Fe}, \mathrm{Mg}, \mathrm{Ca}$, and $\mathrm{Mn}$, where $\mathrm{xFe}, \mathrm{xMg}, \mathrm{xCa}$, and $\mathrm{xMn}$ are measured in the following format:

$$
x F e=\frac{F e^{2+}}{F e^{2+}+M g+C a+M n}
$$

Analyses were done on all other major mineral phases to obtain their chemical compositions, and on mineral inclusions in garnet. 
Table 2.5.1 EMPA standards.

\begin{tabular}{|c|c|}
\hline Element & Standard \\
\hline $\mathrm{Si}, \mathrm{Mg}$ & Olivine, natural \\
\hline $\mathrm{Al}$ & Spinel, synthetic \\
\hline $\mathrm{Na}$ & Albite, natural \\
\hline $\mathrm{K}$ & Microcline, United States Natural Museum \\
\hline $\mathrm{Ca}$ & Wollastonite, natural \\
\hline $\mathrm{Ti}$ & $\mathrm{MnTiO}_{3}$, synthetic \\
\hline $\mathrm{Cr}$ & $\mathrm{Cr}_{2} \mathrm{O}_{3}$, synthetic \\
\hline $\mathrm{Mn}$ & $\mathrm{MnTiO}_{3}$, synthetic \\
\hline $\mathrm{Fe}$ & Fayalite, synthetic \\
\hline $\mathrm{Ni}$ & $\mathrm{NiO}$, synthetic \\
\hline $\mathrm{Ba}$ & Barite, natural \\
\hline $\mathrm{Y}$ & $\mathrm{Y}_{3} \mathrm{Al}_{5} \mathrm{O}_{12}$, synthetic \\
\hline $\mathrm{Cl}$ & Tugtupite, natural \\
\hline $\bar{F}$ & Lithium fluoride, synthetic \\
\hline
\end{tabular}

\subsection{Scanning Electron Microscope}

Four samples were imaged through a Tescan Mira3 field emission scanning electron microscope (SEM) for the identification of age-dating targets such as monazite, allanite, rutile or zircon. Images were captured using a backscattered electron detector (BSE) and a cathodoluminescence detector (CL). Measurements were done using the Oxford energy dispersive spectrometry (EDS) system, including the X-MAX 80 silicon drift detector with the AZtec Energy 3.2 microanalysis software. Sections were held at a working distance of $15 \mathrm{~mm}$ and were analyzed using a $20 \mathrm{kV}$ source with a current of $400 \mathrm{pA}$ to 1 nA. Entire thin sections were scanned using an automated AZtec feature that identifies and lists minerals. Results were individually observed for dating potential. 


\subsection{Thermodynamic and Kinetic Modeling}

\subsubsection{Metamorphic Phase Equilibria}

Phase equilibria were modeled using the DOMINO software v.01.03.2011 (de Capitani and Petrakakis, 2010) and the whole rock chemistry for each sample. The models were obtained for a $\mathrm{MnO}-\mathrm{Na}_{2} \mathrm{O}-\mathrm{CaO}-\mathrm{K}_{2} \mathrm{O}-\mathrm{FeO}-\mathrm{MgO}-\mathrm{Al}_{2} \mathrm{O}_{3}-\mathrm{SiO}_{2}-\mathrm{H}_{2} \mathrm{O}-\mathrm{TiO}_{2}$ system using the thermodynamic database from Holland and Powell (1998), modified with updated data for garnet, feldspar, chlorite, biotite, muscovite and fluids. Garnet properties with a Mn, $\mathrm{Fe}, \mathrm{Mg}$, and $\mathrm{Ca}$ end-member solution were taken from the PerpleX model (Connolly, 2005), feldspar properties from Baldwin et al. (2005), biotite properties from White et al. (2005), chlorite from Gaidies et al. (2008), and white mica from Coggon and Holland (2002). This modified thermodynamic database was used for all modeling. Equilibrium assemblage diagrams, garnet volume percentages, and garnet isopleths for almandine, pyrope, grossular and spessartine, were calculated for a range of 350 to $650{ }^{\circ} \mathrm{C}$ and 2 to $10 \mathrm{kbar}$ for all samples. The garnet core isopleth intersections were plotted for samples analyzed with the electron microprobe.

\subsubsection{Garnet Crystallization}

Garnet crystallization modeling was done using the forward modeling software THERIA_G (Gaidies et al., 2008) on samples that have been scanned with XR- $\mu C T$ and EMPA. The thermodynamic database used for phase equilibrium modeling was also used for this method. The sample whole rock chemistry and garnet size classes representing the garnet CSD were specified in the input files. The CSD was divided into 20 size classes of equal size ranges containing respective amounts of garnet crystals per $\mathrm{cm}^{3} . \mathrm{A}$ 
P-T-t path was defined using garnet-isopleth thermobarometry (Gaidies et al., 2006) applied to the core of the largest garnet crystal as a starting point, as it represents the composition of the first garnet crystal to have crystallized in the bulk chemistry measured. The P-T-t path was modified to best match the garnet compositional profiles observed. The grossular profiles were used as primary guidelines as they are least affected by diffusion (Florence and Spear, 1991).

Diffusion modeling was then conducted by modeling garnet crystallization under various heating rates and with dwell periods near peak conditions (e.g. at $\mathrm{T} \geq 580^{\circ} \mathrm{C}$ ) to obtain observed diffusional relaxation levels. Spessartine and almandine compositional profiles were used as guidelines for the diffusion simulations as they are the fastest to diffuse.

\subsection{Lu-Hf and Sm-Nd Geochronology of Garnet}

$\mathrm{Lu} / \mathrm{Hf}$ dating of garnet was done at the Institute of Geological Sciences, Polish Academy of Sciences Research Center in Kraków, Poland. Sulphuric acid leaching (SAL) and sample digestion was conducted to remove phosphate inclusions (Anczkiewicz et al., 2003). All leaching and rinsing steps were conducted in an ultrasonic bath. First, samples were leached with $40 \% \mathrm{HF}$ at $60{ }^{\circ} \mathrm{C}$ for 2 hours. Samples were then rinsed with $\mathrm{H}_{2} \mathrm{O}$ for 15 minutes. Samples were leached again using $6 \mathrm{M} \mathrm{HCl}$ for 30 minutes at $60{ }^{\circ} \mathrm{C}$, and rinsed with $\mathrm{H}_{2} \mathrm{O}$ for 15 minutes.

Mineral fractions were dissolved in Teflon beakers on a hotplate. Mineral separates were spiked with a 3:1 $\mathrm{HF}-\mathrm{HNO}_{3}$ mixture for 1-2 days at temperatures of 120 to $160{ }^{\circ} \mathrm{C}$. 
Samples were evaporated dry and then treated with three doses of $150-250 \mu l$ of $\mathrm{HNO}_{3}$, followed by a treatment of $2-6 \mathrm{ml}$ of $6 \mathrm{~N} \mathrm{HCl}: 0.1 \mathrm{~N} \mathrm{HF}$ for 24 hours at $120-160{ }^{\circ} \mathrm{C}$ on a hotplate. Dissolved samples were dried and treated twice with $1 \mathrm{ml}$ of $6 \mathrm{~N} \mathrm{HCl}$.

$\mathrm{Hf}, \mathrm{Lu}, \mathrm{Yb}$ and LREE fractions were separated on a cation exchange column with a AG50W-X8 resin and a 200-400 mesh size (Patchett and Tatsumoto, 1980). Alternating $6 \mathrm{~N} \mathrm{HCl}$ and $6 \mathrm{~N} \mathrm{HCl}: 1 \mathrm{~N} \mathrm{HF}$ were used for cleaning. A last Hf purification step was done on a Ln-spec column to remove $\mathrm{Lu}$ and $\mathrm{Yb}$ interferences (Lee et al., 1999; Anczkiewicz et al., 2004). Separation of Sm and Nd was done on a smaller Ln-spec column (Pin and Santos-Zaldegui, 1997).

Lu-Hf and Sm-Nd isotope contents were measured using a Neptune Multicollector Inductively Coupled Plasma Mass Spectrometer (MC ICP-MS). Ages, initial ${ }^{176} \mathrm{Hf} /{ }^{177} \mathrm{Hf}$ ratios, MSWD and isochron diagrams are calculated using Isoplot 4.15 (Ludwig, 2008). Errors are reported with a 95\% confidence level. 


\section{Chapter: Results}

Results for sample description described below follow the NW-SE geographic order and distribution. Samples from the NW are addressed first, and samples from the SE are addressed last.

\subsection{Sample Collection}

19 samples were collected during the summer of 2015, and an additional 17 samples were selected from the GSC archived samples. Coordinates of all sample collection sites can be found in table 3.1.1.

Table 3.1.1 Sample location coordinates and corresponding locality. All coordinates are under the NAD83 system.

\begin{tabular}{|l|l|l|l|l|l|l|c|}
\hline \multicolumn{1}{|c|}{ Sample \# } & Latitude & Longitude & Locality & \multicolumn{1}{|c|}{ Sample \# } & Latitude & Longitude & Locality \\
\hline 15RAYJR230A & 63.4379 & -140.3335 & NW & 15RAYJR239A & 63.2784 & -139.7116 & Central \\
\hline 15RAYJR231A & 63.4322 & -140.3319 & NW & 15RAYJR240A & 63.2690 & -139.7044 & Central \\
\hline 15RAYJR232A1 & 63.4290 & -140.3329 & NW & 15RAYJR241A & 63.2532 & -139.6959 & Central \\
\hline 15RAYJR232A2 & 63.4290 & -140.3329 & NW & 15RAYJR243A & 63.1863 & -139.3840 & Central \\
\hline 15RAYJR233A & 63.4233 & -140.3281 & NW & 15RAYJR242A & 63.1610 & -139.3687 & Central \\
\hline 02RAY080A & 63.4132 & -140.3250 & NW & 15RAYJR242B & 63.1610 & -139.3687 & Central \\
\hline 15RAYJR235A & 63.4060 & -140.3245 & NW & 00GGA218A & 63.1260 & -139.3177 & Central \\
\hline 15RAYJR236B1 & 63.3982 & -140.2963 & NW & 00RAY098A & 63.0248 & -139.2290 & Central \\
\hline 15RAYJR236B2 & 63.3982 & -140.2963 & NW & 00RAY166A & 62.9875 & -139.2231 & Central \\
\hline 15RAYJR237B & 63.4082 & -140.2778 & NW & 00RAY129A & 63.0224 & -139.0540 & Central \\
\hline 15RAYJR244A1 & 63.3301 & -140.1628 & NW & 00RAY231A & 62.9201 & -139.1396 & Central \\
\hline 15RAYJR244A2 & 63.3301 & -140.1628 & NW & 11RAYTD056A & 62.8730 & -139.0419 & Central \\
\hline 15RAYJR245A & 63.3291 & -140.1539 & NW & 11RAYTK008 & 62.8045 & -139.3619 & Central \\
\hline 15RAYJR246A & 63.3270 & -140.1329 & NW & 03GGAR040A & 63.4609 & -138.8745 & Other \\
\hline 02RAYG039C & 63.3276 & -140.1332 & NW & 01RAY258A & 63.1905 & -138.5739 & Scroggie Creek \\
\hline 02RAYG141A & 63.3608 & -140.0566 & NW & 11RAYJR070A & 62.9905 & -138.4140 & Scroggie Creek \\
\hline 15RAYJR248A & 63.3246 & -140.1211 & NW & 11RAYAZ421 & 62.6938 & -137.8899 & Other \\
\hline 15RAYJR249A & 63.3164 & -140.1080 & NW & 10RAYJR049A & 62.6459 & -137.9216 & Other \\
\hline
\end{tabular}


The samples used in this study are only representative of garnet-bearing metapelitic to metapsammitic rocks of the Snowcap Assemblage, while the majority of metapelitic and metapsammitic rocks do not contain garnet. Additionally, the Snowcap Assemblage contains quartzites, amphibolites, calc-silicates and marbles.

\subsection{Petrography}

\subsubsection{Mineralogy and Microstructures}

All samples studied contain garnet, white mica, quartz and biotite, with the occurrence of plagioclase, rutile and ilmenite in most samples, and the occasional presence of chlorite, staurolite, kyanite, magnetite, calcite, apatite, tourmaline, epidote, zoisite, and clinozoisite (Table 3.2.1). Their compositions vary between metapelite and metapsammite depending on their total quartz contents. Samples are divided into three aerially defined zones with distinctive differences in mineralogy and textures. 
Table 3.2.1 Sample mineralogy. Wmca - White Mica, Qtz - Quartz, Grt - Garnet, Bt - Biotite,

Plg - Plagioclase, Rt - Rutile, Ilm - Ilmenite, Ap - Apatite, Chl - Chlorite, Mg - Magnetite, Tur -

Tourmaline, Ep - Epidote, St - Staurolite, Ky - Kyanite, Cal - Calcite, Zo - Zoisite, Py - Pyrite, * -

Retrograde mineral. Mineral abbreviations following Siivola and Schmid (2007).

\begin{tabular}{|c|c|c|c|}
\hline Sample \# & $\begin{array}{c}\text { Mineralogy } \\
(+\mathrm{Wmca}+\mathrm{Grt}+\mathrm{Qtz}+\mathrm{Bt})\end{array}$ & Sample \# & $\begin{array}{c}\text { Mineralogy } \\
(+\mathrm{Wmca}+\mathrm{Grt}+\mathrm{Qtz}+\mathrm{Bt})\end{array}$ \\
\hline 15RAYJR230A & Rt-Ilm-Chl* & 15RAYJR239A & Rt-Ilm-Tur-Ch1* \\
\hline 15RAYJR231A & Rt-Ilm-Chl* & 15RAYJR240A & Plg-Rt-Cal-Czo-Ilm \\
\hline 15RAYJR232A1 & Plg-Ilm-Zo-Chl* & 15RAYJR241A & Plg-Rt-Ilm-Tur \\
\hline 15RAYJR232A2 & Plg-Rt-Py-Ilm-Zo-Chl* & 15RAYJR243A & Ilm-Rt-Ep \\
\hline 15RAYJR233A & Plg-Ilm-Tur-Chl* & 15RAYJR242A & Plg-Rt \\
\hline 02RAY080A & Rt-Ilm-Chl* & 15RAYJR242B & Plg-Ilm \\
\hline 15RAYJR235A & Plg-Rt-Ch1* & 00GGA218A & Plg-Rt-Ilm-Ap-Chl* \\
\hline 15RAYJR236B1 & Plg-Rt-Ilm-Chl* & 00RAY098A & Plg-Rt-Ilm-Ap-Chl* \\
\hline 15RAYJR236B2 & Plg-Rt-Chl* & 00RAY166A & Plg-Rt-Cal-Ilm-Oxide-Chl* \\
\hline 15RAYJR237B & Ilm-Rt-Chl-Chl* & 00RAY129A & Plg-Mag-Chl-Ep-Ilm-Chl* \\
\hline 15RAYJR244A1 & Plg-Rt-Ilm-Chl* & 00RAY231A & Plg-Ilm-Cal-Chl* \\
\hline 15RAYJR244A2 & Plg-Rt-Ilm-Chl* & 11RAYTD056A & Plg-Rt-Ilm-Chl* \\
\hline 15RAYJR245A & Plg-Ilm-Rt-Chl* & 11RAYTK008 & Plg-Rt-Ilm-Chl* \\
\hline 15RAYJR246A & Plg-Rt-Ch1* & 03GGAR040A & Plg-Ilm-Tur \\
\hline 02RAYG039C & Plg-Rt-Ilm-Chl* & 01RAY258A & Plg-Rt-Ky-Ilm \\
\hline 02RAYG141A & Rt-Ilm-Chl-Chl* & 11RAYJR070A & Plg-Rt-Ky-Ilm \\
\hline 15RAYJR248A & Plg-Rt-Ilm-Chl* & 11RAYAZ421A & Plg-Rt-Ilm-St-Chl* \\
\hline 15RAYJR249A & Plg-Rt & 10RAYJR049A & Plg-Rt-Ilm-Chl-Chl* \\
\hline
\end{tabular}

\section{Northwest Samples}

Samples 15RAYJR230A to 15RAYJR249A in table 3.2.1, from the northwest portion of

the study area (Figure 1.2.2) are garnet-mica schists and psammites with a garnet + white mica + biotite + quartz \pm plagioclase \pm ilmenite \pm rutile mineralogy (Figure 3.2.1)

Tourmaline is locally observed in sample 15RAYJR233, zoisite in sample 15RAYJR232, and prograde chlorite in samples 15RAYJR237 and 02RAYG141. Retrograde chlorite commonly forms rims around garnet and replaces biotite (Figure 3.2.1a, d). Garnet porphyroblasts are subhedral to anhedral and range from 0.15 to $4 \mathrm{~mm}$ in diameter. All garnet crystals are wrapped by the foliation and contain complex quartz inclusion trails that suggest several episodes of deformation (Figure 3.2.1a, c). Three deformation episodes are recognized in samples 15RAYJR232A and 15RAYJR244A. $\mathrm{S}_{\mathrm{M}-1}$ and $\mathrm{S}_{\mathrm{M}-2}$ 
are characterized by quartz and ilmenite inclusion trails in garnet. $\mathrm{S}_{\mathrm{M}-2}$ forms the oldest foliation that is crenulated by spaced, nearly orthogonal $\mathrm{S}_{\mathrm{M}-1}$ crenulation cleavage. $\mathrm{S}_{\mathrm{M}-1}$ and $\mathrm{S}_{\mathrm{M}-2}$ have the same orientation in all garnet crystals (Figure 3.2.2), suggesting that garnet did not rotate during $\mathrm{D}_{\mathrm{M}-1}$ or $\mathrm{D}_{\mathrm{M}} . \mathrm{S}_{\mathrm{M}}$ mica-rich, transposition foliation wraps around garnet porphyroblasts. Garnet growth occurred following $\mathrm{D}_{\mathrm{M}-1}$ and $\mathrm{D}_{\mathrm{M}-2}$, and prior to $\mathrm{D}_{\mathrm{M}}$, suggesting that it is intertectonic.
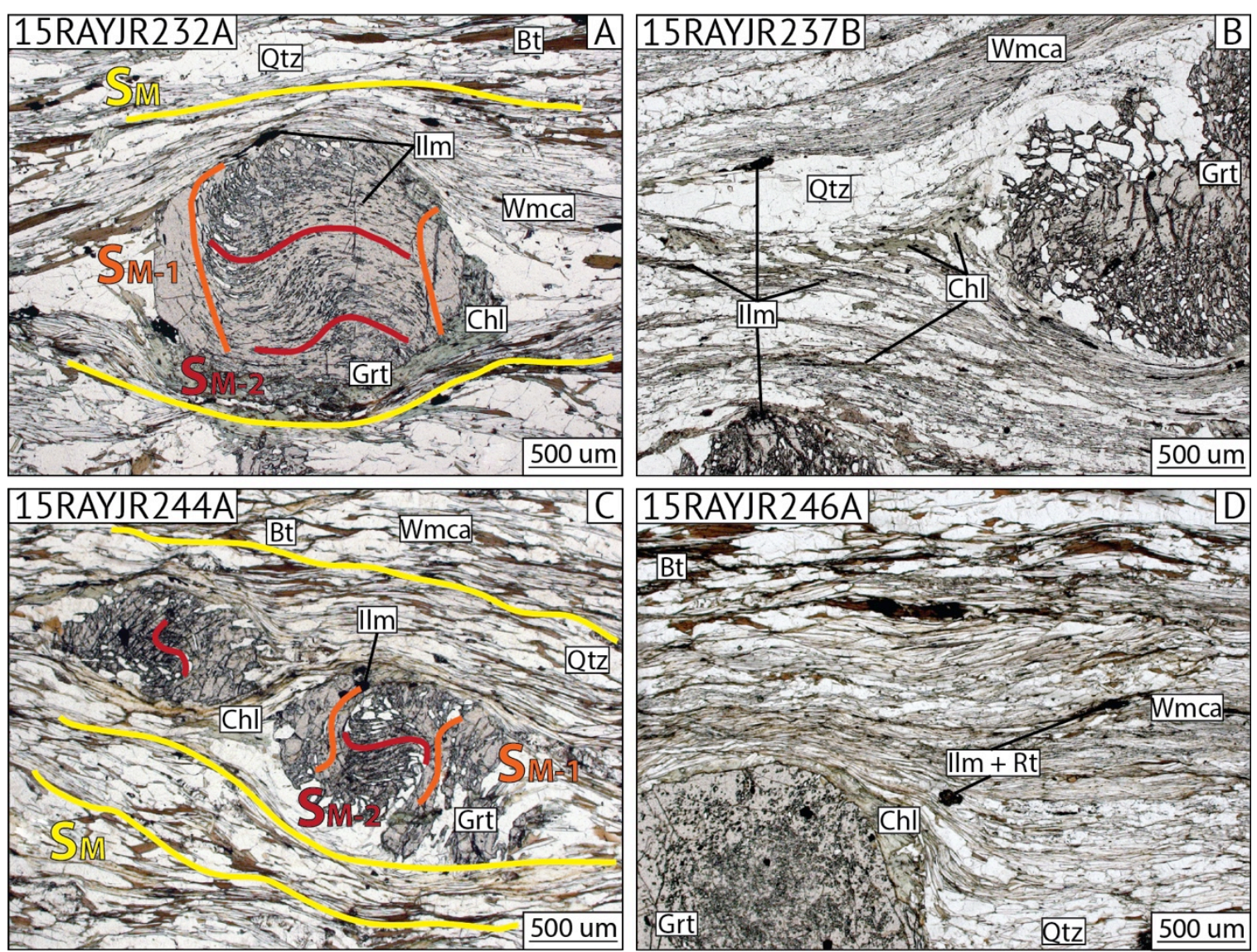

Figure 3.2.1 Thin section microphotographs of samples in the northwest part of the study area.

A) Sample 15RAYJR232A. B) Sample 15RAYJR237B. C) Sample 15RAYJR244A. D) Sample

15RAYJR246A. Structural observations are sketched labeled in figure 3.2.2 a and c. 




Figure 3.2.2 Thin section sketch of microstructures in samples 15RAYJR232A1 and

15RAYJR244A1. 


\section{Central Samples}

Samples 15RAYJR239A to 11RAYTK008 in table 3.2.1 were collected in the central part of the field area and consist of garnet + white mica + biotite + quartz \pm plagioclase \pm ilmenite \pm rutile and occasionally contain accessory minerals including apatite, tourmaline, calcite, magnetite, chlorite, epidote, zoisite, clinozoisite (Figure 3.2.3). Garnet forms subhedral to anhedral porphyroblasts that range widely in sizes from approximately 0.1 to $4 \mathrm{~mm}$ in diameter and are locally up to $8 \mathrm{~mm}$ in diameter. They contain quartz and ilmenite inclusions. Quartz inclusions are randomly oriented, but ilmenite inclusions form a $\mathrm{S}_{\mathrm{M}-2}$ foliation. Garnet growth occurred syn- to post-tectonic with respect to $S_{M-2}$, and pre-tectonic with respect to $S_{M}$, which forms a schistosity that wraps around garnet. Garnet crystals in sample 00RAY231A have strong textural boundaries separating cores from rims (Figure 3.2.3b), suggesting at least two episodes of metamorphism. Retrograde chlorite is common in the matrix. 

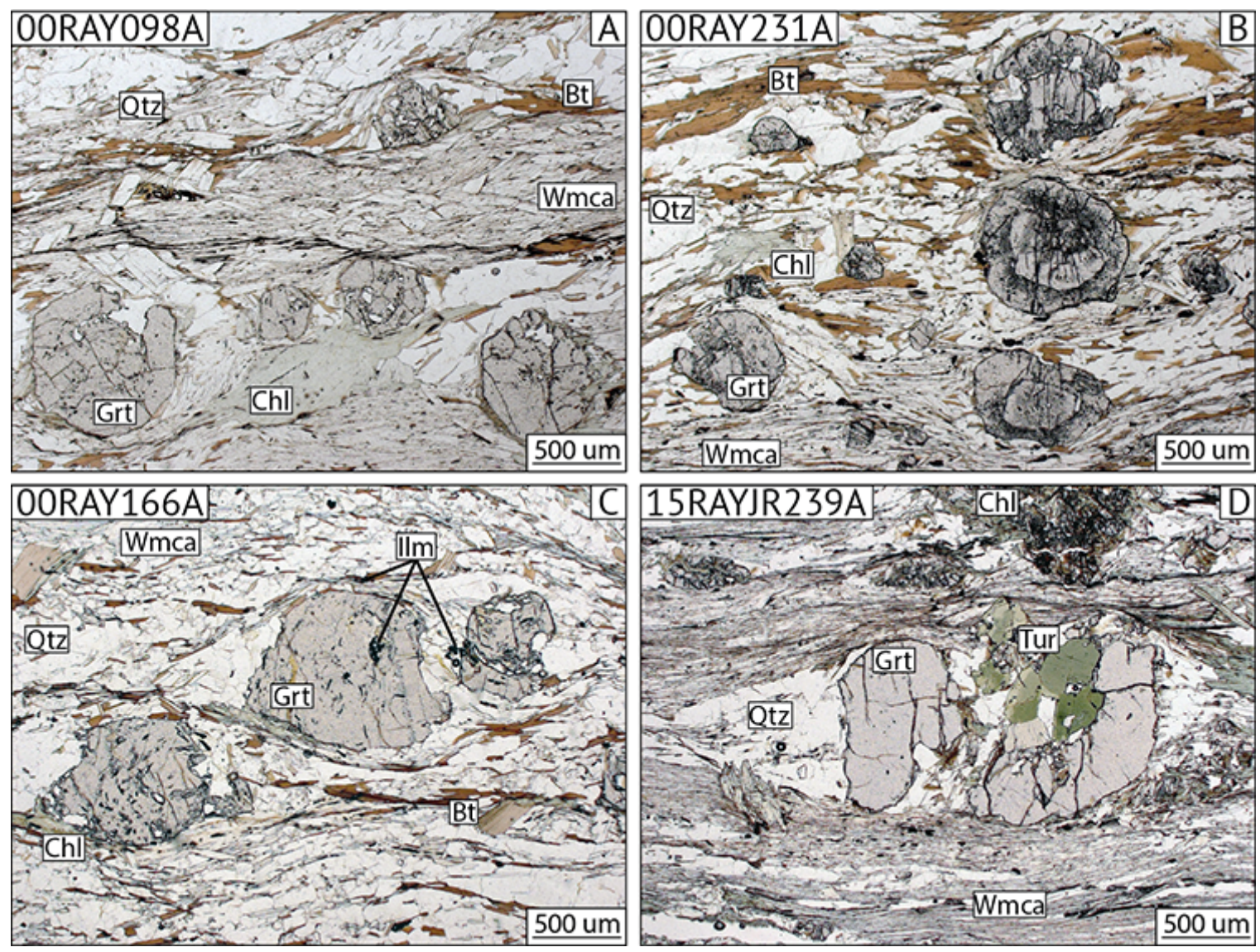

Figure 3.2.3 Thin section microphotographs of samples in the central part of the study area. A)

Sample 00RAY098A. B) Sample 00RAY231A. C) Sample 00RAY166A. D) Sample 15RAYJR239A.

\section{Scroggie Creek Samples}

Samples 01RAY258A and 11RAYJR070A are located adjacent to the Jurassic Scroggie Creek pluton. These two samples are coarse grained and have a mineralogy consisting of garnet + white mica + quartz + biotite + kyanite + plagioclase + rutile + ilmenite $($ Figure 3.2.4). Garnet porphyroblasts range between 0.5 and $10 \mathrm{~mm}$ in diameter, and kyanite porphyroblasts are up to $20 \mathrm{~mm}$ in length. Abundant ilmenite inclusions can be observed in both garnet and kyanite, but form no inclusion trails or patterns. Garnet crystals are 
subhedral in sample 01RAY258A, and euhedral in sample 11RAYJR070A.

Porphyroblasts are wrapped by the $S_{M}$ mica foliation.
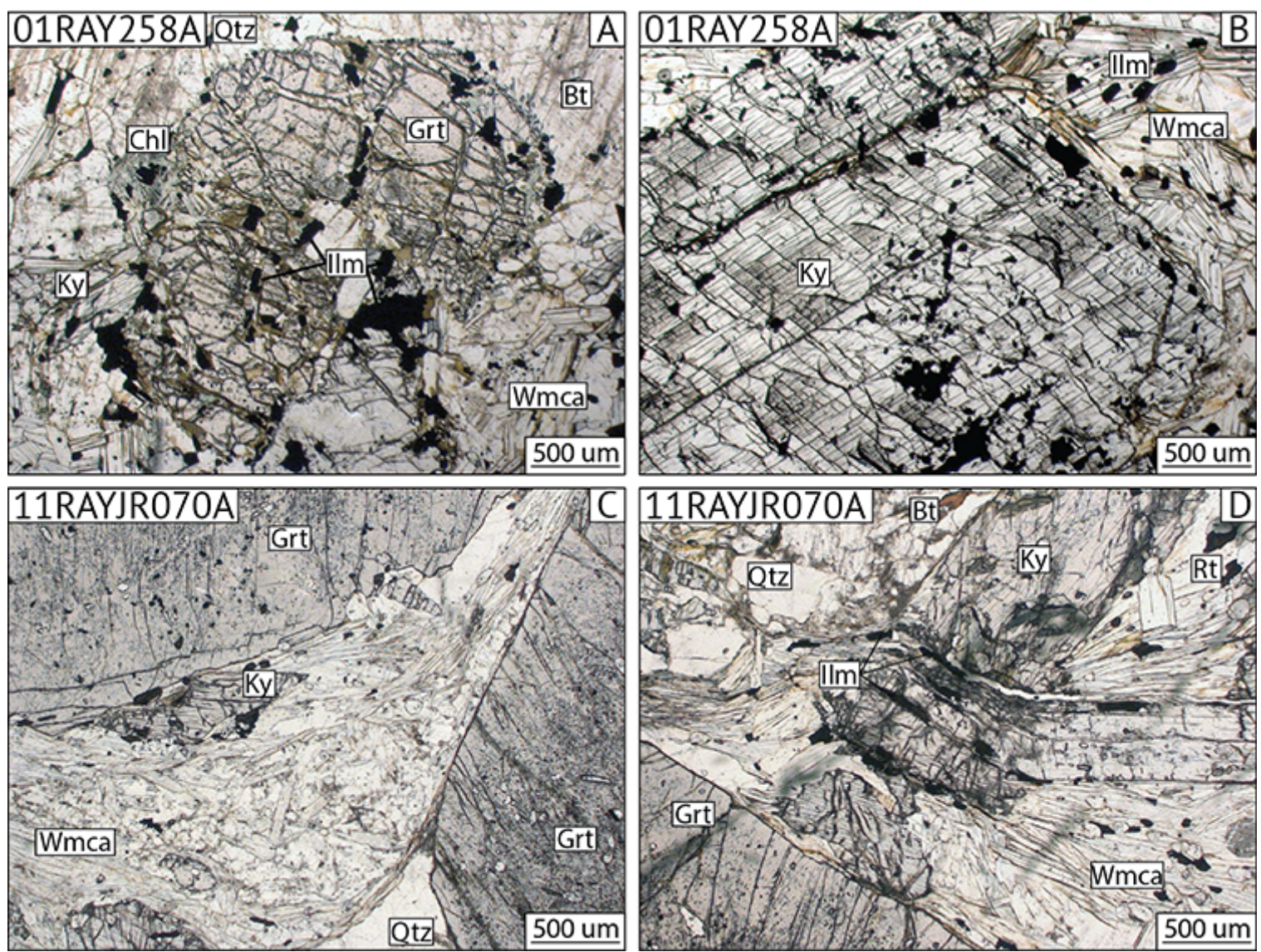

Figure 3.2.4 Thin section microphotographs of samples near the Scroggie Creek pluton. A, B)

Sample 01RAY258A. C, D) Sample 11RAYJR070A.

\section{Other Samples}

Samples 03GGAR040A, 11RAYAZ451, and 10RAYJR049A contain garnet

porphyroblasts which are wrapped by the foliation, but which do not contain inclusion

trail textures (Figures 3.2.5 and 1.2.2). Sample 03GGAR040A contains garnet + white

mica + quartz + biotite + tourmaline (Figure 3.2.5a). Tourmaline forms abundant crystals 
of up to $0.5 \mathrm{~mm}$ in diameter that are located throughout the sample. Garnet

porphyroblasts are wrapped by the foliation. Sample 10RAYJR049A contains garnet +

white mica + quartz + biotite + plagioclase + chlorite + ilmenite + rutile (Figure 3.2.5b)

Garnet crystals are subhedral to anhedral, inclusion-poor, and range from 0.1 to $1.5 \mathrm{~mm}$

in diameter. Sample 11RAYAZ421A contains garnet + white mica + quartz + biotite +

plagioclase + staurolite + ilmenite + rutile $($ Figure 3.2.5c, d). Garnet porphyroblasts are

anhedral and range from 0.1 to $3 \mathrm{~mm}$ in diameter. Retrograde chlorite forms rims around

garnet that can replace the entire crystal. Staurolite is scarce and is largely replaced by

white mica.
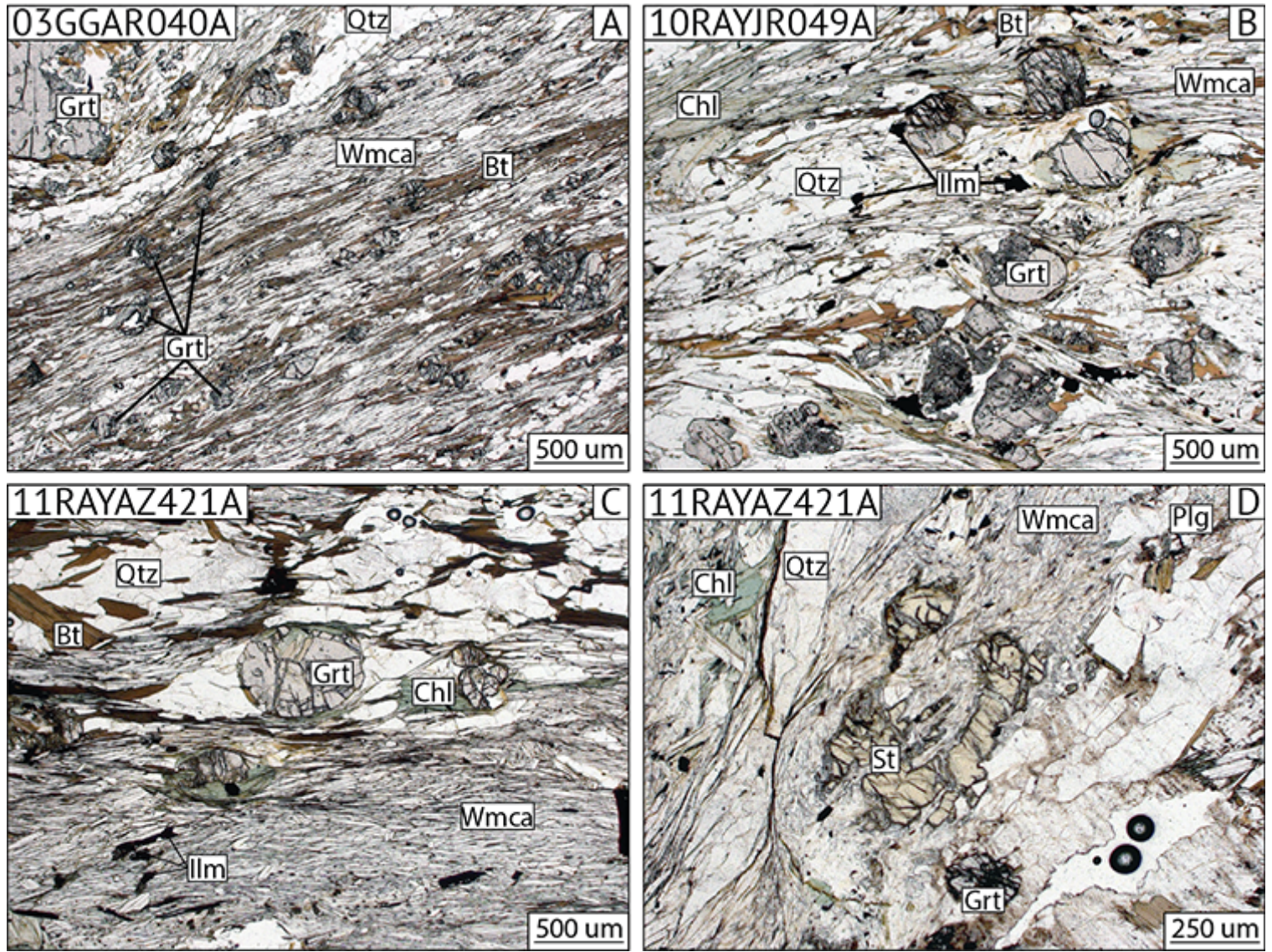
Figure 3.2.5 Thin section microphotographs of other samples. A) Sample 03GGAR040A, located to the N of the study area. B) Sample 10RAYJR049A, located SE of the field area. C, D) Sample 11RAYAZ421A, also located in the SE of the field area.

\subsection{Whole Rock Chemistry}

Whole rock major and trace element concentrations are presented in tables 3.3.1 and 3.3.2. Samples are categorized by the previously defined groups. With the exception of Scroggie Creek samples, other samples have similar geochemical compositions. Kyanitebearing Scroggie Creek samples are notable with varying $\mathrm{Al}_{2} \mathrm{O}_{3}$ contents of $25-36$ wt. \%, $\mathrm{SiO}_{2}$ contents of 41-48 wt.\%, and $\mathrm{Fe}_{2} \mathrm{O}_{3}$ contents of 11-14 wt.\%, relative to all other samples which contain 53-75 wt. $\% \mathrm{SiO}_{2}, 11-23$ wt. $\% \mathrm{Al}_{2} \mathrm{O}_{3}$, and 3-11 $\mathrm{Fe}_{2} \mathrm{O}_{3}$. 
Table 3.3.1 Major element whole rock compositions of all samples.

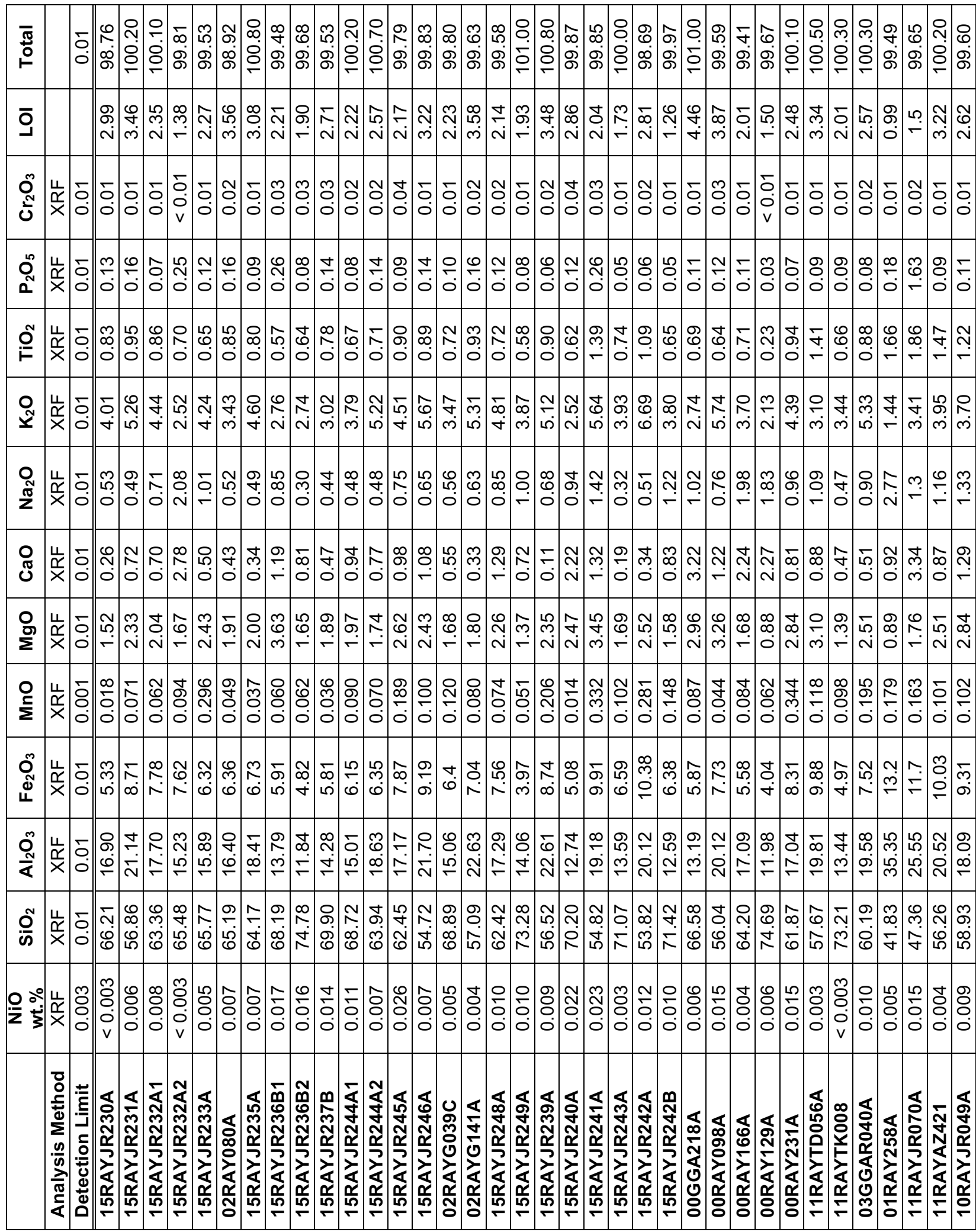


Table 3.3.2 Trace element compositions of all samples. The $100 \mathrm{TiO}_{2} / \mathrm{Zr}$ ratio is used to differentiate between pelite and psammite (Garcia et al., 1991).

\begin{tabular}{|c|c|c|c|c|c|c|c|c|c|c|c|}
\hline & $\mathrm{Ba}$ & $\mathrm{Sr}$ & $\mathbf{Y}$ & Sc & $\mathrm{Zr}$ & $\mathrm{Be}$ & $\mathbf{V}$ & C-Total & Total S & $\mathrm{FeO}$ & $100 \mathrm{TiO} / \mathrm{Zr}$ \\
\hline Unit Symbol & $\mathrm{ppm}$ & ppm & $\mathrm{ppm}$ & ppm & ppm & $\mathrm{ppm}$ & ppm & wt. $\%$ & wt. \% & wt. \% & \multirow{3}{*}{$\begin{array}{c}\text { Pelite } \\
\geq 0.4 \\
\text { Psammite } \\
<0.4\end{array}$} \\
\hline Detection Limit & 2 & 2 & 1 & 1 & 2 & 1 & 5 & 0.01 & 0.01 & 0.1 & \\
\hline $\begin{array}{l}\text { Analysis } \\
\text { Method }\end{array}$ & $\begin{array}{l}\text { ICP- } \\
\text { OES }\end{array}$ & $\begin{array}{l}\text { ICP- } \\
\text { OES }\end{array}$ & $\begin{array}{l}\text { ICP- } \\
\text { OES }\end{array}$ & $\begin{array}{l}\text { ICP- } \\
\text { OES }\end{array}$ & $\begin{array}{l}\text { ICP- } \\
\text { OES }\end{array}$ & $\begin{array}{l}\text { ICP- } \\
\text { OES }\end{array}$ & $\begin{array}{l}\text { ICP- } \\
\text { OES }\end{array}$ & CS & CS & TITR & \\
\hline 15RAYJR230A & 1461 & 46 & 33 & 16 & 272 & 3 & 126 & 0.01 & 0.02 & 2.8 & 0.31 \\
\hline 15RAYJR231A & 1395 & 73 & 27 & 20 & 202 & 3 & 103 & 0.02 & $<0.01$ & 6.5 & 0.47 \\
\hline 15RAYJR232A1 & 1237 & 85 & 23 & 18 & 158 & 3 & 103 & 0.01 & $<0.01$ & 6.2 & 0.54 \\
\hline 15RAYJR232A2 & 613 & 237 & 35 & 17 & 161 & 3 & 17 & $<0.01$ & 0.09 & 5.7 & 0.43 \\
\hline 15RAYJR233A & 671 & 119 & 26 & 14 & 154 & 3 & 73 & $<0.01$ & $<0.01$ & 4.7 & 0.42 \\
\hline 02RAY080A & 803 & 61 & 24 & 16 & 235 & 3 & 152 & 0.71 & 0.01 & 4.8 & 0.36 \\
\hline 15RAYJR235A & 1519 & 71 & 23 & 16 & 152 & 3 & 82 & 0.02 & $<0.01$ & 4.6 & 0.53 \\
\hline 15RAYJR236B1 & 1970 & 98 & 28 & 11 & 156 & 2 & 83 & $<0.01$ & $<0.01$ & 4.9 & 0.37 \\
\hline 15RAYJR236B2 & 1412 & 32 & 20 & 14 & 118 & 2 & 88 & 0.12 & $<0.01$ & 3.6 & 0.54 \\
\hline 15RAYJR237B & 819 & 61 & 17 & 13 & 236 & 2 & 120 & 0.41 & $<0.01$ & 5 & 0.33 \\
\hline 15RAYJR244A1 & 786 & 81 & 17 & 11 & 248 & 2 & 74 & 0.02 & $<0.01$ & 4.7 & 0.27 \\
\hline 15RAYJR244A2 & 1039 & 68 & 20 & 16 & 97 & 3 & 89 & 0.05 & $<0.01$ & 3.5 & 0.73 \\
\hline 15RAYJR245A & 930 & 103 & 18 & 18 & 170 & 3 & 94 & 0.02 & $<0.01$ & 5 & 0.53 \\
\hline 15RAYJR246A & 999 & 99 & 25 & 20 & 116 & 4 & 120 & 0.16 & $<0.01$ & 6.6 & 0.77 \\
\hline 02RAYG039C & 773 & 58 & 25 & 17 & 148 & 3 & 102 & 0.05 & $<0.01$ & 5.1 & 0.49 \\
\hline 02RAYG141A & 2588 & 93 & 30 & 22 & 215 & 4 & 194 & 0.12 & 0.03 & 5.5 & 0.43 \\
\hline 15RAYJR248A & 970 & 113 & 25 & 16 & 130 & 3 & 76 & 0.05 & $<0.01$ & 5.9 & 0.55 \\
\hline 15RAYJR249A & 715 & 106 & 20 & 9 & 297 & 3 & 62 & 0.06 & $<0.01$ & 2 & 0.20 \\
\hline 15RAYJR239A & 680 & 77 & 21 & 20 & 157 & 3 & 117 & 0.02 & $<0.01$ & 6.4 & 0.57 \\
\hline 15RAYJR240A & 2389 & 248 & 15 & 14 & 125 & 2 & 135 & 0.41 & $<0.01$ & 2.9 & 0.50 \\
\hline 15RAYJR241A & 1398 & 179 & 30 & 22 & 259 & 2 & 141 & 0.02 & $<0.01$ & 8.1 & 0.54 \\
\hline 15RAYJR243A & 933 & 86 & 26 & 15 & 344 & $<1$ & 76 & 0.01 & $<0.01$ & 4.4 & 0.22 \\
\hline 15RAYJR242A & 2820 & 82 & 24 & 28 & 199 & 1 & 124 & $<0.01$ & 0.04 & 7.2 & 0.55 \\
\hline 15RAYJR242B & 746 & 170 & 19 & 15 & 105 & 1 & 69 & 0.02 & $<0.01$ & 4.5 & 0.62 \\
\hline 00GGA218A & 756 & 217 & 24 & 12 & 264 & $<1$ & 74 & 0.91 & $<0.01$ & 5.1 & 0.26 \\
\hline 00RAY098A & 1074 & 85 & 21 & 17 & 135 & 3 & 85 & 0.34 & $<0.01$ & 6.6 & 0.48 \\
\hline 00RAY166A & 729 & 154 & 29 & 14 & 290 & 3 & 73 & 0.12 & $<0.01$ & 4.9 & 0.24 \\
\hline 00RAY129A & 652 & 72 & 39 & 14 & 150 & 1 & $<5$ & 0.11 & $<0.01$ & 2.4 & 0.15 \\
\hline 00RAY231A & 934 & 59 & 25 & 21 & 174 & 3 & 116 & 0.27 & 0.03 & 7.4 & 0.54 \\
\hline 11RAYTD056A & 633 & 191 & 28 & 25 & 235 & 4 & 162 & 0.06 & $<0.01$ & 8.9 & 0.60 \\
\hline 11RAYTK008 & 497 & 76 & 26 & 12 & 307 & 1 & 75 & 0.08 & $<0.01$ & 3.4 & 0.21 \\
\hline 03GGAR040A & 1106 & 58 & 22 & 20 & 224 & 3 & 113 & 0.03 & $<0.01$ & 6.3 & 0.39 \\
\hline 01RAY258A & 547 & 283 & 17 & 57 & 227 & 2 & 276 & 0.05 & 0.03 & 6.2 & 0.73 \\
\hline 11RAYJR070A & 2287 & 456 & 40 & 29 & 328 & 3 & 177 & 0.08 & $<0.01$ & 11.1 & 0.57 \\
\hline 11RAYAZ421 & 1052 & 183 & 33 & 22 & 359 & 2 & 140 & 0.03 & $<0.01$ & 7 & 0.41 \\
\hline 10RAYJR049A & 1060 & 142 & 31 & 20 & 251 & 3 & 139 & 0.06 & $<0.01$ & 7.7 & 0.49 \\
\hline
\end{tabular}

\subsubsection{AFM}

Samples plot as a trend pointing towards the ' $\mathrm{Al}_{2} \mathrm{O}_{3}-3 \mathrm{~K}_{2} \mathrm{O}$ ' apex, with the majority of samples plotting below the $50 \%$ mark of the ' $\mathrm{Al}_{2} \mathrm{O}_{3}-3 \mathrm{~K}_{2} \mathrm{O}$ ' apex, and samples

11RAYJR070A and 01RAY258A plotting above 50\% (Figure 3.3.1). All other samples plot within the same general area and have outcrop locations and mineralogical contents 
that are not associated with the observed trend. The samples contain higher FeO contents (being located between 35 and $70 \%$ from the 'FeO' apex) relative to the average metapelite (Symmes and Ferry, 1991). The MgO contents range approximately between 20 and 40\% from the 'MgO' apex. Snowcap assemblage metapelites and metapsammites analyzed by Piercey and Colpron (2009) plot in the same area with the same trend.

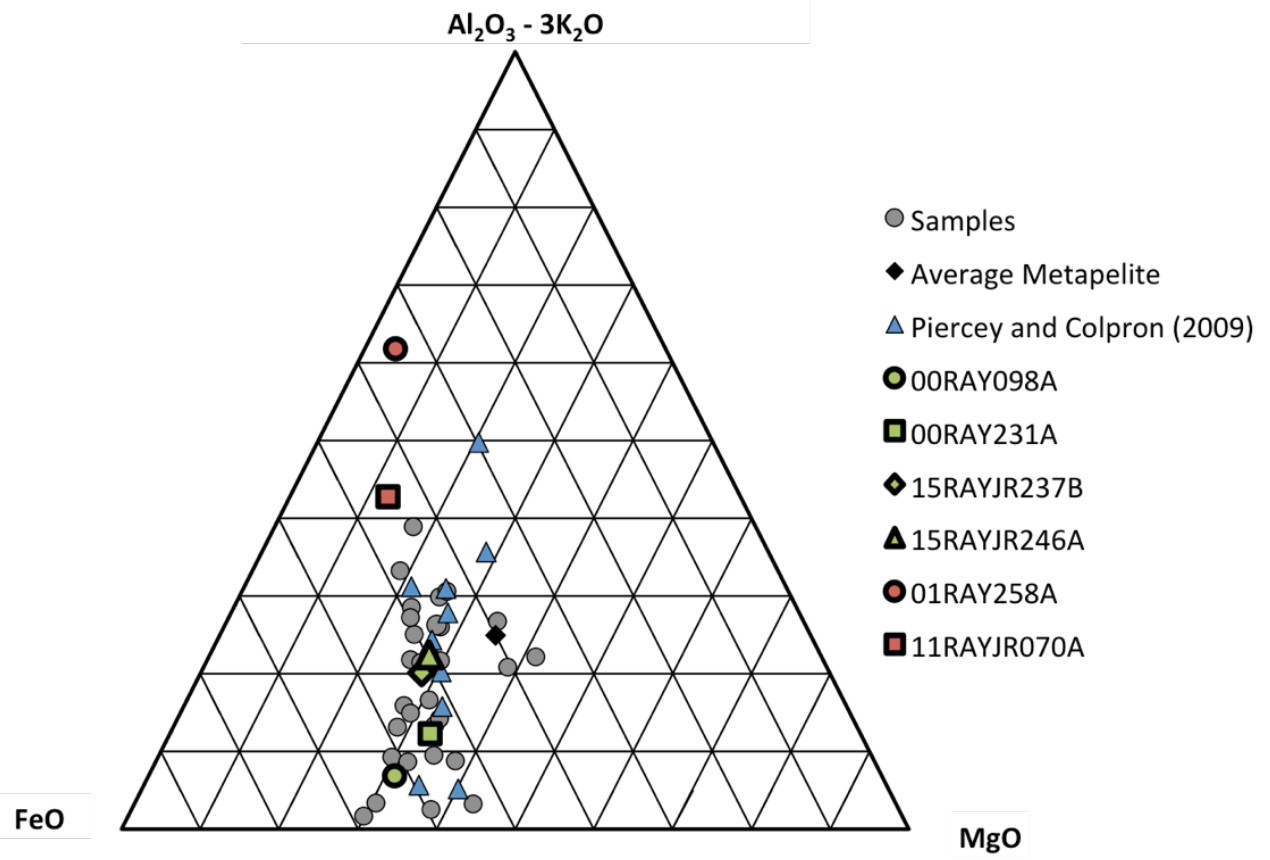

Figure 3.3.1 AFM diagram containing chemistry of all samples. The average metapelite composition is from Symmes and Ferry (1991).

\subsubsection{Provenance and Composition}

The Ti vs. Zr ratio can be used as an indicator of the sorting efficiency between pelitic and psammitic compositions due to the systematic and variable fractionation of $\mathrm{Ti}$ and $\mathrm{Zr}$ 
in shales and sandstones during sedimentation (Garcia et al., 1991). The $100 \mathrm{TiO}_{2} / \mathrm{Zr}$ ratio of pelites is $\geq 0.4$, and the ratio of psammites is $<0.4$. This ratio is calculated and displayed in table 3.3.2 and ranges between 0.15 and 0.77 , with the majority of samples being metapelites. $\log \left(\mathrm{Fe}_{2} \mathrm{O}_{3} / \mathrm{K}_{2} \mathrm{O}\right)$ vs. $\log \left(\mathrm{SiO}_{2} / \mathrm{Al}_{2} \mathrm{O}_{3}\right)$ is used to classify siliciclastic sedimentary rocks (Herron, 1988). Values measured suggest protoliths of shale and wacke compositions for samples of this study (Figure 3.3.2). Only pelitic samples plot within the shale field, while both pelitic and psammitic samples plot in the wacke field. Samples 11RAYJR070A and 01RAY258A plot away from all other samples in the shale and Fe-shale fields.

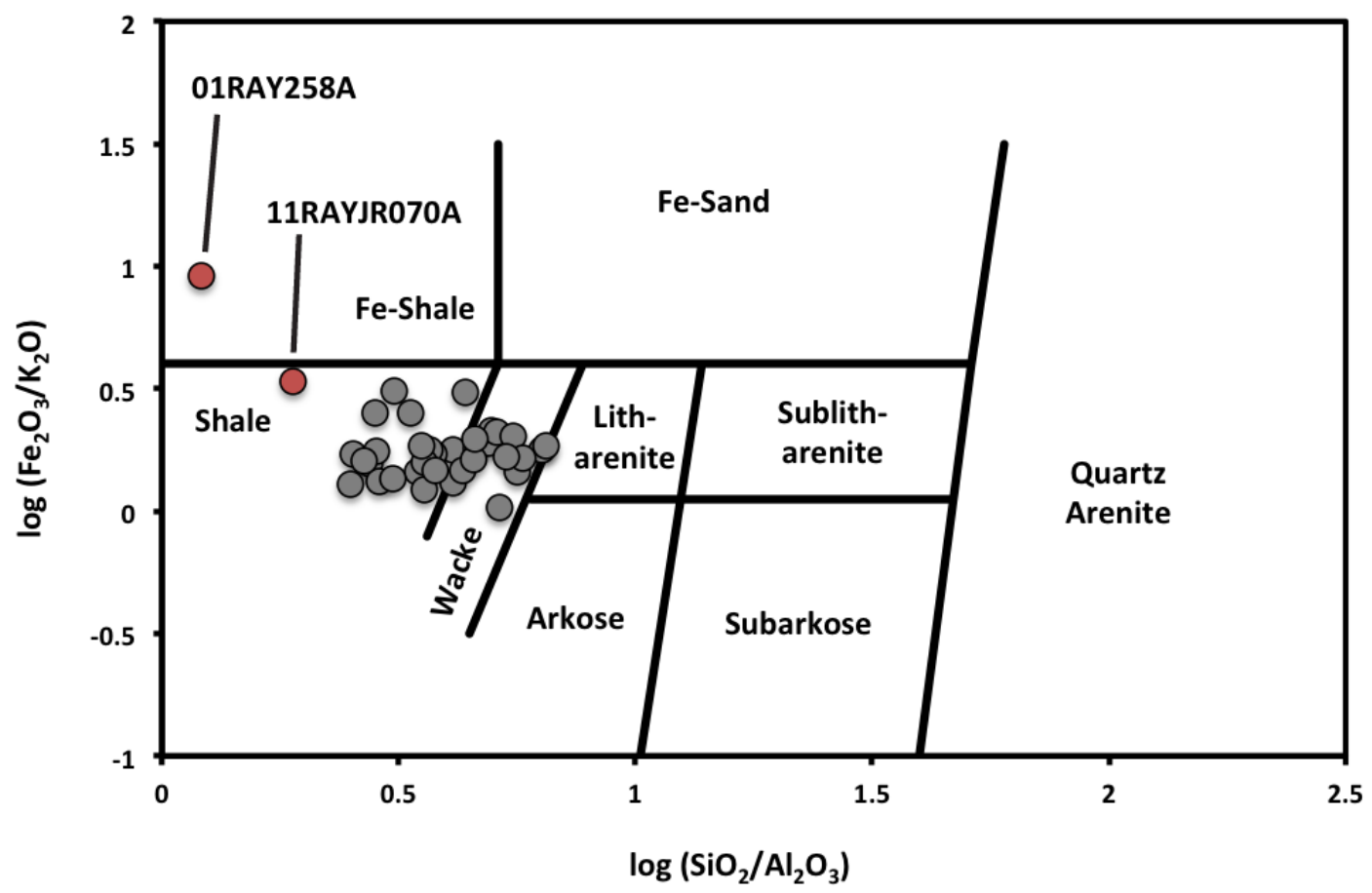

Figure 3.3.2 Sedimentary protolith diagram for metamorphosed rocks (modified from Herron, 1988). 
The $\mathrm{K}_{2} \mathrm{O} / \mathrm{Na}_{2} \mathrm{O}$ vs. $\mathrm{SiO}_{2}$ ratio can be used to determine the depositional environment of a sedimentary rock due to its variability across different tectonic settings (Roser and Korsch, 1986). High values of both $\mathrm{K}_{2} \mathrm{O} / \mathrm{Na}_{2} \mathrm{O}$ and $\mathrm{SiO}_{2}$ suggest passive margin (PM) depositional environments, while low values of both $\mathrm{K}_{2} \mathrm{O} / \mathrm{Na}_{2} \mathrm{O}$ and $\mathrm{SiO}_{2}$ suggests an oceanic island arc (ARC) environment (Figure 3.3.3). Active continental margin (ACM) environments plot between PM and ARC environments. Measured ratios suggest a PM depositional environment for the majority of samples. Samples 11RAYJR070A and 01RAY258A plot in the fields of ACM and ARC.

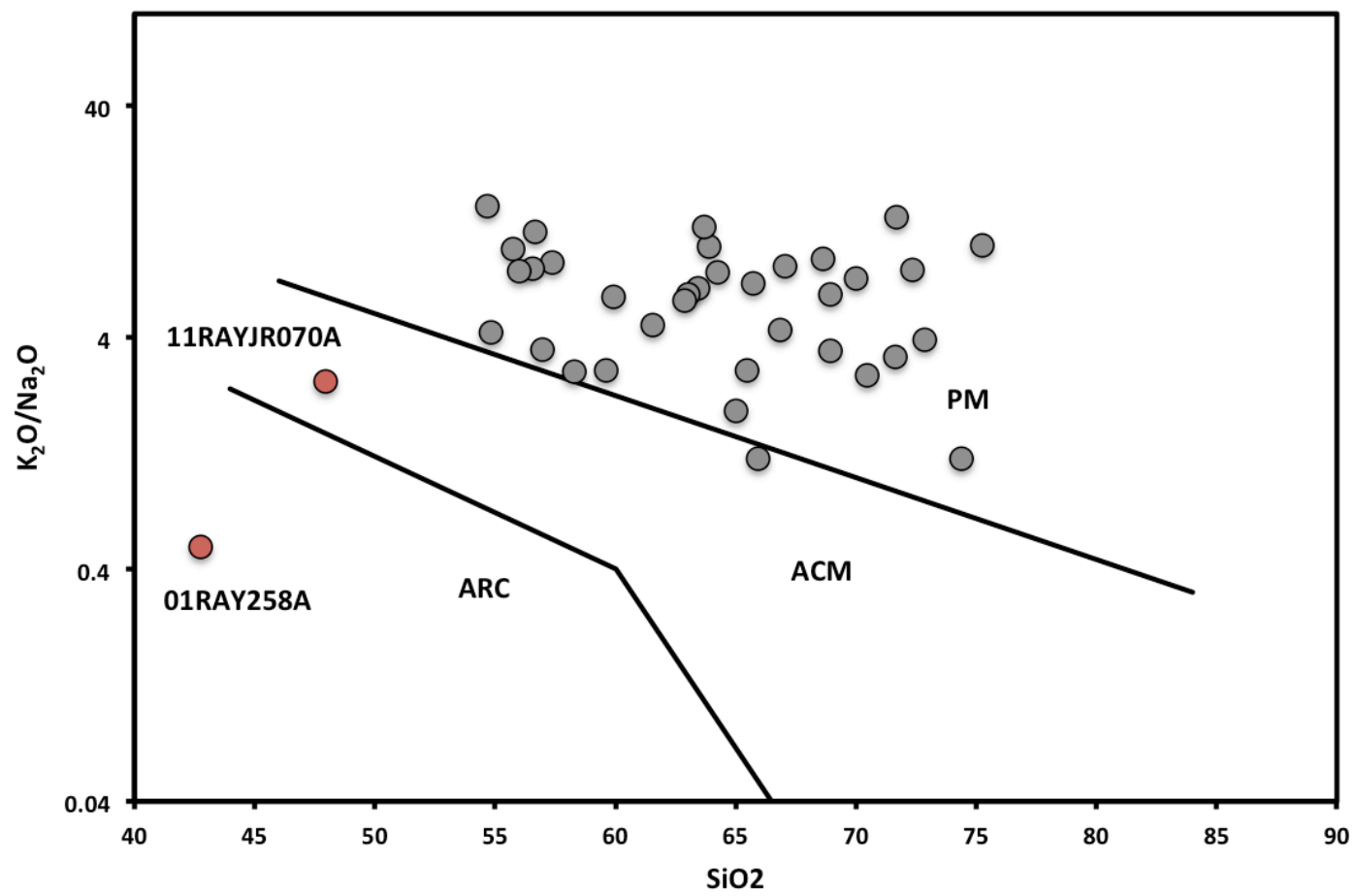

Figure 3.3.3 Depositional environment diagram for pelitic rocks (modified from Roser and Korsch, 1986). PM - Passive Margin; ACM - Active Continental Margin; ARC - Oceanic Island Arc. 


\subsection{XR- $\mu \mathrm{CT}$}

Garnet grains in samples 15RAYJR237B and 15RAYJR246A have a unimodal, normal size distribution (Figures 3.4.1a, b) while all other samples have a unimodal, positively skewed distribution (Figures 3.4.1c, d, e, f, g). Samples contain garnet counts ranging between $3.31 \mathrm{grt} / \mathrm{cm}^{3}$ and $306.9 \mathrm{grt} / \mathrm{cm}^{3}$ (Table 3.4.1) and crystals range widely in sizes.

In samples 15RAYJR237B, 15RAYJR246A, 00RAY231A, and 11RAYJR070A, the distribution of garnet crystal sizes appears uniform and evenly distributed across the samples (Figure 3.4.2). Sample 15RAYJR241A contains garnet crystals that are subhedral and not easily recognizable.

Garnet crystal sizes in sample 00RAY098A are not evenly distributed with the largest crystals on one side of the sample and smallest crystals on the other (Figure 3.4.2). This indicates the presence of different growth environments, either due to varying textural environment or due to varying chemistry. The largest garnet crystals from each side of the sample were identified for further analyses.

Sample 10RAYJR049A contains a garnet crystal that is significantly larger than all other crystals (Figure 3.4.1g and 3.4.2). This crystal, as well as a secondary large euhedral crystal, were both selected for further analyses. 


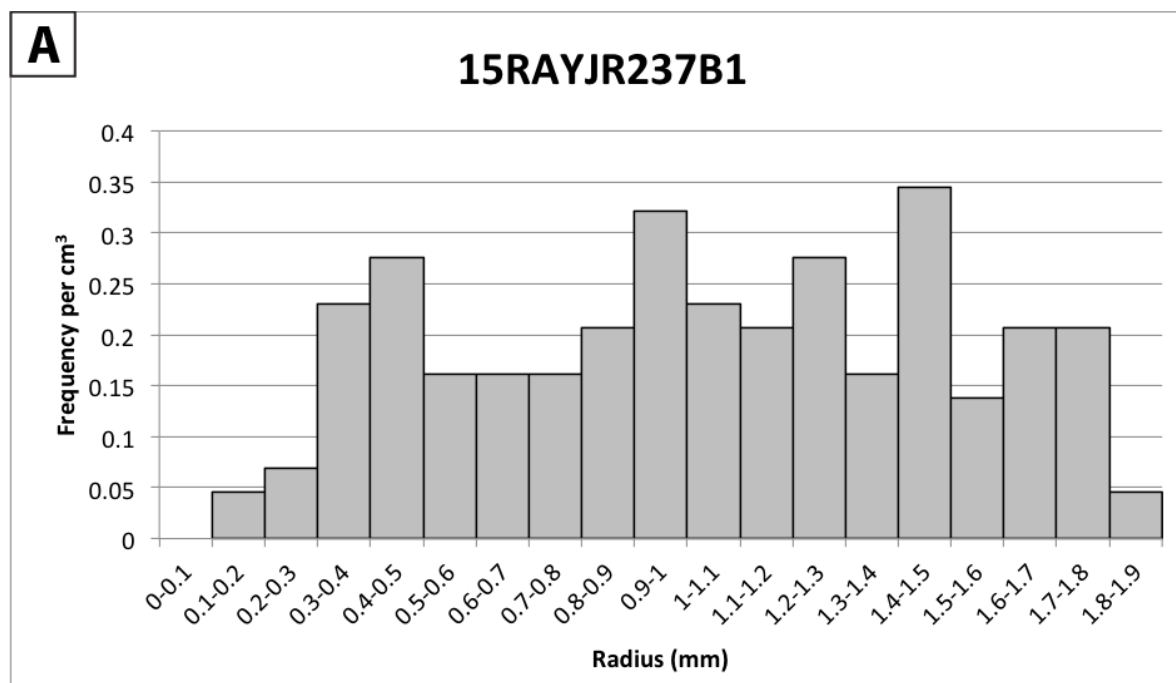

B

15RAYJR246A1

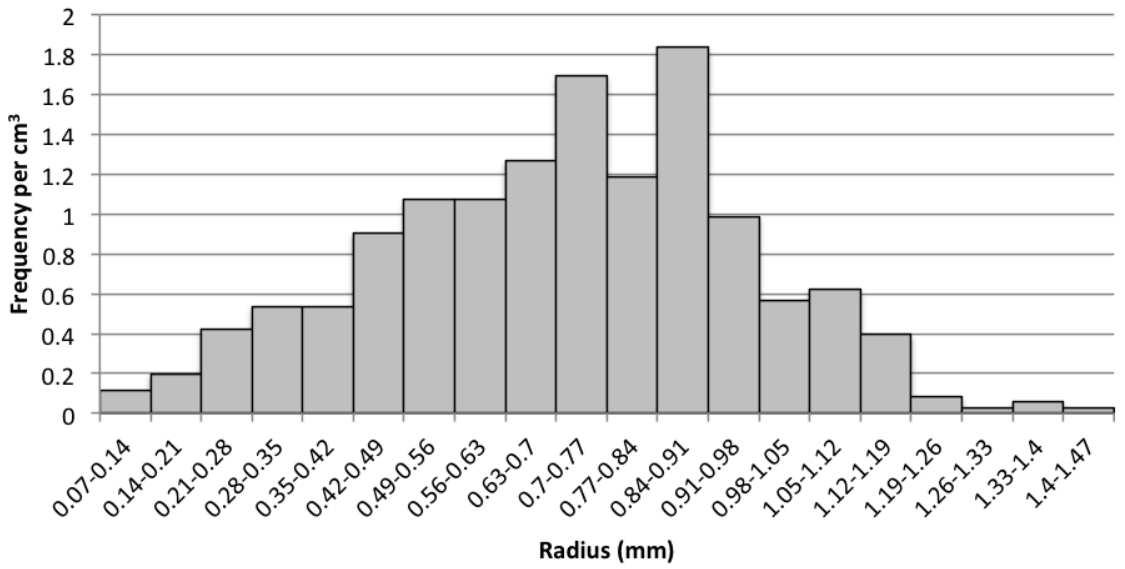

C

15RAYJR241A1

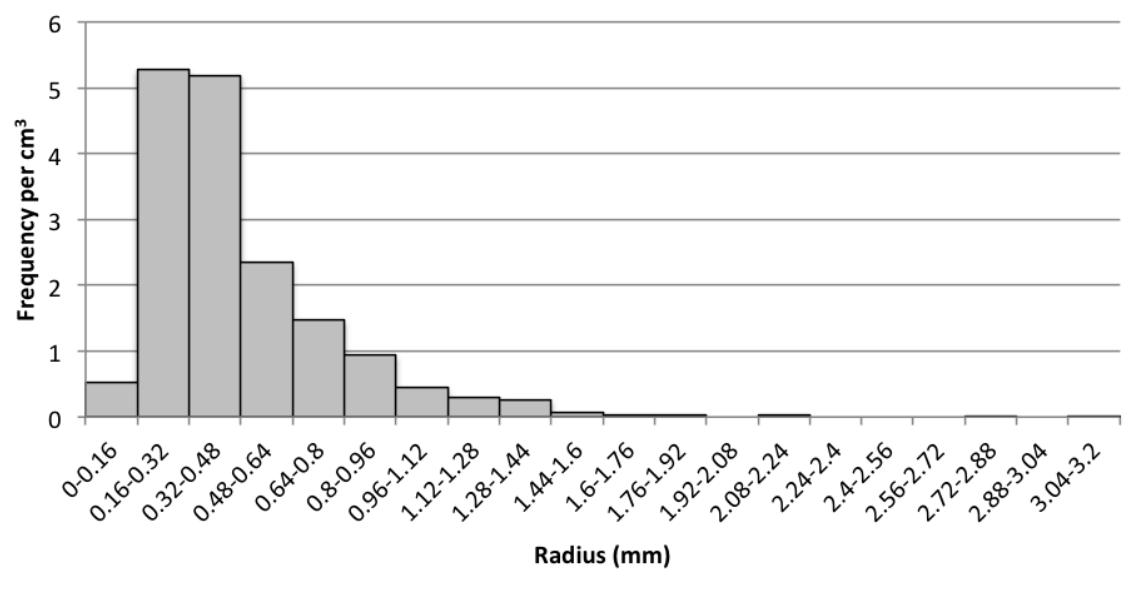




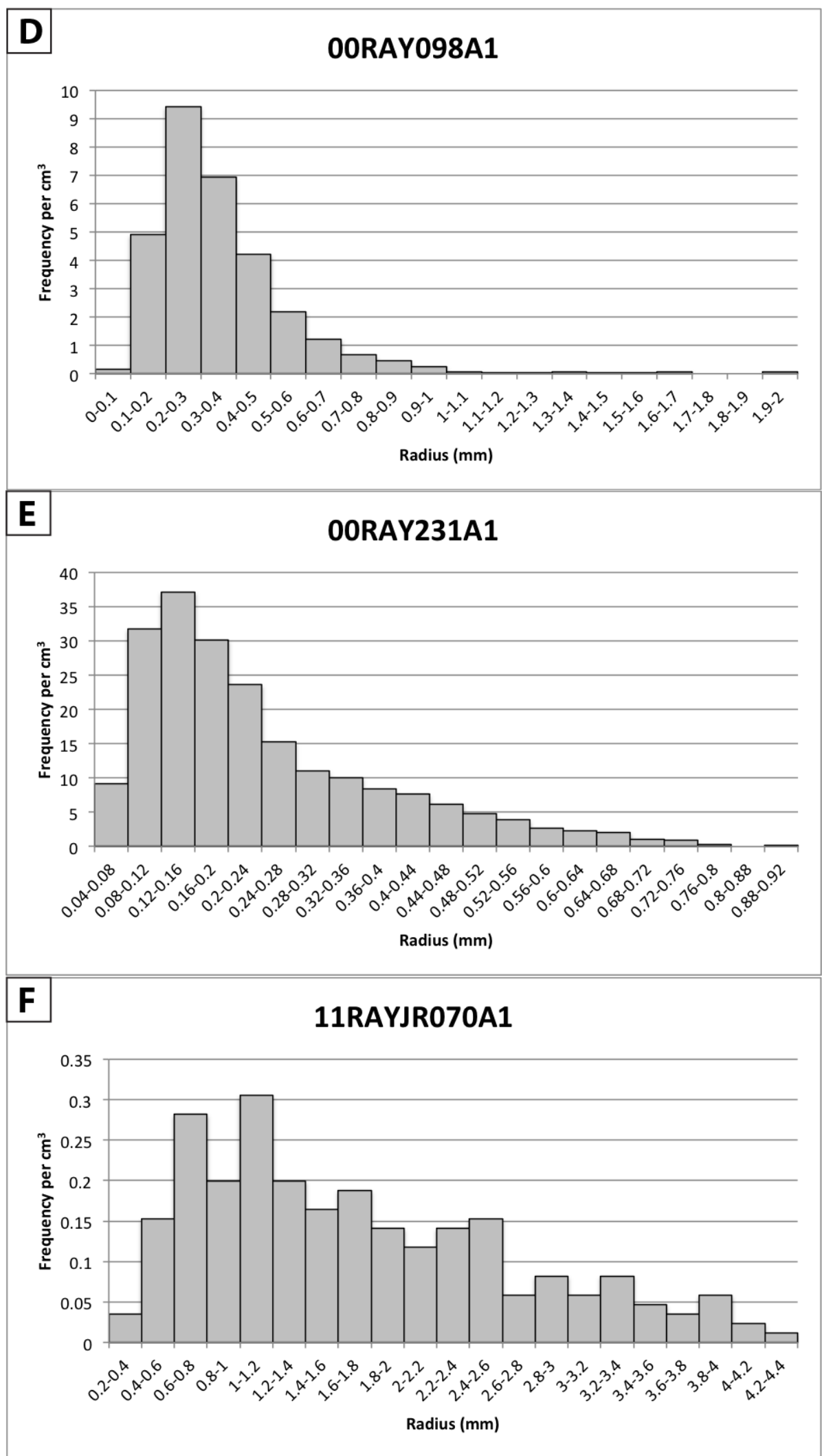




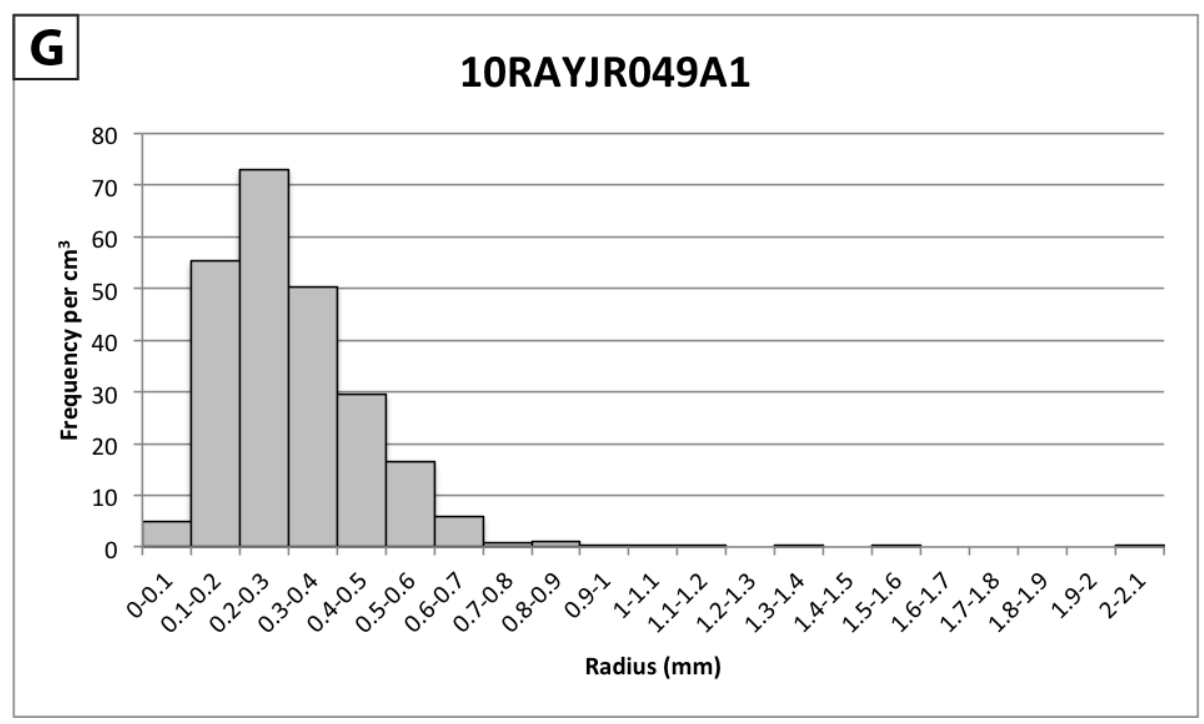

Figure 3.4.1 Crystal size distribution plots for representative samples scanned with XR- $\mu$ CT.

Table 3.4.1 Garnet crystal count and sizes.

\begin{tabular}{|l|c|c|c|}
\hline \multicolumn{1}{|c|}{ Sample \# } & $\begin{array}{c}\text { Garnet } \\
\text { count per } \\
\mathbf{c m}^{\mathbf{3}}\end{array}$ & $\begin{array}{c}\text { Smallest } \\
\text { Garnet } \\
\text { Radius } \mathbf{( m m})\end{array}$ & $\begin{array}{c}\text { Largest } \\
\text { Garnet } \\
\text { Radius } \mathbf{( m m})\end{array}$ \\
\hline 15RAYJR237B & 4.6 & 0.087 & 1.87 \\
\hline 15RAYJR246A & 18.7 & 0.086 & 1.43 \\
\hline 15RAYJR241A & 18.9 & 0.121 & 3.16 \\
\hline 00RAY098A & 39.4 & 0.075 & 1.98 \\
\hline 00RAY231A & 246.7 & 0.059 & 0.91 \\
\hline 11RAYJR070A & 3.3 & 0.418 & 4.16 \\
\hline 10RAYJR049A & 306.9 & 0.057 & 2.03 \\
\hline
\end{tabular}



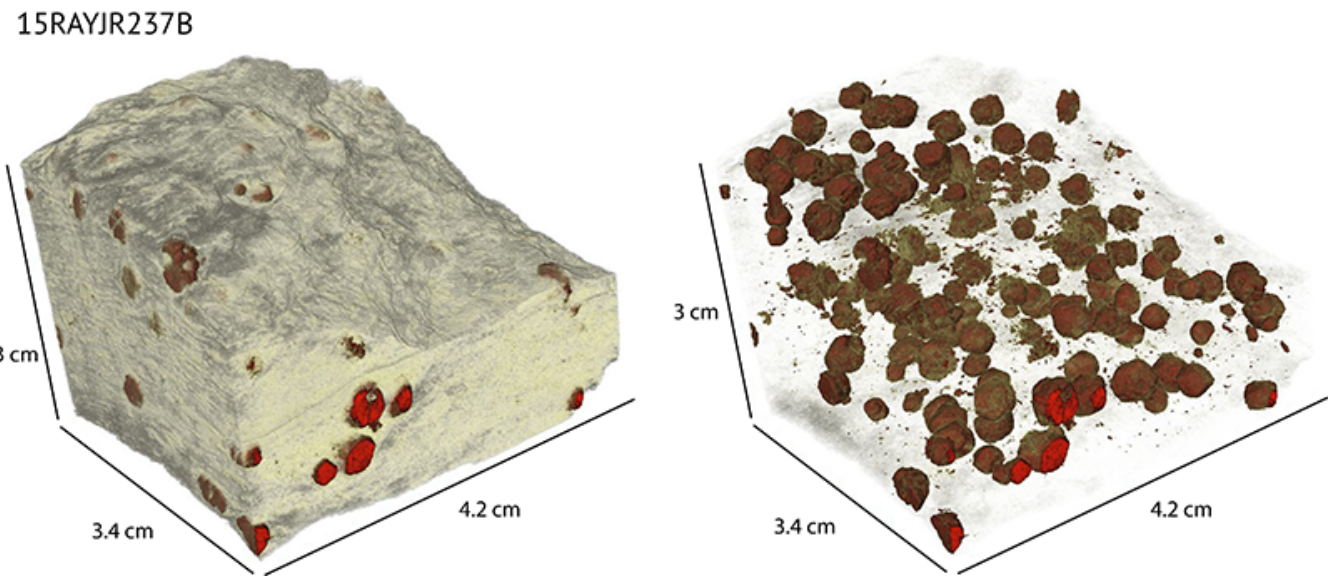

15RAYJR246A
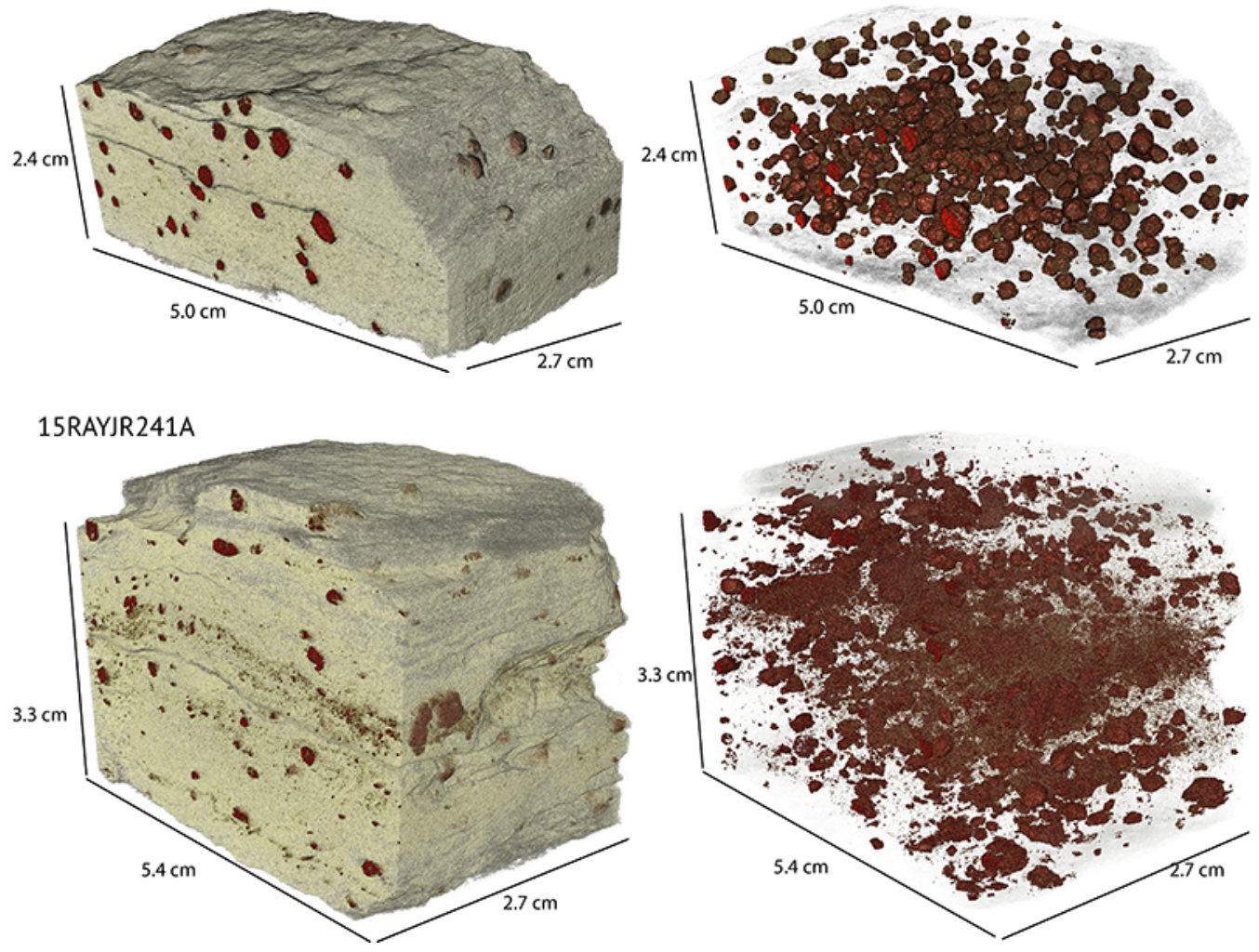

OORAY098A
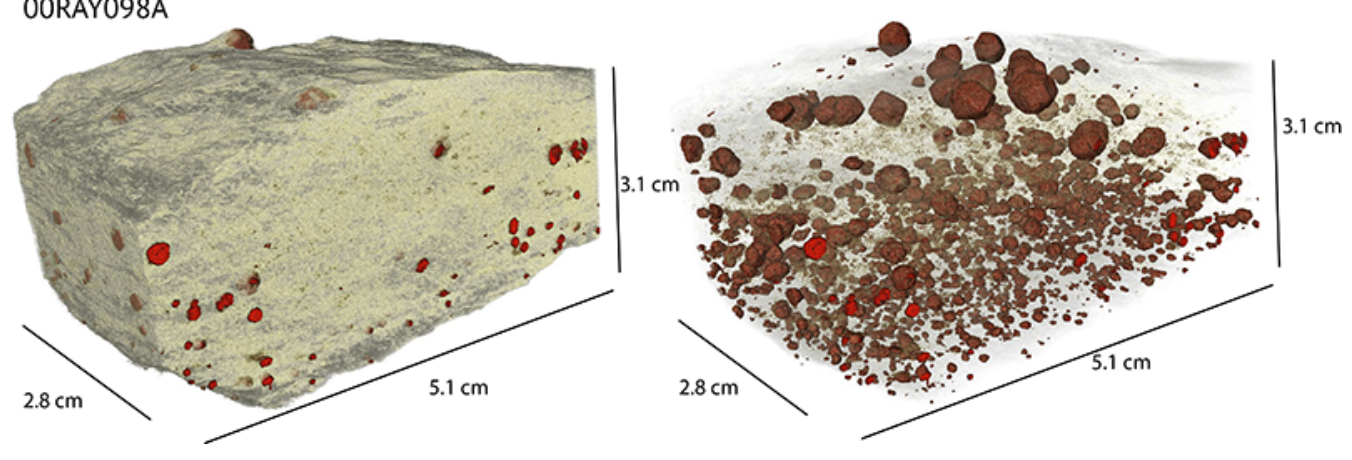

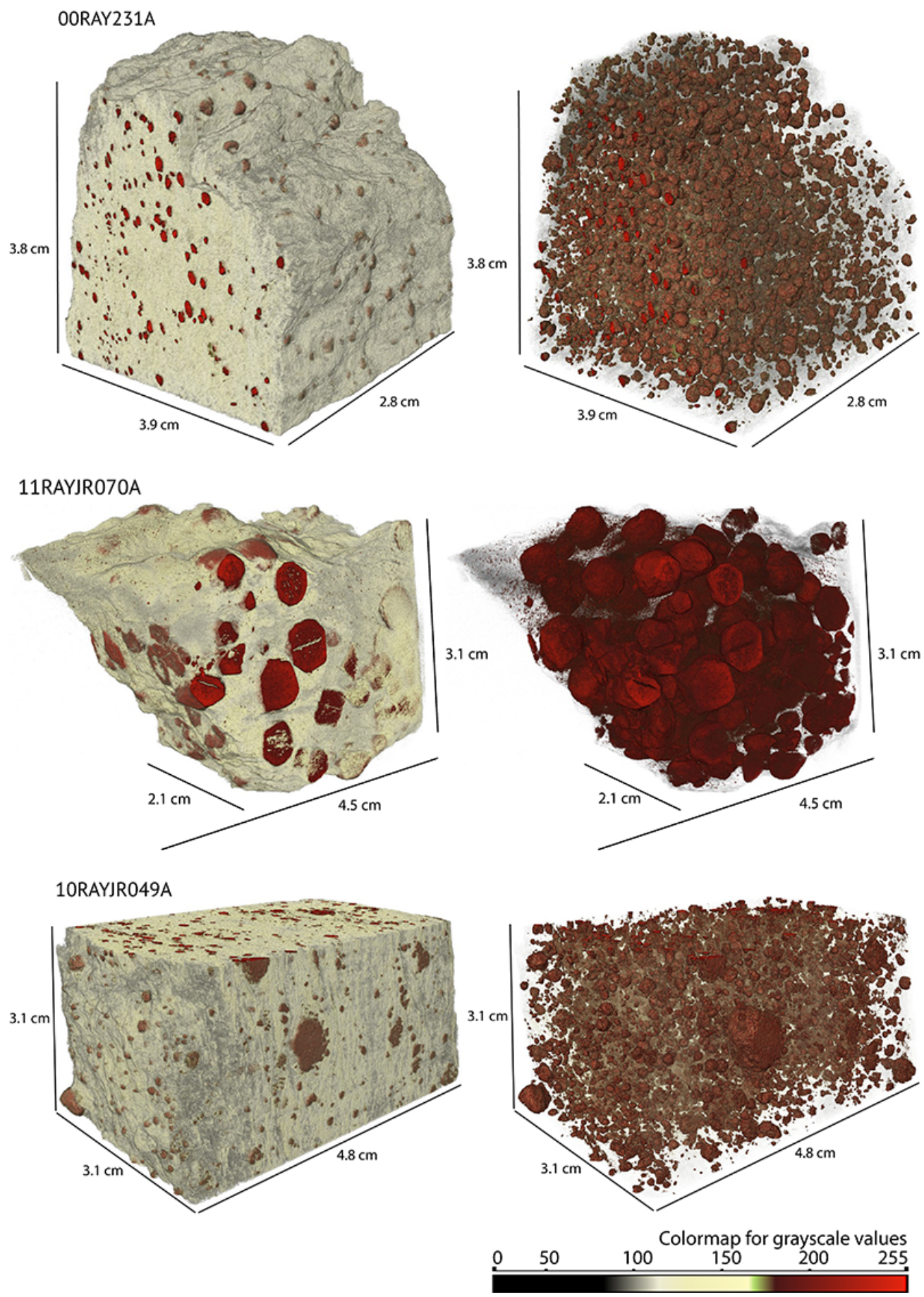

Figure 3.4.2 3D reconstruction images of representative samples. Colors were assigned to different grayscale values to best visualize different crystals. Red values best match garnet and higher density minerals, and pale yellow values best match the rock matrix. The image to the right for each sample uses the same colormap but with lower opacity values for grayscale values below 175. Small variations in the colormap were made for each sample to obtain the best visual results. 


\subsection{Garnet Compositional Zoning}

\section{RAYJR237B}

The garnet crystal analyzed in sample 15RAYJR237B is approximately $3.8 \mathrm{~mm}$ in diameter and is characterized by a symmetrical profile (Figure 3.5.1). Analyses for core compositions and values used for calculations of end-member values are in Appendix A. The almandine content increases from $0.68 \mathrm{xFe}$ at the core, to a peak of $0.75,1.5 \mathrm{~mm}$ away from the core, and decreases to 0.73 at the rim. The pyrope content increases from core to rim from 0.06 to $0.14 \mathrm{xMg}$. The spessartine content is $0.04 \mathrm{xMn}$ at the core, and depletes at the rim. Grossular $(\mathrm{xCa})$ decreases from 0.22 at the core to 0.13 at the rim. The profiles are smooth with no anomalies. $\mathrm{Y}_{2} \mathrm{O}_{3}$ peaks at $0.11 \mathrm{wt} . \%$ near the core and falls below detection limit of $0.02 \mathrm{wt} . \%$, approximately $0.3 \mathrm{~mm}$ away from the rim.

\section{RAYJR246A}

The largest garnet crystal analyzed in sample 15RAYJR246A has a diameter of approximately $3 \mathrm{~mm}$ and contains a symmetrical profile (Figure 3.5.1). xFe increases from core to rim from 0.59 to 0.71 xMg also increases from core to rim from 0.03 to 0.14. The $\mathrm{xMg}$ slope increases towards the rim. $\mathrm{xMn}$ decreases from 0.16 at the core to 0.01 at the rim. The xMn profile has a bell shape distribution. $\mathrm{xCa}$ content does not change significantly for the first $1.1 \mathrm{~mm}$ away from the core, and then decreases from 0.23 to 0.14 at the rim. $\mathrm{Y}_{2} \mathrm{O}_{3}$ is measured at $0.38 \mathrm{wt} . \%$ at the core, and falls below detection limit $0.7 \mathrm{~mm}$ away from the core. 

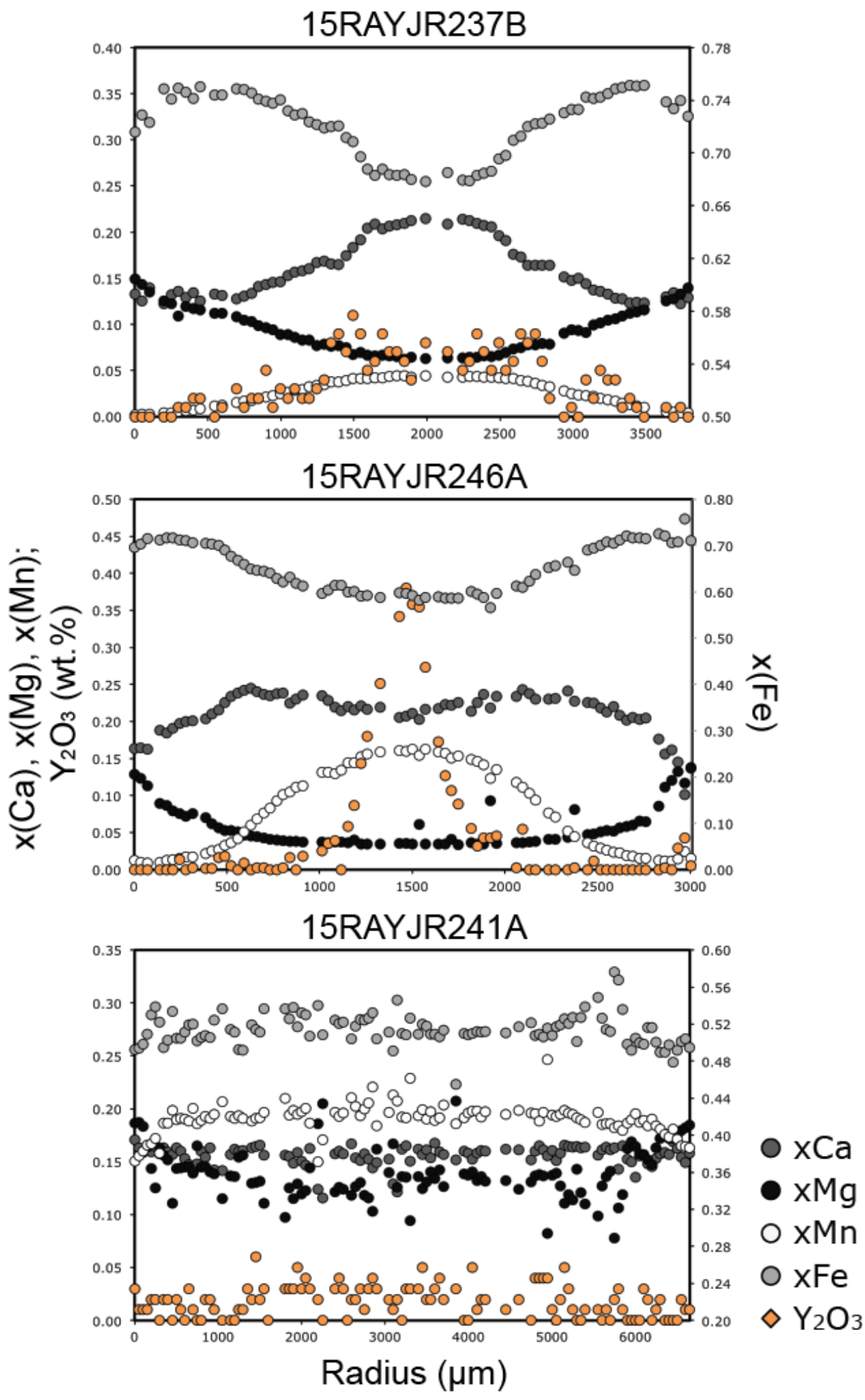

Figure 3.5.1 Garnet compositional profiles of the largest garnet crystals in samples 15RAYJR237B, 15RAYJR246A, and 15RAYJR241A. 


\section{RAYJR241A}

The garnet crystal analyzed in sample 15RAYJR241A contains a compositionally flat profile (Figure 3.5.1), typical of diffusive relaxation (Spear, 1993). The garnet has a diameter of $6.6 \mathrm{~mm}$. xFe ranges between 0.49 and 0.54 along a generally flat profile. $\mathrm{xMg}$ ranges between 0.11 and 0.18 , increasing slightly towards the rim. xMn ranges between 0.19 and 0.21 at the core, shallowly decreases to 0.18 towards the rim, and then steeply decreases to 0.16 near the rim. The $\mathrm{xCa}$ profile is flat, with values ranging between 0.13 and 0.16 .

A peak of $\mathrm{xFe}$ is observed on only one side of the profile, reaching an $\mathrm{xFe}$ content of 0.58. This peak matches a low peak for $\mathrm{xMg}$ of 0.078 , and is likely related to garnet being in contact with biotite during its growth. The peak is located $2.4 \mathrm{~mm}$ away from the core.

\section{O0RAY098A}

The biggest garnet analyzed in this sample has a radius of $4 \mathrm{~mm}$ (Figure 3.5.2). The composition is symmetrical about the core with a constant uniform composition across the core with no variation with respect to $\mathrm{xFe}, \mathrm{xMn}, \mathrm{xMg}$, and $\mathrm{xCa}$, which indicates diffusion-assisted re-equilibration of the garnet core with the bulk-rock composition (Spear, 1993), also referred to as relaxation of the compositional profile. A sharp change in $\mathrm{xFe}$ and $\mathrm{xCa}$ can be observed $1.8 \mathrm{~mm}$ from the core. $\mathrm{xFe}$ ranges from 0.77 to 0.79 in the core, and decreases to 0.74 before the sharp contact. After the contact, $\mathrm{xFe}$ is at 0.71 and increases to 0.74 at the outer rim. $\mathrm{xCa}$ varies between 0.1 and 0.14 in the core. At the 
contact, $\mathrm{xCa}$ sharply increases to 0.19 and decreases to 0.17 in the outer rim. $\mathrm{xMg}$ is measured at 0.07 in the core and increases to $0.1,1.4 \mathrm{~mm}$ from the core. $\mathrm{xMg}$ then decreases to $0.08,1.7 \mathrm{~mm}$ away from the core, and increases back to 0.1 at the rim. The $\mathrm{xMn}$ profile is generally flat with a core composition of 0.02 and a rim composition of 0.005. An increase of xMn can be observed between $1.3 \mathrm{~mm}$ and $1.8 \mathrm{~mm}$ away from the core, peaking at $0.055 \mathrm{xMn} . \mathrm{Y}_{2} \mathrm{O}_{3}$ peaks at $0.29 \mathrm{wt} . \%$ in the core and drops below detection limit at a distance of $1.3 \mathrm{~mm}$ from the core.

The second garnet analyzed in this sample has a compositionally relaxed profile with no sharp changes in composition. Its diameter is $2.5 \mathrm{~mm}$. $\mathrm{xFe}$ levels are at 0.78 for the majority of the crystal, and decrease for the outer $0.2 \mathrm{~mm}$ to $0.76 \mathrm{xMg}$ increases from core to rim, from 0.07 to 0.10 . $\mathrm{xCa}$ decreases from core to rim from 0.13 to 0.11 . $\mathrm{xMn}$ decreases from 0.02 at the core to 0 at the rim, with a small peak of $0.02,0.1 \mathrm{~mm}$ away from the rim. $\mathrm{Y}_{2} \mathrm{O}_{3}$ peaks at $0.37 \mathrm{wt} . \%$ and decreases below detection limit, $0.25 \mathrm{~mm}$ from the rim. 

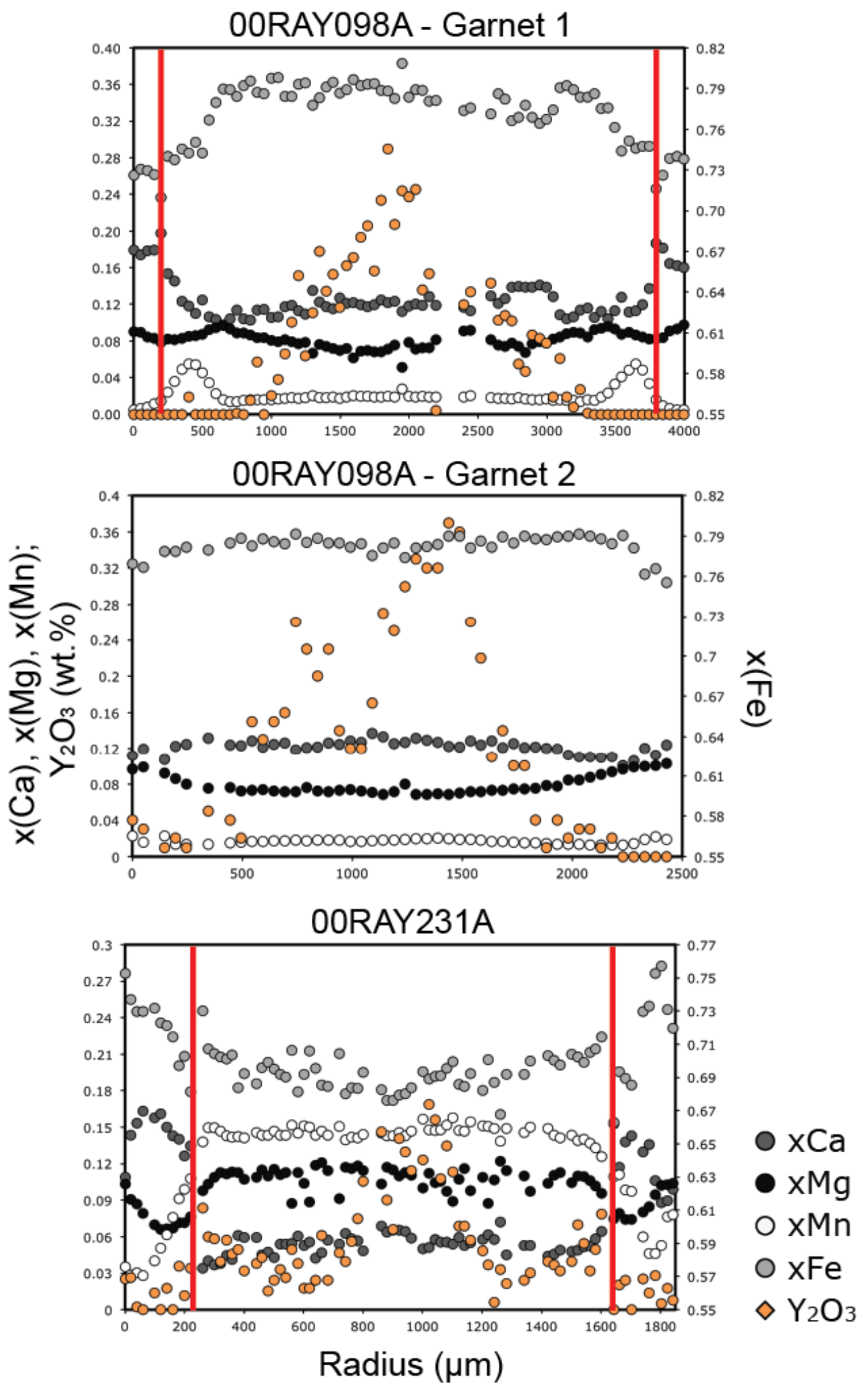

Figure 3.5.2 Garnet compositional profiles of the largest garnet crystals in samples 00RAY098A, and 00RAY231A. Red lines represent observed jumps in grossular contents. 


\section{O0RAY231A}

Similar to the first garnet in sample 00RAY098A, the garnet in sample 00RAY231A contains a core composition that is compositionally relaxed and that is followed by a sharp change in chemistry near the rim (Figure 3.5.2). The crystal analyzed has a radius of $1.85 \mathrm{~mm}$ and has a symmetrical profile. The sharp contact is observed approximately $0.7 \mathrm{~mm}$ away from the core, and corresponds to the textural boundary in the garnet crystal observed through petrography. The sharp contact is clearly observed in the grossular profile, with $\mathrm{xCa}$ values going from approximately 0.05 to 0.13 and is moderately observed in the pyrope and almandine profiles.

Overall, $\mathrm{xFe}$ ranges between 0.68 to 0.70 at the core, and narrows down to a range between 0.70 and 0.71 before the contact. Past the contact, $x F e$ drops to 0.68 and increases to 0.75 towards to rim. The $\mathrm{xMg}$ range is measured between 0.09 and 0.11 at the core, narrowing down to $0.11,0.5 \mathrm{~mm}$ from the core. $\mathrm{xMg}$ then decreases to 0.09 towards the contact. After the contact, $\mathrm{xMg}$ is measured at 0.075 and increases to 0.1 towards the rim. $\mathrm{xCa}$ is measured at 0.07 at the core, decreasing to 0.04 near the contact. After the contact, $\mathrm{xCa}$ is measured at 0.13 , increasing to 0.16 , and then decreasing to 0.09 at the rim. xMn values range between 0.14 and 0.15 for the majority of the core, decreasing slightly to 0.13 just before the contact. Past the contact, $\mathrm{xMn}$ decreases from 0.11 to 0.03 towards the rim. $\mathrm{Y}_{2} \mathrm{O}_{3}$ peaks at $0.17 \mathrm{wt} . \%$ at the core, and decreases to a low of $0.02,0.4 \mathrm{~mm}$ away from the core. A second peak of 0.08 can be observed $0.65 \mathrm{~mm}$ away from the core. Past the peak, $\mathrm{Y}_{2} \mathrm{O}_{3}$ decreases to below detection limit towards the rim. 


\section{RAYJR070A}

The garnet analyzed in sample 11RAYJR070A has a diameter of approximately $9.3 \mathrm{~mm}$ and its compositional profile is not symmetric (Figure 3.5.3). The compositional peaks for $\mathrm{xFe}, \mathrm{xMg}$, and $\mathrm{xCa}$ coincide, but do not match with the $\mathrm{xMn}$ peak. $\mathrm{xFe}$ has a low peak of 0.42 and increases to 0.84 towards the rim. $\mathrm{xMg}$ peaks at 0.29 and decreases to 0.10 towards the rim. $\mathrm{xCa}$ peaks at 0.20 and decreases to 0.07 towards the rim. $\mathrm{xMn}$ peaks at 0.1 and decreases to 0 towards the rim. $\mathrm{Y}_{2} \mathrm{O}_{3}$ is below detection limit throughout this garnet crystal.

\section{RAYJR049A}

Two garnet crystals from sample 10RAYJR049A were analyzed due to the irregular distribution of garnet in the sample. For both crystals, the compositional profiles are not symmetrical and did not show any clear trends (Figure 3.5.3). The profile likely results from a cluster of individual garnet crystals that came into contact during their growth. 


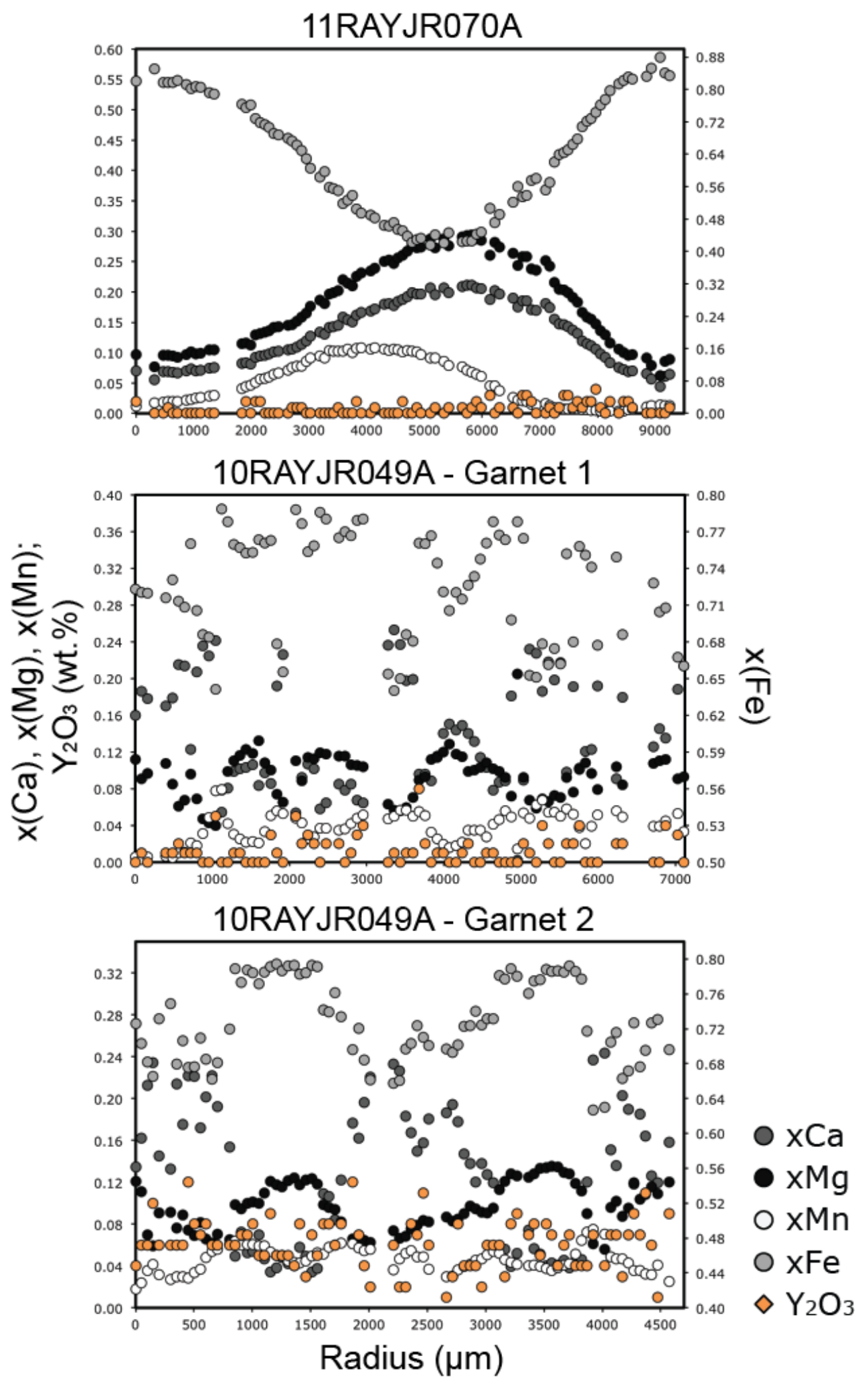

Figure 3.5.3 Garnet compositional profiles of the largest garnet crystals in samples 11RAYJR070A and 10RAYJR049A. 


\subsection{Mineral Inclusions in Garnet}

Sample 15RAYJR237B contains abundant zircon and a few monazite crystals (Table 3.6.1). Inclusions of quartz, ilmenite, rutile and allanite are also observed. Monazite occurs exclusively in the matrix as anhedral and altered crystals (Figure 3.6.1a). Zircon occurs in garnet as stubby anhedral crystals that are $\leq 60 \mu \mathrm{m}$. These zircon crystals either contain resorbed, inclusion rich, irregular convolute zoning (Figure 3.6.1c; Corfu et al., 2003; Gagnevin et al., 2010) or contain sector-zoned cores separated from a thin rim by a ragged boundary (Figure 3.6.1e). The size and internal complexity of these zircon grains makes them unsuitable for conventional age dating. Rutile crystals are $\leq 200 \mu \mathrm{m}$ and contain abundant inclusions (Figure 3.6.1h).

Table 3.6.1 Summary of inclusions observed in garnet for representative samples. Mineral abbreviations from Siivola and Schmid (2007).

\begin{tabular}{|c|c|c|}
\hline Sample \# & $\begin{array}{l}\text { Inclusions identified } \\
\text { through EMPA and SEM } \\
\text { Mapping }\end{array}$ & Notes \\
\hline 15RAYJR237 & Qtz, Ilm, Rt, Zrc, Aln & $\begin{array}{l}\text { - Aln is scarce and crystals are less than } 5 \mu \mathrm{m} \\
\text { in size. } \\
\text { - Anhedral Mnz crystals are observed in the } \\
\text { matrix. }\end{array}$ \\
\hline 15RAYJR246 & Qtz, Ilm, Rt, Ap, Zrc, Aln & - Ilm forms rims around Rt (figure 3.6.2). \\
\hline 15RAYJR241 & Qtz, Bt, Ilm, Rt, Ap, Zrc & - Ilm forms rims around Rt. \\
\hline 00RAY098 & $\begin{array}{l}\text { Qtz, Bt, Ilm, Rt, Ap, Zrc, } \\
\text { Xtm, Aln }\end{array}$ & $\begin{array}{l}\text { - Only Rt and Zrc are present near the rim. } \\
\text { - A single crystal of Xtm was observed in the } \\
\text { core of garnet. }\end{array}$ \\
\hline 00RAY231 & Qtz, Bt, Ilm, Zrc, Rt, Mnz & $\begin{array}{l}\text { - Ilm and Zrc are only observed in the rim. } \\
\text { - Bt is only observed in the core. }\end{array}$ \\
\hline 11RAYJR070 & Qtz, Plg, Ilm, Rt, Ap, Mnz & \\
\hline 10RAYJR049 & $\begin{array}{l}\text { Qtz, Ilm, Rt, Zr, Aln, Fe } \\
\text { Oxide, Py }\end{array}$ & - Aln appears highly altered. \\
\hline
\end{tabular}




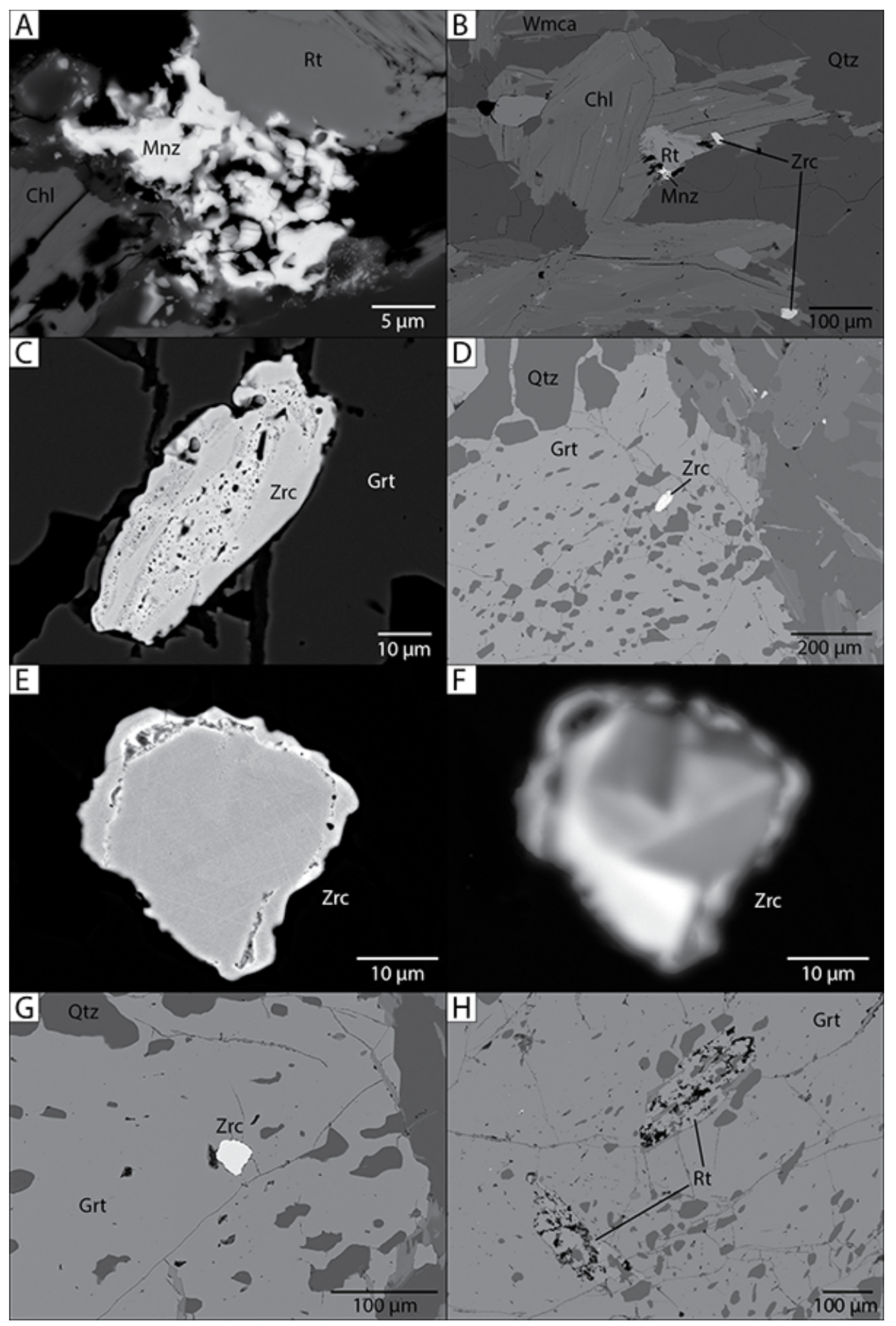

Figure 3.6.1 SEM images of inclusions in garnet in sample 15RAYJR237B. A, B) BSE images of monazite grain in the matrix. C, D) BSE images of largest zircon grain in garnet. E, F, G) BSE and cathodoluminescent images of a second zircon grain in garnet with metamorphic overgrowth. H) BSE image of rutile in garnet. 
Sample 15RAYJR246A contains quartz, ilmenite, apatite, zircon, allanite and rutile inclusions (Table 3.6.1). The largest zircon crystals contain sector-zoned cores and rims separated by a rough boundary (Figure 3.6.2a, b, c, d, e). The largest crystal in garnet is $\leq$ $100 \mu \mathrm{m}$ in length. The rim is up to $20 \mu \mathrm{m}$ in thickness, but is fractured where it is thicker. Resorbed, inclusion-rich textures are common in zircons of this sample and are irregularly zoned. Allanite forms anhedral, altered crystals (Figure 3.6.2f). Rutile in garnet is only observed as an inclusion $(10 \mu \mathrm{m})$ within an ilmenite inclusion in garnet (Figure 3.6.2g). Ilmenite in the matrix commonly forms rims around rutile (Figure 3.6.2h).

Sample 00RAY098A contains several zircon inclusions of varying sizes, as well as quartz, biotite, ilmenite, rutile, apatite, xenotime and allanite inclusions (Table 3.6.1). The largest crystal in garnet is $40 \mu \mathrm{m}$ in length, is inclusion-rich, and contains sectorzoned textures (Figure 3.6.3a, b, c, d, e). Zircon crystals in the matrix are either inclusionpoor or inclusion-rich (Figure 3.6.3f, g, h).

Sample 00RAY231A contains quartz, ilmenite, biotite, rutile, monazite and zircon inclusions (Table 3.6.1). Monazite crystals are $\leq 8 \mu \mathrm{m}$ in length. Observed crystals larger than $5 \mu \mathrm{m}$ either contains fractures or formed along cracks in garnet (Figure 3.6.4a, b, c, d). The largest zircon crystal in garnet is $20 \mu \mathrm{m}$ in length and contains a core and rim separated by a rough boundary (Figure 3.6.4e, f, g). Rutile is observed as small garnet inclusions that are $\leq 4 \mu \mathrm{m}$ in length (Figure 3.6.4h). 


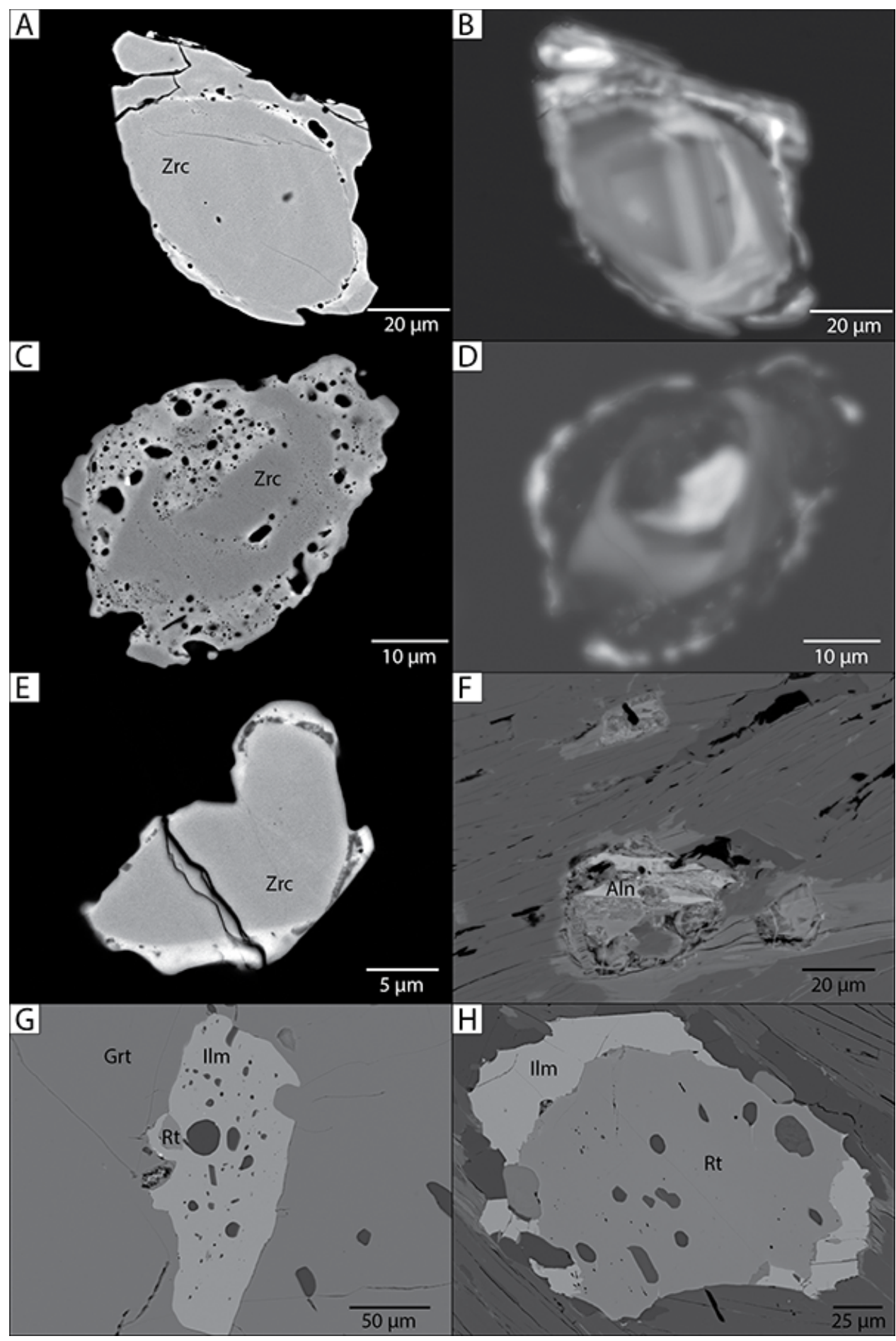

Figure 3.6.2 SEM images of inclusions in garnet in sample 15RAYJR246B. A, B, C, D, E) BSE and cathodoluminescent images of largest zircon grains in garnet. F) BSE image of allanite in matrix. G) BSE image of rutile in ilmenite in garnet. H) BSE image of ilmenite rim around rutile in matrix. 


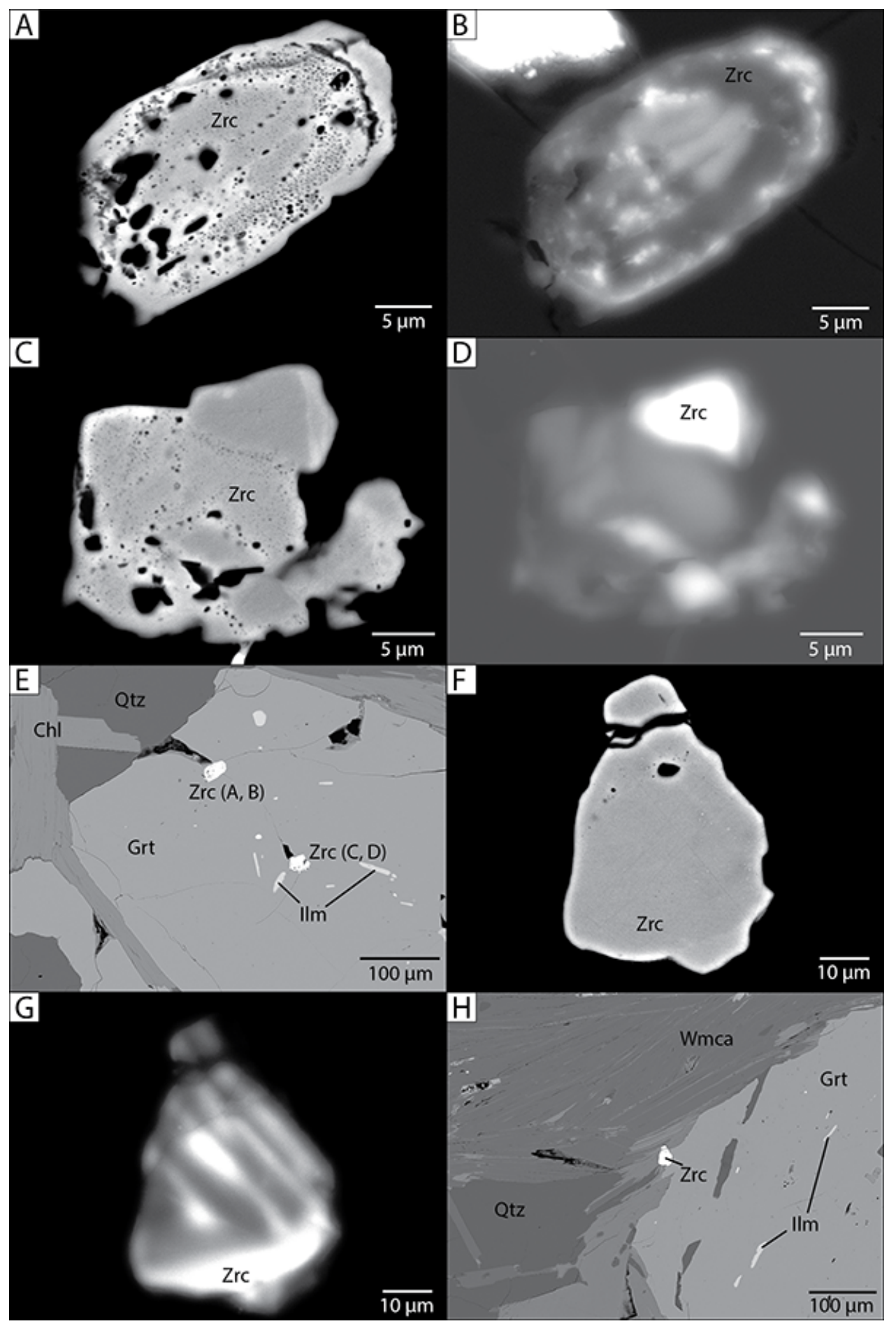

Figure 3.6.3 SEM images of inclusions in garnet in sample 00RAY098A. A, B, C, D, E) BSE and cathodoluminescent images of largest zircon grains in garnet. F, G, H) BSE and cathodoluminescent images of zircon grain in contact with garnet and the matrix. 


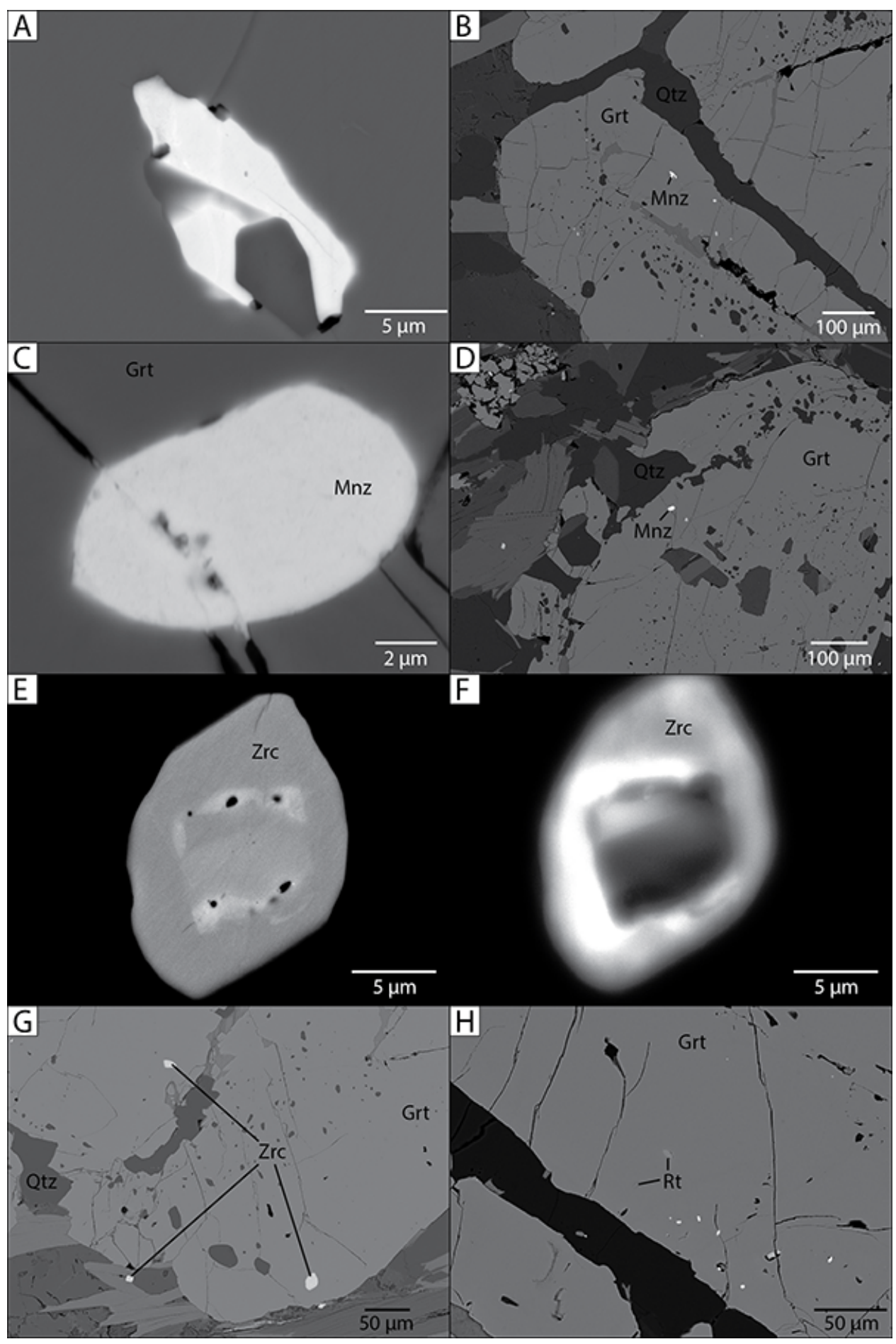

Figure 3.6.4 SEM images of inclusions in garnet in sample 00RAY231A. A, B, C, D) BSE images of largest monazite grains in garnet. The second crystal is located along a crack. E, F, G) BSE and cathodoluminescent images of largest zircon grain in garnet. H) BSE image of rutile in garnet. 


\subsection{Thermodynamic Phase Equilibrium Modeling}

For the representative samples, peak assemblage fields range between 525 and $700{ }^{\circ} \mathrm{C}$ and 5 to $10 \mathrm{kbar}$. Garnet is predicted to be part of the stable assemblage within this P-T range for all samples, but the P-T position of the garnet-in reaction is highly variable, likely reflecting the different Mn contents of the rocks.

The peak equilibrium assemblage diagram for sample 15RAYJR237B is predicted to form between 565 and $630^{\circ} \mathrm{C}$, and above $7 \mathrm{kbar}$ (Figure 3.7.1). The upper $\mathrm{T}$ boundary is defined by the absence of kyanite and/or staurolite in the sample. The lower T boundary is defined by the absence of rutile. Isopleths matching the core composition of the largest garnet crystal intersect at approximately $540{ }^{\circ} \mathrm{C}$ and $5.5 \mathrm{kbar}$ (Figure 3.7.2). 


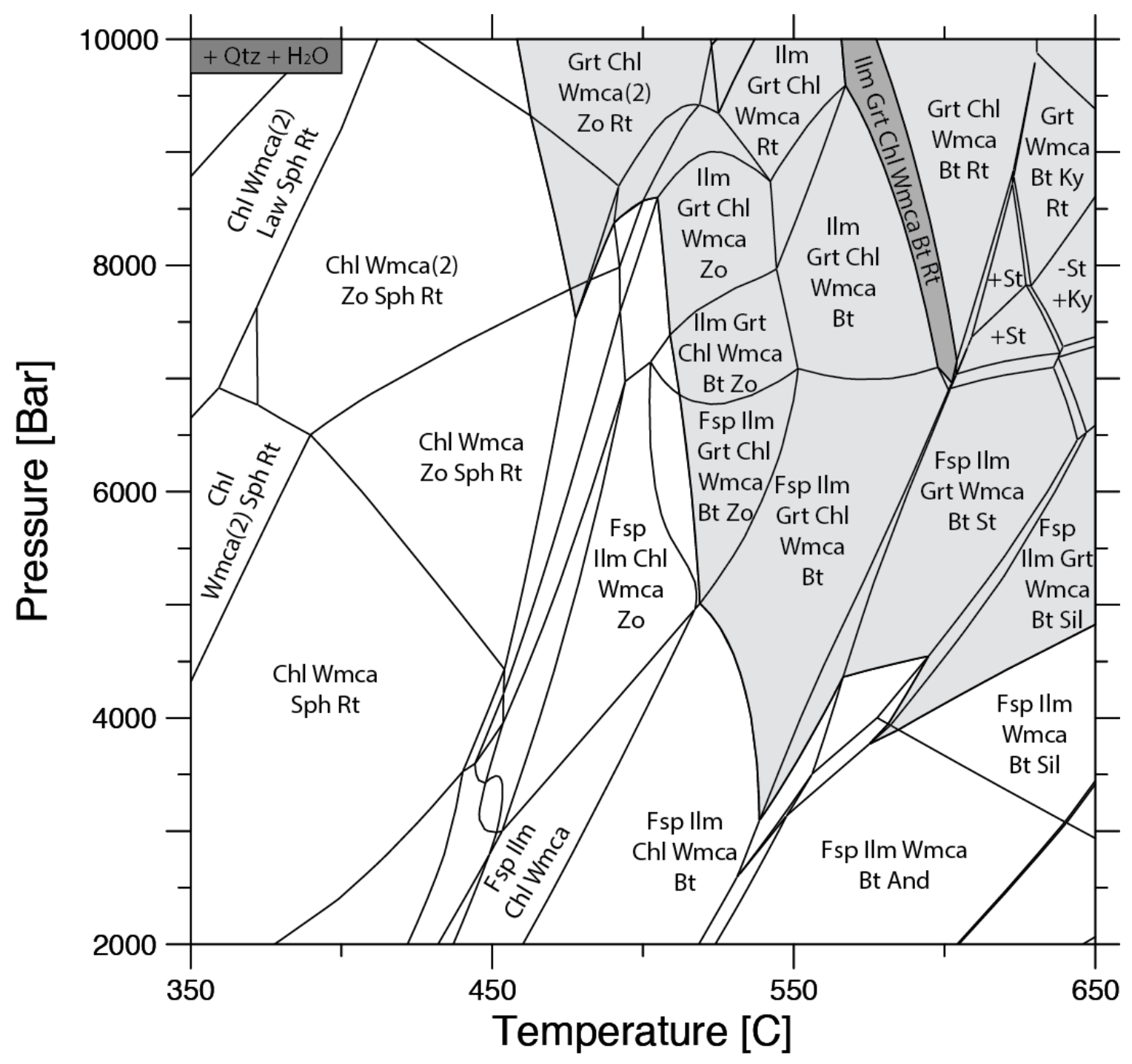

Figure 3.7.1 Phase equilibrium diagram for sample 15RAYJR237B. The light grey field represents the garnet bearing assemblages, and the dark grey field matches the observed mineralogy of the sample. 


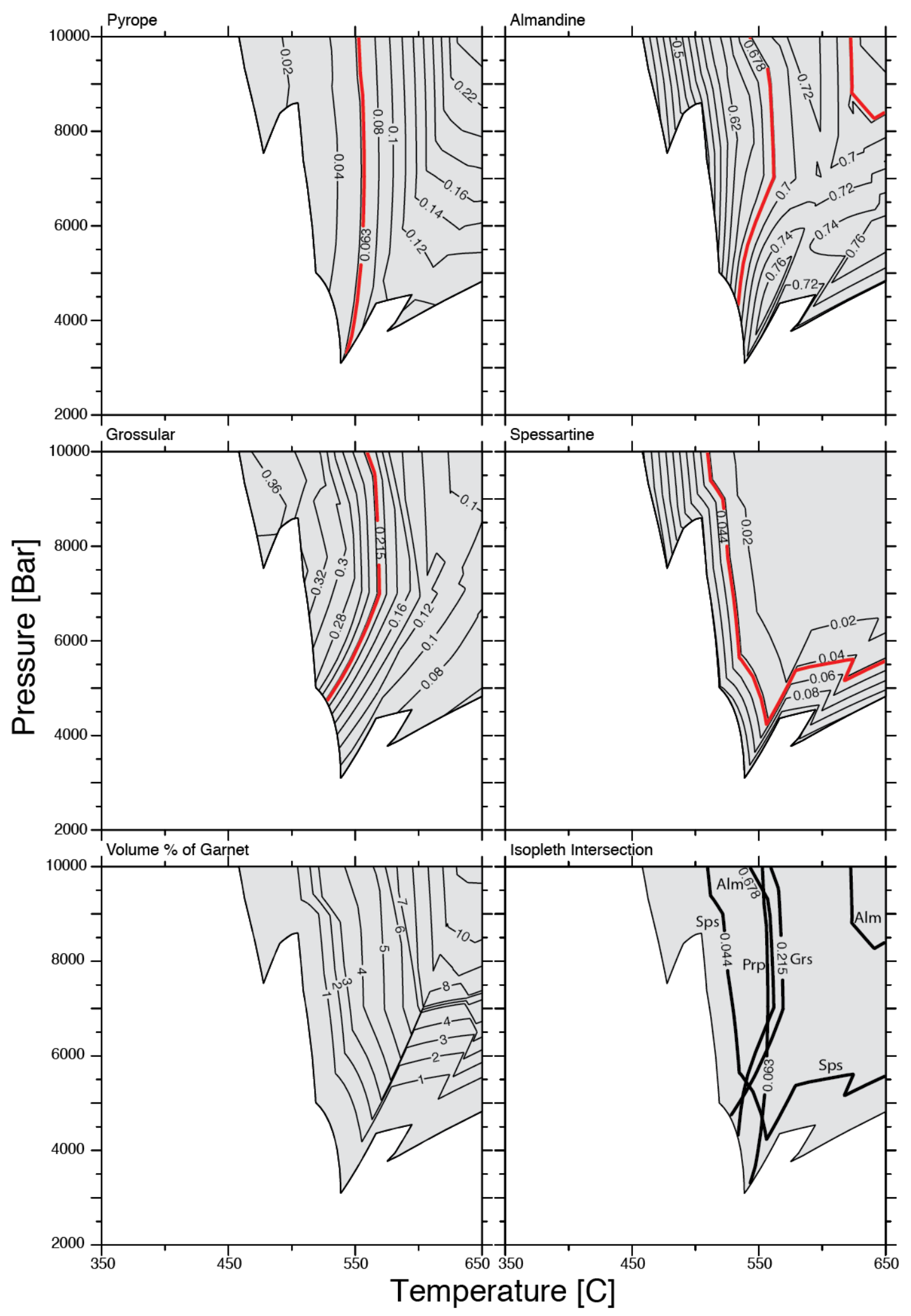

Figure 3.7.2 Garnet end-member isopleths of sample 15RAYJR237B. 
For sample 15RAYJR246A, the peak assemblage field ranges between 550 and $700{ }^{\circ} \mathrm{C}$, and 4.6 and 9.5 kbar (Figure 3.7.3). Garnet core isopleths intersect at approximately 515 ${ }^{\circ} \mathrm{C}$ and 4 kbar (Figure 3.7.4).

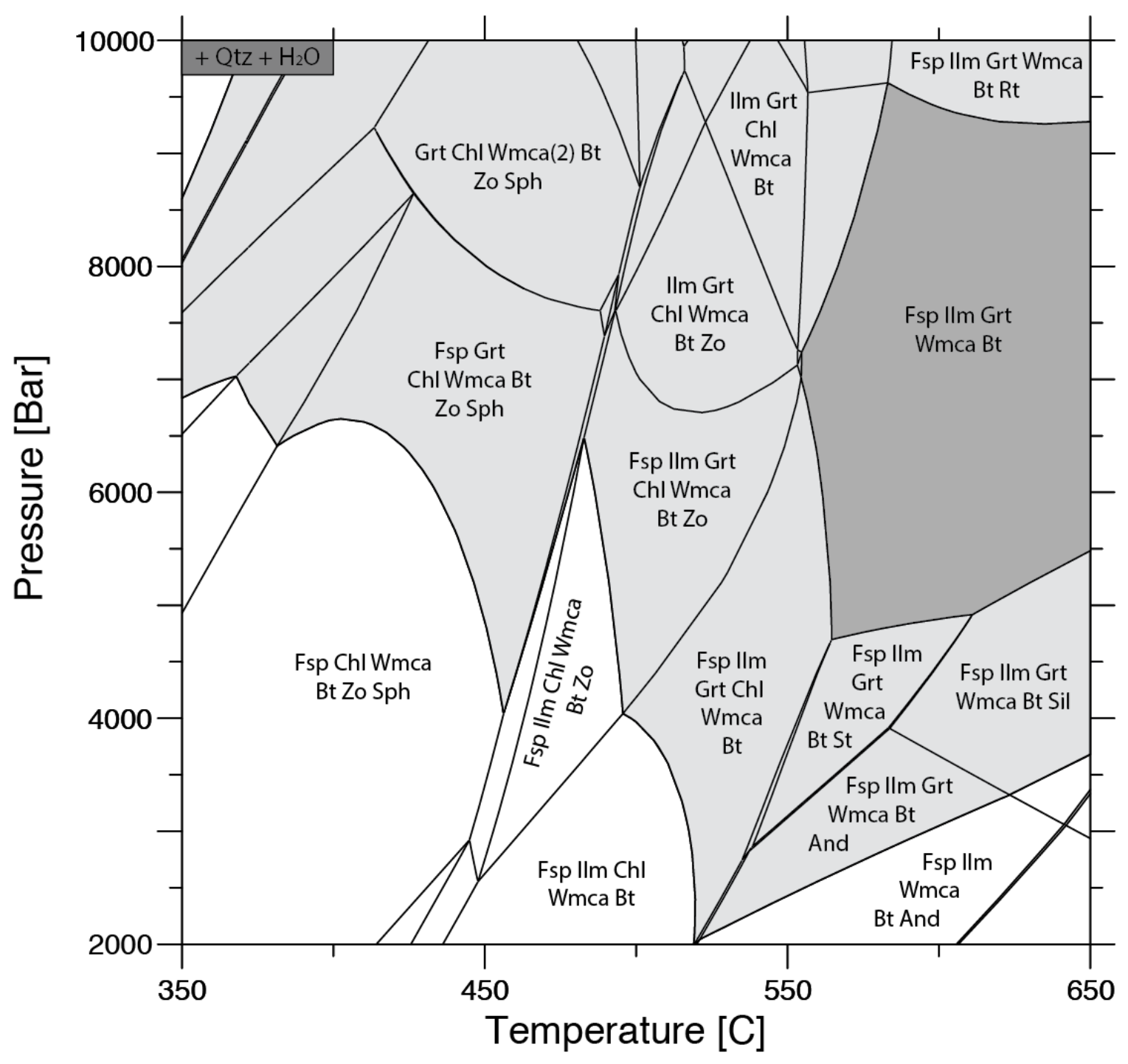

Figure 3.7.3 Phase equilibrium diagram for sample 15RAYJR246A. 


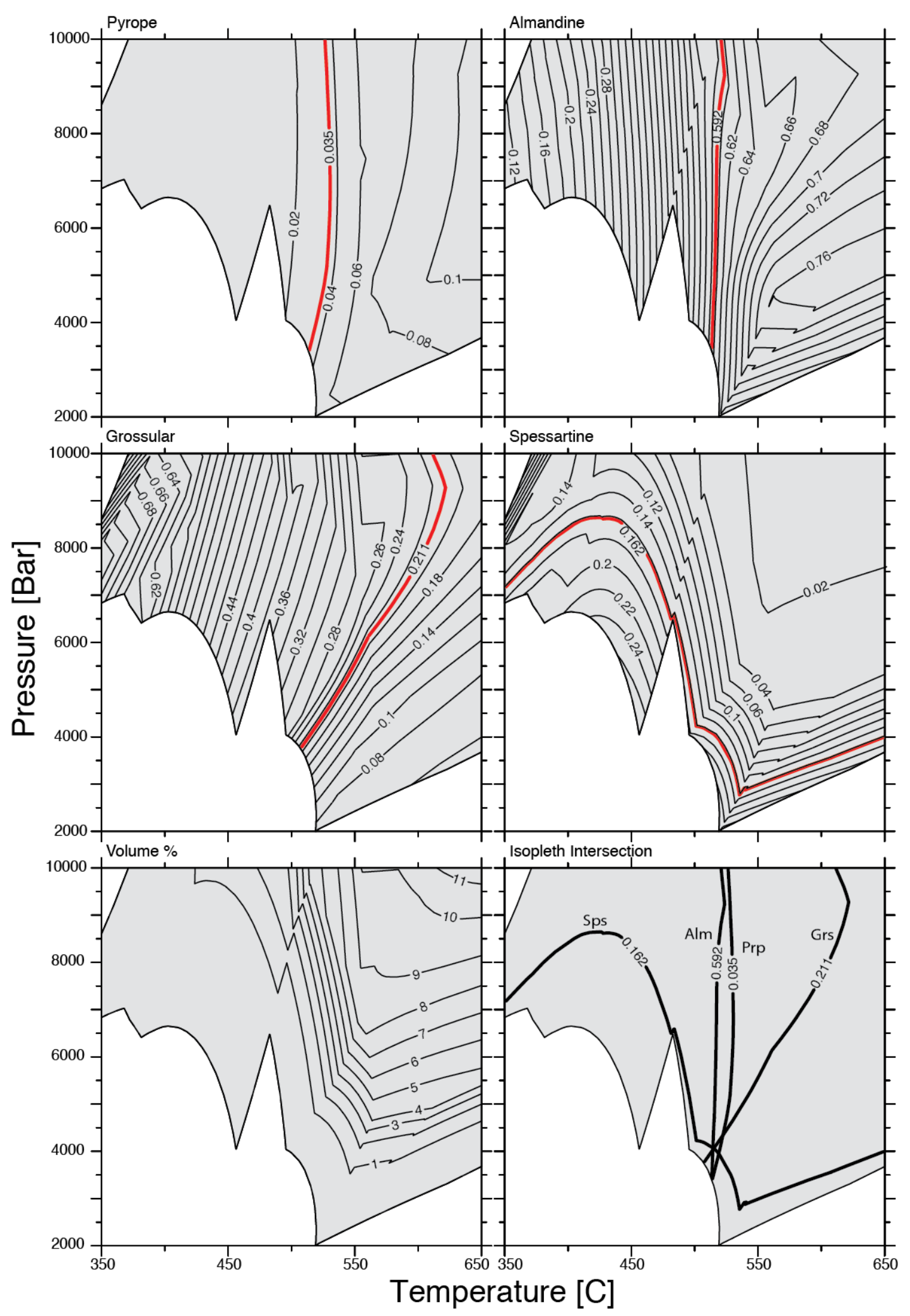

Figure 3.7.4 Garnet end-member isopleths for sample 15RAYJR246A. 
Sample 15RAYJR241A has a peak assemblage field ranging between 525 and $700{ }^{\circ} \mathrm{C}$, and 8.2 and $10 \mathrm{kbar}$ (Figure 3.7.5). Garnet-bearing assemblages are stable across the majority of this diagram likely due to high whole-rock $\mathrm{MnO}$ in this sample. Garnet core isopleths intersect at approximately $520^{\circ} \mathrm{C}$ and $5 \mathrm{kbar}$ (Figure 3.7.6).

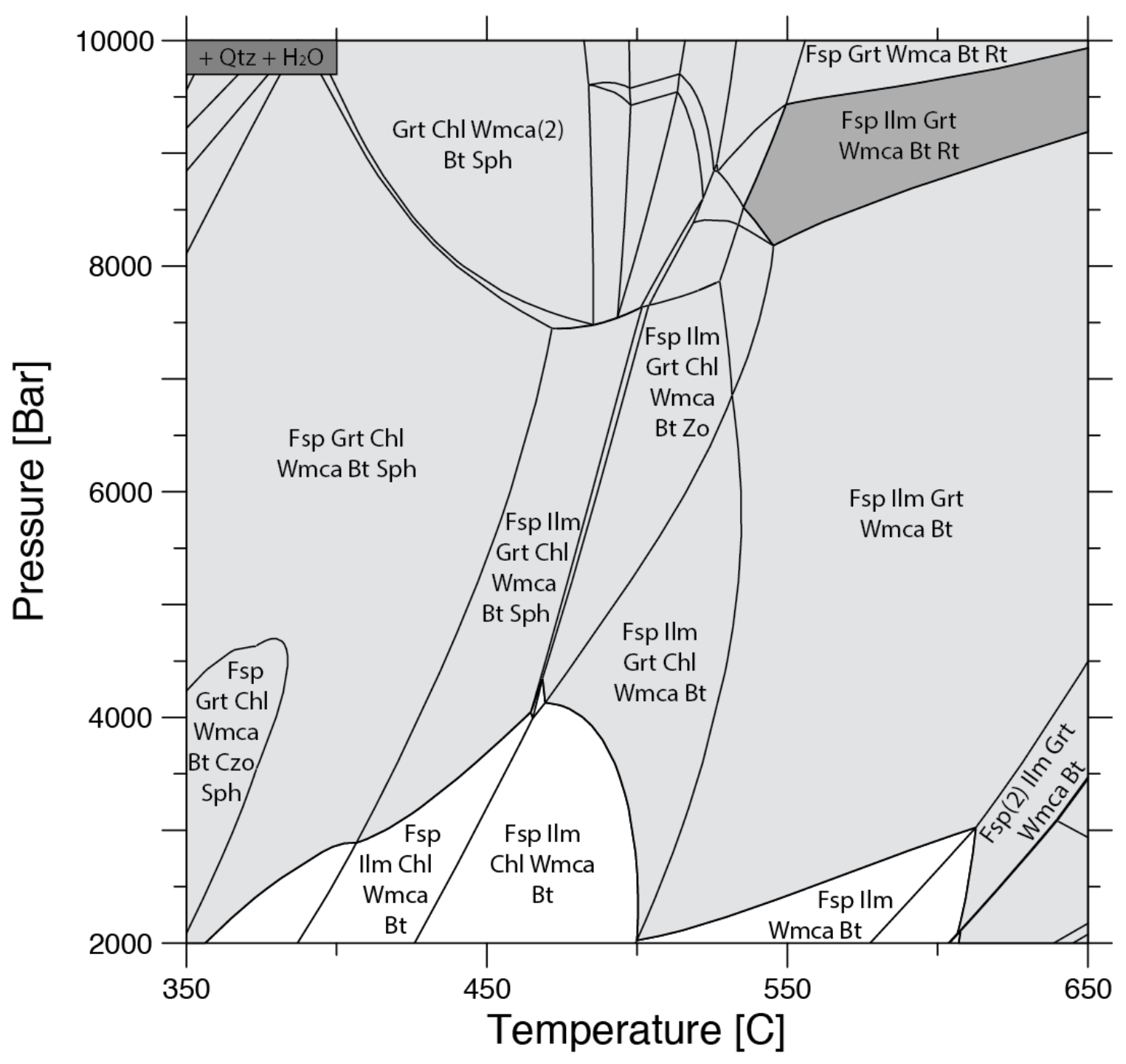

Figure 3.7.5 Phase equilibrium diagram for sample 15RAYJR241A. 


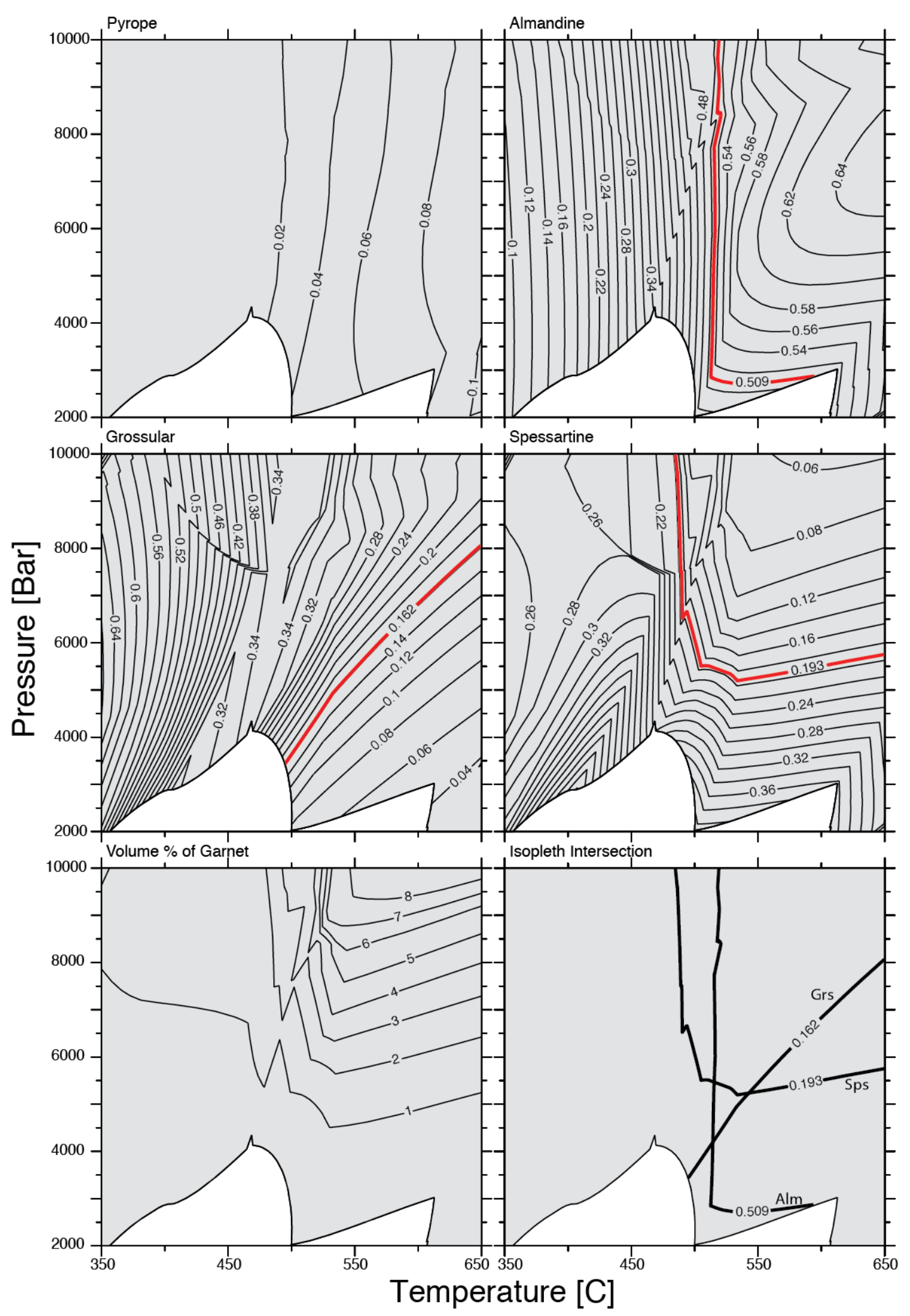

Figure 3.7.6 Garnet end-member isopleths for sample 15RAYJR241A. 
Sample 00RAY098A contains a peak assemblage field between 575 and $700{ }^{\circ} \mathrm{C}$, and above 7.4 kbar (Figure 3.7.7). Garnet core isopleths do not intersect, and the observed core almandine content is higher than all isopleths defined by the P-T range as a result of this modeling method not considering diffusion (Figure 3.7.8).

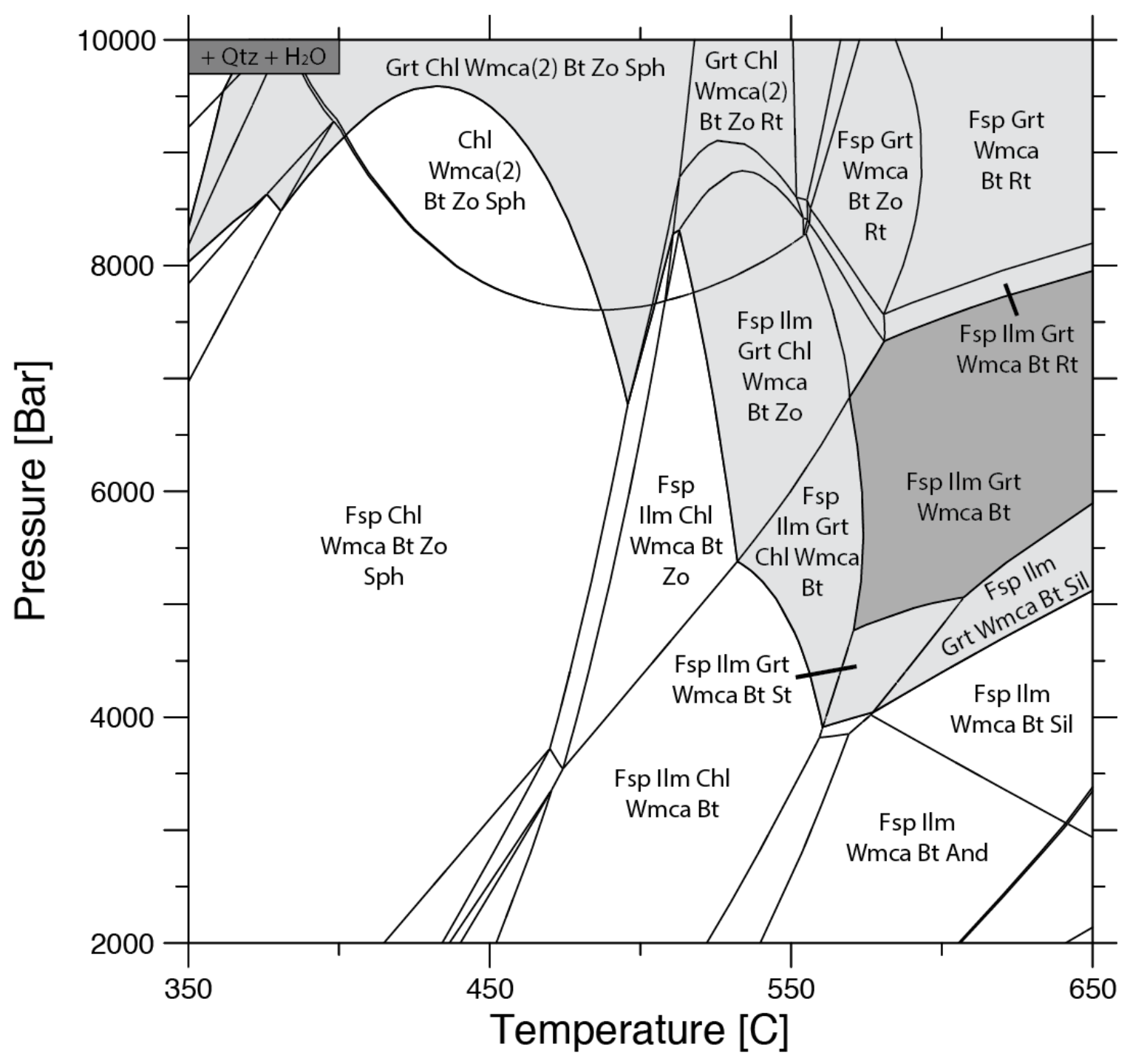

Figure 3.7.7 Phase equilibrium diagram for sample 00RAY098A. 


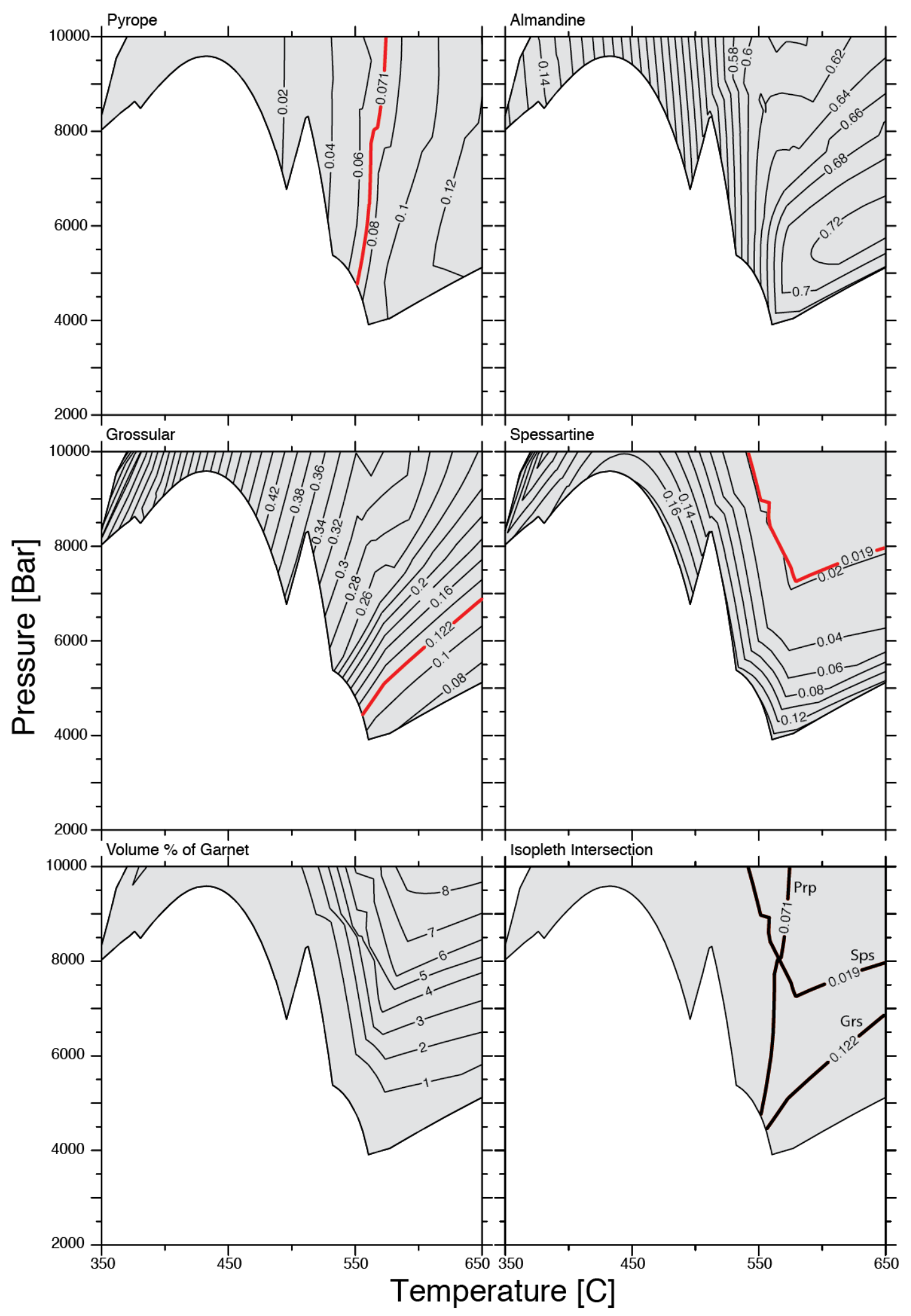

Figure 3.7.8 Garnet end-member isopleths for sample 00RAY098A. 
Sample 00RAY231A contains a peak assemblage field ranging from 575 to $700{ }^{\circ} \mathrm{C}$ and from 5.2 to $7.2 \mathrm{kbar}$ (Figure 3.7.9). The high $\mathrm{MnO}$ content in this rock results in garnetbearing assemblages being stable across the majority of the defined P-T field for this rock. Garnet core isopleths intersect at approximately $620^{\circ} \mathrm{C}$ and $4.5 \mathrm{kbar}$, but are unlikely to be representative of initial garnet growth conditions due to the relatively homogeneous chemical profile of garnet indicative of significant diffusional relaxation in this sample (Figure 3.7.10).

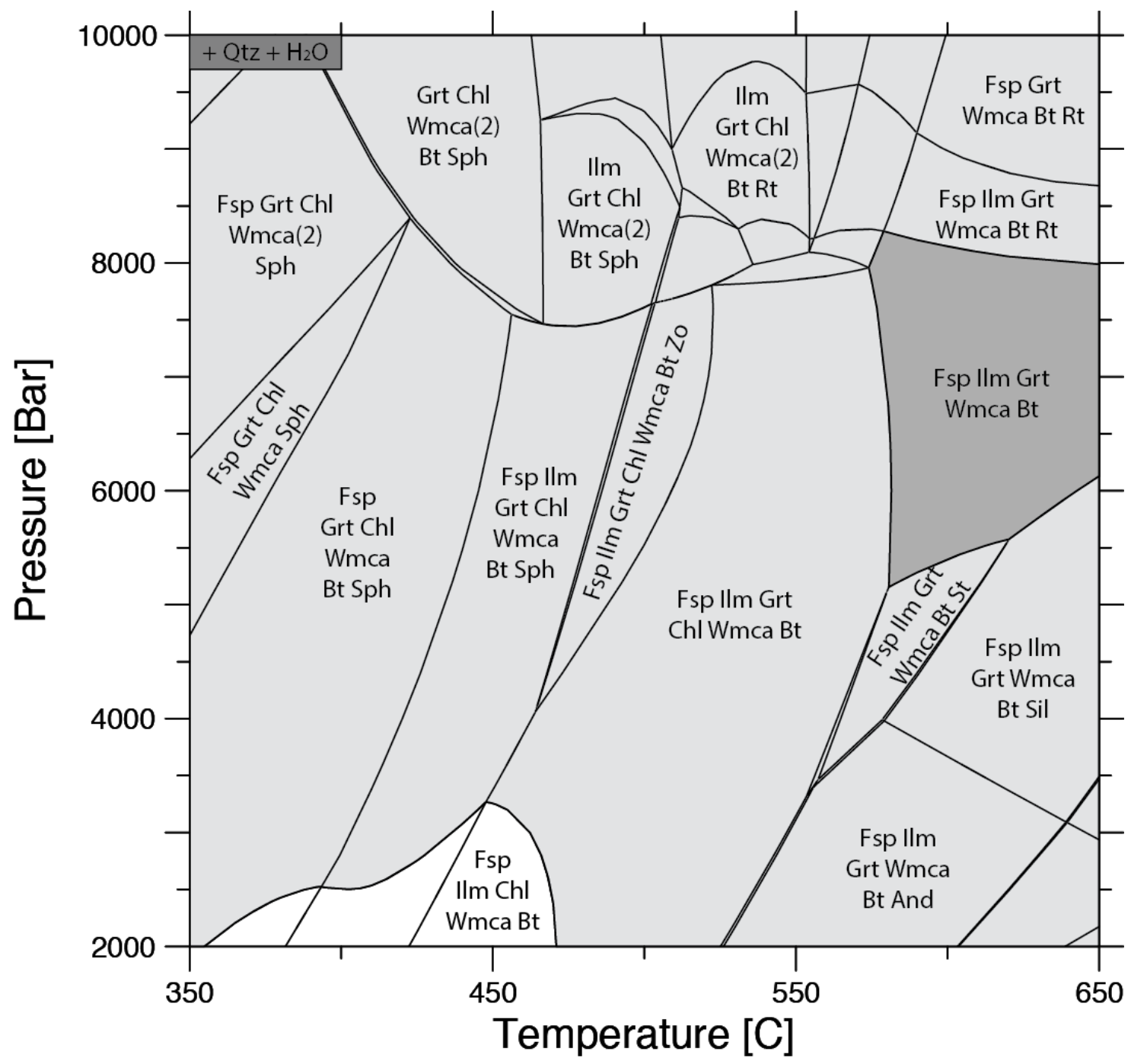

Figure 3.7.9 Phase equilibrium diagram for sample 00RAY231A. 


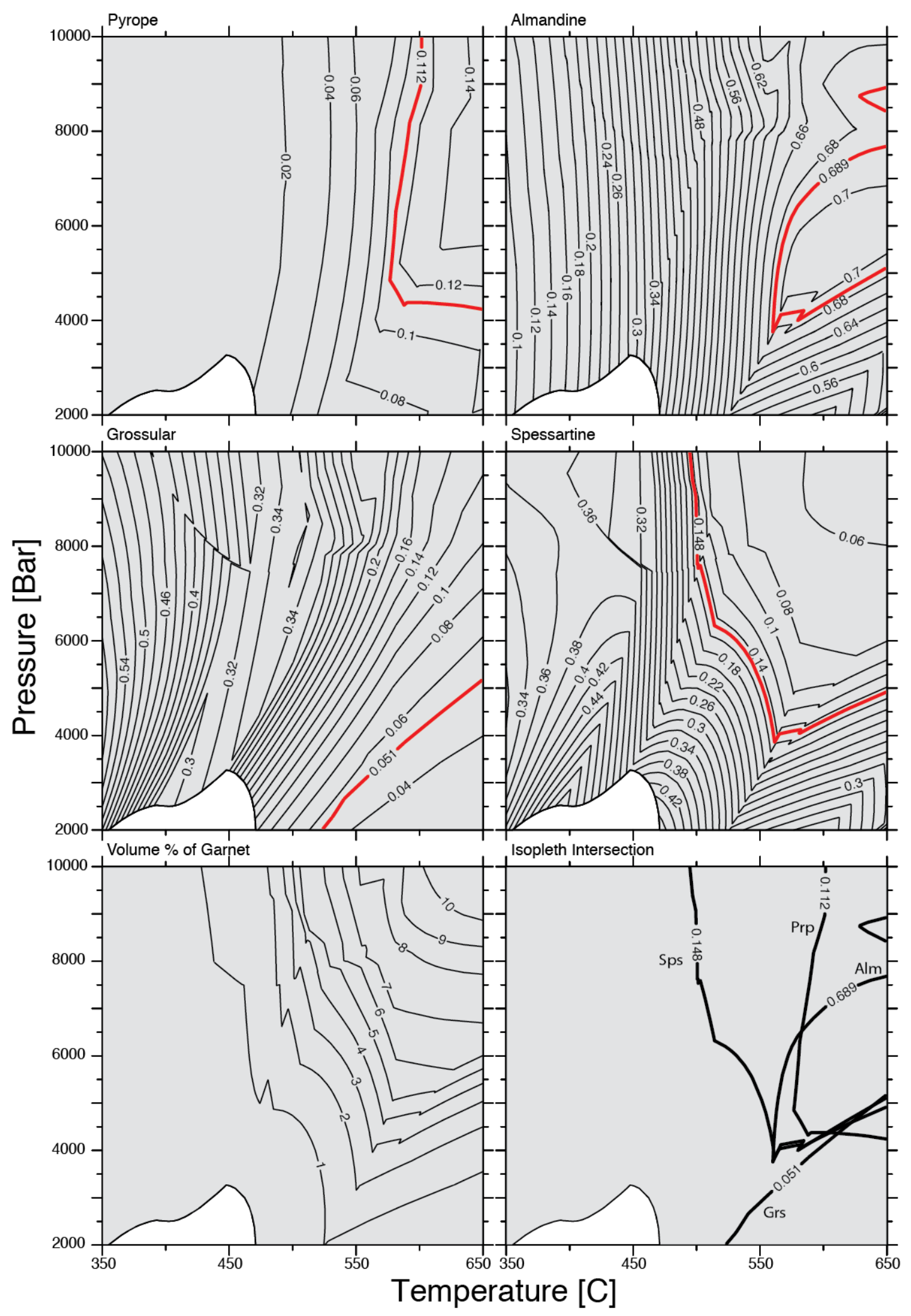

Figure 3.7.10 Garnet end-member isopleths for sample 00RAY231A. 
Sample 11RAYJR070A contains a peak assemblage predicted to form between 600 and $700{ }^{\circ} \mathrm{C}$, and above $7 \mathrm{kbar}$ (Figure 3.7.11). Garnet core isopleth intersections were not identified due to the garnet compositional profile not being symmetrical and not having an evident core position.

Sample 10RAYJR049A does not contain a mineral assemblage that matches any of the predicted assemblage fields for the P-T range modeled (Figure 3.7.12). The observed peak assemblage field is only displayed amongst a whole rock chemistry in which garnet is fractionated out. Core isopleths are not identified due to both compositional profiles representing garnet clusters rather than individual garnet crystals, and due to resulting uncertainties of the proximity of each crystal to their geometric center. 


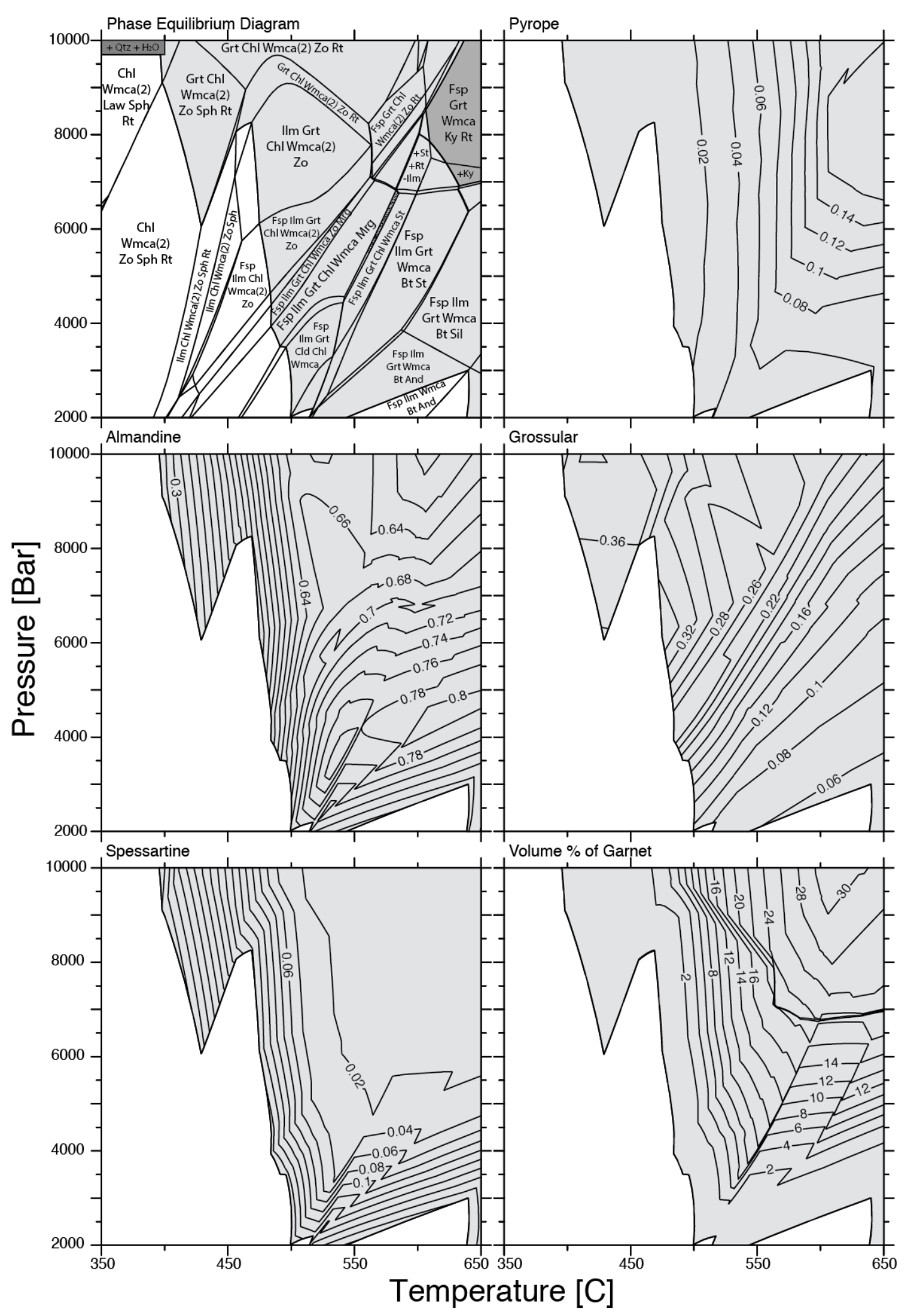

Figure 3.7.11 Phase equilibrium assemblage diagram and garnet end-member isopleths for sample 11RAYJR070A. 


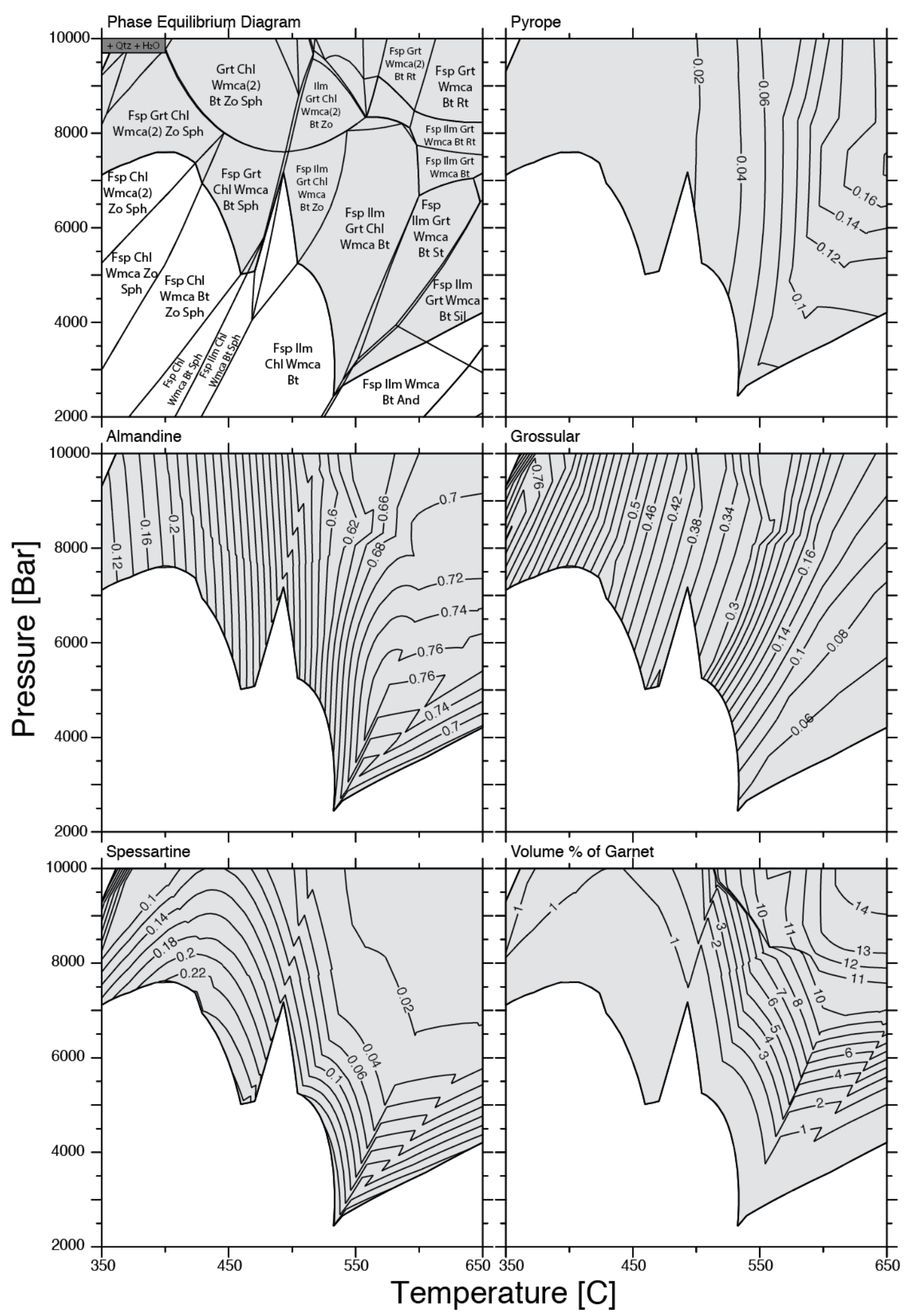

Figure 3.7.12 Phase equilibrium assemblage diagram and garnet end-member isopleths for sample 10RAYJR049A. 


\subsection{Age-Dating}

The Lu-Hf and Sm-Nd isotope data is presented in tables 3.8.1 and 3.8.2 for garnet and whole rock measurements of samples 15RAYJR246A, 00RAY098A and 00RAY231A. The garnet-whole rock Lu-Hf isochron for sample 15RAYJR246A indicates a garnet crystallization age of $192.2 \pm 7.2 \mathrm{Ma}$ with an initial ${ }^{176} \mathrm{Hf} /{ }^{177} \mathrm{Hf}$ ratio of $0.282165 \pm$ 0.000095 and a mean squared weighted deviation (MSWD) of 7.6 (Figure 3.8.1). The garnet-whole rock Sm-Nd isochron for this sample indicates an age of $197 \pm 11 \mathrm{Ma}$, with an initial ${ }^{143} \mathrm{Nd} /{ }^{144} \mathrm{Nd}$ ratio of $0.511156 \pm 0.000010$ and a MSWD of 1.7 (Figure 3.8.2).

For sample 00RAY098A, the garnet-whole rock Lu-Hf isochron yields an age of $188 \pm$ $21 \mathrm{Ma}$, an initial ${ }^{176} \mathrm{Hf} /{ }^{177} \mathrm{Hf}$ ratio of $0.282015 \pm 0.000090$, and a MSWD of 32 (Figure 3.8.3) for the core crystallization. The Sm-Nd isochron indicates a garnet crystallization age of $172.7 \pm 2.3 \mathrm{Ma}$ with an initial ${ }^{143} \mathrm{Nd} /{ }^{144} \mathrm{Nd}$ ratio of $0.5111837 \pm 0.0000053$ and a MSWD of 0.068 (Figure 3.8.4) for the entire garnet crystallization.

Sample 00RAY231A has a garnet-whole rock Lu-Hf isochron that yields an age of $245.35 \pm 0.80 \mathrm{Ma}$. The initial ${ }^{176} \mathrm{Hf} /{ }^{177} \mathrm{Hf}$ ratio is $0.2824057 \pm 0.0000068$ and the MSWD is 1.16 (Figure 3.8.5). The Sm-Nd isochron yields and age of $239 \pm 110 \mathrm{Ma}$, with an initial ${ }^{143} \mathrm{Nd} /{ }^{144} \mathrm{Nd}$ ratio of $0.51163 \pm 0.00017$ and a MSWD of 3.9 (Figure 3.8.6). The large error from the Sm-Nd isochron age results from only 3 analytical points being considered. 
Table 3.8.1 Lu-Hf geochronology results. WR $=$ whole rock, $M S W D=$ mean standard weighted deviation.

\begin{tabular}{|c|c|c|c|c|c|c|c|c|c|c|}
\hline & Fraction & $\begin{array}{c}\text { Lu } \\
\text { ppm }\end{array}$ & $\begin{array}{c}\text { Hf } \\
\text { ppm }\end{array}$ & $\begin{array}{l}{ }^{176} \text { Lu/ } \\
{ }^{177} \mathrm{Hf}\end{array}$ & $2 \sigma$ & $\begin{array}{l}{ }^{176} \mathrm{Hf} / \\
{ }^{177} \mathrm{Hf}\end{array}$ & $2 \sigma$ & $\begin{array}{l}\text { Age } \\
\text { (Ma) }\end{array}$ & $\begin{array}{c}\text { Initial } \\
{ }^{176} \mathrm{Lu} /{ }^{177} \mathrm{Hf}\end{array}$ & MSWD \\
\hline \multirow[t]{4}{*}{ 15RAYJR246A } & Garnet 1 & 4.258 & 0.706 & 0.853388 & 0.004267 & 0.285215 & 0.000006 & \multirow{4}{*}{$\begin{array}{c}192.2 \pm \\
7.2\end{array}$} & \multirow{4}{*}{$\begin{array}{c}0.282165 \pm \\
0.000095\end{array}$} & \multirow{4}{*}{7.6} \\
\hline & Garnet 2 & 4.577 & 0.816 & 0.793684 & 0.003968 & 0.285011 & 0.000005 & & & \\
\hline & Garnet 3 & 4.105 & 0.700 & 0.829739 & 0.004149 & 0.285172 & 0.000005 & & & \\
\hline & WR & 0.406 & 1.122 & 0.051164 & 0.000256 & 0.282349 & 0.000007 & & & \\
\hline \multirow[t]{4}{*}{ O0RAY098A } & Garnet 1 & 2.533 & 1.348 & 0.265695 & 0.001328 & 0.282930 & 0.000005 & \multirow{4}{*}{$\begin{array}{c}188 \pm \\
21\end{array}$} & \multirow{4}{*}{$\begin{array}{c}0.282015 \pm \\
0.000090\end{array}$} & \multirow{4}{*}{32} \\
\hline & Garnet 2 & 2.381 & 1.203 & 0.279846 & 0.001399 & 0.283016 & 0.000004 & & & \\
\hline & Garnet 3 & 2.296 & 1.295 & 0.250866 & 0.001254 & 0.282900 & 0.000004 & & & \\
\hline & WR & 0.284 & 1.286 & 0.031192 & 0.000156 & 0.282125 & 0.000004 & & & \\
\hline \multirow[t]{4}{*}{ O0RAY231A } & Garnet 1 & 5.613 & 0.534 & 1.488892 & 0.007444 & 0.289257 & 0.000007 & \multirow{4}{*}{$\begin{array}{l}245.35 \\
\pm 0.80\end{array}$} & \multirow{4}{*}{$\begin{array}{c}0.2824057 \\
\pm \\
0.0000068\end{array}$} & \multirow{4}{*}{1.16} \\
\hline & Garnet 2 & 2.524 & 0.307 & 1.165089 & 0.005825 & 0.287759 & 0.000006 & & & \\
\hline & Garnet 3 & 4.654 & 0.445 & 1.481414 & 0.007407 & 0.289187 & 0.000006 & & & \\
\hline & WR & 0.506 & 0.814 & 0.087988 & 0.000440 & 0.282810 & 0.000006 & & & \\
\hline
\end{tabular}

Table 3.8.2 Sm-Nd geochronology results.

\begin{tabular}{|c|c|c|c|c|c|c|c|c|c|c|}
\hline & Fraction & $\begin{array}{c}\text { Sm } \\
\text { ppm }\end{array}$ & $\begin{array}{c}\text { Nd } \\
\text { ppm }\end{array}$ & $\begin{array}{l}{ }^{147} \mathrm{Sm} / \\
{ }^{144} \mathrm{Nd}\end{array}$ & $2 \sigma$ & $\begin{array}{c}{ }^{143} \mathrm{Nd} / \\
{ }^{144} \mathrm{Nd}\end{array}$ & $2 \sigma$ & $\begin{array}{l}\text { Age } \\
\text { (Ma) }\end{array}$ & $\begin{array}{c}\text { Initial } \\
{ }^{143} \mathrm{Nd} /{ }^{144} \mathrm{Nd}\end{array}$ & MSWD \\
\hline \multirow[t]{4}{*}{ 15RAYJR246A } & Garnet 1 & 1.3612 & 4.4423 & 0.185190 & 0.000103 & 0.511400 & 0.000007 & \multirow{4}{*}{$\begin{array}{c}197 \pm \\
11\end{array}$} & \multirow{4}{*}{$\begin{array}{c}0.511156 \pm \\
0.000010\end{array}$} & \multirow{4}{*}{1.7} \\
\hline & Garnet 2 & 1.3418 & 4.2824 & 0.189379 & 0.000093 & 0.511398 & 0.000008 & & & \\
\hline & Garnet 3 & 1.4855 & 5.0556 & 0.177587 & 0.000099 & 0.511382 & 0.000008 & & & \\
\hline & WR & 3.9126 & 20.9879 & 0.112668 & 0.000014 & 0.511302 & 0.000003 & & & \\
\hline \multirow[t]{4}{*}{ O0RAY098A } & Garnet 1 & 2.1204 & 2.7508 & 0.465924 & 0.000203 & 0.511710 & 0.000007 & \multirow{4}{*}{$\begin{array}{l}172.7 \\
\pm 2.3\end{array}$} & \multirow{4}{*}{$\begin{array}{c}0.5111837 \pm \\
0.0000053\end{array}$} & \multirow{4}{*}{0.068} \\
\hline & Garnet 2 & 2.1303 & 2.8837 & 0.446509 & 0.000297 & 0.511687 & 0.000010 & & & \\
\hline & Garnet 3 & 2.0348 & 2.4781 & 0.496300 & 0.000212 & 0.511745 & 0.000005 & & & \\
\hline & WR & 0.9952 & 4.6972 & 0.128048 & 0.000012 & 0.511328 & 0.000004 & & & \\
\hline \multirow[t]{3}{*}{ 00RAY231A } & Garnet 1 & 1.7532 & 3.8930 & 0.272235 & 0.000159 & 0.512068 & 0.000008 & \multirow{3}{*}{$\begin{array}{c}239 \pm \\
110\end{array}$} & \multirow{3}{*}{$\begin{array}{c}0.51163 \pm \\
0.00017\end{array}$} & \multirow{3}{*}{3.9} \\
\hline & Garnet 2 & 1.6372 & 3.4211 & 0.289287 & 0.000198 & 0.512082 & 0.000009 & & & \\
\hline & WR & 1.7089 & 8.8547 & 0.116655 & 0.000013 & 0.511817 & 0.000003 & & & \\
\hline
\end{tabular}




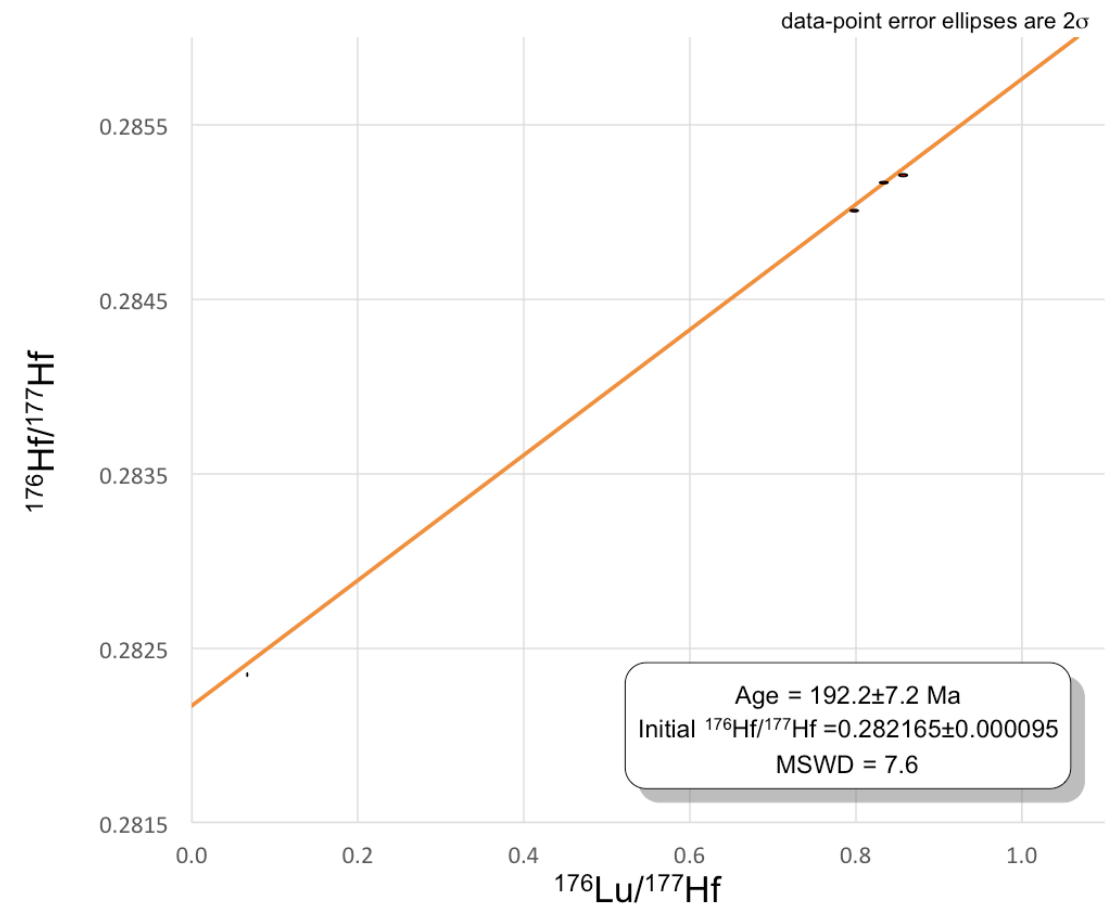

Figure 3.8.1 Lu-Hf garnet-whole rock isochron for sample 15RAYJR246A. MSWD = Mean squared weighted deviation.

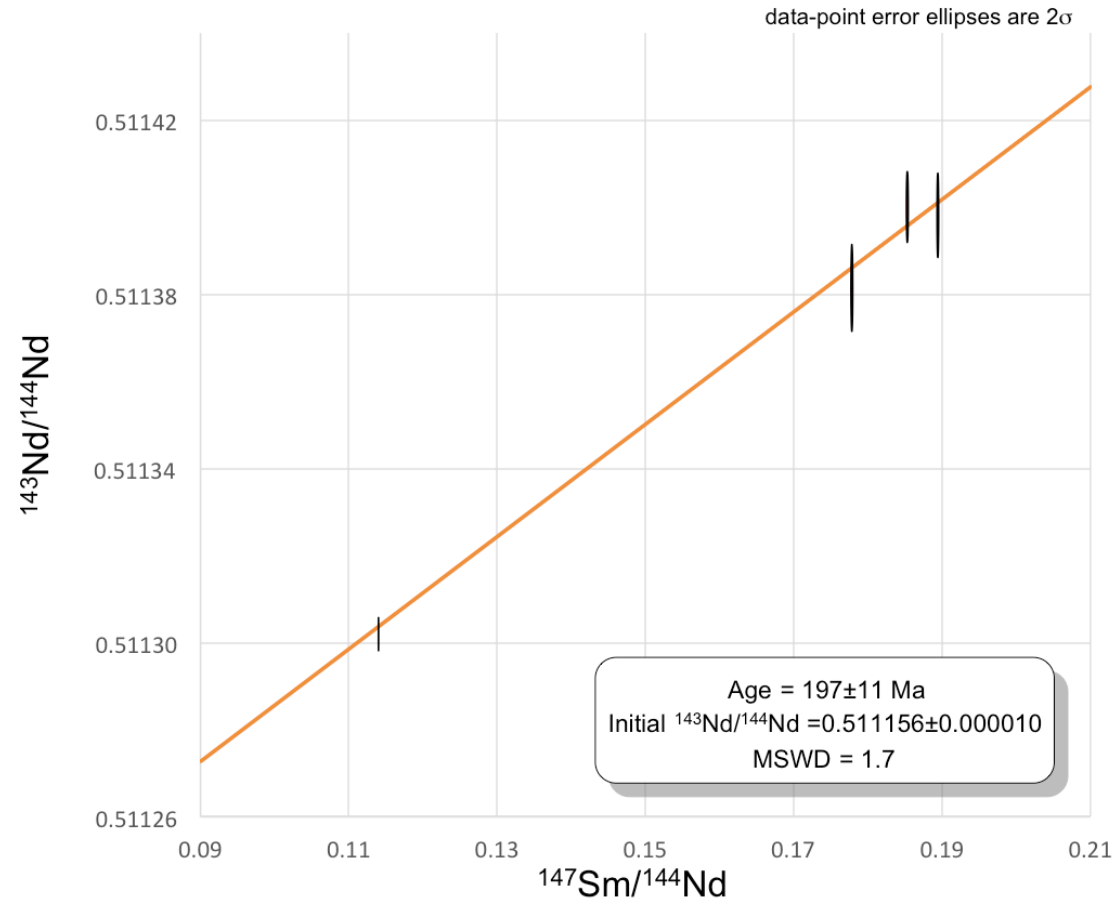

Figure 3.8.2 Sm-Nd garnet-whole rock isochron for sample 15RAYJR246A. 


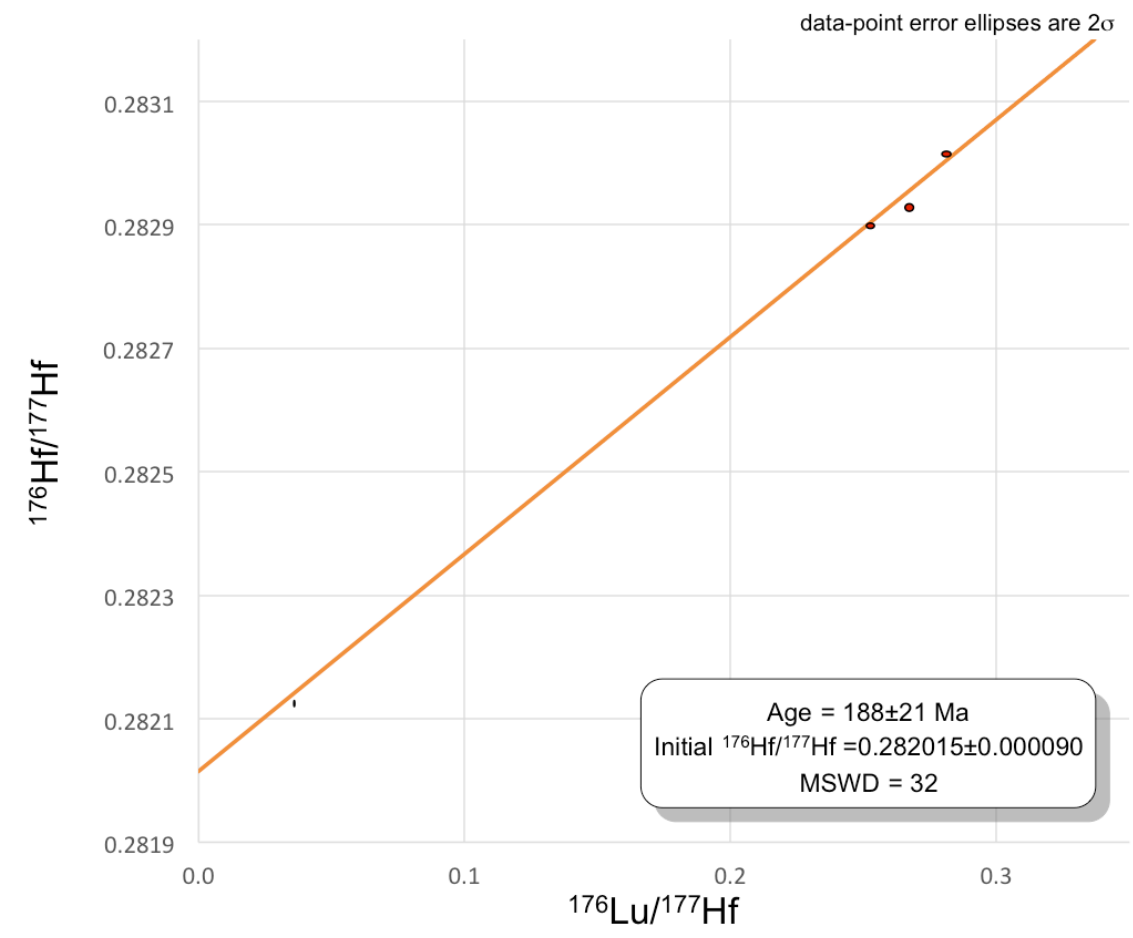

Figure 3.8.3 Lu-Hf garnet-whole rock isochron for sample 00RAY098A.

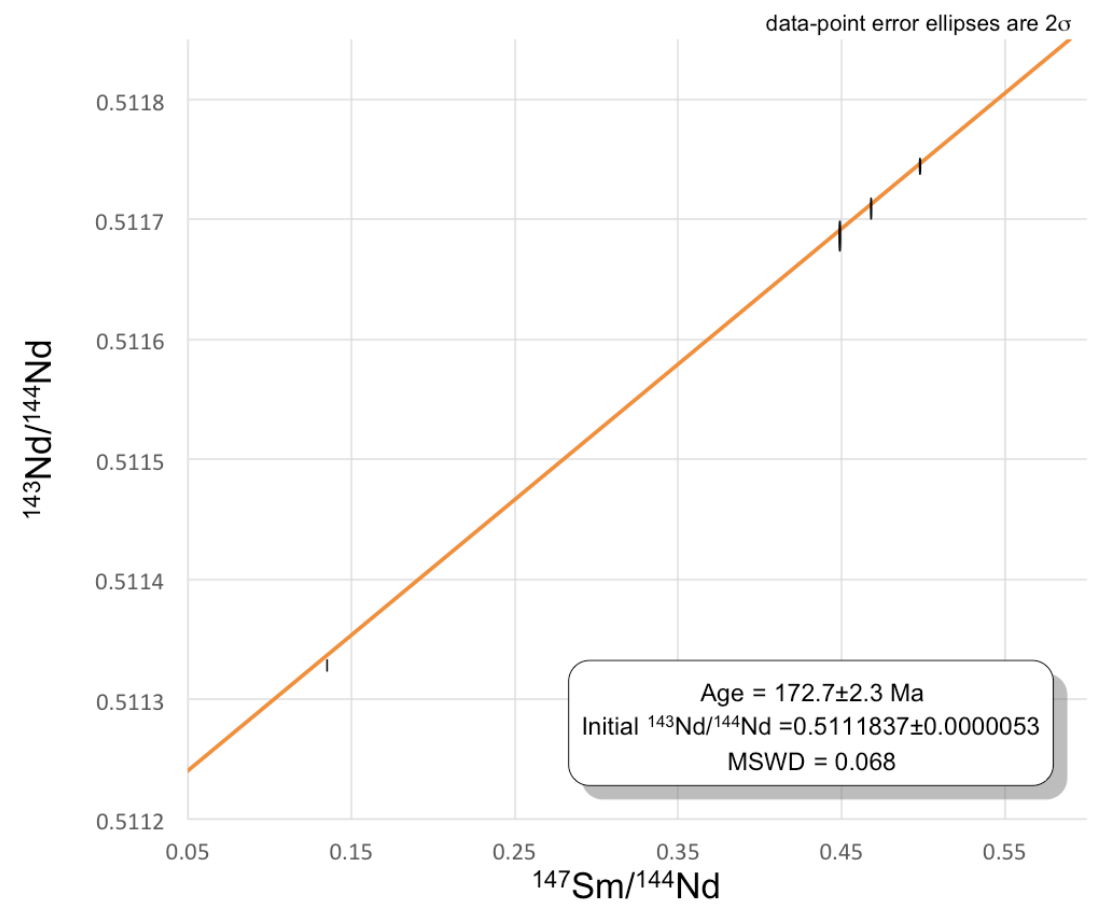

Figure 3.8.4 Sm-Nd garnet-whole rock isochron for sample 00RAY098A. 


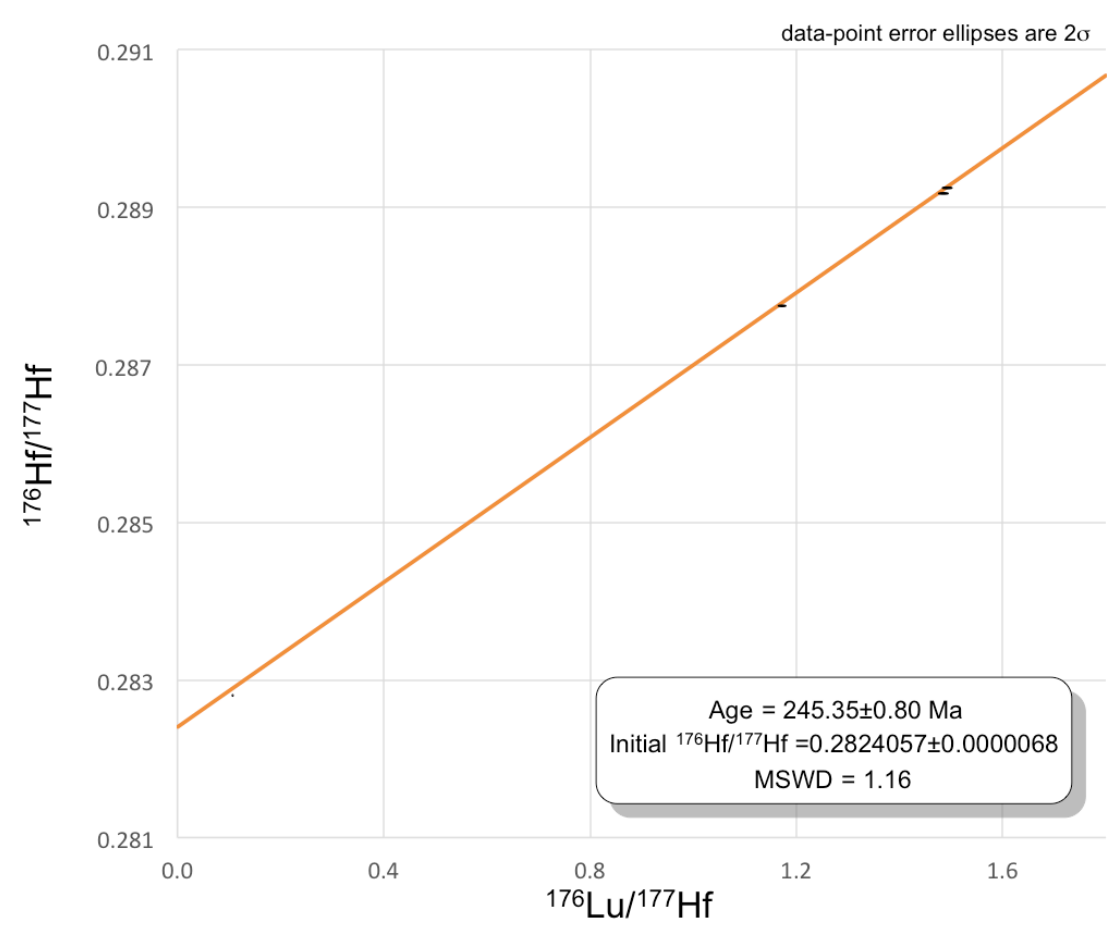

Figure 3.8.5 Lu-Hf garnet-whole rock isochron for sample 00RAY231A.

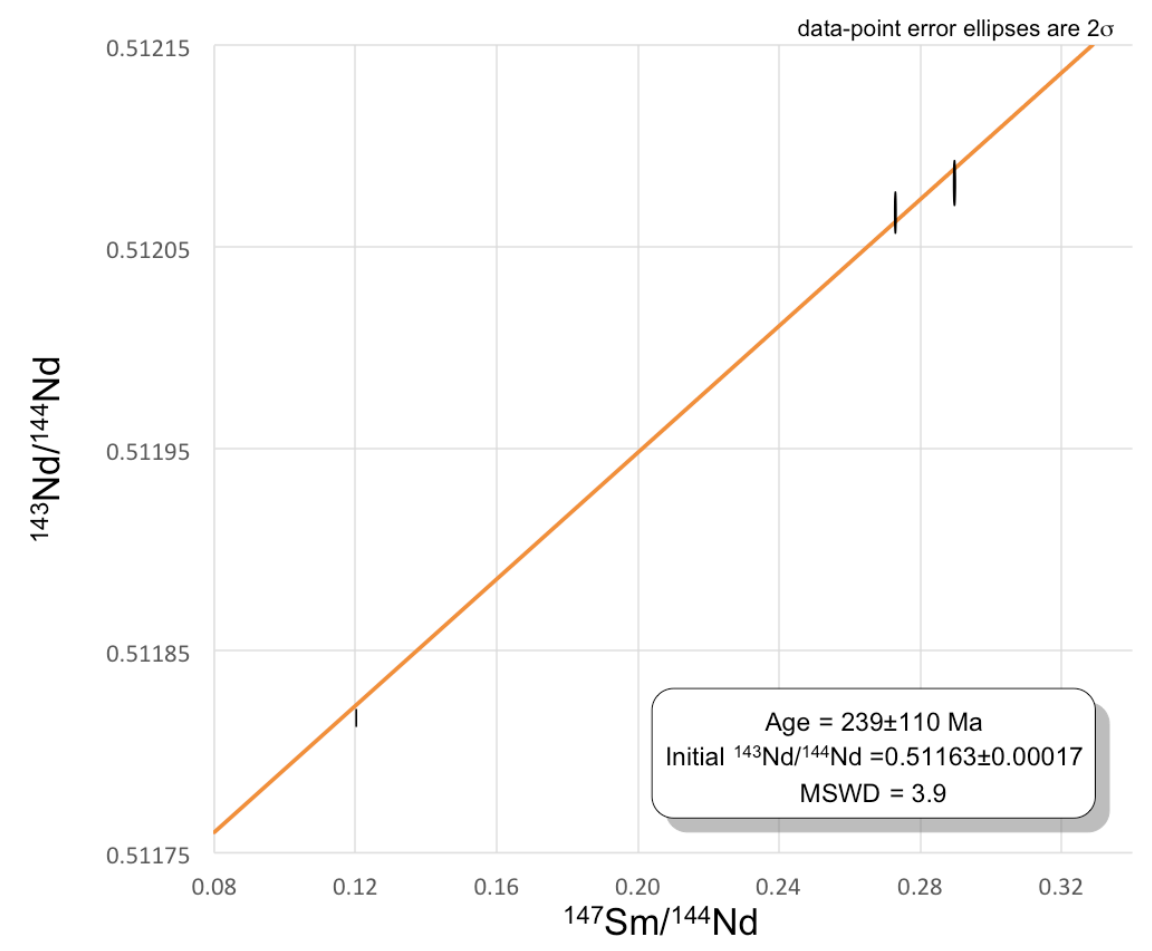

Figure 3.8.6 Sm-Nd garnet-whole rock isochron for sample 00RAY231A. 


\section{Chapter: Interpretations and Discussion}

\subsection{Sample Groups}

The samples collected for this study are divided into three regionally distinct groups (Table 3.1.1) that differ with respect to their microstructures, inclusion phases in garnet, presence of chlorite rims around garnet, presence of polyphase garnet crystals, bulk chemistry relative to pelites and psammites of the Snowcap assemblage (Piercey and Colpron, 2009), garnet crystal size distribution, and level of chemical relaxation observed in garnet cores (Table 4.1.1). The NW group, located in the north-west part of the study area (Figure 4.1.1), is distinguished by the presence of preserved $\mathrm{S}_{\mathrm{M}-1}$ crenulation cleavage (Figure 3.2.2), abundant quartz and ilmenite inclusion trails in garnet (Figure 3.2.1), frequent presence of chlorite rims, and a normal distribution of garnet crystal sizes (Figures 3.4.1a, b). The central group, located south-east of the NW group, is distinguished by inclusion trails in garnet composed of only ilmenite (Figure 3.2.3), presence of polyphase garnet crystals, and relatively high diffusional relaxation levels in garnet cores (Figure 3.5.2). Whole rock compositions for all samples in the NW and central groups are similar and fall within similar ranges as previously studied metapelites and metapsammites of the Snowcap Assemblage outside of the Stewart River area (Table 4.1.2; Piercey and Colpron, 2009). The Scroggie Creek group, located east of the central group, adjacent to the Scroggie Creek pluton, is distinguished by its different bulk chemistry. Samples from Scroggie Creek group have distinctively lower $\mathrm{SiO}_{2}$ contents, and higher $\mathrm{Al}_{2} \mathrm{O}_{3}, \mathrm{Fe}_{2} \mathrm{O}_{3}, \mathrm{TiO}_{2}, \mathrm{P}_{2} \mathrm{O}_{5}, \mathrm{Sr}$, Sc and $\mathrm{V}$ contents compared to other samples (Table 4.1.2), indicating a shale to Fe-shale protolith and an active continental margin to oceanic island arc depositional environment (Figures 3.3.2 and 3.3.3). The higher 
aluminum content in these rocks stabilizes abundant alumino-silicates (Figure 3.2.4).

The distinct bulk chemistry suggests that samples from Scroggie Creek group were either chemically altered prior to or during metamorphism, or they represent a different tectonic unit with an arc continental margin or oceanic island arc depositional setting (Figure 3.3.3)

Table 4.1.1 Group similarities and differences. Shaded cells correspond to distinguishing features for corresponding group.

\begin{tabular}{|l|c|c|c|}
\cline { 2 - 4 } \multicolumn{1}{c|}{} & NW & Central & Scroggie Creek \\
\hline $\mathrm{S}_{\mathrm{M}}$ (Schistosity) & $\checkmark$ & $\checkmark$ & $\checkmark$ \\
\hline $\mathrm{S}_{\mathrm{M}-1}$ (Crenulation Cleavage) & $\checkmark$ & $x$ & $x$ \\
\hline $\mathrm{S}_{\mathrm{M}-2}$ (Foliation) & $\checkmark$ & $\checkmark$ & $\begin{array}{c}\text { Observed by } \\
\text { Berman et al., } \\
(2007)\end{array}$ \\
\hline Inclusions forming trails & Qtz + Ilm & Ilm & N/A \\
\hline Presence of chlorite rims around garnet & $\begin{array}{c}\text { Abundant } \\
\text { Not } \\
\text { Observed }\end{array}$ & $\begin{array}{c}\text { Not abundant } \\
\text { Observed in 2 } \\
\text { samples }\end{array}$ & Not observed \\
\hline Polyphase garnet crystals & $x$ & $x$ & $\checkmark$ \\
\hline Presence of alumino-silicates & Similar & Similar & Different \\
\hline $\begin{array}{l}\text { Bulk chemistry compared to pelites and } \\
\text { psammites of Piercey and Colpron (2009) }\end{array}$ & Normal & $\begin{array}{c}\text { Positively } \\
\text { skewed }\end{array}$ & Positively skewed \\
\hline CSD & Moderate & High & Low to moderate \\
\hline Level of chemical relaxation in garnet core
\end{tabular}




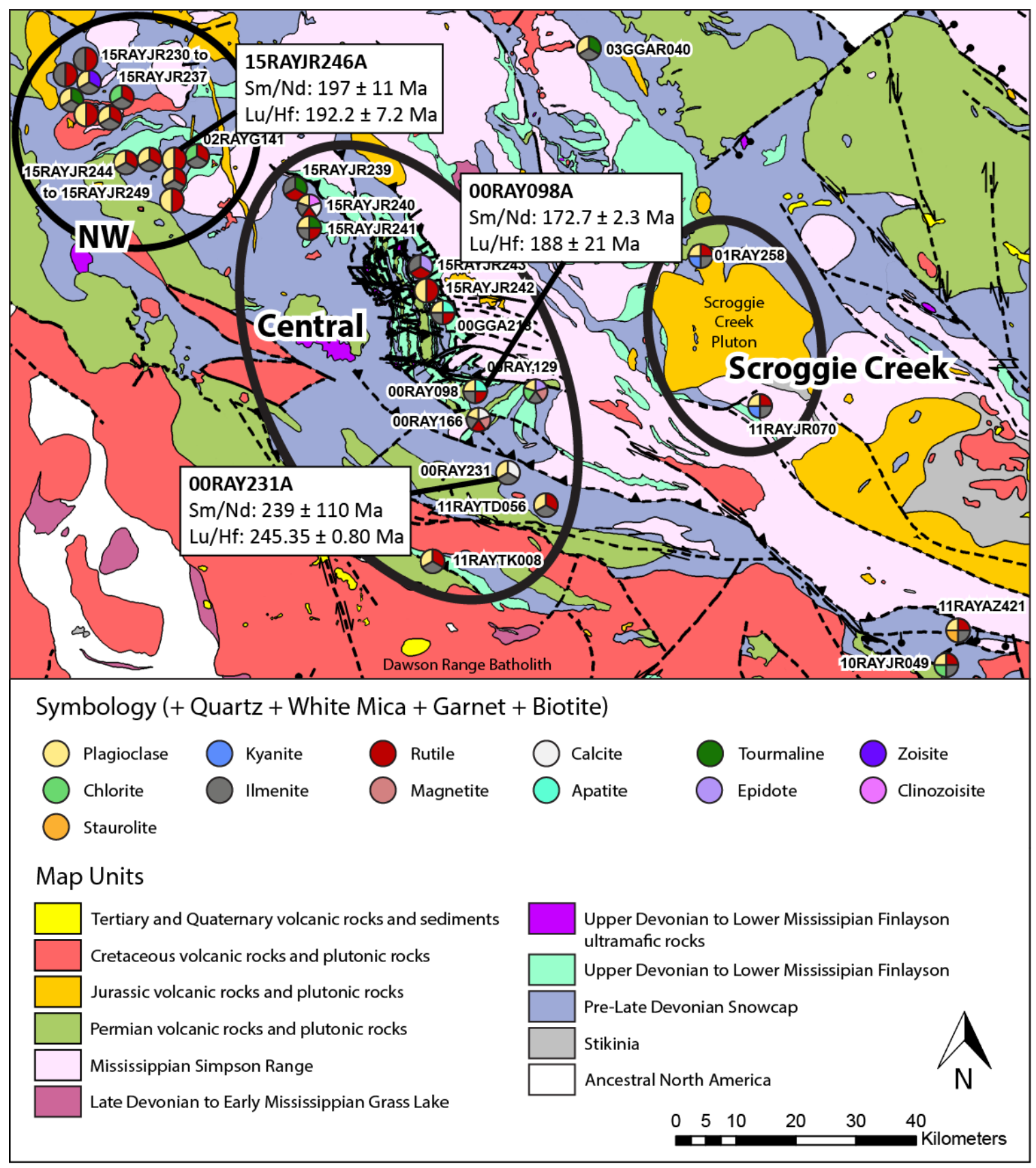

Figure 4.1.1 Map of the study area containing the mineralogy, groups and geochronology results. 
\begin{tabular}{ll} 
Table 4.1.2 Group comparison for ranges of whole rock composition. \\
\hline
\end{tabular}

\begin{tabular}{|l|c|c|c|c|c|}
\hline Component & NW & Central & $\begin{array}{c}\text { Scroggie } \\
\text { Creek }\end{array}$ & Other Samples & Piercey \& Colpron (2009) \\
\hline $\mathrm{SiO}_{2}$ (wt.\%) & $54-75$ & $53-75$ & $41-48$ & $56-61$ & $55-80$ \\
\hline $\mathrm{Al}_{2} \mathrm{O}_{3}$ & $11-23$ & $11-23$ & $25-36$ & $18-21$ & $9-23$ \\
\hline $\mathrm{Fe}_{2} \mathrm{O}_{3}$ & $3-10$ & $4-11$ & $11-14$ & $7-10$ & $2-10$ \\
\hline $\mathrm{MnO}$ & $0.02-0.19$ & $0.01-0.35$ & $0.16-0.18$ & $0.10-0.20$ & $0.03-0.75$ \\
\hline $\mathrm{MgO}$ & $1.3-2.7$ & $1.3-3.5$ & $0.9-1.8$ & $2.5-2.9$ & $0.8-3.2$ \\
\hline $\mathrm{CaO}$ & $0.2-2.8$ & $0.1-3.2$ & $0.9-3.3$ & $0.5-1.3$ & $0.3-9$ \\
\hline $\mathrm{Na}_{2} \mathrm{O}$ & $0.3-2.1$ & $0.3-2$ & $1.3-2.8$ & $0.9-1.3$ & $0.7-3$ \\
\hline $\mathrm{K}_{2} \mathrm{O}$ & $2.5-5.7$ & $2.1-6.7$ & $1.4-3.4$ & $3.7-5.3$ & $1.4-9$ \\
\hline $\mathrm{TiO}_{2}$ & $0.57-0.95$ & $0.23-1.41$ & $1.66-1.86$ & $0.88-1.47$ & $0.37-1.27$ \\
\hline $\mathrm{P}_{2} \mathrm{O}_{5}$ & $0.07-0.26$ & $0.03-0.26$ & $0.18-1.63$ & $0.08-0.11$ & $0.04-0.33$ \\
\hline $\mathrm{Ba}(p p m)$ & $600-2600$ & $600-2800$ & $500-2300$ & $1000-1100$ & $300-1500$ \\
\hline $\mathrm{Sr}$ & $30-240$ & $60-250$ & $280-460$ & $60-180$ & $50-220$ \\
\hline $\mathrm{Y}$ & $17-35$ & $15-39$ & $17-40$ & $22-33$ & $16-33$ \\
\hline $\mathrm{Sc}$ & $9-22$ & $12-28$ & $29-57$ & $20-22$ & $6-23$ \\
\hline $\mathrm{Zr}$ & $90-300$ & $100-340$ & $230-330$ & $220-360$ & $110-270$ \\
\hline $\mathrm{V}$ & $17-200$ & $<5-160$ & $180-280$ & $110-140$ & $36-120$ \\
\hline
\end{tabular}

Samples 03GGAR040, 10RAYJR049 and 11RAYAZ421 are not included in any groups due to their isolated locations and differences in textures and mineralogy compared to the other groups. Their bulk rock chemistry matches those of the NW and Central groups indicating that they are from the same tectonic assemblage. These samples were not amenable to further modeling.

\subsection{Uncertainties in Thermodynamic Modeling}

The thermodynamic database contains multiple uncertainties that must be considered during interpretation of results. An uncertainty that affects all equilibrium assemblage and garnet crystallization results is associated with the chemical model system used to represent the whole rock composition. In this study, the use of a $\mathrm{TiO}_{2}-\mathrm{MnO}-\mathrm{CaO}-\mathrm{Na}{ }_{2} \mathrm{O}-$ 
$\mathrm{K}_{2} \mathrm{O}-\mathrm{FeO}-\mathrm{MgO}-\mathrm{Al}_{2} \mathrm{O}_{3}-\mathrm{SiO}_{2}-\mathrm{H}_{2} \mathrm{O}$ system does not consider every component possibly present in the rocks. For example, apatite is not predicted due to phosphorous not being considered. Similarly, tourmaline is not modeled due to boron not being considered.

An additional uncertainty in the thermodynamic database affecting samples of this study is the inefficient prediction of the distribution and occurrence of Ti-bearing mineral phases. Sphene is often predicted as the major Ti-bearing mineral at $\mathrm{T}<500{ }^{\circ} \mathrm{C}$ (Figures 3.7.1, 3.7.3, 3.7.5, 3.7.7, 3.7.9, 3.7.11, and 3.7.12), but there is no observed sphene growth evidence to support the formation of sphene. Ilmenite forming rims around rutile in the matrix and in garnet inclusions in sample 15RAYJR246A (Figures 3.6.2g, h) suggests the formation of rutile prior to ilmenite along the prograde P-T path. This needs to be taken into consideration as rutile-bearing assemblages in phase equilibrium modeling of these samples is predicted at $\mathrm{P}>7-9 \mathrm{kbar}$, where rutile replaces ilmenite. The presence of rutile must therefore be carefully considered as it may not always be a high $\mathrm{P}$ indicator.

The behavior of garnet and corresponding distribution of end-member contents at low P$\mathrm{T}$ conditions in Mn-rich pelitic rocks may be an additional uncertainty. Working with rocks of this composition is problematic due to the composition of garnet not being properly predicted, causing garnet crystallization modeling to be inaccurate. This mostly affects sample 00RAY231A in this study, which has a $\mathrm{MnO}$ whole-rock content of 0.344 wt.\% (Table 3.3.1). This content is significantly higher than for the average metapelite, which is 0.07 wt.\% (Symmes and Ferry, 1991). In comparison, sample 00RAY098A 
contains a lower $\mathrm{MnO}$ content of $0.044 \mathrm{wt} \%$, and therefore has a garnet-in reaction occurring at significantly higher P-T conditions (e.g. $>4$ kbar and $525^{\circ} \mathrm{C}$; Figure 3.7.7) then sample 00RAY231A (e.g. $<3.5 \mathrm{kbar}$ and $475^{\circ} \mathrm{C}$; Figure 3.7.9).

\subsection{Peak Metamorphic Conditions and P-T-t Path Reconstruction}

Phase equilibrium modeling conducted on all 36 samples resulted in peak metamorphic T ranging between 500 and $700{ }^{\circ} \mathrm{C}$, and $\mathrm{P}$ ranging from less than $2 \mathrm{kbar}$ to more than 10 kbar (Figure 4.3.1). Assuming that all samples went through similar peak conditions, the overlap between these fields refine the peak conditions to be between approximately 600 and $700{ }^{\circ} \mathrm{C}$, and 7 and $9.5 \mathrm{kbar}$. The peak assemblage fields overlap for all samples across all groups with no regional differences. Garnet crystallization modeling was used to further refine the peak P-T conditions and to identify a high precision P-T-t path for samples of the NW and central groups. Asymmetrical garnet compositional profiles make samples 10RAYJR049 and 11RAYJR070 amenable to modeling due to the assumption that garnet grows at an equal rate in all directions. Each end-member should be consumed equally in all directions from the nucleation point of the crystal, forming either a negative or positive peak at the nucleation point. The asymmetry in the garnet crystals of these samples prevents the identification of the chemical core that corresponds to the nucleation point. 


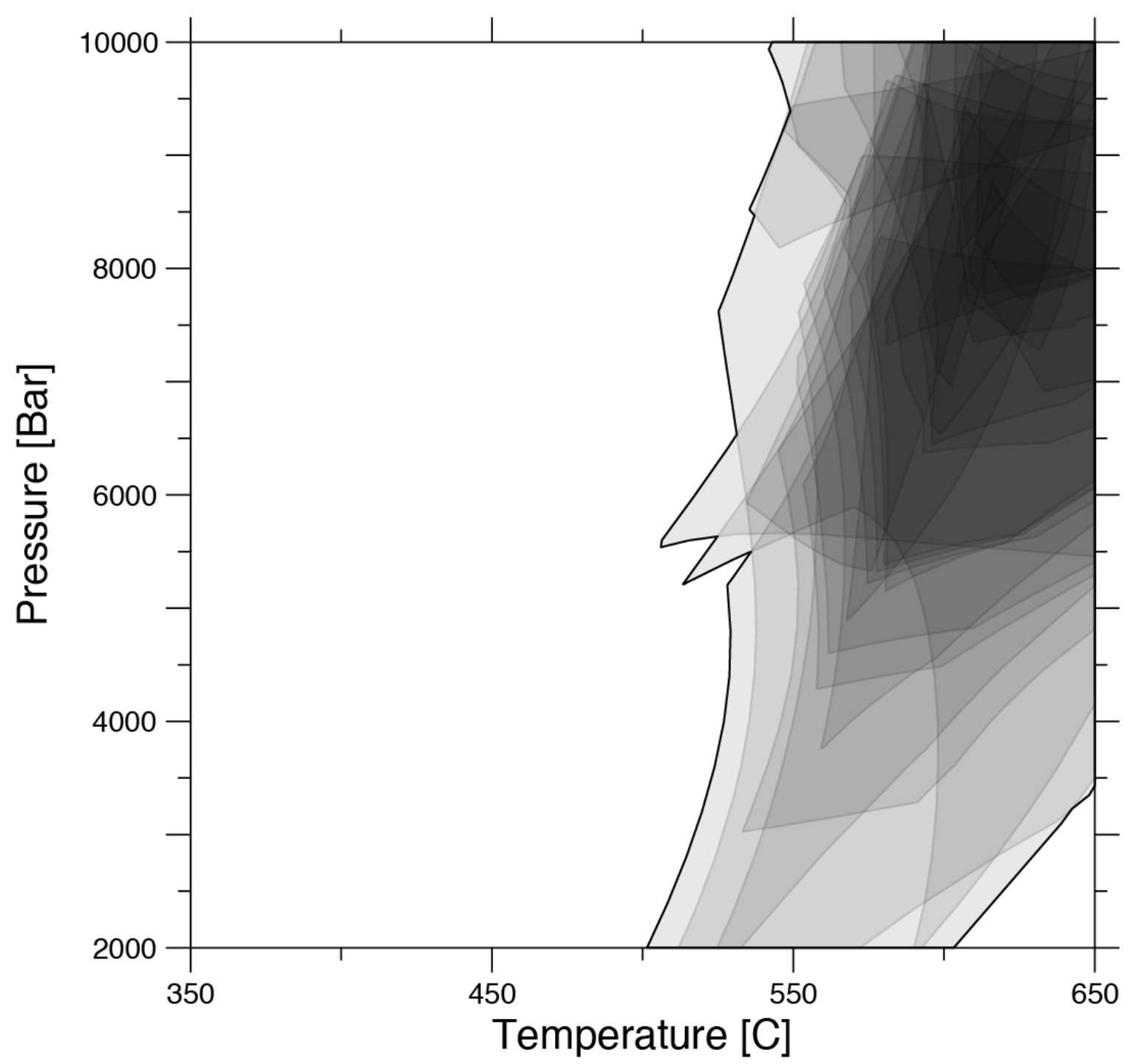

Figure 4.3.1 Peak mineral assemblage fields for all samples. Darker areas correspond to more common areas where peak mineralogy overlaps. There are no regional distinctions in peak P-T fields. The most common area matches approximately $8 \mathrm{kbar}$ and $620^{\circ} \mathrm{C}$.

For samples modeled, phase equilibrium diagrams displaying respective P-T-t paths are calculated using the fractionated rock chemistry at the end of garnet growth along the PT-t path displayed. Table 4.3.1 contains the fractionated rock compositions used for the construction of each diagram. The P-T-t path was reconstructed by modeling the growth and composition of garnet while considering the crystal size distribution of garnet. The 
CSD indicates the number of new garnet nucleation sites that is required at given steps along the P-T-t path, which is necessary to accurately predict the chemical composition and volume of garnet along the path. The crystal size and grossular compositional profile of the largest garnet were used as a reference points to determine the direction and end of the P-T path of garnet crystallization (Figures 3.5.1 and 3.5.2).

Table 4.3.1 Fractionated whole rock elemental composition post garnet growth in mol \%. "?" values for $\boldsymbol{O}$ corresponds to the amount of $\boldsymbol{O}$ required for charge balance in the system, and is calculated by the software.

\begin{tabular}{|c|c|c|c|c|c|c|c|c|c|c|c|}
\hline Sample \# & $\mathbf{K}$ & $\mathbf{F e}$ & $\mathbf{M g}$ & $\mathbf{A l}$ & $\mathbf{S i}$ & $\mathbf{H}$ & $\mathbf{C a}$ & $\mathbf{M n}$ & $\mathbf{N a}$ & $\mathbf{T i}$ & $\mathbf{0}$ \\
\hline $\begin{array}{c}\text { 15RAYJR237B } \\
\text { Figure 4.3.2 }\end{array}$ & 3.96 & 2.113 & 2.345 & 15.33 & 67.81 & 75 & 0.112 & 0.0000 & 0.84 & 0.60 & $?$ \\
\hline $\begin{array}{c}\text { 15RAYJR246A } \\
\text { Figure 4.3.5 }\end{array}$ & 7.3 & 3.647 & 2.951 & 21.73 & 52.34 & 75 & 0.478 & 0.0030 & 1.14 & 0.62 & $?$ \\
\hline $\begin{array}{c}\text { 00RAY098A - } \\
\text { Post-phase 1 } \\
\text { Figure 4.3.7 }\end{array}$ & 7.41 & 5.455 & 4.557 & 22.75 & 55.64 & 75 & 1.321 & 0.0184 & 1.42 & 0.48 & $?$ \\
\hline $\begin{array}{c}\text { 00RAY098A - } \\
\text { Post-phase 2 } \\
\text { Figure 4.3.10 }\end{array}$ & 7.41 & 5.065 & 4.508 & 22.47 & 55.23 & 75 & 1.229 & 0.0035 & 1.42 & 0.48 & $?$ \\
\hline $\begin{array}{c}\text { 00RAY231A } \\
\text { Figure 4.3.12 }\end{array}$ & 5.6 & 6.034 & 3.872 & 20.01 & 60.32 & 75 & 0.909 & 0.1817 & 1.87 & 0.72 & $?$ \\
\hline
\end{tabular}

A first uncertainty in garnet crystallization modeling comes from the presence of resorption affecting garnet crystals, which is not considered by the modeling. Garnet crystallization modeling assumes that all garnet crystals grow spherically and do not change in size post growth. Garnet resorption affects the chemical composition of the system and the garnet crystal sizes. The presence of chlorite rims around garnet, which is commonly observed in samples from the NW group, indicates the appearance of hydrating fluids during the retrograde path causing chlorite to form, and is a sign of chemical alteration. Garnet resorption is random, affecting each garnet crystal differently, and is not predictable with current methodology. 
A second uncertainty occurs post garnet growth while modeling intracrystalline diffusion using a dwell time, which is a period of time that the sample stays at peak T conditions prior to embarking on the retrograde path. The diffusion simulations done here are sensitive to both dwell time and peak $\mathrm{T}$, but cannot be used to distinguish between the individual influences of these parameters on garnet compositional zoning. Regional context or other methods must be considered to constrain the possible time and conditions.

\subsubsection{NW Group}

\section{RAYJR237B}

Garnet nucleation of the crystal analyzed occurred at P-T conditions of approximately $540{ }^{\circ} \mathrm{C}$ and $5.3 \mathrm{kbar}$ as indicated by isopleth thermobarometry of the largest garnet crystal core (Figure 3.7.2). A P-T path determined from iterative modeling of the grossular profile during garnet growth compared to the observed grossular profile starts garnet crystallization at P-T conditions of $528^{\circ} \mathrm{C}$ and $4.65 \mathrm{kbar}$, and reaches peak metamorphic conditions of $600{ }^{\circ} \mathrm{C}$ and 7 kbar (Table 4.3.2; Figures 4.3.2 and 3.5.1). The modeled compositional profiles for other garnet end-members and the predicted garnet CSD are best matched along this P-T path (Figure 4.3.3). Increases in peak temperatures in the model would be accompanied with the formation of staurolite and/or kyanite, which are both absent in the mineral assemblage. The formation of staurolite should be accompanied by a sharp decrease in almandine and increase in pyrope, neither of which are observed in the garnet compositional profile. The modeling predicts garnet growth in a mineral assemblage that does not include rutile until peak P-T conditions of $600{ }^{\circ} \mathrm{C}$ and 
$7 \mathrm{kbar}$ are reached, where rutile becomes stable, which is supported by the presence of rutile in the matrix and its absence as garnet inclusions. No additional changes in the mineral assemblage are predicted.

Table 4.3.2 Modeled P-T-t path of sample 15RAYJR237B.

\begin{tabular}{|c|c|c|c|}
\hline Temperature $\left({ }^{\circ} \mathbf{C}\right)$ & Pressure (bar) & Time (My) & Heating/Cooling Rate $\left({ }^{\circ} \mathbf{C} / \mathbf{M y}\right)$ \\
\hline 528 & 4650 & 0 & 20 \\
\hline 550 & 4650 & 1.1 & 20 \\
\hline 565 & 5000 & 1.85 & 20 \\
\hline 595 & 6850 & 3.35 & 20 \\
\hline 600 & 7000 & 103.35 & 0.05 \\
\hline
\end{tabular}

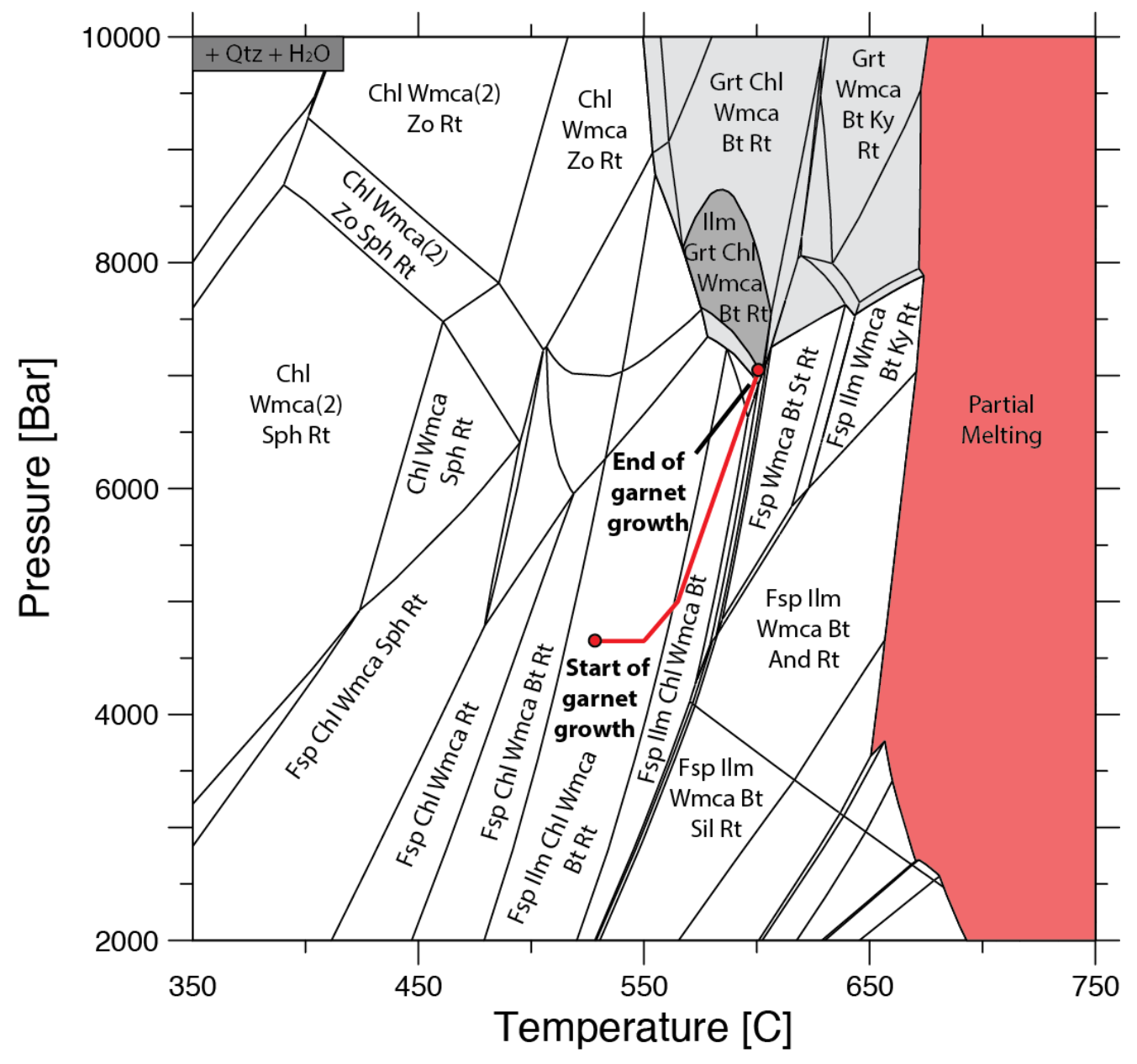

Figure 4.3.2 P-T path of sample 15RAYJR237B. Phase equilibrium diagram is modeled with the fractionated whole rock chemistry at the end of the garnet growth. 


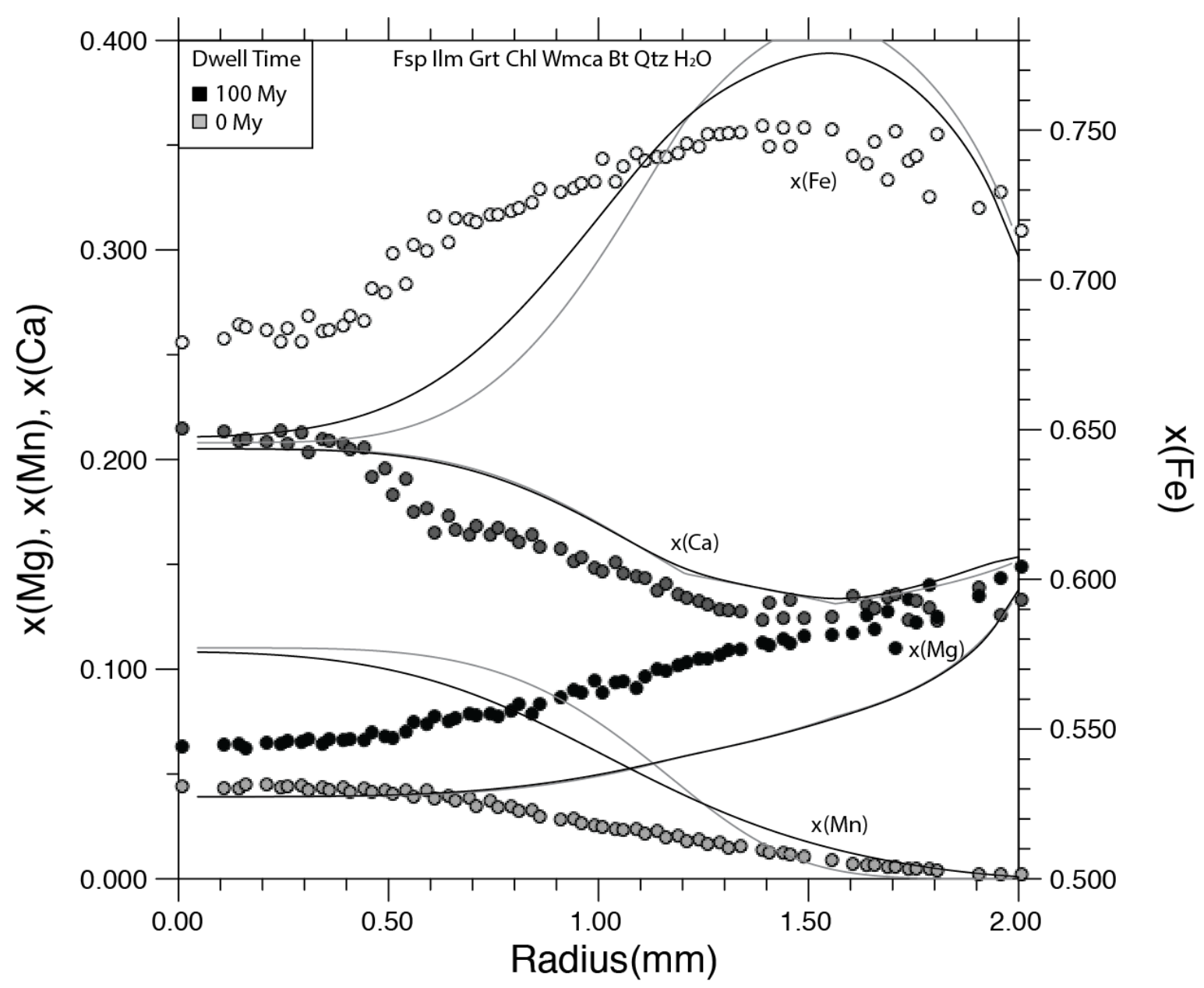

Figure 4.3.3 Modeled garnet compositional profiles for sample 15RAYJR237B. Profiles represent garnet growth along the same path with various dwell periods at peak $T$.

Modeled xFe content in the core is approximately 0.04 lower than observed, and 0.04 higher than observed at the peak, located at a distance of $1.5 \mathrm{~mm}$ from the core (Figure 4.3.3). The modeled pyrope profile follows a similar slope as the observed profile, but with $\mathrm{xMg}$ concentrations of 0.03 lower than observed. Modeled and observed $\mathrm{xCa}$ values are similar at the rim. Modeled xMn values are 0.06 higher than observed at the core, but match the observed at the rim. These observations suggest that additional intracrystalline 
diffusion not considered in this model influenced the garnet crystal.

Changes to the heating rates and dwell times have only little influence on the modeled profiles due to the peak temperature of less than $600{ }^{\circ} \mathrm{C}$. The addition of a $100 \mathrm{My}$ dwell period at temperatures between 595 and $600{ }^{\circ} \mathrm{C}$ along the identical P-T path has a small impact on the slope and peaks of the almandine and spessartine profiles (Figure 4.3.3). Peak xFe content is reduced by 0.02 but is still 0.025 higher than observed, and core compositions are not affected. Additional diffusional relaxation is required to best-fit the spessartine and almandine profiles, requiring a longer dwell period or higher peak temperatures. This conflict can be explained as a result of different scenarios such as the misidentification of the chemical core of garnet, the presence of kinetic barriers preventing the nucleation of staurolite and/or kyanite, the chemical alteration of the sample during the retrograde path or inconsistencies in the thermodynamic database.

If the geometric core of the largest garnet crystal in this sample does not correspond to its chemical center, the garnet profiles observed will contain lower spessartine and grossular, and higher almandine and pyrope core contents than predicted by the model. Assuming that the geometric core is not the chemical core, a compositional profile of the chemical core will result in a better fit for the almandine, spessartine and pyrope profiles. The modeling of garnet growth follows the assumption that garnet grows at an equal rate in all directions from its nucleation point (Gaidies et al., 2008), and therefore does not predict such possibility. 
Higher peak $\mathrm{T}$ can be achieved by considering the presence of kinetic barriers to nucleation of new mineral phases, which is not done with this thermodynamic database and modeling software. Reaction overstepping can require additional energy equivalent to $30-40{ }^{\circ} \mathrm{C}$ for nucleation of staurolite (Waters and Lovegrove, 2002), and up to $70{ }^{\circ} \mathrm{C}$ for nucleation of aluminosilicates (Pattison and Tinkham, 2009), therefore peak T achieved for the metamorphism of this sample may have reached higher $\mathrm{T}$ than the upper limit by $30-40{ }^{\circ} \mathrm{C}$ without overstepping the kinetic barriers for the formation of staurolite and kyanite. A resulting peak $\mathrm{T}$ of $630-640{ }^{\circ} \mathrm{C}$ increases the intracrystalline diffusion rate significantly enough to match the observed diffusional relaxation levels of the compositional profile.

Additionally, the presence of chemical alteration causing enrichment in staurolite or kyanite forming elements would stabilize the formation of these minerals over a larger P$\mathrm{T}$ field in the model. No alteration textures are observed in this sample. Assuming that alteration occurred during the retrograde path (e.g. through fluids involved in the hydration of the sample, which is responsible for the formation of retrograde chlorite), the prograde metamorphism would have occurred in a bulk chemistry that does not form staurolite or kyanite at $\mathrm{T}$ above $600{ }^{\circ} \mathrm{C}$ for $\mathrm{P}$ of $7 \mathrm{kbar}$, and therefore peak $\mathrm{T}$ could be higher than predicted. A chemical alteration scenario that increases the size of the predicted P-T field for staurolite-bearing assemblage is the removal of Fe from the bulk rock after peak metamorphism. The removal of Fe results in the shift of the garnet-in reaction up $\mathrm{T}$ and $\mathrm{P}$, and the removal of staurolite bearing assemblages (Figure 4.3.4). Additional changes in the bulk $\mathrm{Mn}, \mathrm{Mg}$ and Ca contents influences the garnet-bearing 
assemblage fields which can in turn affect other fields such as staurolite-bearing and kyanite-bearing assemblages.

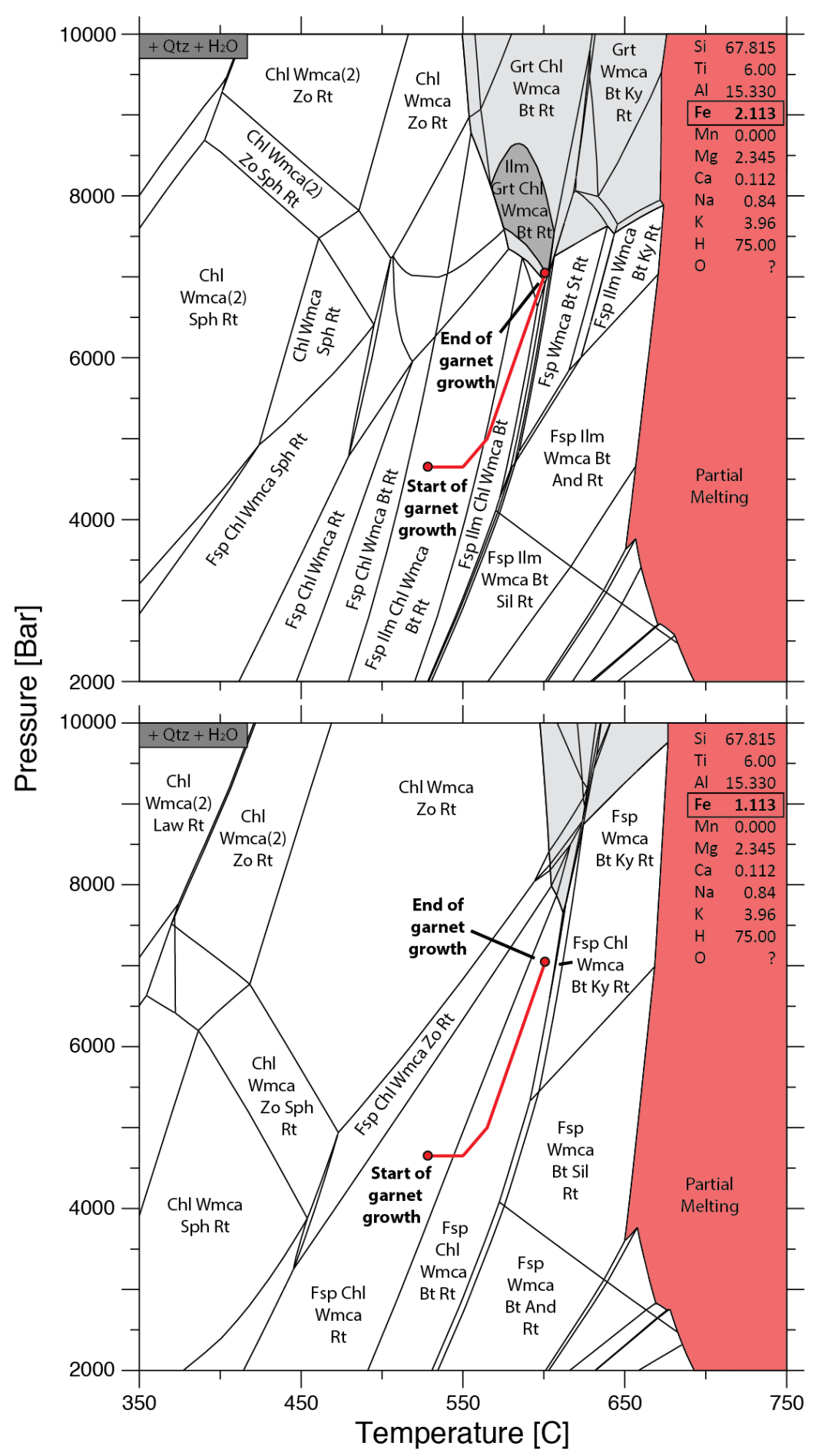

Figure 4.3.4 Comparison of different bulk $\mathrm{FeO}$ on phase equilibrium relations for sample 15RAYJR237B. The P-T path is displayed in both diagrams for reference. 
Finally, the uncertainties may be attributed to the thermodynamic database not appropriately predicting the composition of $\mathrm{Mn}, \mathrm{Fe}, \mathrm{Mg}$, and $\mathrm{Ca}$-bearing phases. For example, with the presence of Mn-bearing mineral phases other than garnet (e.g. chlorite, ilmenite, staurolite, etc.) that include higher contents of $\mathrm{Mn}$ than predicted, the garnet-in reaction moves to higher $\mathrm{P}-\mathrm{T}$ conditions. Concentrations of other end-member components of garnet are also strongly influenced by slight variations in the chemistry by unpredicted phases.

\section{RAYJR246A}

Garnet nucleation at P-T conditions of $4 \mathrm{kbar}$ and $510{ }^{\circ} \mathrm{C}$ is indicated by isopleth thermobarometry of the largest garnet crystal core (Figure 3.7.4). Iterative modeling of the evolving grossular profile during subsequent garnet growth and comparison with analyzed grossular profile yields a prograde heating and burial path that reaches the peak P-T conditions of $667^{\circ} \mathrm{C}$ and 6.8 kbar (Morneau et al., (in press); Table 4.3.3; Figure 4.3.5). The resulting modeled profile (Figure 4.3.6) closely matches the garnet compositional profiles analyzed for all end-member components. A different slope of the prograde P-T path or a change of the peak conditions results in a poor fit to analyzed compositional profiles and crystal size distribution of garnet. For example, an increase in peak $\mathrm{P}$ of 1 kbar results in decrease of almandine and increase of grossular content of the rim resulting in poor fit to analyzed composition. An increase of peak T by $100{ }^{\circ} \mathrm{C}$ results in increases in pyrope and almandine contents, and a decrease in grossular content of the rim. Peak P-T increases also result in an increase in the garnet crystal size and poor fit to the measured CSD. 
Table 4.3.3 Modeled P-T-t path of sample 15RAYJR246A.

\begin{tabular}{|c|c|c|c|}
\hline Temperature $\left({ }^{\circ} \mathbf{C}\right)$ & Pressure (bar) & Time (My) & Heating/Cooling Rate $\left({ }^{\circ} \mathbf{C} / \mathbf{M y )}\right.$ \\
\hline 507 & 3750 & 0 & 20 \\
\hline 518 & 4200 & 0.55 & 20 \\
\hline 533 & 4900 & 1.3 & 20 \\
\hline 550 & 5400 & 2.15 & 20 \\
\hline 580 & 5700 & 3.65 & 20 \\
\hline 650 & 6700 & 7.15 & 20 \\
\hline 667 & 6800 & 27.15 & 0.85 \\
\hline 530 & 3500 & 28.52 & 100 \\
\hline
\end{tabular}

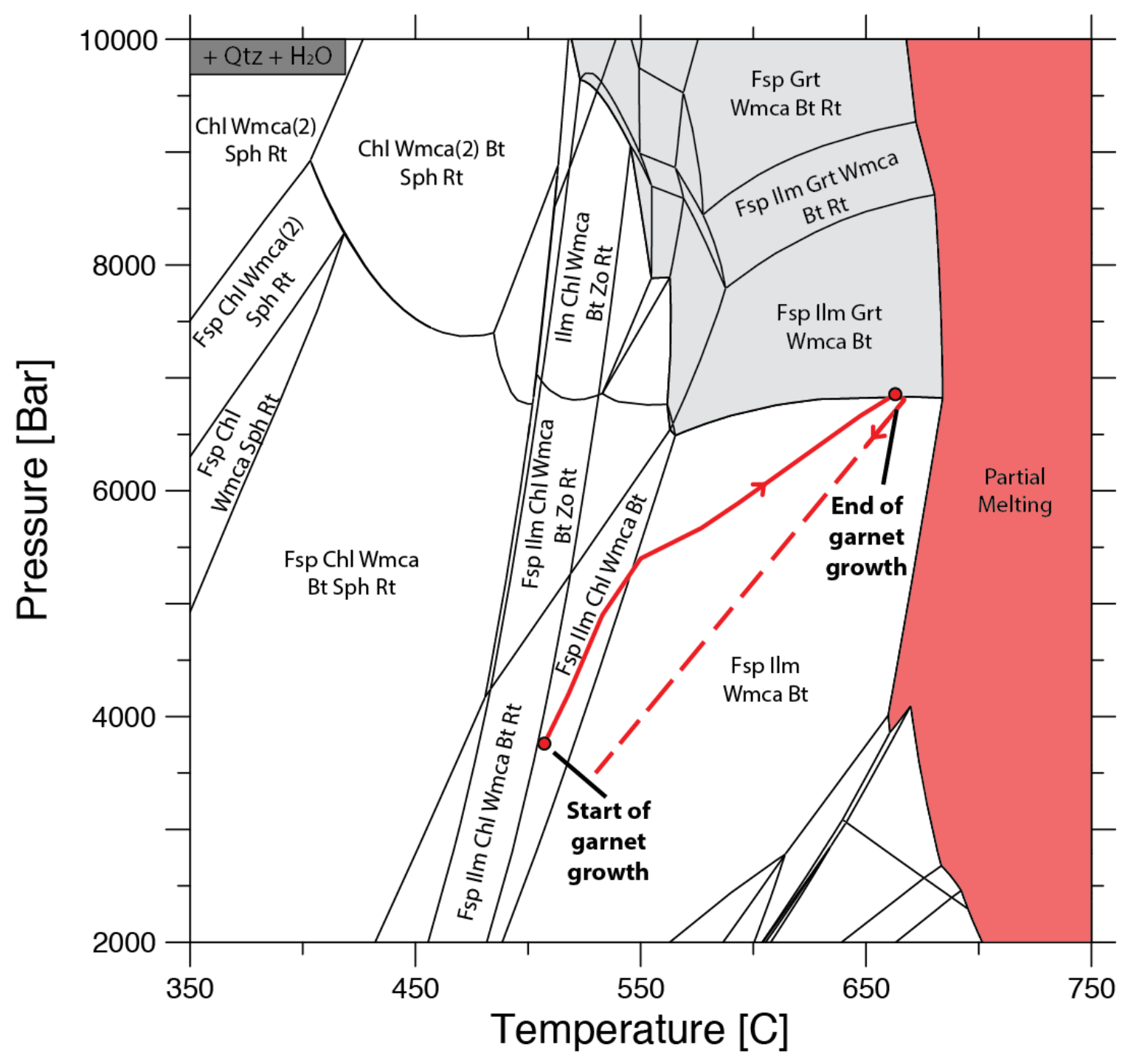

Figure 4.3.5 P-T-t path of sample 15RAYJR246A. Phase equilibrium diagram is modeled with the fractionated whole rock chemistry at the end of the garnet growth. Dashed lines represent an interpretation of the P-T path post-garnet growth. 


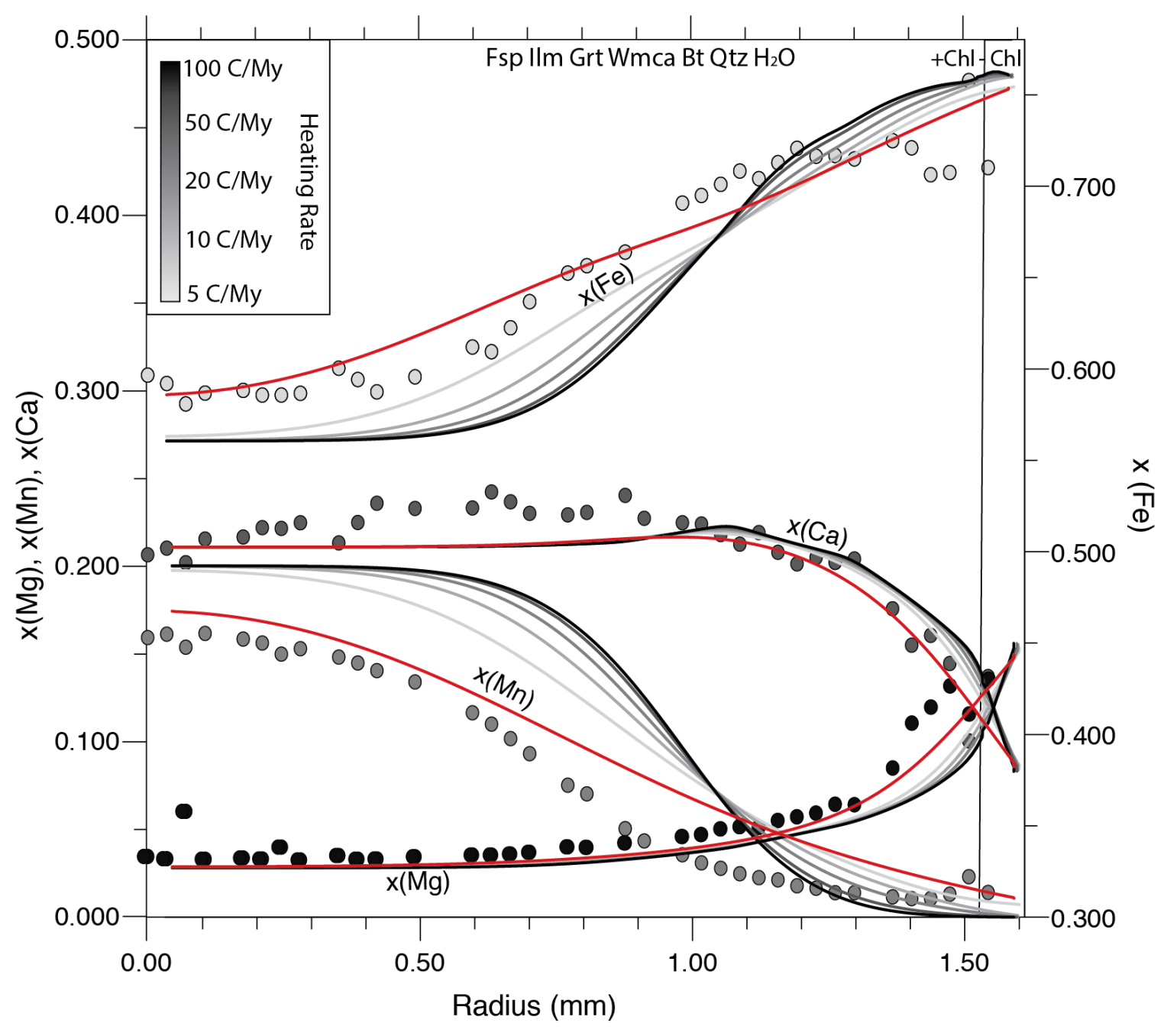

Figure 4.3.6 Modeled garnet compositional profiles for sample 15RAYJR246A. Profiles represent garnet growth along the same path with various heating rates. The red profile corresponds to the P-T-t path described in table 4.3.3, which contains a dwell time of $20 \mathrm{My}$ at temperatures between 650 and $667^{\circ} \mathrm{C}$.

Heating rate has a significant effect on the almandine and spessartine contents of garnet in the modeled temperature range because intracrystalline diffusion is efficient at these conditions. Rapid heating (e.g. $100^{\circ} \mathrm{C} / \mathrm{My}$ ) along the modeled P-T-t path produces a sharp increase in the almandine and decrease in the spessartine profiles between 0.75 and $1.25 \mathrm{~mm}$ from the core and results in a poor fit to the observed profiles (Figure 4.3.6). 
Slower heating rates $\left(50\right.$ to $5{ }^{\circ} \mathrm{C} / \mathrm{My}$ ) result in greater degree of intracrystalline diffusion in the almandine and spessartine profiles. However this is not significant enough to match the observed core compositions (Figure 4.3.6).

The fit of the modeled garnet profiles can be improved by incorporating a dwell time. The peak temperature strongly affects the dwell time required as diffusion is more efficient at higher temperature. The lower limit for peak $\mathrm{T}$ of $650{ }^{\circ} \mathrm{C}$ corresponds to the end of garnet growth, and the upper limit of $680^{\circ} \mathrm{C}$ corresponds to the highest $\mathrm{T}$ achievable without partial melting affecting the rock. With peak $\mathrm{T}$ of $650^{\circ} \mathrm{C}$, a dwell time of approximately $50 \mathrm{My}$ is necessary to match the observed garnet core composition, but with peak $\mathrm{T}$ of $680{ }^{\circ} \mathrm{C}$, a dwell time of only $12 \mathrm{My}$ is required. The best-fit profile was achieved using a heating rate of $20^{\circ} \mathrm{C} / \mathrm{My}$ until $650{ }^{\circ} \mathrm{C}$, followed by a heating rate of $0.85^{\circ} \mathrm{C} / \mathrm{My}$ from 650 to $667^{\circ} \mathrm{C}$. For a peak temperature of $667^{\circ} \mathrm{C}$, a dwell time of $20 \mathrm{My}$ is necessary to match the observed garnet profile. There may be no dwell time along the P-T-t path if the rock was exposed to a later heating event that reached temperatures above $600{ }^{\circ} \mathrm{C}$ and that was not accompanied by the repeated growth of garnet or formation of a new mineral phase.

The modeled profile very closely matches the observed garnet compositional profile. A small notable difference is observed in the rim of the almandine and pyrope profiles, at a distance between 1.35 and $1.6 \mathrm{~mm}$ from the core. In this area, the increase in slope of the pyrope profile is modeled $0.15 \mathrm{~mm}$ closer to the rim then what is observed. Similarly, the decrease in slope of the almandine profile is predicted 0.15 to $0.2 \mathrm{~mm}$ closer to the rim 
then observed. This difference can be explained if the chlorite-out reaction, which is predicted to occur at a distance of $1.52 \mathrm{~mm}$ from the core (Figure 4.3.6), occurs earlier than predicted along the path of garnet growth. Since chlorite becomes more depleted in Fe and more enriched in Mg as it is consumed by garnet (Inui and Toriumi, 2004), the changes in slopes that are caused by the termination of the chlorite-out reaction likely occurred earlier than predicted by the model, possibly reflecting an uncertainty in the thermodynamic database.

\subsubsection{Central Group}

\section{O0RAY098A}

Garnet end-member isopleths obtained through isopleth thermobarometry do not intersect at a precise P-T point due to the high amount of diffusional relaxation influencing the core composition (Figures 3.7.8 and 3.5.2). Nucleation of the largest garnet crystal is interpreted to have started at the intersection of the grossular isopleth with the garnet-in reaction. These conditions correspond to $550{ }^{\circ} \mathrm{C}$ and $4.5 \mathrm{kbar}$, and best constrain the start of the P-T-t path. Iterative modeling of the grossular profile results in a first stage of garnet growth that peaks at P-T conditions of $625^{\circ} \mathrm{C}$ and $5.45 \mathrm{kbar}$ (Table 4.3.4; Figure 4.3.7). Along this P-T-t path, garnet starts to grow in an assemblage containing Fsp + Ilm $+\mathrm{Chl}+\mathrm{Wmca}+\mathrm{Bt}+\mathrm{Qtz}+\mathrm{H}_{2} \mathrm{O}$. At approximately $1.55 \mathrm{~mm}$ radial growth of the largest garnet crystal, chlorite leaves the assemblage and staurolite enters. The resulting grossular and pyrope profiles best-fit the observed profiles (Figure 4.3.8). 
Table 4.3.4 Modeled P-T-t path of sample 00RAY098A.

\begin{tabular}{|c|c|c|c|}
\hline Temperature $\left({ }^{\circ} \mathbf{C}\right)$ & Pressure (bar) & Time (My) & Heating/Cooling Rate $\left({ }^{\circ} \mathbf{C} / \mathbf{M y}\right)$ \\
\hline 555 & 4500 & 0 & 20 \\
\hline 600 & 5450 & 2.25 & 20 \\
\hline 680 & 5450 & 6.25 & 20 \\
\hline 685 & 5450 & 81.25 & 0.04 \\
\hline 600 & 4000 & 85.5 & 0.13 \\
\hline 560 & 4000 & 87.5 & - \\
\hline 560 & 5700 & 89 & 20 \\
\hline 575 & 5900 & 89.75 & 20 \\
\hline 580 & 5950 & 90 & 20 \\
\hline 550 & 4750 & 91.5 & \\
\hline
\end{tabular}

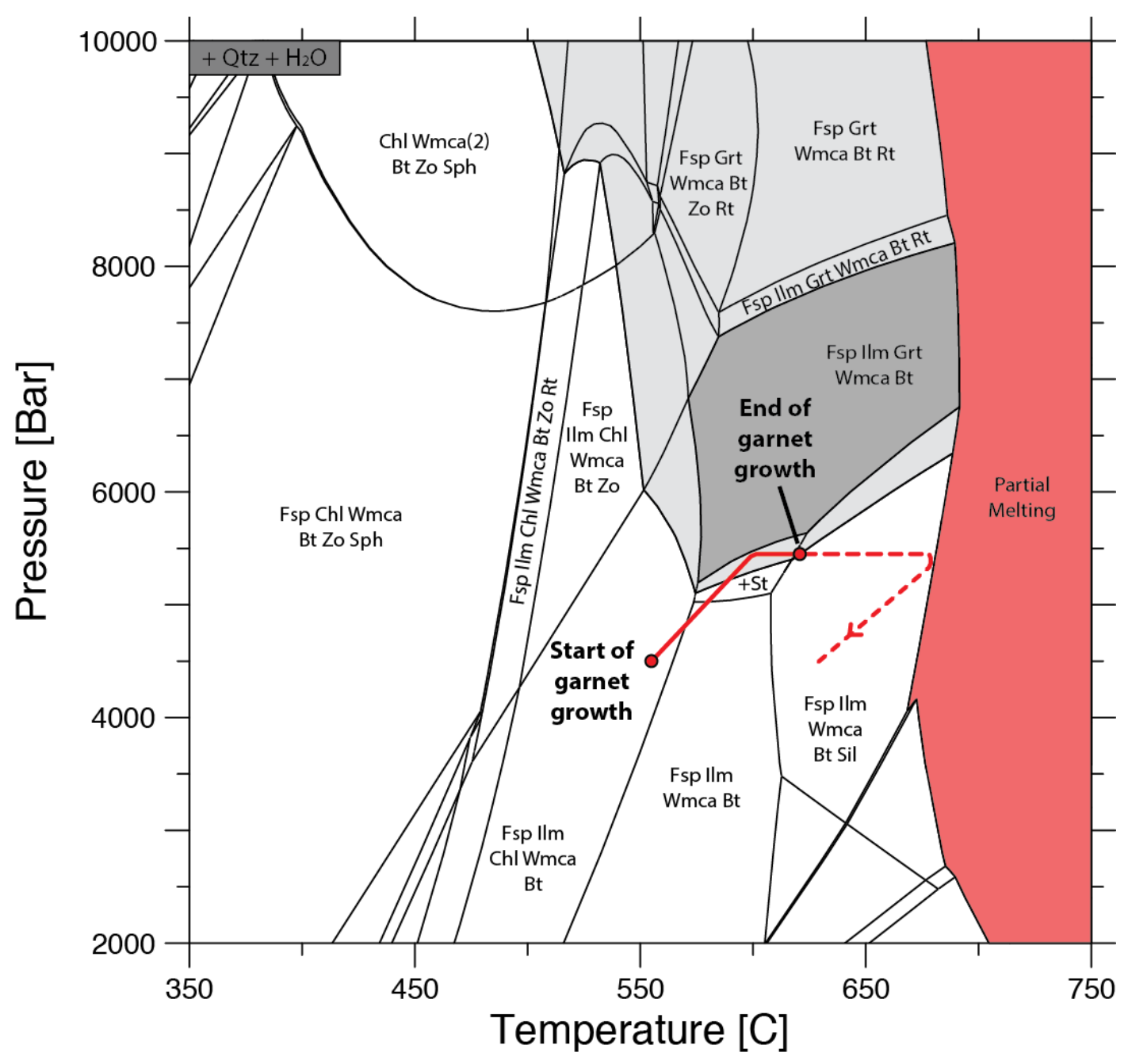

Figure 4.3.7 P-T path for first phase of garnet growth in sample 00RAY098A. Phase equilibrium diagram is modeled with the fractionated whole rock chemistry at the end of the garnet growth.

Dashed lines represent an interpretation of the P-T path post-garnet growth. 


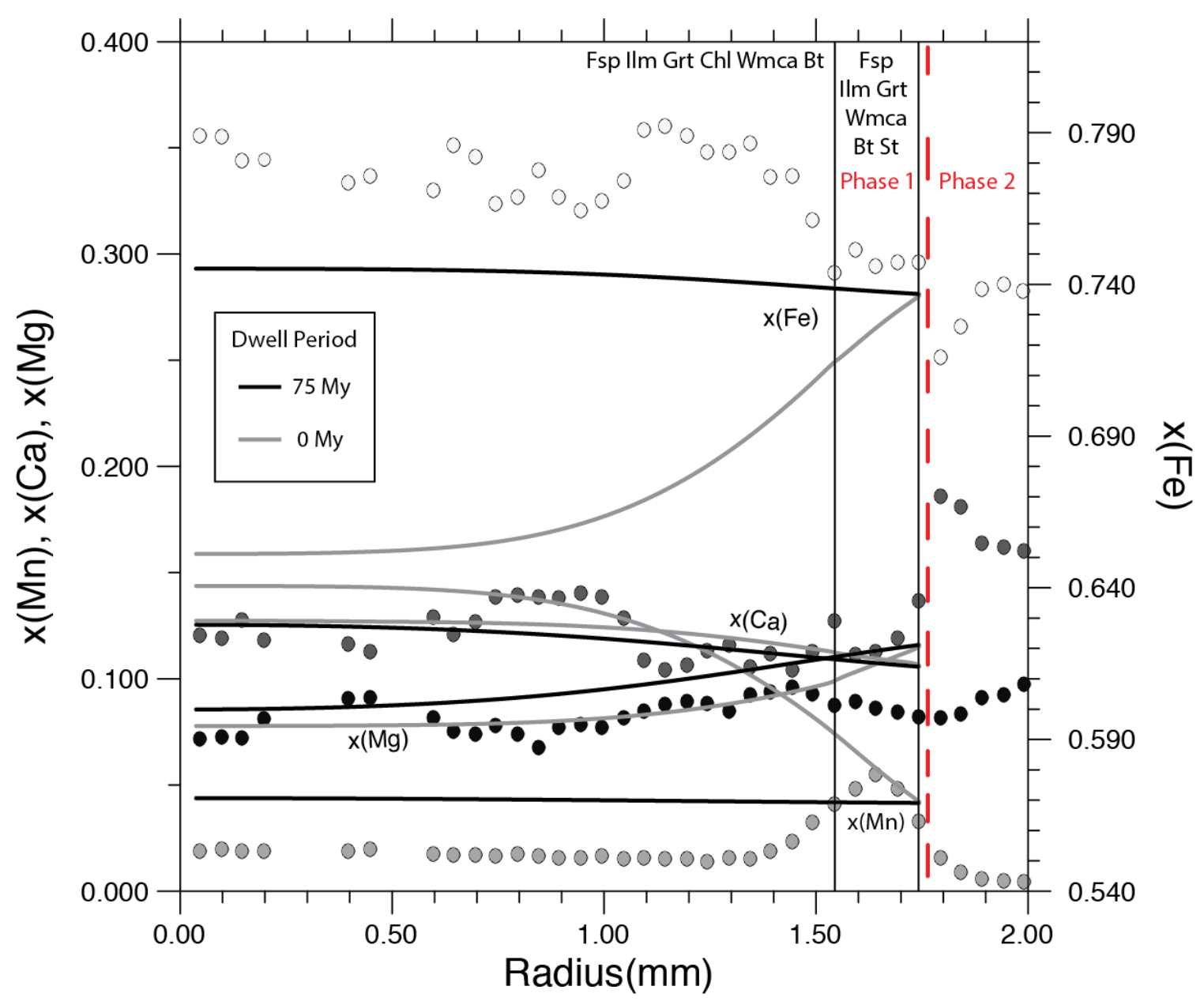

Figure 4.3.8 Modeled garnet compositional profiles for first phase of garnet growth in sample 00RAY098A. Profiles represent garnet growth along the same path with various dwell periods at peak T.

The almandine and spessartine profiles require significant intracrystalline diffusion to best-fit the observed contents, which can be obtained with the presence of a 60-75 My dwell time post-garnet growth at $\mathrm{T}$ between 625 and $685^{\circ} \mathrm{C}$ (Figure 4.3.8). Variations in heating rates have little influence on the modeled profiles, indicating that a dwell period is necessary to fit the observed diffusional relaxation. The higher temperatures suggested 
by the diffusion modeling could have occurred at the end of the first P-T-t loop, or as a separate heating event after this period of metamorphism. This dwell period results in an increase in core $\mathrm{xFe}$ content from 0.65 to 0.75 and a decrease in $\mathrm{xMn}$ content from approximately 0.145 to 0.045 . xFe values remain approximately 0.03 lower than observed and the xMn values are approximately 0.025 higher than observed. Increases in the dwell period have no additional impact on the profiles for the corresponding peak $\mathrm{T}$.

The spessartine peak in the observed compositional profile at the end of the first phase of growth cannot be replicated in the models. Previous studies have observed similar peaks (Kohn and Spear, 2000) and associated them with garnet resorption during the retrograde path, and are commonly supported by the presence of biotite around garnet. In order to reproduce the spessartine contents observed in the compositional profile of 00RAY098A, significant garnet resorption is required, but is not supported due to the absence of abundant biotite around garnet (Figure 3.2.3a). An alternative source for the large spessartine peak is the breakdown of a Mn-bearing phase that is not considered in the modeling. This unpredicted increase in spessartine content is notably accompanied by a decrease in pyrope contents, falling to values approximately 0.03 lower than modeled at the end of the first phase of growth (Figure 4.3.8). It is also accompanied by a small decrease in the observed almandine profile by approximately 0.02 . These changes are not predicted in the modeled profiles.

Isopleth thermobarometry using the fractionated whole rock chemistry after the first phase of garnet growth results in an intersection point of approximately $560{ }^{\circ} \mathrm{C}$ and 5.7 
kbar (Figure 4.3.9), corresponding to the start of the second garnet growth phase. Modeling of the grossular profile for the second phase of garnet growth results in a second P-T-t loop that reaches peak conditions of $580{ }^{\circ} \mathrm{C}$ and $5.9 \mathrm{kbar}$ (Table 4.3.4; Figure 4.3.10). Modeling along this P-T-t path predicts garnet end-member profiles that best-fit the observed profiles (Figure 4.3.11). The final assemblage along this path consists of Fsp $+\mathrm{Grt}+\mathrm{Wmca}+\mathrm{Bt}+\mathrm{Qtz}+\mathrm{H}_{2} \mathrm{O}$, which matches the observed mineral assemblage. Modeled xFe content is approximately 0.02 lower than observed, but the distribution follows a similar slope. Similarly, the xMn content is approximately 0.02 higher than observed with a similar slope for the distribution. The compositional profiles of the second phase are best represented by a $20^{\circ} \mathrm{C} / \mathrm{My}$ heating rate.

Growth of garnet in the second loop begins at P 1 kbar higher and similar T and ends at peak P $0.5 \mathrm{kbar}$ higher and $\mathrm{T} 50^{\circ} \mathrm{C}$ lower than the first loop. The contact between the two phases of garnet growth in the compositional profile is sharp, indicative of a transition that occurred either rapidly or at $\mathrm{T}<585^{\circ} \mathrm{C}$, resulting in little intracrystalline diffusion. 


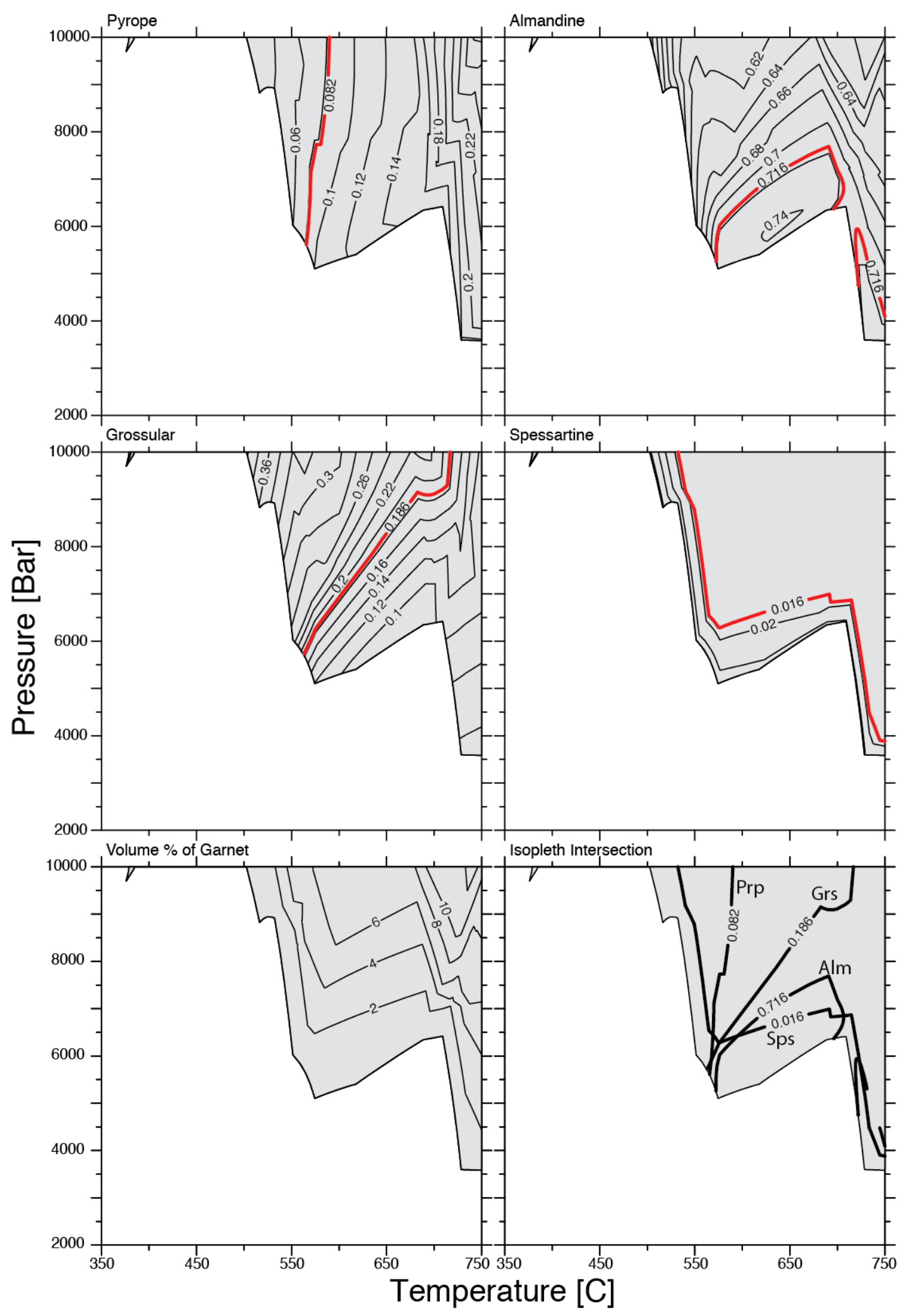

Figure 4.3.9 Garnet end-member isopleths for fractionated whole rock composition after first phase of garnet growth in sample 00RAY098A. 


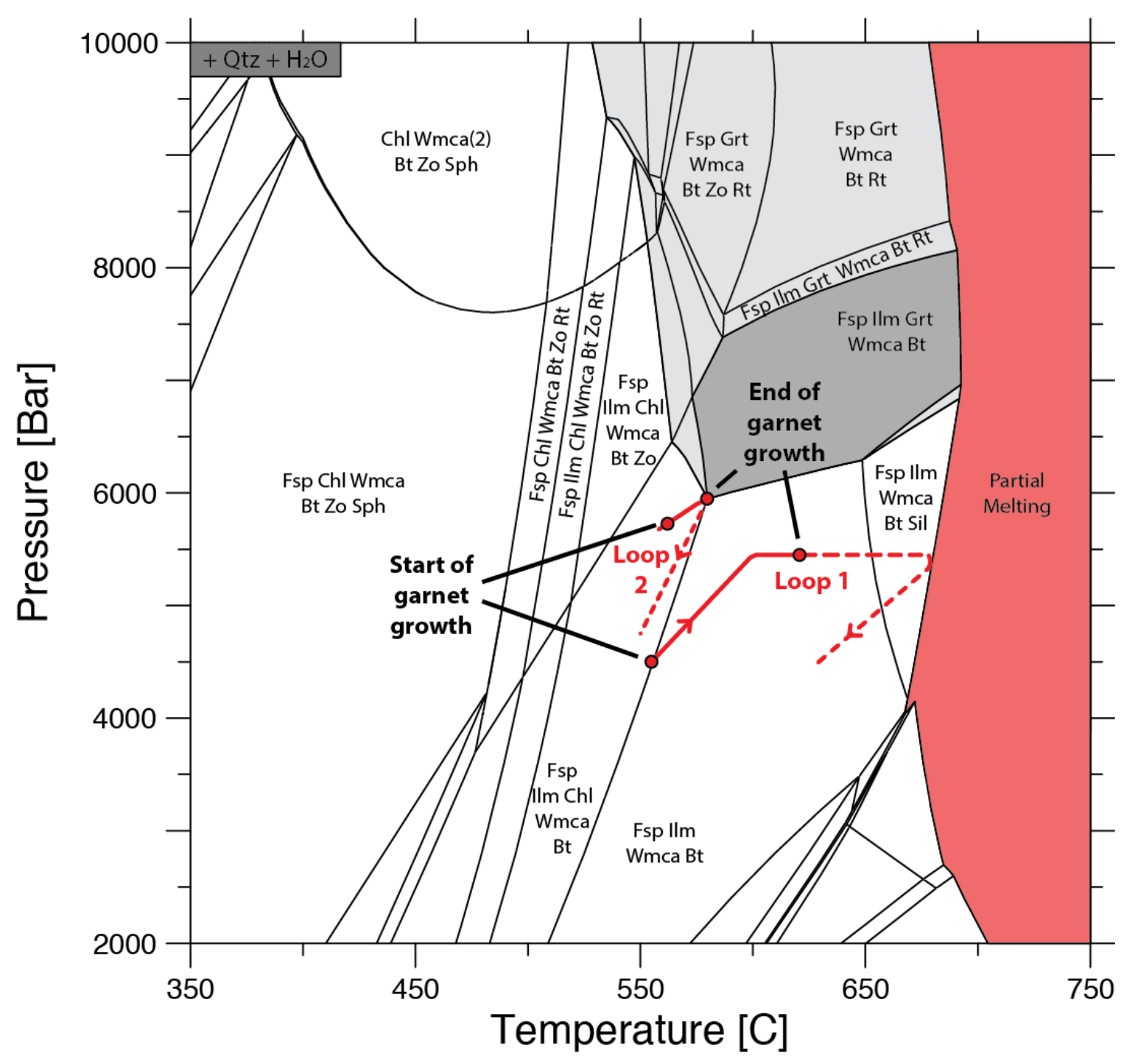

Figure 4.3.10 P-T path for both garnet growth episodes in sample 00RAY098A. Phase equilibrium diagram is modeled with the fractionated whole rock chemistry at the end of the second phase of garnet growth. Dashed lines represent an interpretation of the P-T path post-garnet growth. 


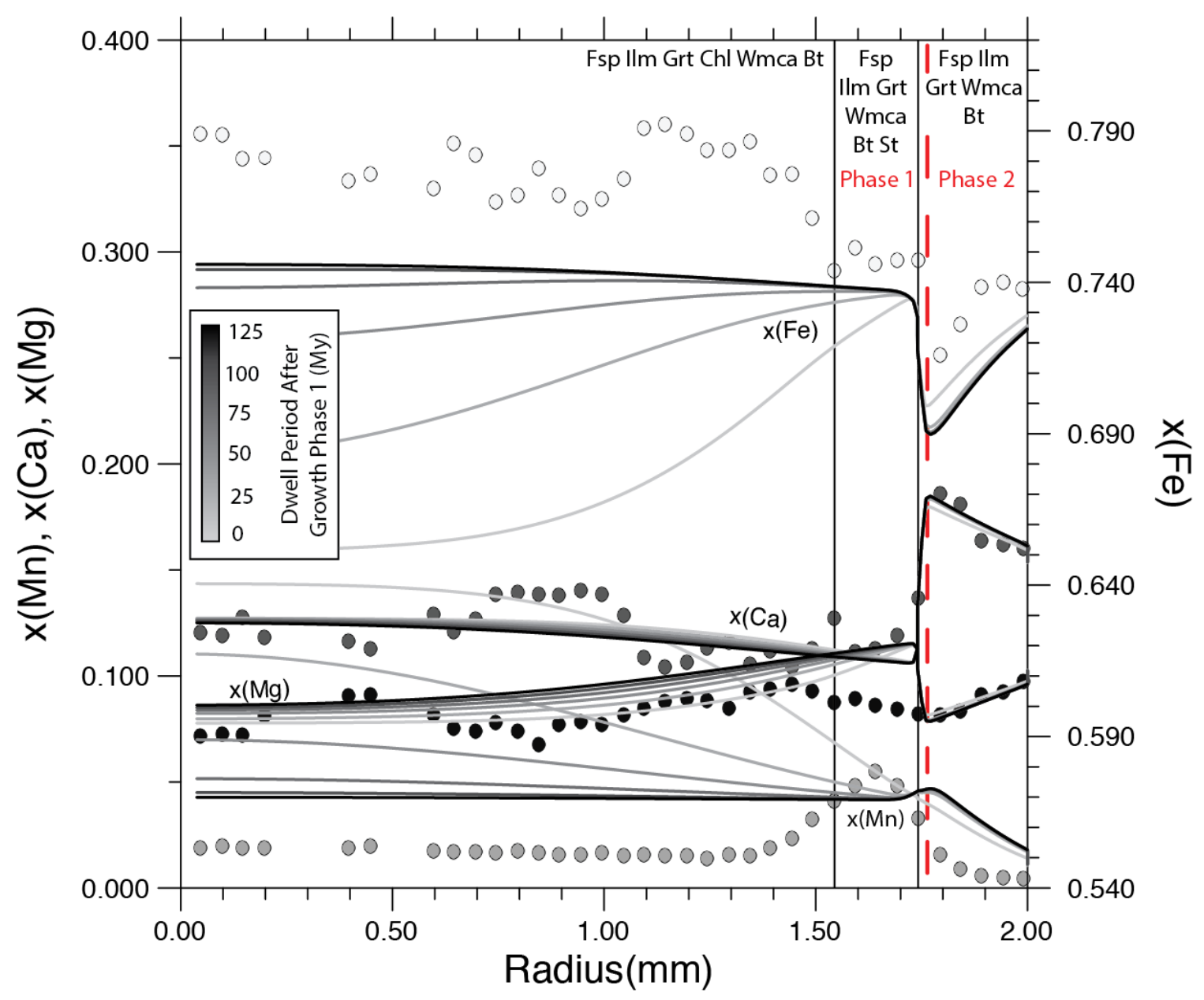

Figure 4.3.11 Modeled garnet compositional profiles for entire garnet growth in sample 00RAY098A. Profiles represent garnet growth along the same path with various dwell periods between the two phases of garnet growth. All dwell periods are at $\mathrm{T}$ of $680-685{ }^{\circ} \mathrm{C}$. Mineral assemblages also contain Qtz $+\mathrm{H}_{2} \mathrm{O}$.

\section{O0RAY231A}

Similar to sample 00RAY098A, garnet end-member isopleths do not intersect near the garnet-in line due to the high diffusional relaxation present in this sample (Figure 3.7.10) and the high whole rock $\mathrm{MnO}$ content (Table 3.3.1). The grossular isopleth crosses the garnet-in line at low P-T conditions of $466^{\circ} \mathrm{C}$ and $0.5 \mathrm{kbar}$. At these P-T conditions, 
current thermodynamic databases do not accurately represent garnet compositions. Iterative modeling attempts for the first phase of garnet growth following the best-fit grossular profile leads to a P-T path representative of a heating event with peak garnet growth P-T conditions of 0.5 kbar and $480{ }^{\circ} \mathrm{C}$ (Table 4.3.5; Figure 4.3.12).

Modeling results predict a flat grossular profile that fits the analyzed profile (Figure 4.3.13), but other profiles cannot be matched along this path. Higher P-T conditions are required to obtain observed values. Modeled pyrope content is 0.08 lower, and spessartine content is approximately 0.35 higher than observed. The model predicts almandine contents increasing from 0.39 at the core to 0.50 at the rim.

Table 4.3.5 Modeled P-T-t path of sample 00RAY231A.

\begin{tabular}{|c|c|c|c|}
\hline Temperature $\left({ }^{\circ} \mathbf{C}\right)$ & Pressure (bar) & Time (My) & Heating/Cooling Rate $\left({ }^{\circ} \mathbf{C} / \mathbf{M y}\right)$ \\
\hline 450 & 500 & 0 & 20 \\
\hline 500 & 500 & 2.5 & 20 \\
\hline
\end{tabular}




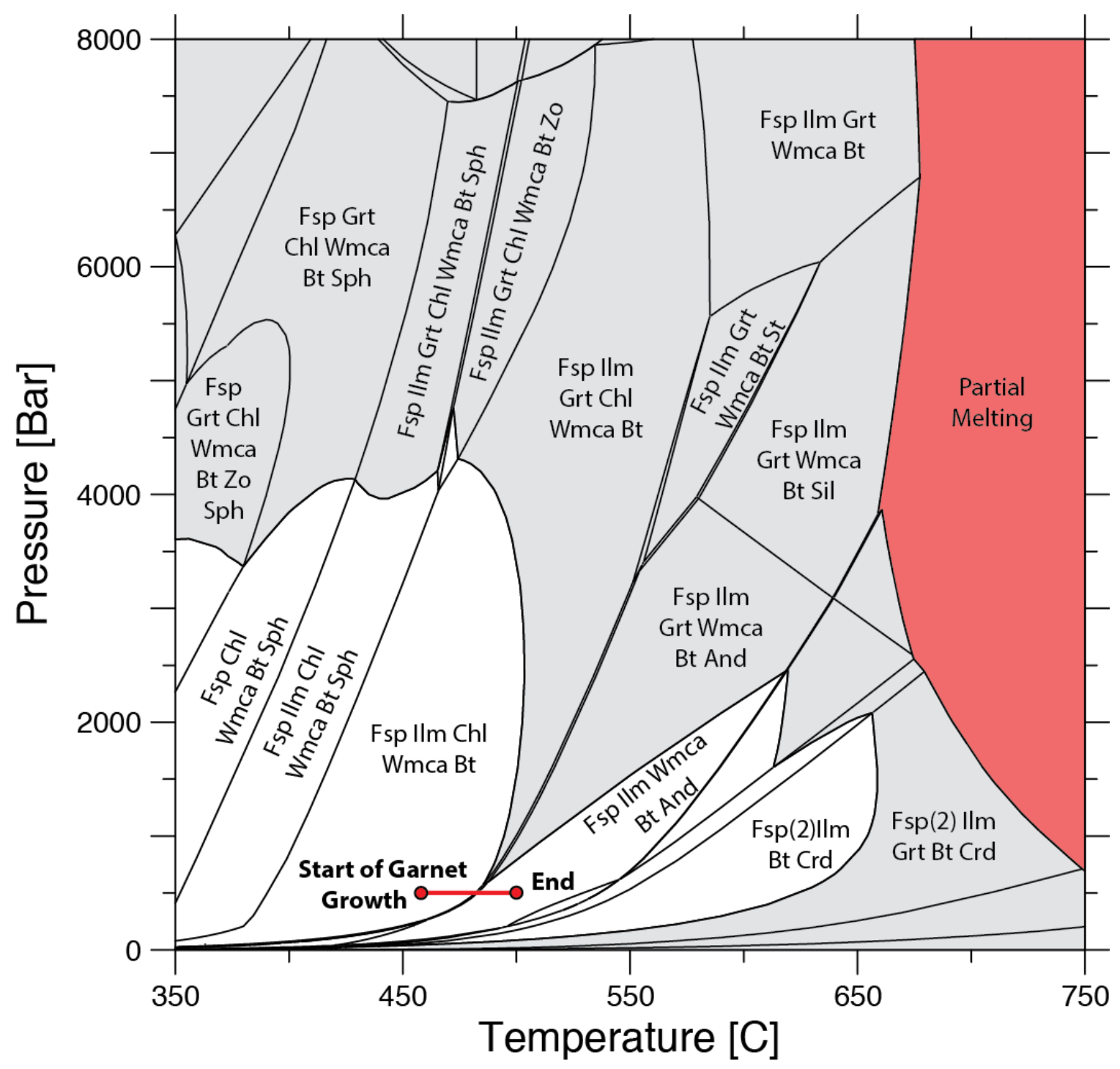

Figure 4.3.12 P-T-t path for the first garnet growth episode in sample 00RAY231A. Phase equilibrium diagram is modeled with the fractionated whole rock chemistry at the end of garnet growth. 


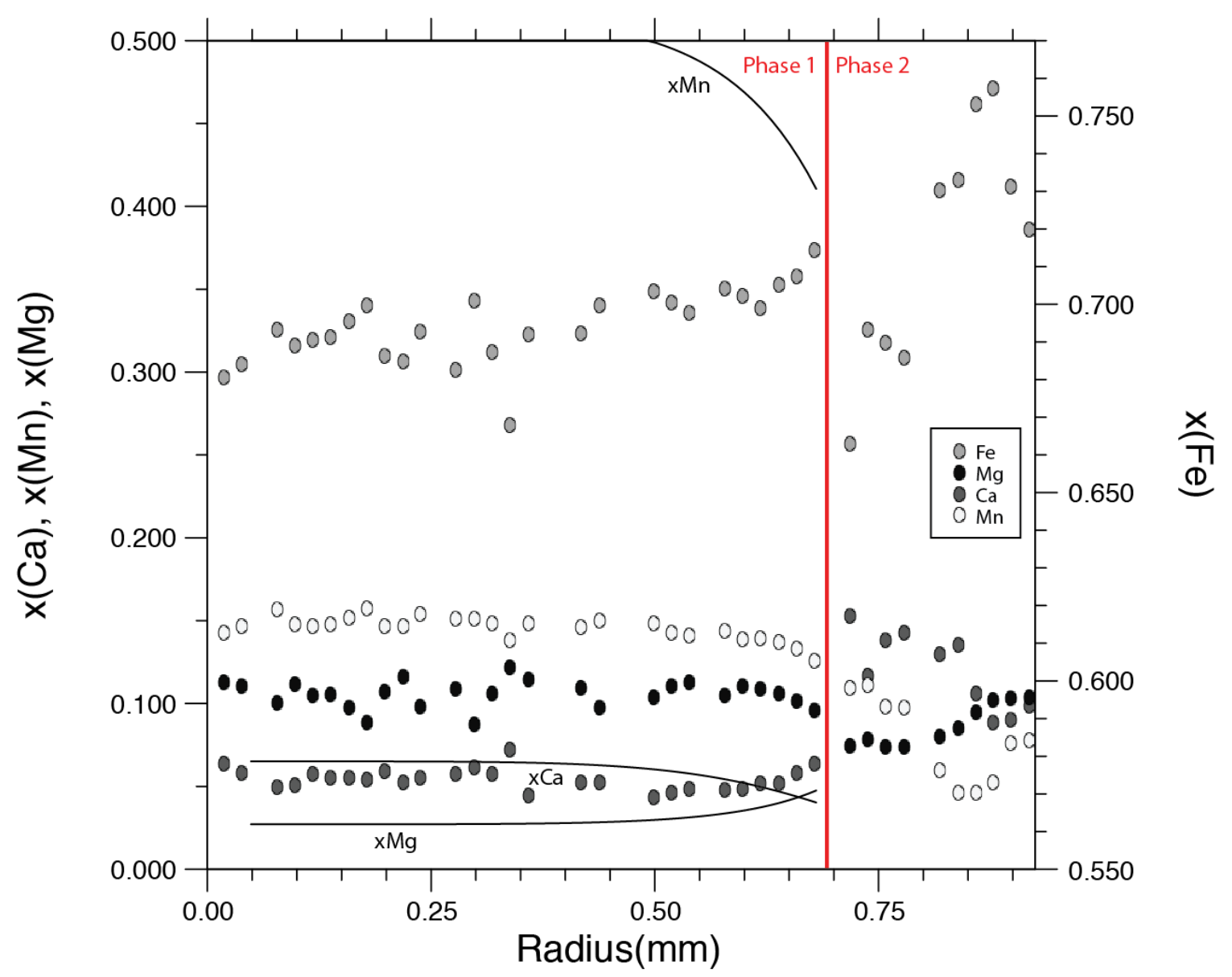

Figure 4.3.13 Modeled garnet compositional profile for the first phase of garnet growth in sample 00RAY231A.

Modeling of the heating event that causes garnet growth under different pressures has no significant impact on the pyrope, spessartine and almandine profiles. Results of the model are strongly influenced by the inaccurate predictions of garnet composition at low P-T conditions and are therefore not precisely representative of the event. Garnet volumes predicted by the model suggest that the P-T path of the first phase of metamorphism remained within the amphibolite facie, likely at low $\mathrm{P}$. Increases in peak $\mathrm{P}$ of this path results in a predicted volume of garnet larger than that observed in the sample. 
Further modeling of this sample was not attempted due to the presence of multiple inconsistencies and the difficulty of inferring the exact conditions of garnet growth. The fractionated bulk chemistry at the end of the first growth phase is not accurate and additional modeling would not be representative.

\subsubsection{Chemical Fractionation and Resulting Changes in Equilibrium Assemblages}

Growth of garnet, and consequent fractionation of the whole rock has a significant influence on the results of phase equilibrium modeling for the samples examined.

For sample 15RAYJR237B, noteworthy differences resulting from chemical fractionation associated with garnet growth include the ilmenite-in and rutile-out reactions being moved across significant temperature ranges (Figure 4.3.14). Rutile becomes stable for the majority of the P-T range of $350-750{ }^{\circ} \mathrm{C}$ and $2-10$ kbar after fractionation of garnet is considered. Additionally, staurolite and ilmenite are not predicted to form in the same assemblage. In sample 15RAYJR246A, key differences include the disappearance of the stability field of staurolite-bearing assemblages when chemical fractionation associated with garnet growth is considered (Figure 4.3.15), and the stabilization of rutile at $\mathrm{T}<480$ ${ }^{\circ} \mathrm{C}$. For sample 00RAY098A, significant differences are observed after each phase of garnet growth (Figure 4.3.16). After the first phase of growth the rutile-bearing assemblage field becomes stable at low $\mathrm{P}$ for $\mathrm{T}$ between 450 and $500{ }^{\circ} \mathrm{C}$, and the staurolite-bearing assemblage field becomes smaller and moves up P by approximately $1.5 \mathrm{kbar}$. After the second phase of garnet growth, staurolite becomes unstable across the P-T range displayed. 


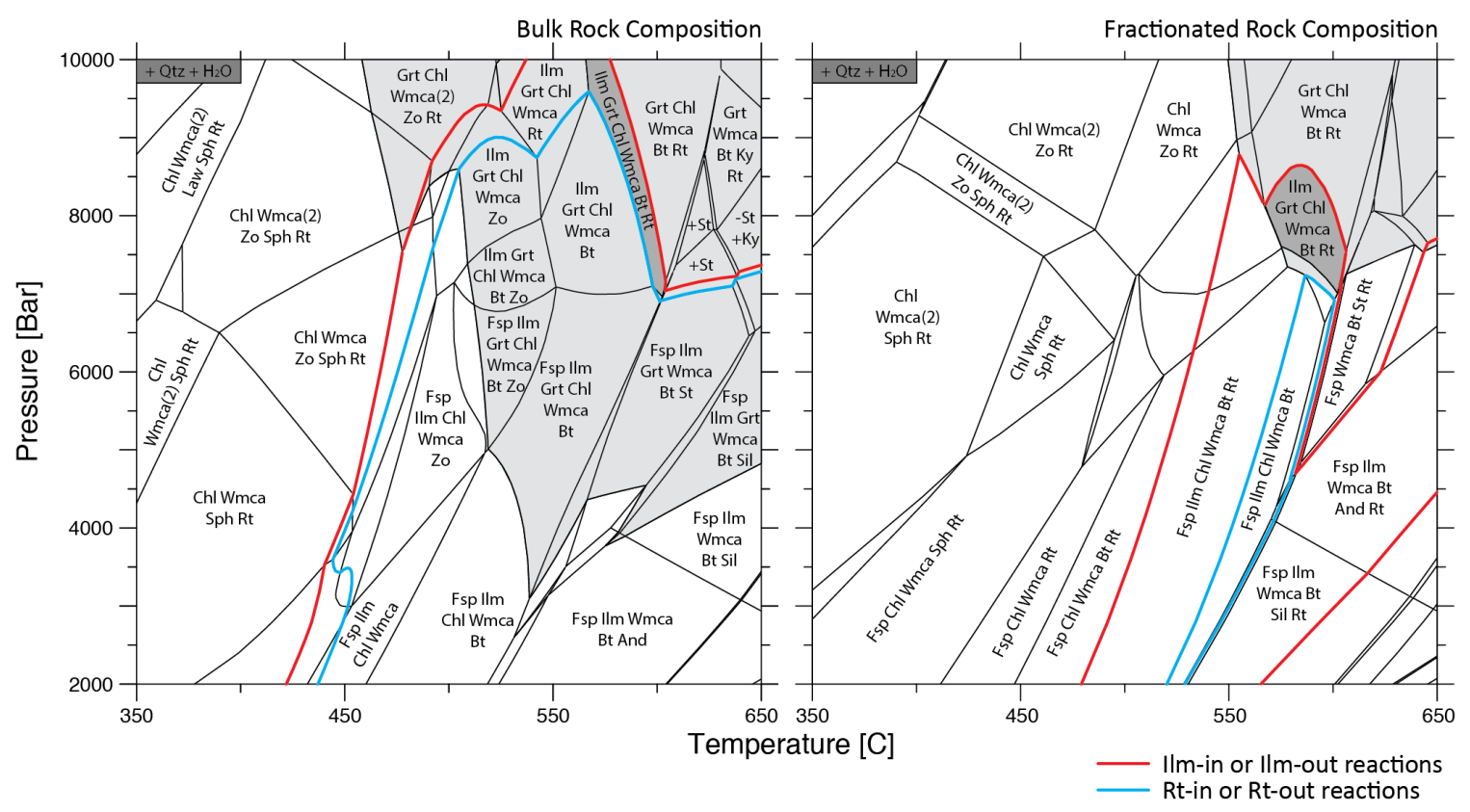

Figure 4.3.14 Phase equilibrium diagram comparison between whole rock composition and fractionated rock composition for sample 15RAYJR237B.

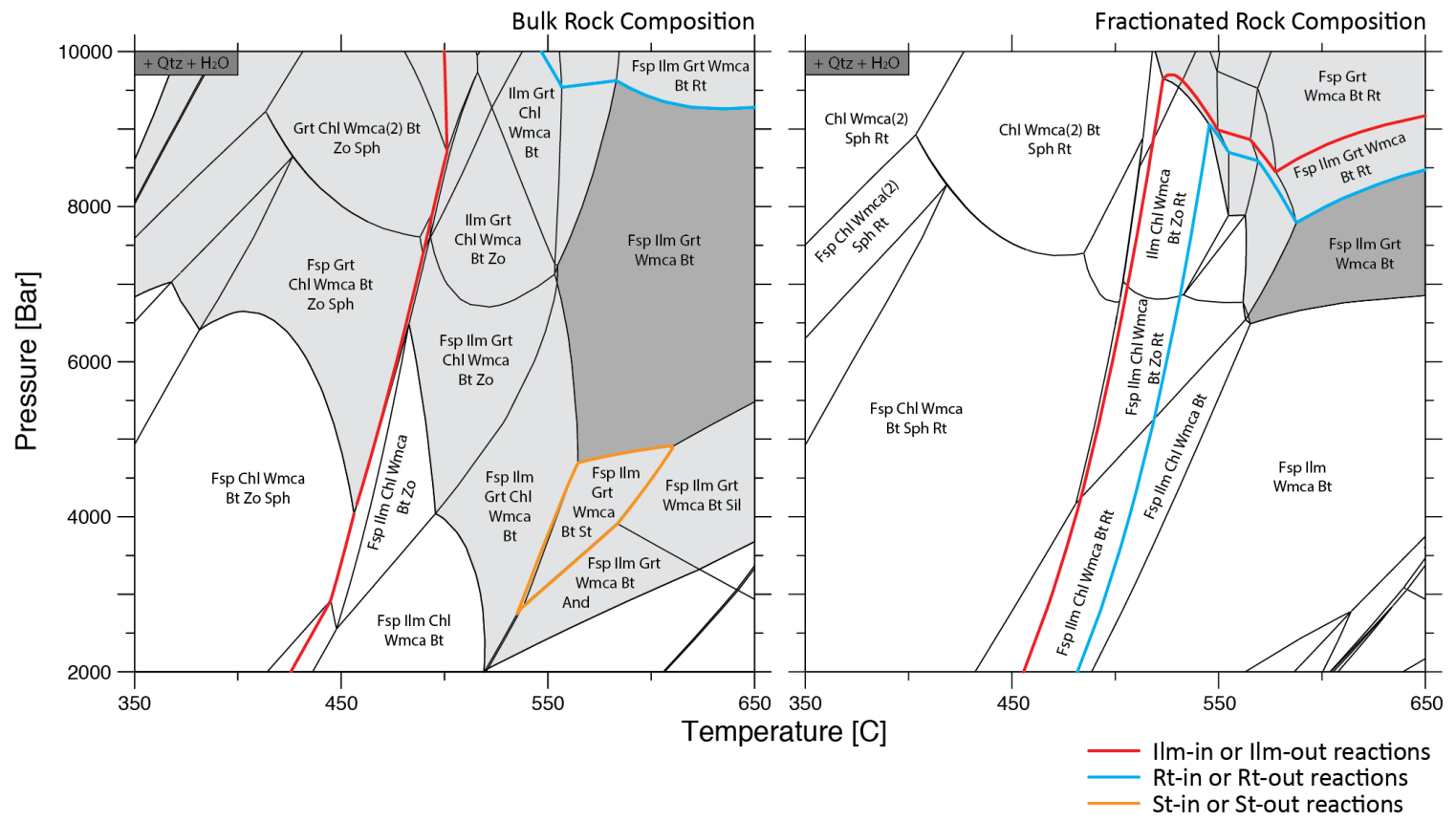

Figure 4.3.15 Phase equilibrium diagram comparison between whole rock composition and

fractionated rock composition for sample 15RAYJR246A. 


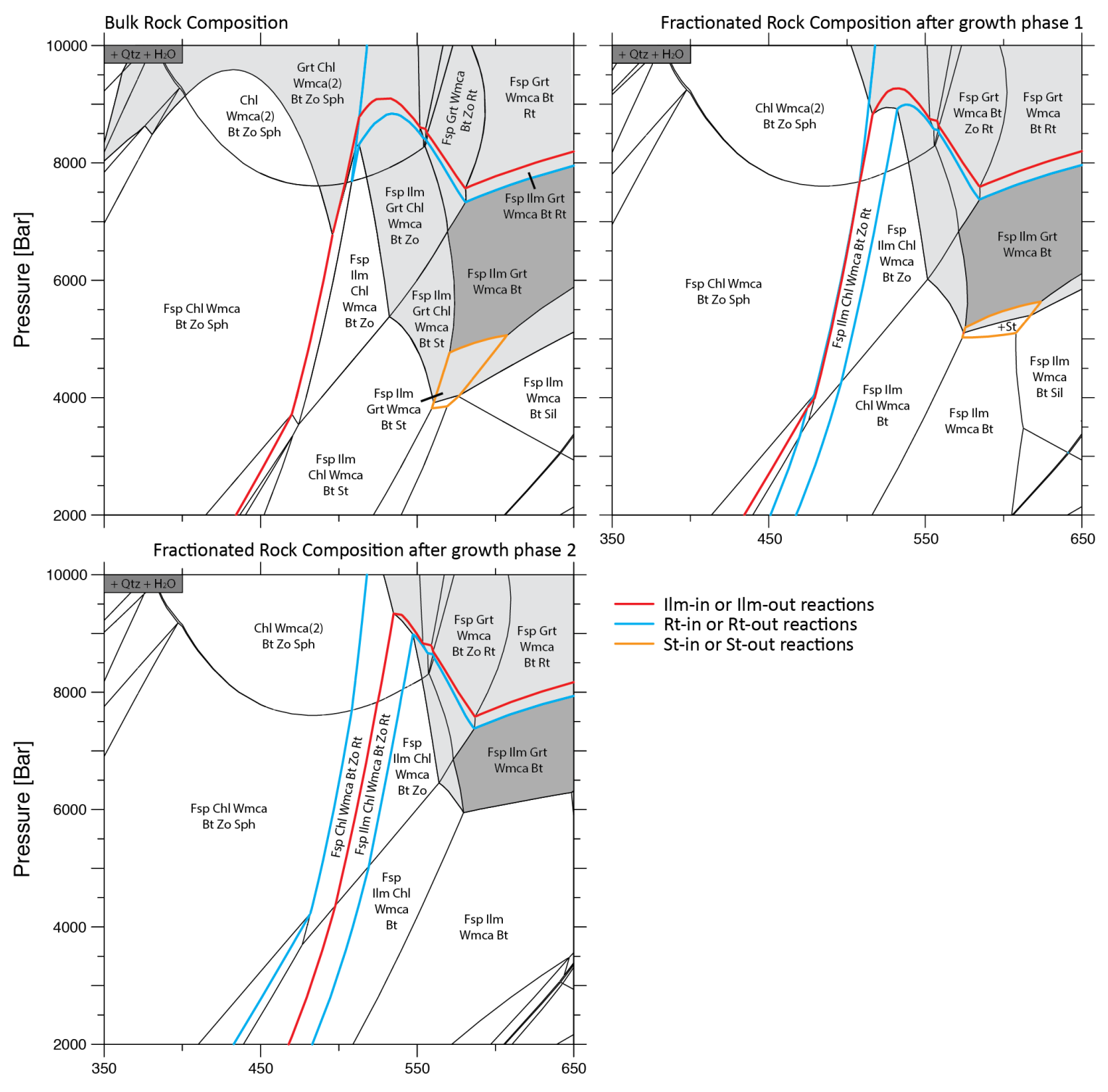

Figure 4.3.16 Phase equilibrium diagram comparison between whole rock composition and fractionated rock composition for sample 00RAY098A.

Phase equilibrium modeling based on the unfractionated whole-rock chemistry provides a general idea of the peak P-T conditions achieved by a garnet-bearing sample. However, the stability field of several mineral assemblages can change significantly as a result of garnet growth. Consideration of fractionation associated with garnet crystallization is 
necessary to obtain precise and accurate results for metamorphic studies involving compositionally zoned minerals.

\subsection{Tectonic Implications}

The Yukon-Tanana terrane has been exposed to diachronous Permian to Cretaceous metamorphism (Staples et al., 2016). This was due to collisional activities during this period yielding a range of various metamorphic ages. Previous dating methods have utilized monazite, zircon, titanite and Ar-Ar age-dating. The ages obtained from these two mineral phases may not correspond to the exact age of peak metamorphism in the scenario where a slow heating rate is influencing the system due to their growth occurring at an unknown point along the P-T-t path.

Resulting paths from garnet crystallization modeling for samples 15RAYJR246A, 15RAYJR237B, 00RAY098A, and 00RAY231A are compared in figure 4.4.1. The path for sample 00RAY231A is not representative as indicated by several inconsistencies, but is considered for general interpretation of Permo-Triassic garnet growth.

Evidence for a first metamorphic event during the Lower Mississippian, as interpreted by Berman et al. (2007), was not obtained in this study. According to this work, the first episode of metamorphism resulting in garnet growth identified herein occurred in sample 00RAY231A in Early Triassic (ca. $245 \mathrm{Ma}$ ) and is characterized by low P metamorphism reaching amphibolite facies conditions (Figure 4.4.2). Relatively high Mn content (e.g. $0.28 \mathrm{~mol} \% \mathrm{Mn}$ in sample 00RAY231 A relative to $0.09 \mathrm{~mol} \%$ in sample 15RAYJR246A) 
resulted in garnet growth at low P-T conditions. These conditions are not sufficient to grow garnet in other samples given their different whole rock compositions. The timing of this event corresponds to the Permo-Triassic event described by Berman et al. (2007), which is dated at $239 \mathrm{Ma}$. This event is described by Berman et al. (2007) to have started at low $\mathrm{P}$, but reached higher P-T conditions of $600{ }^{\circ} \mathrm{C}$ and $9 \mathrm{kbar}$ in the southern YTT and in Alaska, which is not observed in this study. The low P event inferred here is typical of Buchan-type or contact metamorphism, which are indicative of either an extensional tectonic setting or an oceanic arc setting with the presence of arc-magmatism.

In the Stewart River area, the voluminous Permian Sulphur Creek plutonic suite, part of the Klondike Assemblage, yields ca. 260 Ma ages (Beranek and Mortensen, 2011; Knight et al., 2013; Ruks et al., 2006). This magmatism is interpreted to result from a westdipping subduction zone of the Slide Mountain Ocean beneath the YTT. Sulphur Creek plutonic suite intrudes the Snowcap Assemblage and provides a high T source that is necessary for the Permian metamorphic event, but with a misfit in age of $15 \mathrm{My}$. This age difference may result from garnet growing over a long period of time (larger than reported analytical errors), therefore indicating an average time of crystal growth that is skewed towards the nucleation of garnet. Additional error can result from the influence of secondary Lu peaks in the rim of polyphase garnet, causing measured ages to be younger than the first phase of garnet growth.

The low $\mathrm{P}$ of this metamorphic event is also supported by regional constraints. The Buffalo-Pitts orogenic peridotite massif is located approximately $50 \mathrm{~km}$ to the southeast 
of the locality of sample 00RAY231A. It was exhumed into the Snowcap Assemblage at ca. 262-261 Ma (Canil et al., 2003; Johnston et al., 2007), indicating a significant Permian extensional episode. Emplacement of the orogenic peridotites into the upper crust can provide an alternative source of heat, but it also predates the age of metamorphism by ca. $16 \mathrm{My}$.

The absence of Permo-Triassic garnet crystallization in the majority of samples suggests that the Snowcap assemblage in the study area was not subjected to high P conditions during the Permo-Triassic. Peak P $>4$ kbar would have resulted in significant growth of this mineral phase, which is not observed in the rocks studied. Additionally, sample 00RAY231A contains relatively low volumes of Permo-Triassic garnet for its high whole rock $\mathrm{MnO}$ content. If the samples reached peak $\mathrm{P}>4 \mathrm{kbar}$, as previously suggested (Berman et al., 2007), garnet volumes would be significantly higher and Jurassic metamorphism would not result in additional garnet growth. In depth analysis of the Permo-Triassic metamorphic event in this study area is difficult due to the overprinting Jurassic metamorphic event, which is proposed here to have reached higher P-T conditions. 


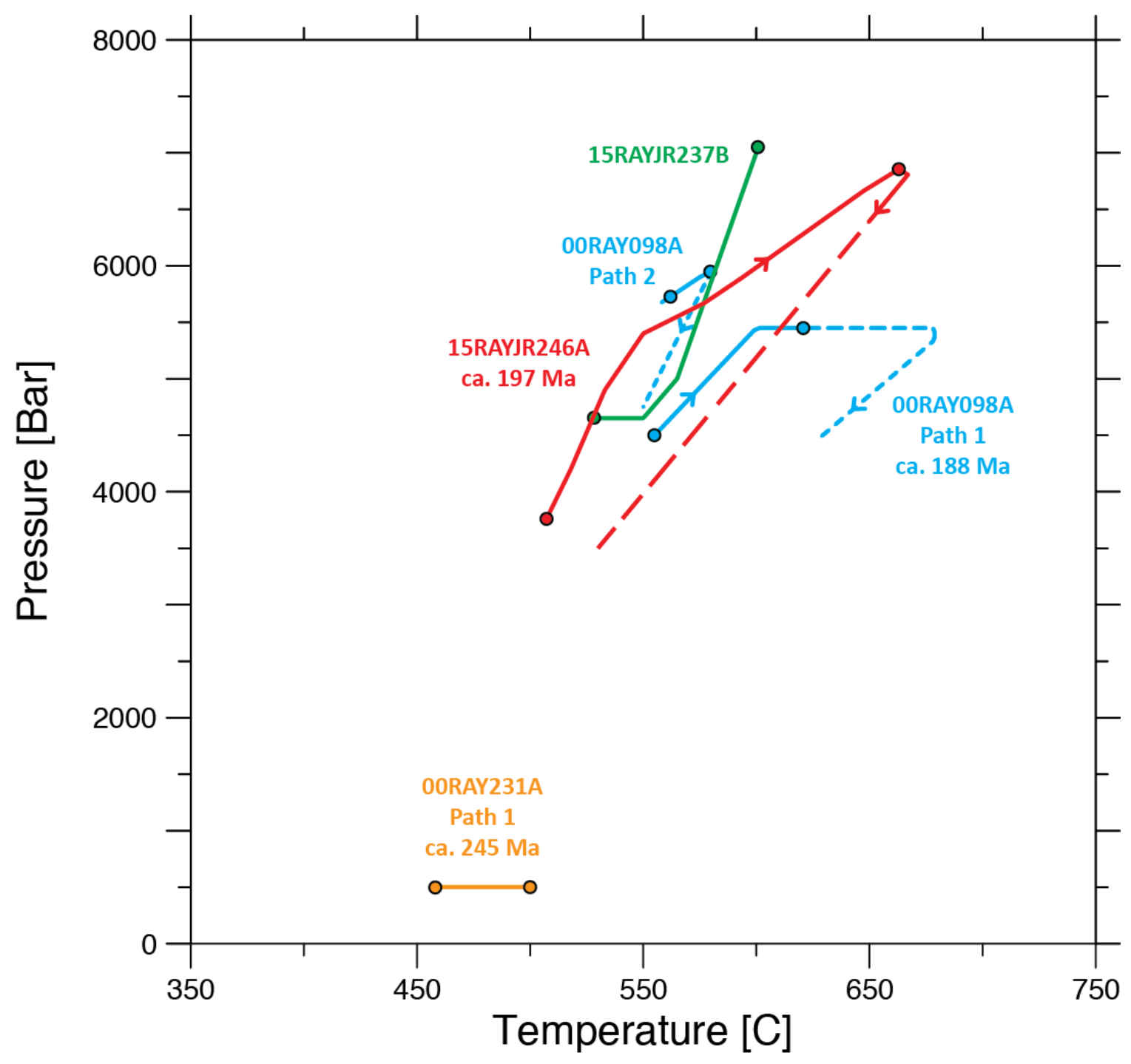

Figure 4.4.1 Comparison of P-T-t paths for samples 15RAYJR237B, 15RAYJR246A, O0RAY098A and 00RAY231A with ages of garnet growth. 


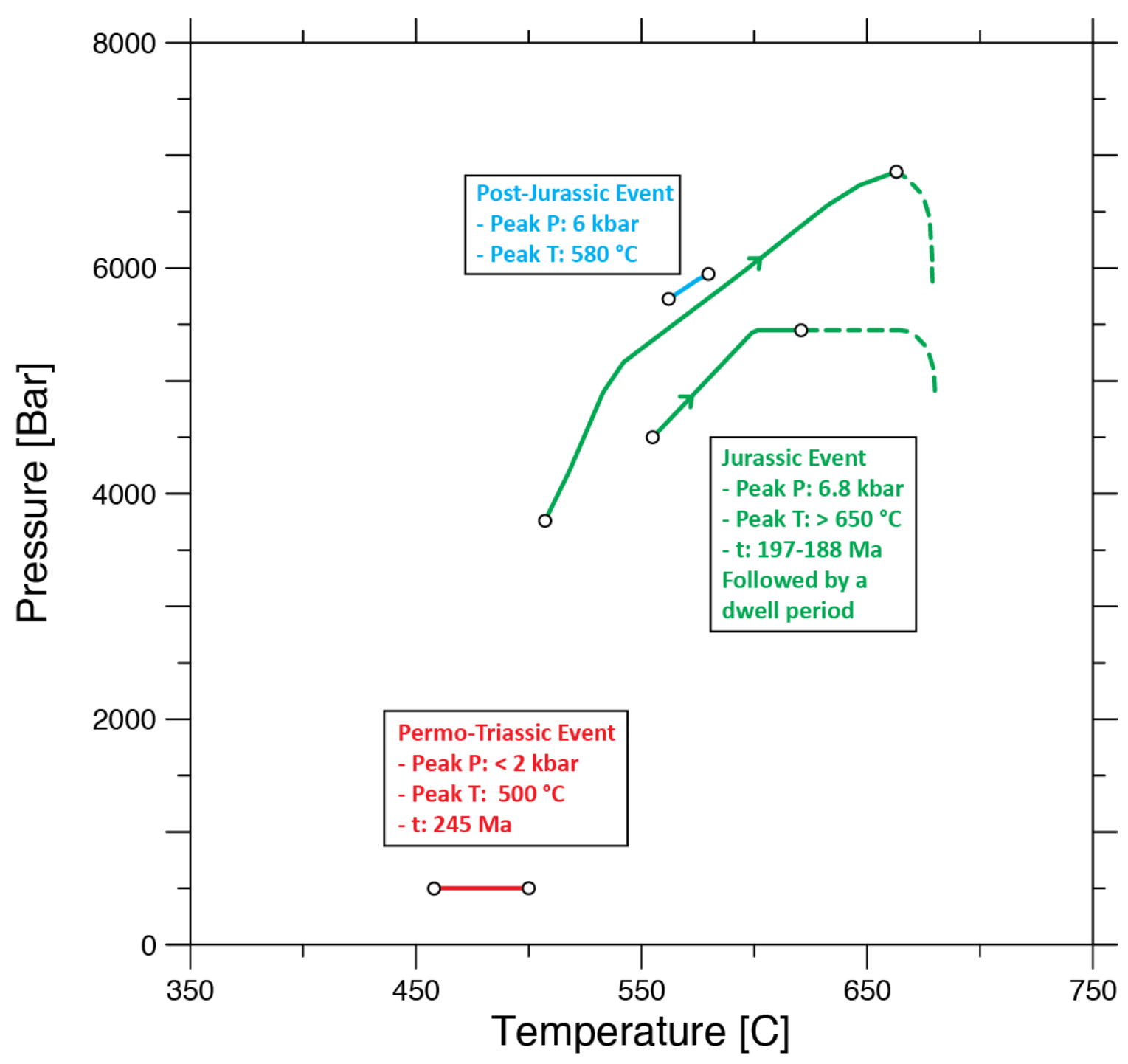

Figure 4.4.2 Summary of conclusive metamorphic events observed in the Stewart River area.

The Permo-Triassic metamorphic event is followed by the formation of a $\mathrm{S}_{\mathrm{M}-2}$ foliation and $\mathrm{S}_{\mathrm{M}-1}$ crenulation cleavage. These deformation features are not observed in Permian garnet cores of sample 00RAY231A, but forms inclusion trail patterns in garnet crystals that grew after this event. 
The second episode of metamorphism occurring in the Jurassic (ca. 197-188 Ma) resulted in garnet growth in all samples of this study. The P-T paths that characterize the observed garnet growth in samples 00RAY098A and 15RAYJR246A have a similar trajectory, but reach different peak P-T conditions (Figure 4.4.1). Sample 00RAY098A did not reach as high P-T conditions, peaking at $625^{\circ} \mathrm{C}$ and $5.5 \mathrm{kbar}$, while sample 15RAYJR246A peaked at $650{ }^{\circ} \mathrm{C}$ and $7 \mathrm{kbar}$. These results are similar to Jurassic (ca. 195-187 Ma) peak P-T conditions of $595^{\circ} \mathrm{C}$ and 7.8 kbar described by Berman et al. (2007). Garnet crystallization modeling results presented herein for the Jurassic phase of garnet growth suggest an increase in peak $\mathrm{T}$ of approximately 55 to $90{ }^{\circ} \mathrm{C}$ relative to that inferred by Berman et al. (2007), necessary to model the diffusional relaxation levels observed in the garnet compositional zoning. Peak P falls within thermodynamic error. This event corresponds to a Barrovian-type metamorphic event, indicating that it occurred within a collisional tectonic environment. This is consistent with previous associations of Jurassic metamorphism with the accretion of YTT onto Laurentia (Berman et al., 2007; Nelson et al., 2013), and closure of the Slide Mountain Ocean.

This period of garnet growth is followed by a high temperature dwell period that results in the observed intracrystalline diffusion in garnet. This dwell period could either occur along the P-T-t path, post garnet growth, or as a separate event, as long as the mineral assemblage is not changed. The peak T or duration of the dwell period is not consistent across all of the Stewart River area. Garnet crystals in samples from the central area show higher levels of relaxation than samples from the NW area, indicating either a higher $\mathrm{T}$ or a slower rate of T-change. If sample 15RAYJR246A (NW) experienced a peak $\mathrm{T}$ of $\sim 650$ 
${ }^{\circ} \mathrm{C}$, and sample 00RAY098 (Central) experienced a peak T of $\sim 685^{\circ} \mathrm{C}$, then their dwell period is similar (50-70 My). However, if both samples would have experienced the same peak $\mathrm{T}$ (e.g. $670{ }^{\circ} \mathrm{C}$ ), then their dwell periods would be significantly different with $20 \mathrm{My}$ for sample 15RAYJR246A and 150 My for sample 00RAY098A. A difference in the duration or $\mathrm{T}$ of the dwell period between the two samples is therefore necessary to explain the observed diffusion in garnet.

${ }^{40} \mathrm{Ar} /{ }^{39} \mathrm{Ar}$ biotite and amphibole cooling ages for the Stewart River and McQuesten areas (located just east of the Stewart River area) range between 197-165 Ma (Joyce et al., 2015; Knight et al., 2013). Additional cooling ages of ca. $142 \mathrm{Ma}$ and $90 \mathrm{Ma}$ are also reported, but attributed to local heating events. Garnet in the NW part of the study area, dated at ca. 197-192 Ma, shows intracrystalline diffusional activity that compliments these cooling ages if the dwell period occurs at $\mathrm{T}>660^{\circ} \mathrm{C}$. However, garnet in the central part of the study area, dated at ca. $188 \mathrm{Ma}$, requires additional timing or heat to match observed cooling ages indicating that either $\mathrm{T}>685^{\circ} \mathrm{C}$ were achieved without partial melting of the rock, or that a local heating event influenced these samples for a longer period of time, similarly to what is observed in the McQuesten area (Knight et al., 2013).

A third post-Jurassic metamorphic event recorded by the second stage of garnet growth in sample 00RAY098A reaches peak P-T conditions of approximately $6 \mathrm{kbar}$ and $580{ }^{\circ} \mathrm{C}$, at a heating rate of $20^{\circ} \mathrm{C} / \mathrm{My}$. This event, recorded as garnet overgrowths, must occur after the intracrystalline diffusion in the first garnet generation has taken place. Garnet growth 
only records a small part of this P-T-t path, and does not indicate whether the samples remained buried or if they were exhumed between garnet growth events. $\mathrm{S}_{\mathrm{M}-2}$ foliation in garnet crystals is consistently oriented across both phases of garnet growth, indicating the absence of rotation and the lack of deformation between the Jurassic and post-Jurassic garnet growth. Peak P-T conditions achieved in this event do not yield additional garnet growth in samples 15RAYJR246A and 15RAYJR237B, indicating that this event may have a regional extent. This last recorded metamorphic event is followed by the formation of the $S_{M}$ rock schistosity. Previous research on metamorphism in this study area did not indicate post-Jurassic garnet growth.

Samples near the Scroggie Creek pluton may have experienced a different pre-Jurassic metamorphic history as they may be of a different tectonic unit that is not part of the Snowcap Assemblage. Berman et al. (2007) identified Jurassic metamorphism (ca. 190$185 \mathrm{Ma}$ ) with peak P-T conditions of $5.4 \mathrm{kbar}$ and $600{ }^{\circ} \mathrm{C}$ for this area, indicating that it was exposed to the same Jurassic metamorphism as the Snowcap Assemblage. The locality of these samples is within a NW-SE trending exposure of Mississippian intrusive rocks (Figure 4.1.1), whereas samples from the NW and Central groups are located SW of the belt and appear to be mostly intruded by Permian intrusive units. The Scroggie Creek group is intruded by the Mississippian Simpson Range plutonic suite, but these Mississippian plutons are not present in the NW-SE extension of the Snowcap hosting other samples. This suggests that these samples may have been separated at the time of the intrusion of the Mississippian Simpson Range, resulting in the possibility of both groups accumulating sediments from a different source. A difference in timing of 
deposition or a difference in timing of separation from Laurentia can explain a change in depositional environment from passive continental margin to active continental margin or oceanic island arc, but must occur prior to Mississippian arc magmatism.

Alternatively, alteration of the Snowcap Assemblage occurred during the Jurassic emplacement of Scroggie Creek pluton, but prior to metamorphism (Berman et al., 2007). According to element mobility (Pearce, 1996), this alteration resulted in the depletion of mobile $\mathrm{Si}$, causing other major immobile elements such as $\mathrm{Al}, \mathrm{Fe}$, and $\mathrm{Ti}$ to become enriched. Such alteration is often accompanied by presence of quartz veins, which is documented in the area. Additional samples from these sedimentary rocks are necessary to better understand this group, as it is difficult to differentiate primary vs. alteration composition on the basis of two samples. 


\section{Chapter: Conclusions}

Results of this study are highly dependent on garnet growth during metamorphism. Metamorphic events that have not resulted in crystallization of garnet cannot be described with the methodology used. Garnet crystallization modeling results in high precision P-Tt paths that characterize Jurassic and post-Jurassic metamorphism in the study area.

The study area contains abundant amphibolite grade exposures of the Snowcap Assemblage. These results confirm the polymetamorphism and polydeformation attributed to this area, with additional new observations. The first event described herein consists of the Permo-Triassic event that resulted from arc-magmatism caused by the start of the closure of the Slide Mountain Ocean. In the study area, the Snowcap reached amphibolite facies metamorphism, while remaining at low P. This event was followed by two episodes of deformation forming an $\mathrm{S}_{\mathrm{M}-2}$ foliation, and a $\mathrm{S}_{\mathrm{M}-1}$ crenulation cleavage. These episodes of deformation occurred between the Early-Triassic (post Permian garnet growth), but prior to the Jurassic, and are recorded as inclusion trails in Jurassic garnet crystals.

The second metamorphic event described occurred during the Jurassic (ca. 197-188 Ma) and corresponds to the accretion of the Yukon-Tanana terrane onto Laurentia. This event followed typical Barrovian metamorphism, reaching peak P-T conditions of $7 \mathrm{kbar}$ and $670{ }^{\circ} \mathrm{C}$ at a heating rate of $20^{\circ} \mathrm{C} / \mathrm{My}$. Higher $\mathrm{P}$ of $7.8 \mathrm{kbar}$ are proposed by previous studies in the area. The event is followed by a dwell period, at $\mathrm{T}>600^{\circ} \mathrm{C}$. We suggest the presence of a third post-Jurassic episode of metamorphism resulting in limited garnet 
growth. This event reached peak P-T conditions of $6 \mathrm{kbar}$ and $580{ }^{\circ} \mathrm{C}$, following a heating rate of $20{ }^{\circ} \mathrm{C} / \mathrm{My} . \mathrm{S}_{\mathrm{M}-2}$ foliation observed as inclusion trails in garnet is consistently oriented in both Jurassic and post-Jurassic garnet, indicating the absence of deformation between both metamorphic events. The Snowcap Assemblage in the study area likely remained buried between these two metamorphic events, and was exhumed at a later time. $\mathrm{S}_{\mathrm{M}}$ foliation formed after the last stage of garnet growth.

This thesis provides new high quality constraints on the tectono-metamorphic evolution of west-central Yukon, however, additional research is needed to provide a comprehensive tectonic framework. Further research is needed to constrain the Mississippian metamorphic event, to better understand the provenance of Scroggie Creek area samples, and to constrain the timing of post-Jurassic garnet growth. Mississippian metamorphism constrained by titanite in as single sample identified by Berman et al. (2007) was not observed in this study. This could be due to the lack of garnet growth prior to the Permo-Triassic metamorphic event documented herein or some other factors. Targeted research into the Mississippian event could identify the cause of metamorphism, and subsequently test current tectonic interpretations that involve either contact metamorphism or shortening and thickening of the YTT.

Further research on the provenance of the sedimentary rocks in the Scroggie Creek area could also improve the tectonic interpretation of the YTT. Alteration of the Snowcap Assemblage would not strongly influence current interpretations, but classification of 
these metamorphosed sediments as a different tectonic unit would require introduction of a new tectono-stratigraphic unit that is distinctly different from the Snowcap assemblage. Finally, the post-Jurassic metamorphic event described in this study is very poorly constrained at present. Detailed studies on this event and its age would provide much needed constraints on the duration and peak $\mathrm{T}$ estimates for the dwell period that occurred between the Jurassic and post-Jurassic events. Additionally, these ages could be used to obtain appropriate cooling rates if compared to cooling ages. Due to this event resulting in limited garnet growth, new techniques and samples may be required. 


\section{Appendices}

\section{Appendix A - Garnet core composition}

Garnet core composition in wt. \% measured with EMPA.

\begin{tabular}{|c|c|c|c|c|c|c|c|c|c|}
\hline & $\begin{array}{c}\text { 15RAY } \\
\text { JR237B }\end{array}$ & $\begin{array}{r}\text { 15RAY } \\
\text { JR246A }\end{array}$ & $\begin{array}{l}\text { 15RAY } \\
\text { JR241A }\end{array}$ & $\begin{array}{c}\text { 00RAY } \\
\text { 098A } \\
\text { Grt 1 }\end{array}$ & $\begin{array}{c}\text { 00RAY } \\
\text { 098A } \\
\text { Grt } 2 \\
\end{array}$ & $\begin{array}{c}\text { 00RAY } \\
\text { 231A }\end{array}$ & $\begin{array}{r}\text { 11RAY } \\
\text { JR070A }\end{array}$ & $\begin{array}{c}\text { 10RAY } \\
\text { JR049A } \\
\text { Grt 1 } \\
\end{array}$ & $\begin{array}{c}\text { 10RAY } \\
\text { JR049A } \\
\text { Grt } 2 \\
\end{array}$ \\
\hline $\begin{array}{l}\mathrm{SiO2} \\
\text { (wt.\%) }\end{array}$ & 37.17 & 37.16 & 37.48 & 37.29 & 36.86 & 36.62 & 36.85 & 36.98 & 37.48 \\
\hline $\mathbf{A l}_{2} \mathbf{O}_{3}$ & 21.09 & 20.94 & 20.53 & 20.44 & 20.68 & 20.44 & 20.66 & 21.16 & 21.06 \\
\hline $\mathrm{FeO}$ & 30.72 & 26.58 & 24.71 & 35.03 & 34.87 & 30.87 & 31.02 & 34.83 & 32.10 \\
\hline MnO & 1.94 & 7.04 & 8.58 & 0.85 & 0.87 & 6.29 & 3.75 & 2.40 & 2.15 \\
\hline Mg0 & 1.57 & 0.89 & 3.43 & 1.76 & 1.70 & 2.70 & 0.71 & 2.21 & 2.10 \\
\hline CaO & 7.46 & 7.20 & 5.67 & 4.23 & 4.45 & 2.24 & 7.12 & 3.30 & 5.54 \\
\hline $\mathrm{TiO}_{2}$ & 0.10 & 0.09 & 0.12 & 0.10 & 0.06 & 0.05 & 0.09 & 0.01 & 0.17 \\
\hline $\mathbf{Y}_{2} \mathbf{O}_{3}$ & 0.08 & 0.36 & 0.03 & 0.29 & 0.32 & 0.14 & 0.00 & 0.08 & 0.11 \\
\hline Total & 100.13 & 100.26 & 100.55 & 99.99 & 99.81 & 99.35 & 100.20 & 100.97 & 100.71 \\
\hline O & 12.00 & 12.00 & 12.00 & 12.00 & 12.00 & 12.00 & 12.00 & 12.00 & 12.00 \\
\hline $\mathbf{S i}$ & 2.98 & 3.00 & 2.97 & 3.03 & 2.99 & 2.98 & 2.98 & 2.96 & 2.99 \\
\hline Al & 1.99 & 1.99 & 1.92 & 1.95 & 1.98 & 1.96 & 1.97 & 2.00 & 1.98 \\
\hline Fe3+ & 0.03 & 0.00 & 0.12 & 0.00 & 0.02 & 0.07 & 0.07 & 0.08 & 0.01 \\
\hline $\mathrm{Fe} 2+$ & 2.03 & 1.79 & 1.52 & 2.38 & 2.35 & 2.03 & 2.02 & 2.25 & 2.13 \\
\hline Mn & 0.13 & 0.48 & 0.58 & 0.06 & 0.06 & 0.43 & 0.26 & 0.16 & 0.15 \\
\hline Mg & 0.19 & 0.11 & 0.41 & 0.21 & 0.21 & 0.33 & 0.09 & 0.26 & 0.25 \\
\hline Ca & 0.64 & 0.62 & 0.48 & 0.37 & 0.39 & 0.20 & 0.62 & 0.28 & 0.47 \\
\hline $\mathbf{T i}$ & 0.01 & 0.01 & 0.01 & 0.01 & 0.00 & 0.00 & 0.01 & 0.00 & 0.01 \\
\hline $\mathrm{xFe}$ & 0.68 & 0.60 & 0.51 & 0.79 & 0.78 & 0.68 & 0.42 & 0.76 & 0.71 \\
\hline xMn & 0.04 & 0.16 & 0.19 & 0.02 & 0.02 & 0.15 & 0.09 & 0.06 & 0.05 \\
\hline xMg & 0.06 & 0.04 & 0.14 & 0.07 & 0.07 & 0.11 & 0.29 & 0.09 & 0.08 \\
\hline xCa & 0.22 & 0.21 & 0.16 & 0.12 & 0.13 & 0.07 & 0.21 & 0.10 & 0.16 \\
\hline
\end{tabular}


Appendix B - EMPA garnet transects images

\section{RAYJR237B}

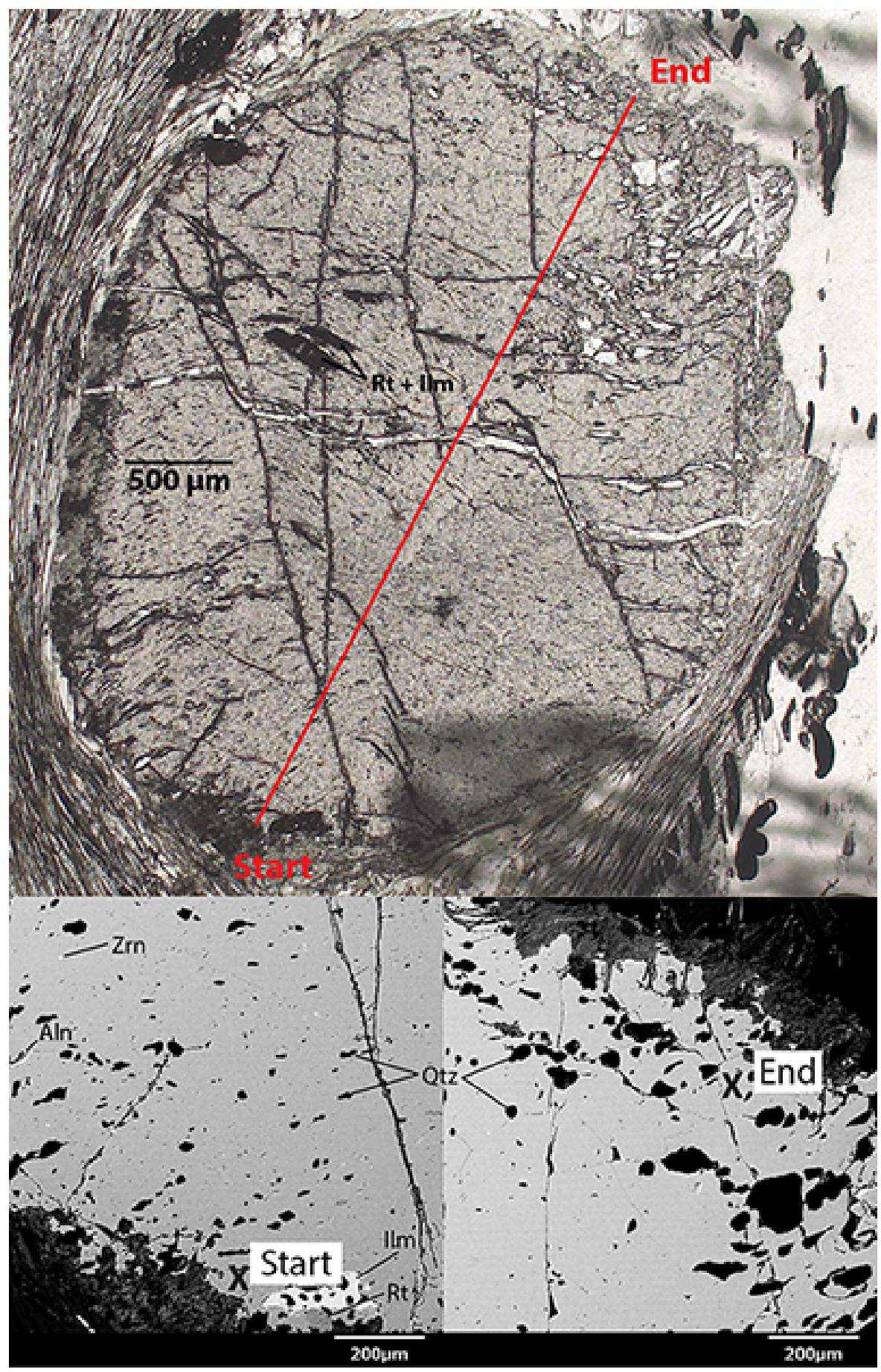


15RAYJR246A

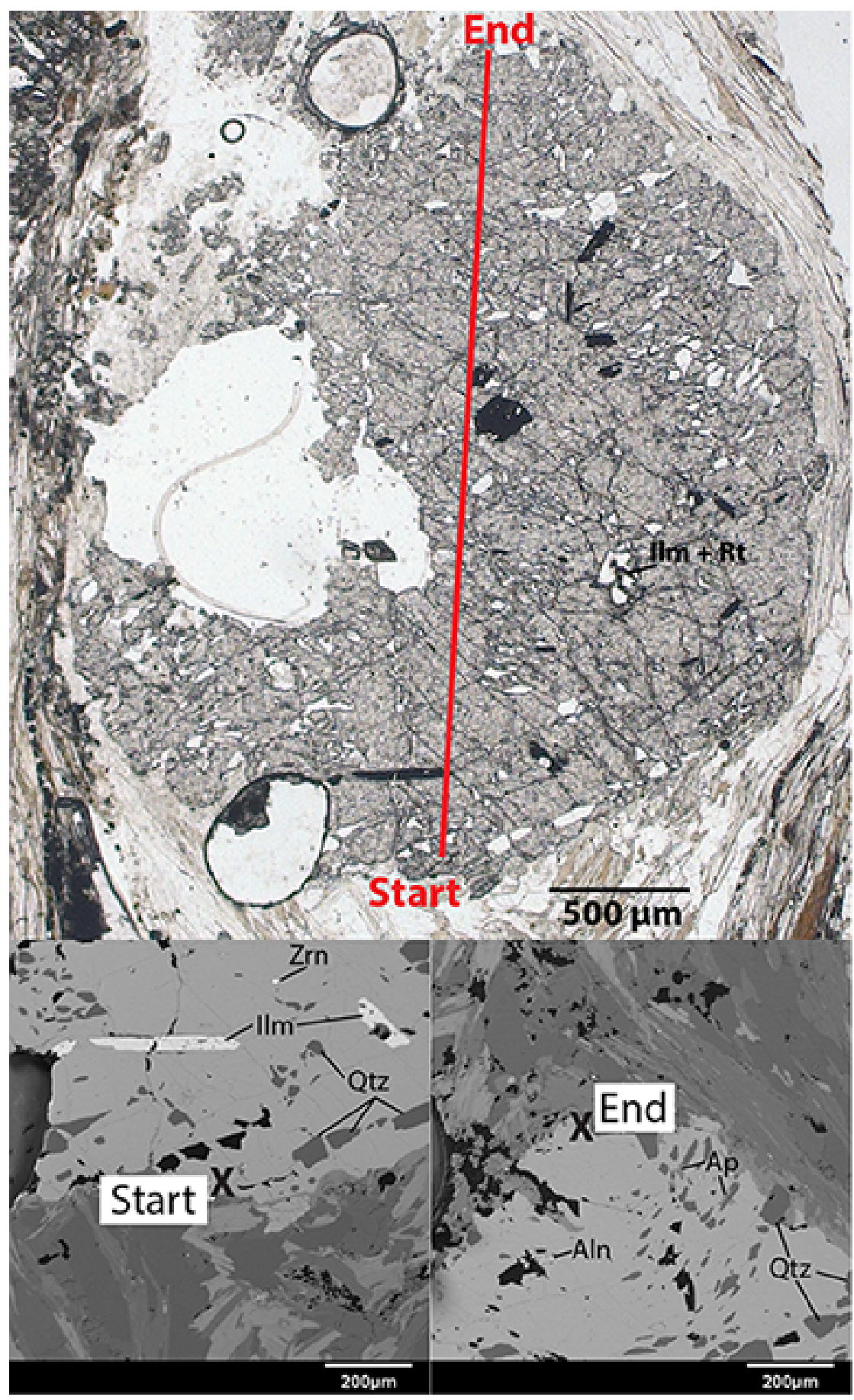


15RAYJR241A

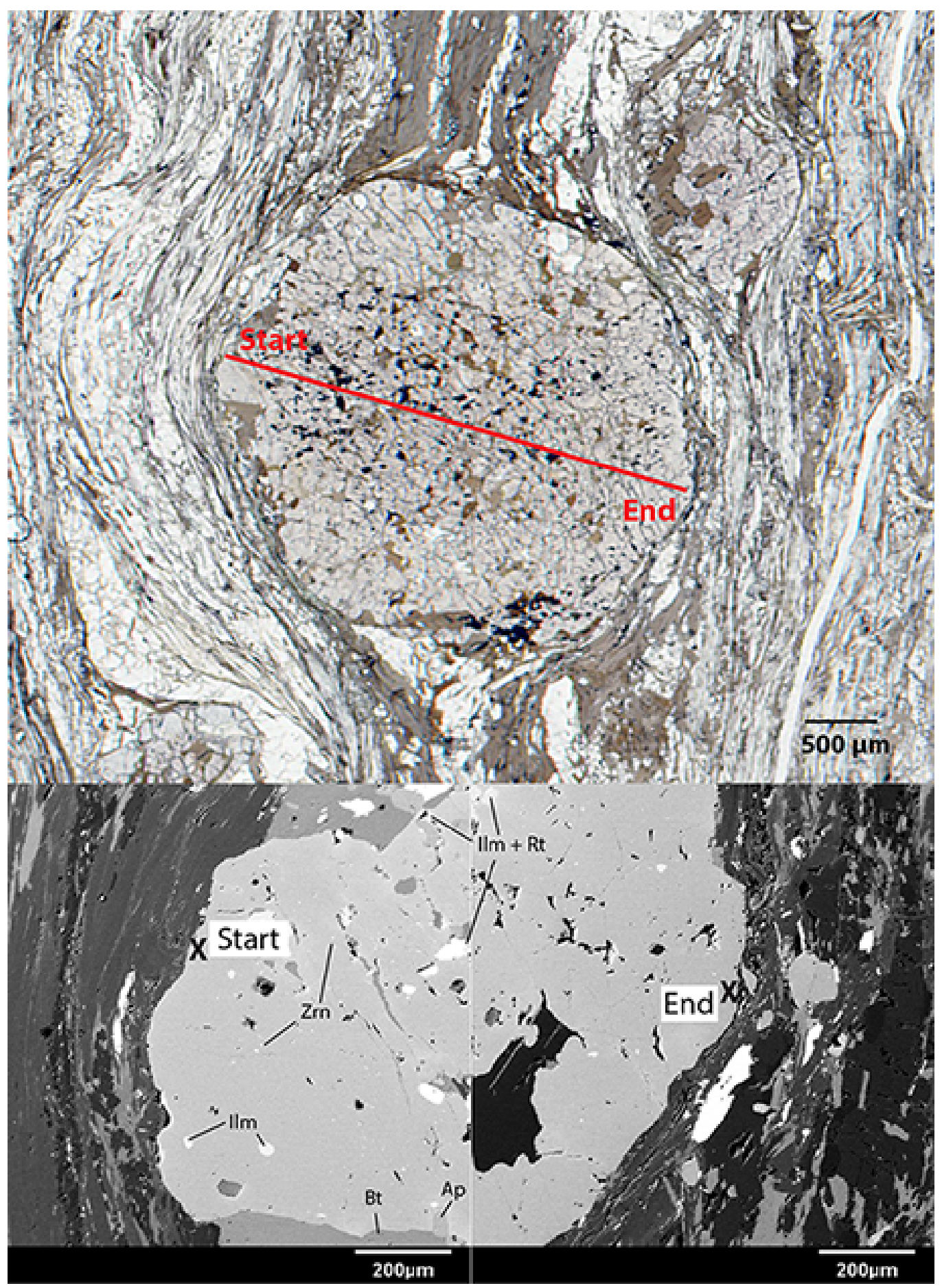


OORAY098A - 1

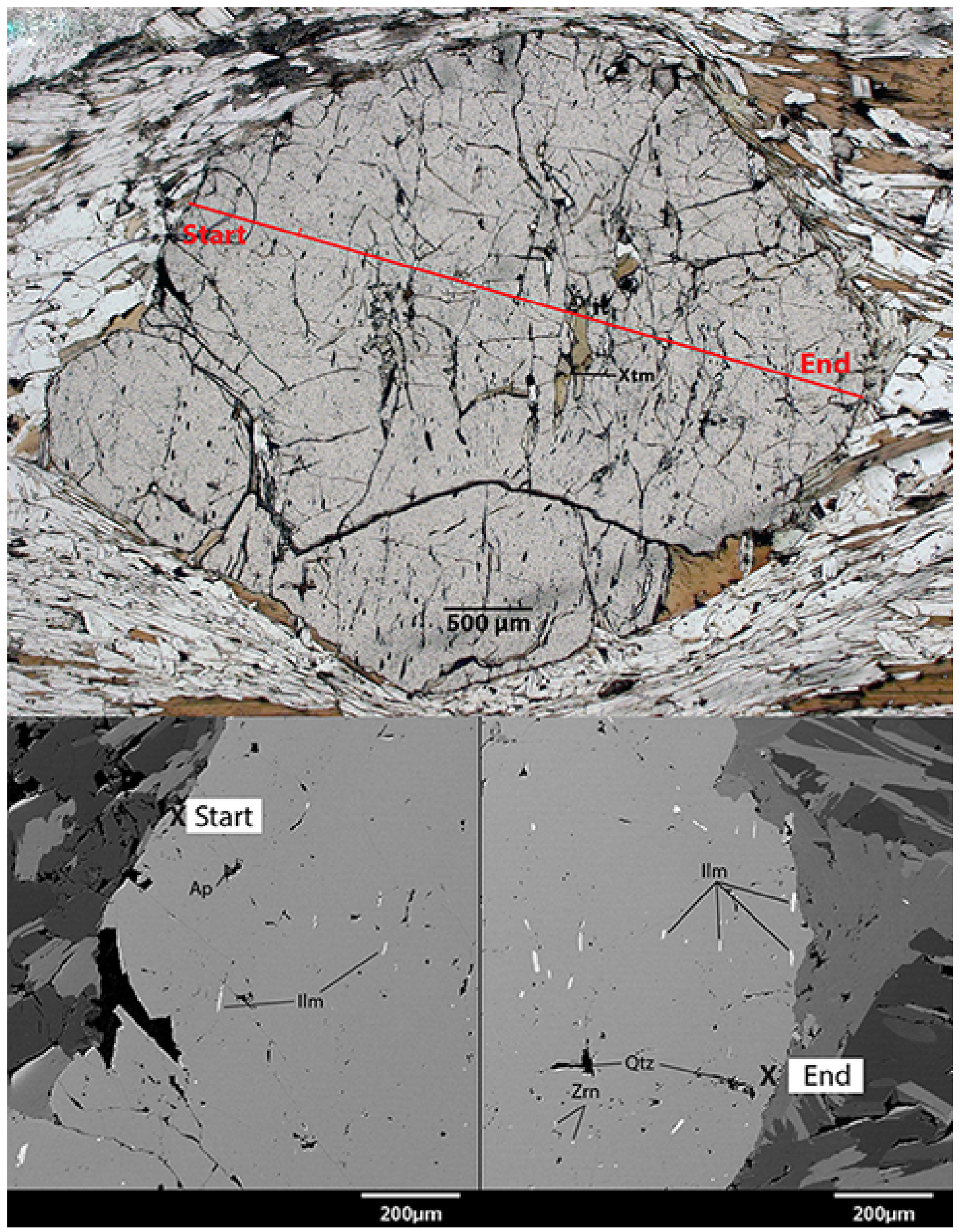


OORAY098A - 2

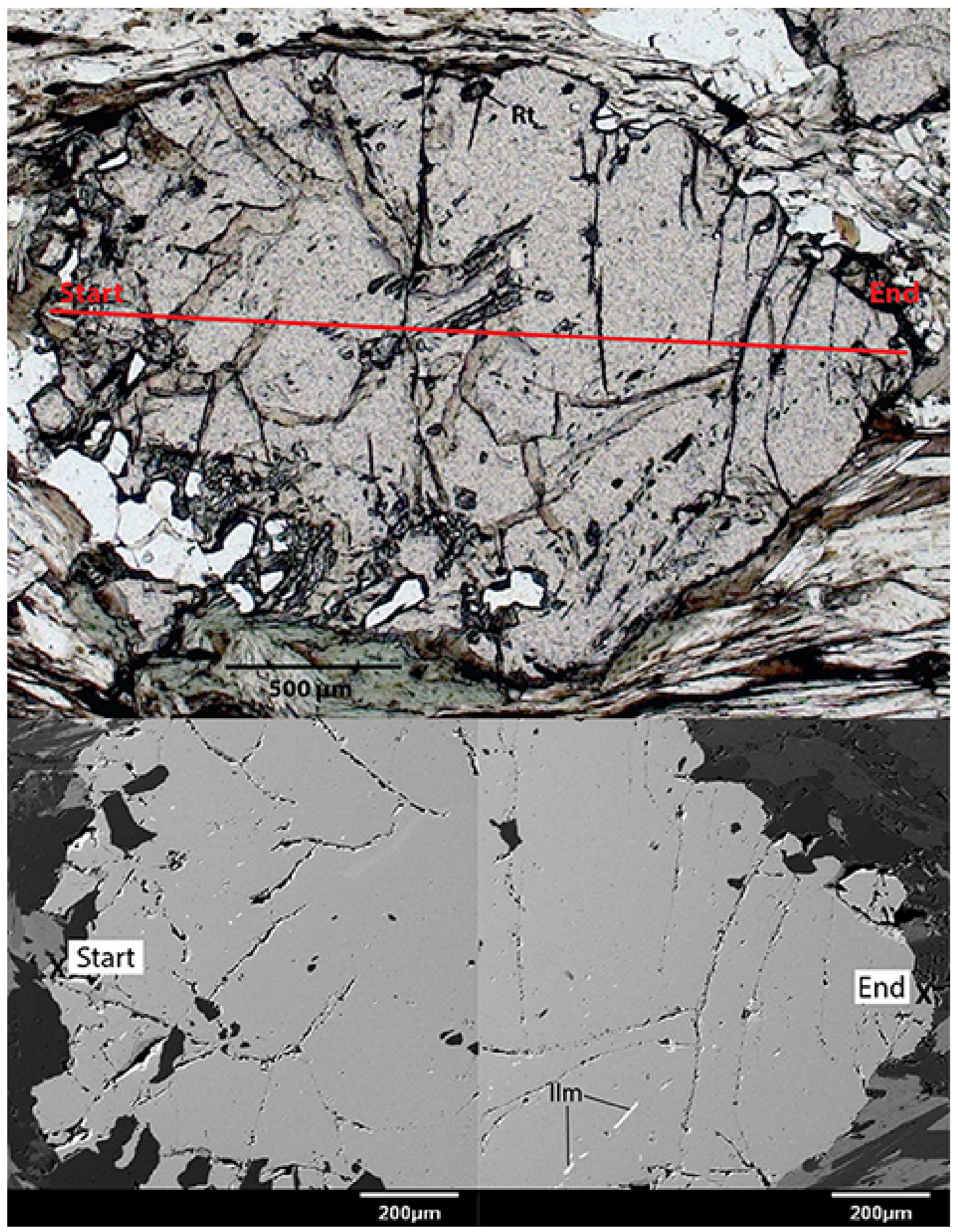


O0RAY231A

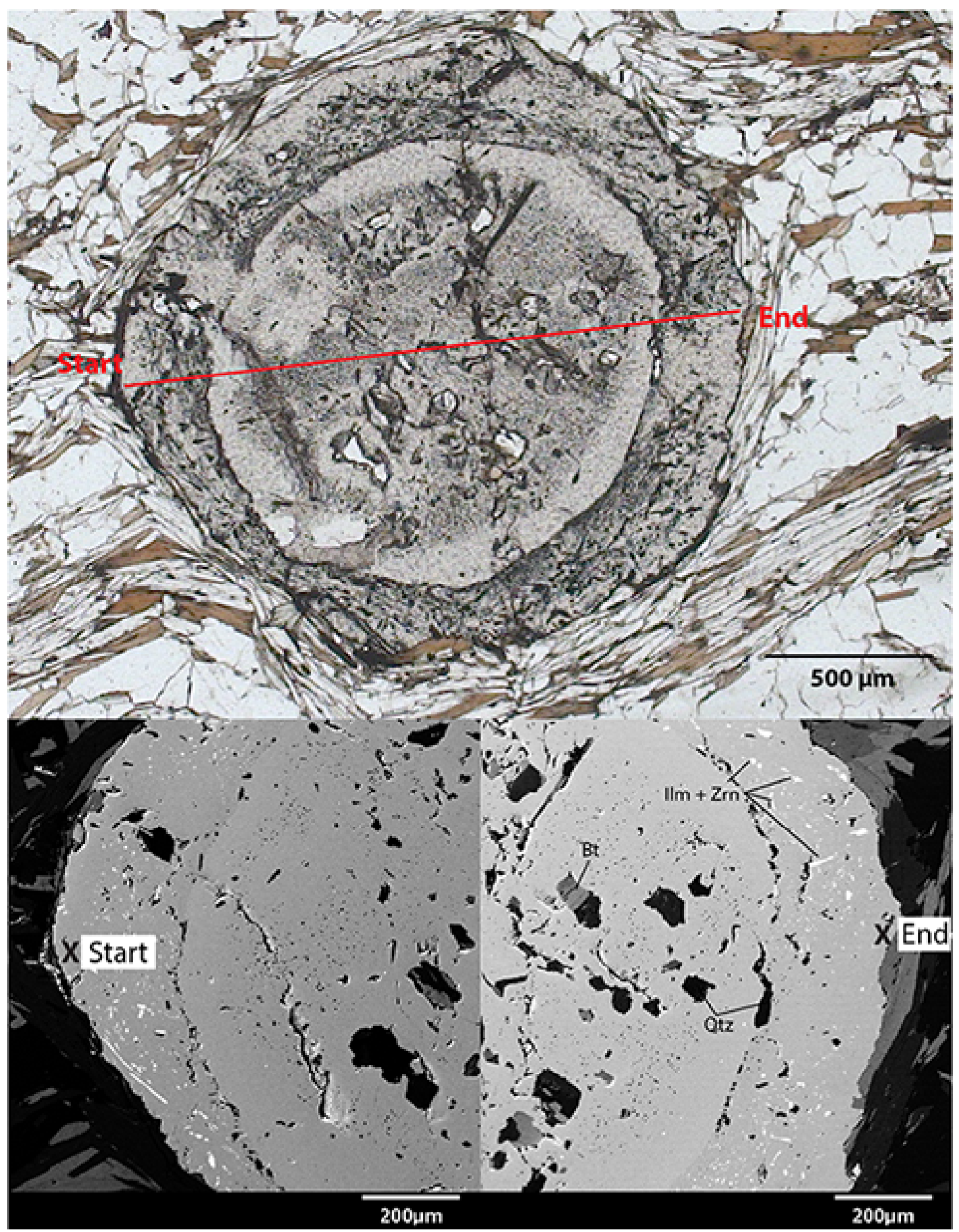


11RAYJR070A

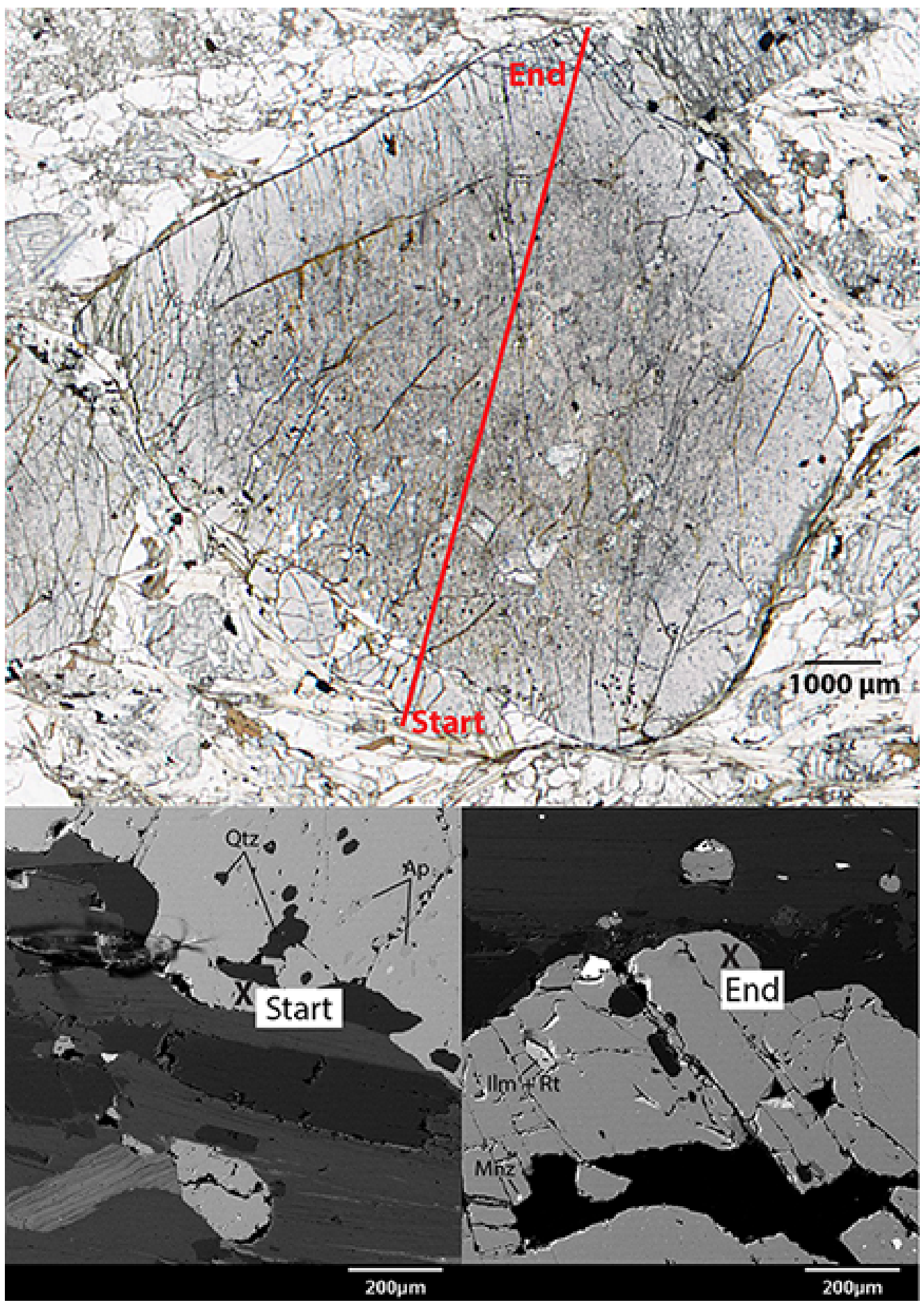


10RAYJR049A - 1

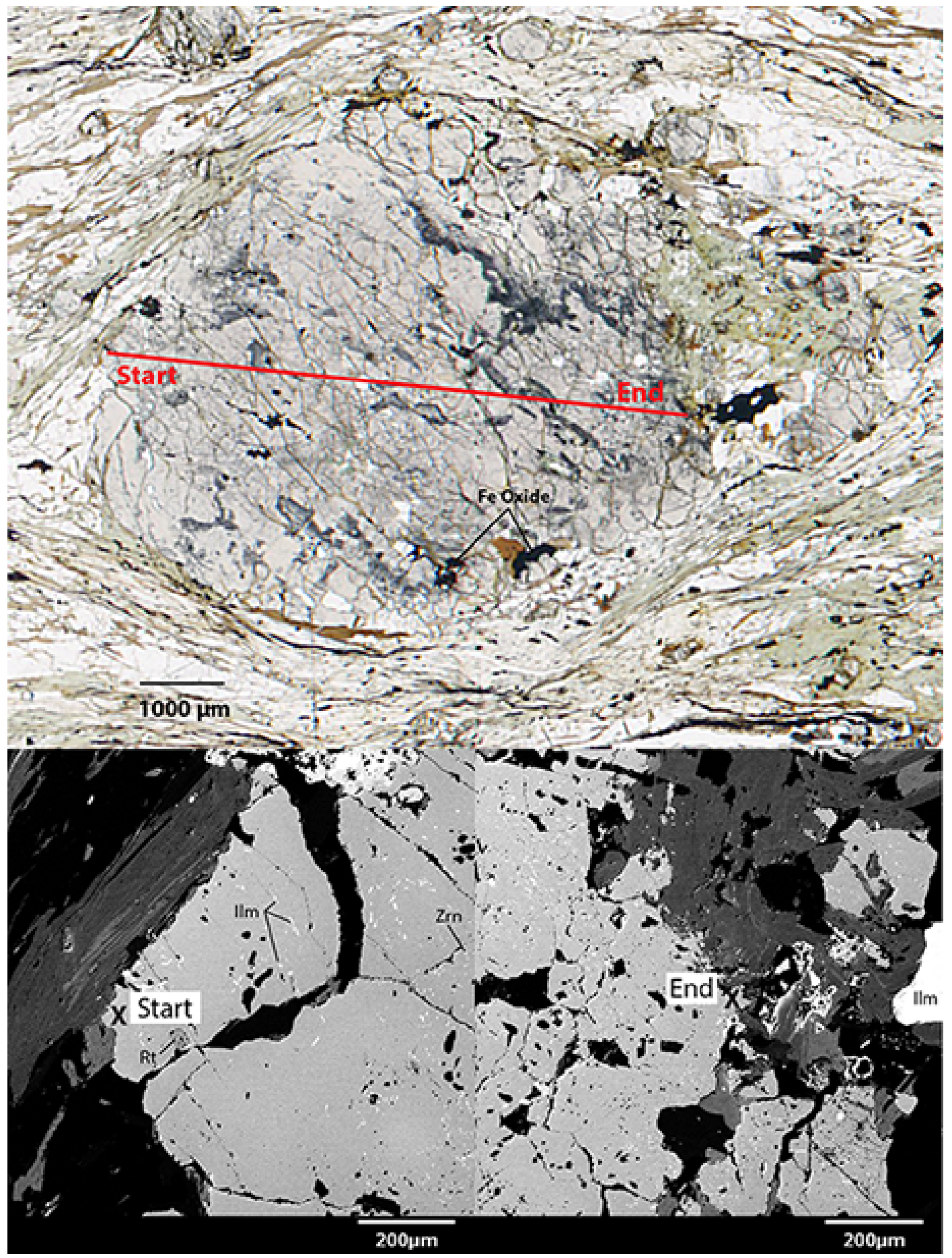


10RAYJR049A - 2

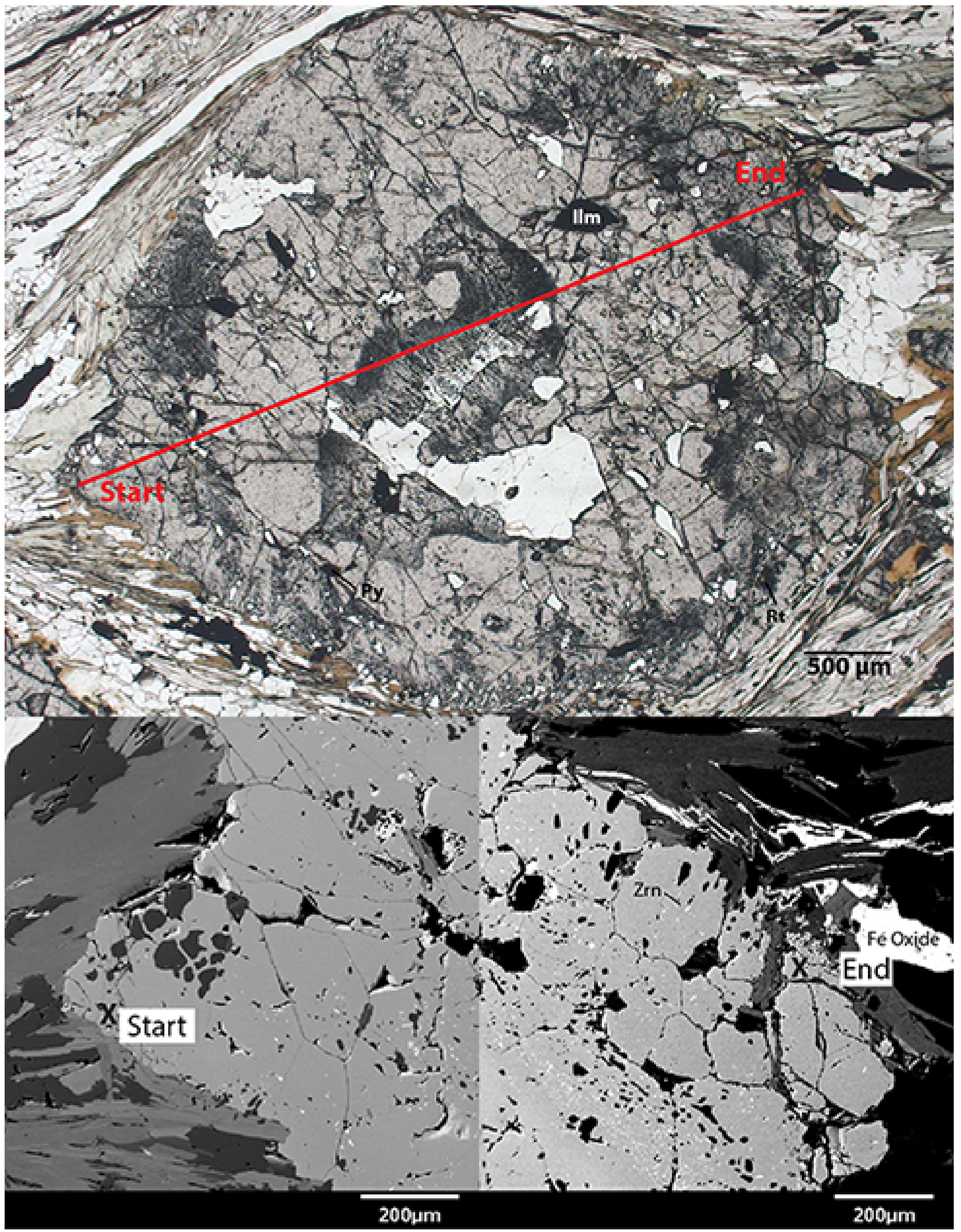




\section{Appendix C - EMPA mineral analyses}

Mineral analyses on samples from the NW and central groups using the electron microprobe

analyzer.

\begin{tabular}{|c|c|c|c|c|c|c|c|c|c|c|c|c|c|c|c|c|}
\hline \begin{tabular}{|l} 
Sample \& \\
Mineral
\end{tabular} & $\mathrm{SiO}_{2}$ & $\mathrm{TiO}_{2}$ & $\mathrm{Al}_{2} \mathrm{O}_{3}$ & $\mathrm{FeO}$ & $\mathrm{MnO}$ & MgO & $\mathrm{CaO}$ & $\mathrm{Na}_{2} \mathrm{O}$ & K2O & $\mathrm{Cr}_{2} \mathrm{O}_{3}$ & $\mathrm{BaO}$ & $\mathrm{Cl}$ & $\mathrm{NiO}$ & $\mathrm{ZnO}$ & $\mathbf{F}$ & Total \\
\hline \multicolumn{17}{|l|}{ 15RAYJR237B } \\
\hline Rutile & 0.14 & 100.10 & 0.09 & 0.23 & 0.01 & 0.00 & 0.07 & 0.00 & 0.00 & 0.00 & 0.00 & 0.00 & 0.00 & 0.00 & 0.00 & 100.64 \\
\hline White Mica & 47.04 & 0.83 & 35.32 & 1.12 & 0.00 & 0.98 & 0.00 & 1.28 & 9.55 & 0.01 & 0.31 & 0.01 & 0.00 & 0.00 & 0.00 & 96.44 \\
\hline Chlorite & 27.16 & 0.02 & 19.75 & 27.46 & 0.11 & 11.31 & 0.05 & 0.00 & 0.07 & 0.05 & 0.06 & 0.00 & 0.00 & 0.00 & 0.00 & 86.04 \\
\hline \multicolumn{17}{|c|}{ 15RAYJR246A } \\
\hline IImenite & 0.04 & 53.67 & 0.08 & 43.18 & 1.28 & 0.01 & 0.18 & 0.00 & 0.00 & 0.00 & 0.00 & 0.00 & 0.00 & 0.00 & 0.00 & 98.46 \\
\hline Rutile & 0.03 & 100.38 & 0.04 & 0.84 & 0.00 & 0.00 & 0.10 & 0.00 & 0.00 & 0.00 & 0.00 & 0.00 & 0.00 & 0.00 & 0.00 & 101.39 \\
\hline Biotite & 35.61 & 2.32 & 17.54 & 21.50 & 0.02 & 8.66 & 0.02 & 0.11 & 9.21 & 0.03 & 0.16 & 0.02 & 0.00 & 0.00 & 0.33 & 95.52 \\
\hline White Mica & 47.43 & 0.80 & 33.37 & 1.63 & 0.00 & 1.40 & 0.00 & 0.83 & $\begin{array}{c}10.0 \\
6\end{array}$ & 0.02 & 0.25 & 0.00 & 0.00 & 0.00 & 0.00 & 95.80 \\
\hline \begin{tabular}{|l|} 
Chlorite \\
\end{tabular} & 24.74 & 0.01 & 21.36 & 28.31 & 0.05 & 12.14 & 0.03 & 0.00 & 0.03 & 0.00 & 0.00 & 0.00 & 0.00 & 0.00 & 0.07 & 86.74 \\
\hline \multicolumn{17}{|l|}{ 00RAY098A } \\
\hline Biotite & 37.10 & 1.60 & 18.17 & 18.89 & 0.04 & 9.78 & 0.00 & 0.20 & 9.38 & 0.00 & 0.09 & 0.04 & 0.00 & 0.00 & 0.70 & 95.99 \\
\hline White Mica & 47.28 & 0.43 & 34.95 & 1.21 & \begin{tabular}{|l|}
0.03 \\
\end{tabular} & 0.84 & 0.00 & 1.28 & 9.62 & 0.06 & 0.25 & 0.00 & 0.00 & 0.00 & 0.25 & 96.21 \\
\hline \begin{tabular}{|l|l|} 
IImenite \\
\end{tabular} & 0.00 & 51.65 & 0.08 & 46.40 & 0.21 & 0.14 & 0.12 & 0.00 & \begin{tabular}{|l|}
0.00 \\
\end{tabular} & 0.00 & 0.00 & 0.00 & 0.00 & 0.00 & 0.00 & 98.59 \\
\hline Chlorite & 25.25 & 0.11 & 22.00 & 26.04 & 0.08 & 13.76 & 0.00 & 0.00 & 0.01 & 0.02 & 0.00 & 0.00 & 0.00 & 0.00 & 0.74 & 88.01 \\
\hline Plagioclase & 65.98 & 0.00 & 22.14 & 0.05 & 0.00 & 0.00 & 3.30 & 9.92 & 0.12 & 0.00 & 0.00 & 0.00 & 0.00 & 0.00 & 0.00 & 101.51 \\
\hline Goethite 1 & 2.26 & 0.00 & 0.02 & 73.73 & 0.02 & 0.01 & 0.00 & 0.00 & 0.00 & 0.00 & 0.00 & 0.00 & 0.00 & 0.00 & 0.00 & 76.04 \\
\hline Goethite 2 & 1.92 & 0.03 & 0.08 & 74.83 & 0.02 & 0.00 & 0.00 & 0.00 & 0.00 & 0.01 & 0.00 & 0.00 & 0.00 & 0.00 & 0.00 & 76.89 \\
\hline \multicolumn{17}{|l|}{ 00RAY231A } \\
\hline Plagioclase 1 & 65.66 & 0.00 & 21.71 & 0.05 & 0.00 & 0.00 & 2.84 & 10.05 & 0.11 & 0.00 & 0.00 & 0.00 & 0.00 & 0.00 & 0.00 & 100.40 \\
\hline Plagioclase 2 & 66.63 & 0.00 & 21.72 & 0.10 & 0.00 & 0.00 & 2.75 & 10.34 & 0.09 & 0.00 & 0.00 & 0.00 & 0.00 & 0.00 & 0.00 & 101.64 \\
\hline Biotite & 36.12 & 1.67 & 17.50 & 18.50 & 0.14 & 10.44 & 0.01 & 0.20 & 9.34 & 0.01 & 0.18 & 0.00 & 0.00 & 0.00 & 0.50 & 94.62 \\
\hline White Mica & 47.39 & 0.72 & 33.49 & 1.52 & 0.03 & 1.35 & 0.00 & 1.02 & 9.98 & 0.05 & 0.24 & 0.01 & 0.00 & 0.00 & 0.79 & 96.58 \\
\hline \begin{tabular}{|l|} 
IImenite \\
\end{tabular} & 0.12 & 52.68 & 0.09 & 46.03 & 0.41 & 0.39 & 0.11 & 0.00 & 0.00 & 0.01 & 0.00 & 0.00 & 0.00 & 0.00 & 0.00 & 99.84 \\
\hline Rutile & 0.32 & 100.23 & 0.12 & 0.26 & 0.00 & 0.04 & 0.03 & 0.00 & 0.00 & 0.02 & 0.00 & 0.00 & 0.00 & 0.00 & 0.00 & 101.02 \\
\hline Chlorite & 25.58 & 0.07 & 22.04 & 24.47 & 0.32 & 14.66 & 0.01 & 0.00 & 0.01 & 0.02 & 0.00 & 0.00 & 0.00 & 0.00 & 0.00 & 87.19 \\
\hline
\end{tabular}


Appendix D - Input values for whole rock composition

Input values in mol \% for phase equilibrium modeling and garnet crystallization modeling. Grey

samples correspond to the representative samples for each group. "?" corresponds to the amount of

$O$ required for charge balance, and is calculated by the software. Equilibrium assemblage diagrams

for other samples (white) can be found in appendix F.

\begin{tabular}{|c|c|c|c|c|c|c|c|c|c|c|c|}
\hline & Si & $\mathrm{Ti}$ & $\mathrm{Al}$ & $\mathrm{Fe}^{2+}$ & Mn & Mg & $\mathrm{Ca}$ & $\mathrm{Na}$ & $\mathrm{K}$ & $\mathrm{H}$ & 0 \\
\hline 15RAYJR230A & 67.25 & 0.62 & 19.26 & 4.08 & 0.03 & 2.17 & 0.32 & 0.99 & 5.28 & 75 & $?$ \\
\hline 15RAYJR231A & 56.58 & 0.70 & 24.28 & 6.56 & 0.07 & 3.26 & 0.79 & 0.91 & 6.85 & 75 & $?$ \\
\hline 15RAYJR232A & 63.01 & 0.64 & 19.80 & 5.81 & 0.06 & 2.84 & 0.78 & 1.33 & 5.73 & 75 & $?$ \\
\hline 15RAYJR232A & 64.15 & 0.51 & 17.25 & 5.68 & 0.09 & 2.22 & 3.03 & 3.94 & 3.13 & 75 & $?$ \\
\hline 15RAYJR233A & 65.39 & 0.47 & 17.88 & 4.71 & 0.25 & 3.35 & 0.59 & 1.92 & 5.44 & 75 & $?$ \\
\hline 02RAY080A & 66.59 & 0.65 & 19.06 & 4.81 & 0.05 & 2.75 & 0.53 & 1.00 & 4.55 & 75 & $?$ \\
\hline 15RAYJR235A & 63.04 & 0.62 & 21.47 & 4.98 & 0.04 & 2.69 & 0.40 & 0.90 & 5.86 & 75 & $?$ \\
\hline 15RAYJR236B & 67.56 & 0.43 & 16.04 & 4.43 & 0.06 & 5.07 & 1.32 & 1.54 & 3.54 & 75 & $?$ \\
\hline 15RAYJR236B & 74.62 & 0.50 & 13.89 & 3.69 & 0.06 & 2.25 & 0.92 & 0.54 & 3.53 & 75 & $?$ \\
\hline 15RAYJR237B & 70.11 & 0.60 & 16.86 & 4.43 & 0.04 & 2.61 & 0.55 & 0.84 & 3.96 & 75 & $?$ \\
\hline 15RAYJR244A & 67.65 & 0.51 & 17.57 & 4.69 & 0.08 & 2.73 & 1.06 & 0.84 & 4.87 & 75 & $?$ \\
\hline 15RAYJR244A & 63.26 & 0.50 & 20.77 & 4.73 & 0.06 & 2.38 & 0.88 & 0.83 & 6.57 & 75 & $?$ \\
\hline 15RAYJR245A & 61.72 & 0.69 & 19.73 & 5.93 & 0.16 & 3.59 & 1.08 & 1.40 & 5.68 & 75 & $?$ \\
\hline 15RAYJR246A & 55.70 & 0.62 & 23.97 & 6.71 & 0.09 & 3.26 & 1.21 & 1.14 & 7.30 & 75 & $?$ \\
\hline 02RAYG039C & 68.43 & 0.56 & 17.49 & 4.80 & 0.11 & 2.37 & 0.64 & 1.12 & 4.50 & 75 & $?$ \\
\hline 02RAYG141A & 56.43 & 0.71 & 26.66 & 5.24 & 0.07 & 2.42 & 0.39 & 1.24 & 6.85 & 75 & $?$ \\
\hline 15RAYJR248A & 61.13 & 0.56 & 20.18 & 5.75 & 0.07 & 3.10 & 1.43 & 1.62 & 6.16 & 75 & $?$ \\
\hline 15RAYJR249A & 70.88 & 0.43 & 16.20 & 2.98 & 0.05 & 1.84 & 0.80 & 1.91 & 4.90 & 75 & $?$ \\
\hline 15RAYJR239A & 55.61 & 0.69 & 25.92 & 6.52 & 0.17 & 3.20 & 0.14 & 1.27 & 6.47 & 75 & $?$ \\
\hline 15RAYJR240A & 69.87 & 0.48 & 14.95 & 3.85 & 0.02 & 3.41 & 2.43 & 1.77 & 3.21 & 75 & $?$ \\
\hline 15RAYJR241A & 53.13 & 1.08 & 22.14 & 7.43 & 0.27 & 4.77 & 1.42 & 2.59 & 7.17 & 75 & $?$ \\
\hline 15RAYJR243A & 70.63 & 0.58 & 15.60 & 4.96 & 0.09 & 2.31 & 0.23 & 0.57 & 5.03 & 75 & $?$ \\
\hline 15RAYJR242A & 53.70 & 0.88 & 23.75 & 8.07 & 0.25 & 3.52 & 0.39 & 0.88 & 8.57 & 75 & $?$ \\
\hline 15RAYJR242B & 70.21 & 0.49 & 14.32 & 4.71 & 0.13 & 2.15 & 0.93 & 2.22 & 4.83 & 75 & $?$ \\
\hline 00GGA218A & 66.41 & 0.54 & 15.32 & 4.42 & 0.08 & 4.22 & 3.54 & 1.89 & 3.59 & 75 & $?$ \\
\hline 00RAY098A & 55.96 & 0.48 & 22.96 & 5.76 & 0.05 & 4.60 & 1.37 & 1.42 & 7.41 & 75 & $?$ \\
\hline 00RAY166A & 62.65 & 0.53 & 19.54 & 4.07 & 0.08 & 2.31 & 2.43 & 3.70 & 4.69 & 75 & $?$ \\
\hline 00RAY129A & 73.63 & 0.17 & 13.42 & 2.96 & 0.06 & 1.20 & 2.47 & 3.40 & 2.70 & 75 & $?$ \\
\hline 00RAY231A & 60.48 & 0.72 & 20.12 & 6.13 & 0.28 & 3.88 & 0.92 & 1.87 & 5.60 & 75 & $?$ \\
\hline 11RAYTD056A & 58.19 & 1.03 & 22.10 & 7.21 & 0.11 & 4.33 & 0.97 & 2.11 & 3.96 & 75 & $?$ \\
\hline 11RAYTK008A & 72.65 & 0.48 & 15.25 & 3.76 & 0.09 & 1.96 & 0.55 & 0.86 & 4.41 & 75 & $?$ \\
\hline 03GGAR040A & 58.66 & 0.66 & 22.45 & 5.46 & 0.16 & 3.43 & 0.59 & 1.73 & 6.86 & 75 & $?$ \\
\hline 01RAY258A & 40.60 & 1.20 & 39.39 & 9.48 & 0.15 & 1.08 & 1.02 & 5.34 & 1.76 & 75 & $?$ \\
\hline 11RAYJR070A & 47.27 & 1.41 & 29.53 & 8.64 & 0.14 & 2.39 & 3.74 & 2.54 & 4.34 & 75 & $?$ \\
\hline 11RAYAZ421A & 56.10 & 1.08 & 23.49 & 7.55 & 0.09 & 3.49 & 0.96 & 2.16 & 5.06 & 75 & $?$ \\
\hline 10RAYJR049A & 58.72 & 0.91 & 20.60 & 7.04 & 0.10 & 3.95 & 1.45 & 2.50 & 4.74 & 75 & $?$ \\
\hline
\end{tabular}




\section{Appendix E - Thermodynamic database}

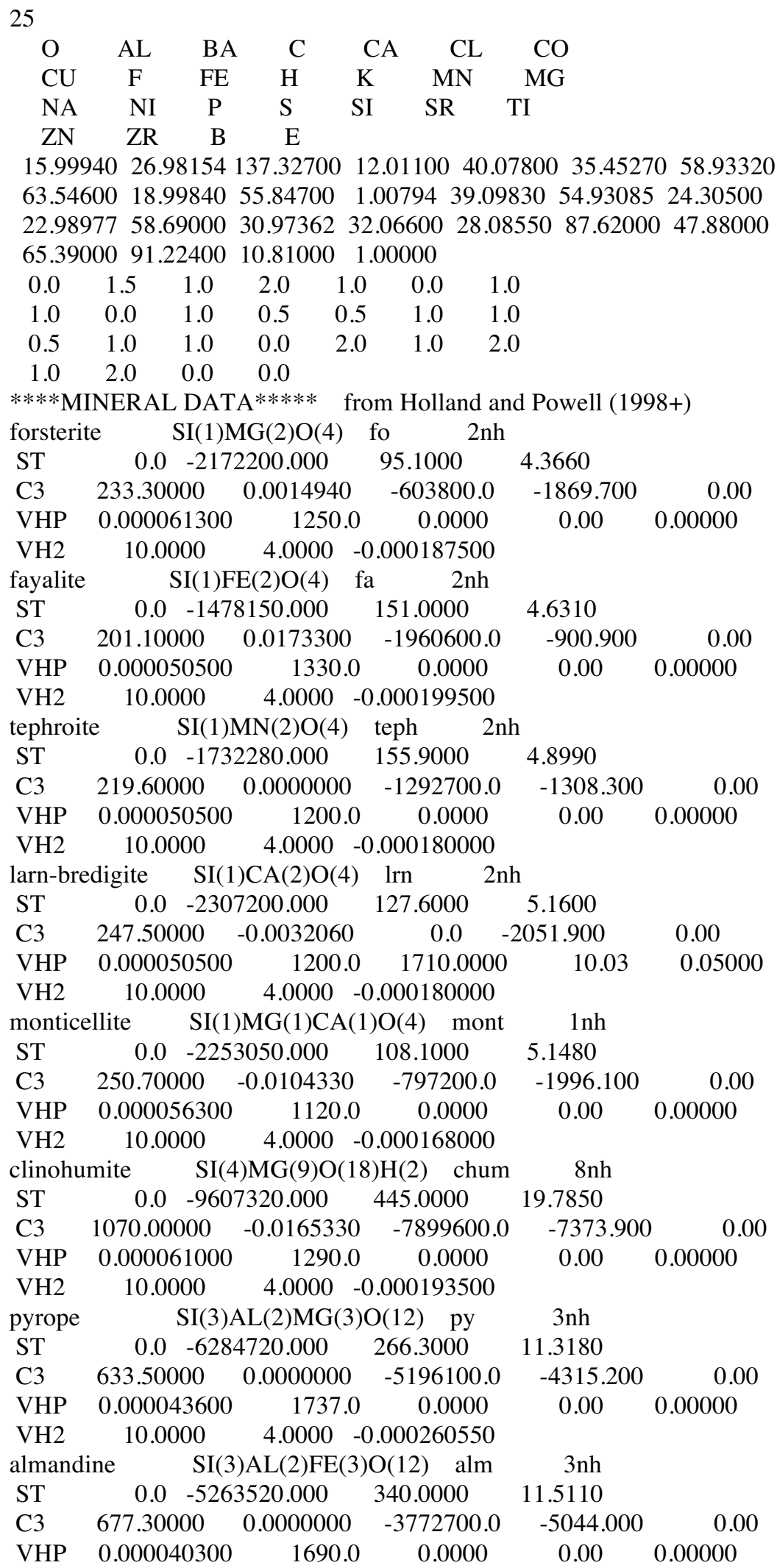




\begin{tabular}{|c|c|c|c|c|c|c|}
\hline \multirow{2}{*}{$\begin{array}{l}\mathrm{VH} 2 \\
\text { spessartine }\end{array}$} & 10.0000 & \multicolumn{2}{|c|}{$4.0000 \quad-0.000253500$} & \multirow[b]{2}{*}{$3 \mathrm{nh}$} & & \\
\hline & tine $\quad$ SI(3) & \multicolumn{2}{|c|}{$\operatorname{SI}(3) \mathrm{AL}(2) \mathrm{MN}(3) \mathrm{O}(12) \quad$ spss } & & & \\
\hline ST & -5646 & -5646400.000 & 367.0000 & \multicolumn{3}{|l|}{11.7920} \\
\hline $\mathrm{C} 3$ & 584.60000 & -0.0015930 & -7516700.0 & -2750.100 & & .00 \\
\hline VHP & 0.000046200 & $\quad 1790.0$ & 0.0000 & \multirow[t]{2}{*}{0.00} & \\
\hline VH2 & 10.0000 & \multicolumn{2}{|c|}{$4.0000-0.000268500$} & & \multicolumn{2}{|c|}{0.00000} \\
\hline grossul & & \multicolumn{2}{|c|}{$\mathrm{SI}(3) \mathrm{AL}(2) \mathrm{CA}(3) \mathrm{O}(12) \mathrm{gr}$} & \multicolumn{3}{|l|}{$3 \mathrm{nh}$} \\
\hline $\mathrm{ST}$ & $0.0-6644$ & -6644150.000 & 255.0000 & \multicolumn{3}{|l|}{12.5350} \\
\hline $\mathrm{C} 3$ & 626.00000 & 0.0000000 & -5779200.0 & -4002.900 & & .00 \\
\hline VHP & 0.000039300 & 1680.0 & 0.0000 & 0.00 & 0.00000 & \\
\hline VH2 & 10.0000 & $4.0000-0$ & 0.000252000 & & & \\
\hline andrad & $\mathrm{SI}(3) \mathrm{I}$ & $\mathrm{FE}(2) \mathrm{CA}(3) \mathrm{C}$ & $\mathrm{O}(12)$ andr & $3 \mathrm{nh}$ & & \\
\hline ST & $0.0-5768$ & 58130.000 & 318.0000 & 13.2040 & & \\
\hline $\mathrm{C} 3$ & 638.60000 & 0.0000000 & -4955100.0 & -3989.200 & & .00 \\
\hline VHP & 0.000039300 & $\quad 1590.0$ & 0.0000 & 0.00 & 0.00000 & \\
\hline VH2 & 10.0000 & $4.0000-0$ & 0.000238500 & & & \\
\hline osumil & itE_1 SI(1 & 10)AL(5)MG & $(2) \mathrm{K}(1) \mathrm{O}(30)$ & osm1 & $2 \mathrm{nh}$ & \\
\hline $\mathrm{ST}$ & $0.0-1496$ & 67900.000 & 701.0000 & 37.8930 & & \\
\hline $\mathrm{C} 3$ & 1625.80000 & -0.0355480 & -8063500.0 & -13490.900 & & 0.00 \\
\hline VHP & 0.000007600 & 810.0 & 0.0000 & $0.00 \quad 0$ & 0.00000 & \\
\hline VH2 & 10.0000 & $4.0000-0$ & 0.000121500 & & & \\
\hline osumil & itE_2 SI(1 & 11)AL(3)MG & $(3) \mathrm{K}(1) \mathrm{O}(30)$ & osm2 & $3 \mathrm{nh}$ & \\
\hline ST & $0.0-1480$ & 09710.000 & 724.0000 & 38.4400 & & \\
\hline $\mathrm{C} 3$ & 1610.60000 & -0.0344570 & -8262100.0 & -13128.800 & & 0.00 \\
\hline VHP & 0.000007600 & 810.0 & 0.0000 & $0.00 \quad 0$ & 0.00000 & \\
\hline VH2 & 10.0000 & $4.0000-0$ & 0.000121500 & & & \\
\hline $\mathrm{Fe}-\mathrm{osu}$ & milite $\quad \mathrm{SI}(1$ & 10)AL(5)FE(2 & 2) $\mathrm{K}(1) \mathrm{O}(30)$ & fosm & $\mathrm{ah}$ & \\
\hline ST & $\begin{array}{lll}0.0 & -1424\end{array}$ & 48330.000 & 762.0000 & 38.3200 & & \\
\hline C3 & 1656.00000 & -0.0341630 & -6497700.0 & -14114.300 & & 0.00 \\
\hline VHP & 0.000008000 & 800.0 & 0.0000 & $0.00 \quad 0$ & 0.00000 & \\
\hline VH2 & 10.0000 & $4.0000-0$ & 0.000120000 & & & \\
\hline osumil & itE_1 SI(1 & 10)AL(5)MG & $(2) \mathrm{K}(1) \mathrm{O}(30)$ & osm1 & $2 \mathrm{nh}$ & \\
\hline ST & $0.0-1496$ & 68190.000 & 701.0000 & 37.8930 & & \\
\hline $\mathrm{C} 3$ & 1625.80000 & -0.0355480 & -8063500.0 & -13490.900 & & 0.00 \\
\hline VHP & 0.000007600 & 810.0 & 0.0000 & $0.00 \quad 0$ & 0.00000 & \\
\hline VH2 & 10.0000 & $4.0000-0$ & 0.000121500 & & & \\
\hline osumil & itE_2 SI(1 & 11)AL(3)MG & $(3) \mathrm{K}(1) \mathrm{O}(30)$ & osm2 & $3 \mathrm{nh}$ & \\
\hline ST & $\begin{array}{lll}0.0 & -1481\end{array}$ & 10340.000 & 724.0000 & 38.4400 & & \\
\hline $\mathrm{C} 3$ & 1610.60000 & -0.0344570 & -8262100.0 & -13128.800 & & 0.00 \\
\hline VHP & 0.000007600 & 810.0 & 0.0000 & $0.00 \quad 0$ & 0.00000 & \\
\hline VH2 & 10.0000 & $4.0000-0$ & 0.000121500 & & & \\
\hline $\mathrm{Fe}-\mathrm{osu}$ & milite $\quad$ SI (1 & 10)AL(5)FE(2 & 2) $\mathrm{K}(1) \mathrm{O}(30)$ & fosm & $\mathrm{nh}$ & \\
\hline ST & $\begin{array}{lll}0.0 & -1424\end{array}$ & 48460.000 & 762.0000 & 38.3200 & & \\
\hline $\mathrm{C} 3$ & 1656.00000 & -0.0341630 & -6497700.0 & -14114.300 & & 0.00 \\
\hline VHP & 0.000008000 & 800.0 & 0.0000 & $0.00 \quad 0$ & 0.00000 & \\
\hline VH2 & 10.0000 & $4.0000-0$ & 0.000120000 & & & \\
\hline vesuvic & anite $\quad$ SI(18 & 18)AL(11)MG & $\mathrm{J}(2) \mathrm{CA}(19) \mathrm{O}(7$ & 78)H(9) vsv & & $\operatorname{lnh}$ \\
\hline ST & $\begin{array}{lll}0.0 & -4235\end{array}$ & 52670.000 & 1890.0000 & 85.2000 & & \\
\hline $\mathrm{C} 3$ & 4488.00000 & -0.0579520 & -22269300.0 & -33478.000 & & 0.00 \\
\hline VHP & 0.000050000 & $\quad 1670.0$ & 0.0000 & 0.00 & 0.00000 & \\
\hline VH2 & 10.0000 & $4.0000-0$ & 0.000250500 & & & \\
\hline andalu & site $\quad \mathrm{SI}(1)$ & $\mathrm{AL}(2) \mathrm{O}(5)$ & and $\quad \operatorname{lnh}$ & & & \\
\hline $\mathrm{ST}$ & $0.0-2588$ & 38800.000 & 92.7000 & 5.1530 & & \\
\hline $\mathrm{C} 3$ & 277.30000 & -0.0065880 & -1914100.0 & -2265.600 & & .00 \\
\hline VHP & 0.000041100 & $\quad 1334.0$ & 0.0000 & 0.00 & 0.00000 & \\
\hline VH2 & 10.0000 & $4.0000-0$ & 0.000200100 & & & \\
\hline
\end{tabular}




\begin{tabular}{|c|c|c|c|c|c|}
\hline kyanite & \multicolumn{3}{|c|}{ SI(1)AL(2)O(5) ky $\quad$ 1nh } & \\
\hline ST & \multicolumn{2}{|c|}{$0.0-2593110.000$} & \multirow{2}{*}{$\begin{array}{l}83.5000 \\
-2055600.0\end{array}$} & \multicolumn{2}{|l|}{4.4140} \\
\hline $\mathrm{C} 3$ & 279.40000 & -0.0071240 & & \multicolumn{2}{|l|}{-2289.400} \\
\hline VHP & 0.000040400 & $\quad 1590.0$ & 0.0000 & \multirow[t]{2}{*}{0.00} & \\
\hline VH2 & 10.0000 & \multicolumn{2}{|c|}{$4.0000-0.000238500$} & & 0.00000 \\
\hline \multicolumn{3}{|c|}{ sillimanite $\quad \mathrm{SI}(1) \mathrm{AL}(2) \mathrm{O}(5)$} & sill $\quad$ lnh & \\
\hline ST & \multicolumn{2}{|c|}{$0.0 \quad-2585680.000$} & 95.5000 & \multicolumn{2}{|l|}{4.9860} \\
\hline $\mathrm{C} 3$ & 280.20000 & -0.0069000 & -1375700.0 & -2399.400 & 0.00 \\
\hline VHP & 0.000022100 & $\quad 1320.0$ & 2200.0000 & 4.00 & 0.03500 \\
\hline VH2 & 10.0000 & $4.0000-0$ & 0.000198000 & & \\
\hline hydrox & y-topaz SI & $\mathrm{I}(1) \mathrm{AL}(2) \mathrm{O}(6)$ & $\mathrm{H}(2) \quad \operatorname{tpz}$ & $1 \mathrm{nh}$ & \\
\hline ST & $0.0-290$ & 4980.000 & 100.5000 & 5.3390 & \\
\hline $\mathrm{C} 3$ & 387.70000 & -0.0071200 & -857200.0 & -3744.200 & 0.00 \\
\hline VHP & 0.000040400 & $\quad 1315.0$ & 0.0000 & 0.00 & 0.00000 \\
\hline VH2 & 10.0000 & $4.0000-0$ & 0.000197250 & & \\
\hline Mg-sta & urolite $\quad \mathrm{SI}($ & (7.5)AL(18)M & $\mathrm{IG}(4) \mathrm{O}(48) \mathrm{H}(4$ & 4) $\mathrm{mst}$ & $4 \mathrm{nh}$ \\
\hline ST & $\begin{array}{lll}0.0 & -2510\end{array}$ & 01490.000 & 910.0000 & 44.2600 & \\
\hline C3 & 2820.50000 & -0.0593660 & -13774000.0 & -24126.000 & 0.00 \\
\hline VHP & 0.000012000 & $\quad 1200.0$ & 0.0000 & 0.00 & 0.00000 \\
\hline VH2 & 10.0000 & $4.0000-0$ & 0.000180000 & & \\
\hline Fe-stau & rolite $\quad \mathrm{SI}(7$ & 7.5)AL(18)FE & $(4) \mathrm{O}(48) \mathrm{H}(4)$ & fst $\quad 4 n$ & \\
\hline ST & $\begin{array}{lll}0.0 & -2375\end{array}$ & 53930.000 & 1010.0000 & 44.8800 & \\
\hline $\mathrm{C} 3$ & 2880.00000 & -0.0565950 & -10642000.0 & -25373.000 & 0.00 \\
\hline VHP & 0.000012000 & $\quad 1200.0$ & 0.0000 & 0.00 & 0.00000 \\
\hline VH2 & 10.0000 & $4.0000-0$ & 0.000180000 & & \\
\hline Mn-sta & urolite $\quad$ SI & (7.5)AL(18)M & $\mathrm{IN}(4) \mathrm{O}(48) \mathrm{H}(4$ & 4) mnst & $4 \mathrm{nh}$ \\
\hline $\mathrm{ST}$ & $0.0-2420$ & 03880.000 & 1024.0000 & 45.4600 & \\
\hline $\mathrm{C} 3$ & 2873.30000 & -0.0890640 & -12688000.0 & -24749.000 & $0 \quad 0.00$ \\
\hline VHP & 0.000012000 & $\quad 1200.0$ & 0.0000 & 0.00 & 0.00000 \\
\hline VH2 & 10.0000 & $4.0000-0$ & 0.000180000 & & \\
\hline Mg-chl & oritoid $\quad \mathrm{SI}$ & (1) $\mathrm{AL}(2) \mathrm{MG}($ & $(1) \mathrm{O}(7) \mathrm{H}(2)$ & $\operatorname{mctd}$ & hh \\
\hline ST & 0.0 & 51420.000 & 140.0000 & 6.8750 & \\
\hline C3 & 464.40000 & -0.0126540 & -1147200.0 & -4341.000 & 0.00 \\
\hline VHP & 0.000054200 & $\quad 1465.0$ & 0.0000 & 0.00 & 0.00000 \\
\hline VH2 & 10.0000 & $4.0000-0$ & 0.000219750 & & \\
\hline Fe-chlo & ritoid $\quad$ SI(1 & 1) $\mathrm{AL}(2) \mathrm{FE}(1)$ & $\mathrm{O}(7) \mathrm{H}(2)$ fct & td $\quad 1 \mathrm{nh}$ & \\
\hline $\mathrm{ST}$ & -321 & 5380.000 & 155.0000 & 6.9800 & \\
\hline $\mathrm{C} 3$ & 484.60000 & -0.0138080 & -198900.0 & -4762.200 & 0.00 \\
\hline VHP & 0.000054200 & $\quad 1465.0$ & 0.0000 & 0.00 & 0.00000 \\
\hline VH2 & 10.0000 & $4.0000-0$ & 0.000219750 & & \\
\hline Mn-chl & oritoid $\quad \mathrm{SI}$ & (1) $\mathrm{AL}(2) \mathrm{MN}($ & $(1) \mathrm{O}(7) \mathrm{H}(2)$ & mnctd & $\mathrm{nh}$ \\
\hline ST & $\begin{array}{lll}0.0 & -332\end{array}$ & 29280.000 & 166.0000 & 7.1750 & \\
\hline $\mathrm{C} 3$ & 464.40000 & -0.0126540 & -1147200.0 & -4341.000 & 0.00 \\
\hline VHP & 0.000054200 & $\quad 1465.0$ & 0.0000 & 0.00 & 0.00000 \\
\hline VH2 & 10.0000 & $4.0000-0$ & 0.000219750 & & \\
\hline merwin & iite $\quad \mathrm{SI}(2$ & 2) $\mathrm{MG}(1) \mathrm{CA}(3$ & 3) $\mathrm{O}(8)$ merw & $1 \mathrm{nh}$ & \\
\hline $\mathrm{ST}$ & $\begin{array}{lll}0.0 & -454\end{array}$ & 16420.000 & 253.1000 & 9.8470 & \\
\hline $\mathrm{C} 3$ & 417.50000 & 0.0081170 & -2923000.0 & -2320.300 & 0.00 \\
\hline VHP & 0.000061500 & $\quad 1200.0$ & 0.0000 & 0.00 & 0.00000 \\
\hline VH2 & 10.0000 & $4.0000-0$ & 0.000180000 & & \\
\hline spurrite & $\mathrm{SI}(2) \mathrm{C}$ & $\mathrm{CA}(5) \mathrm{O}(11) \mathrm{C}$ & (1) $\mathrm{spu}$ & $5 \mathrm{nh}$ & \\
\hline ST & $\begin{array}{ll}0.0 & -584\end{array}$ & 19520.000 & 330.0000 & 14.6970 & \\
\hline $\mathrm{C} 3$ & 614.10000 & -0.0035080 & -2493100.0 & -4168.000 & 0.00 \\
\hline VHP & 0.000065000 & 950.0 & 0.0000 & $0.00 \quad 0$ & 0.00000 \\
\hline VH2 & 10.0000 & $4.0000-0$ & 0.000142500 & & \\
\hline zoisite & $\mathrm{SI}(3) \mathrm{A}$ & $\mathrm{AL}(3) \mathrm{CA}(2) \mathrm{O}$ & $(13) \mathrm{H}(1) \quad$ zo & $1 \mathrm{nh}$ & \\
\hline
\end{tabular}




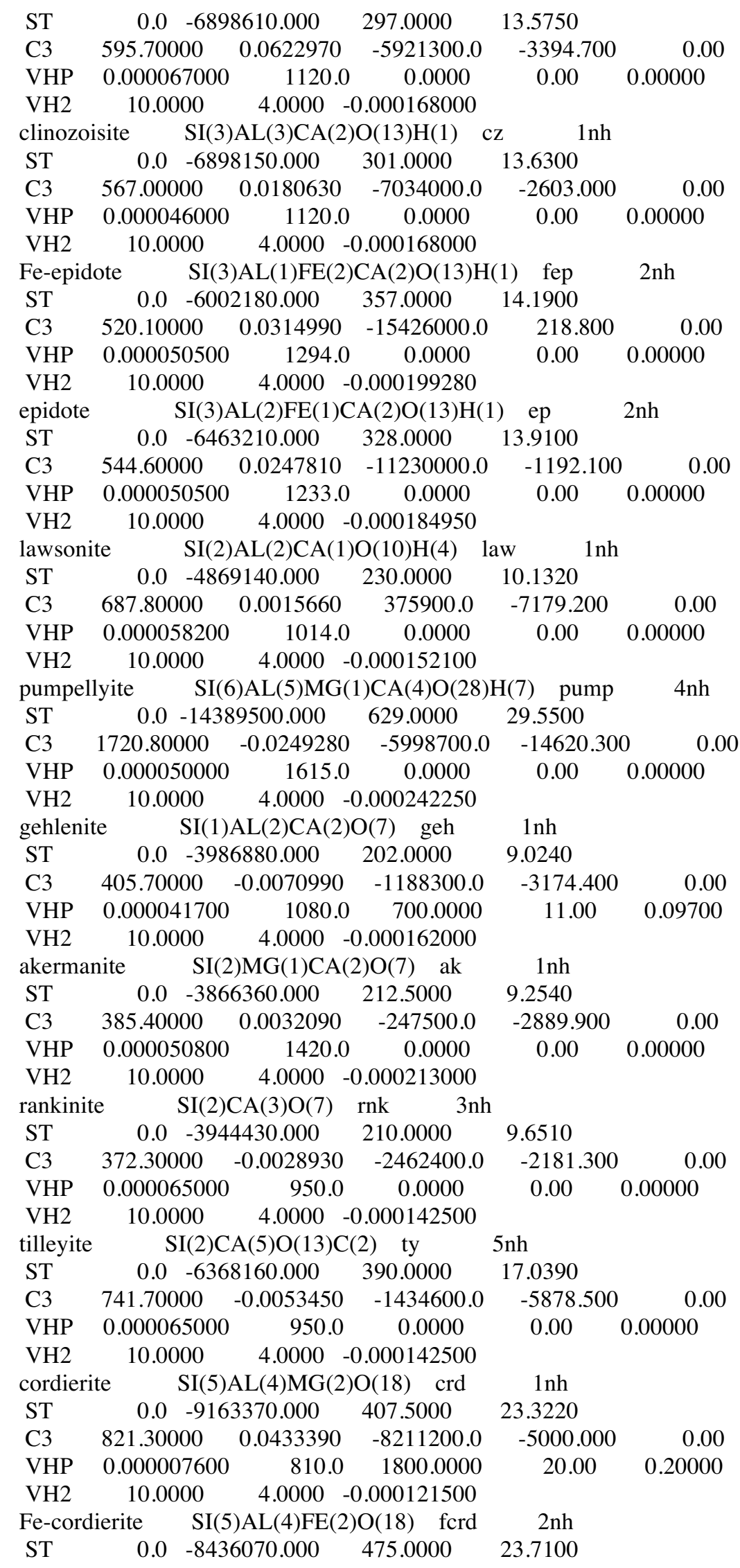




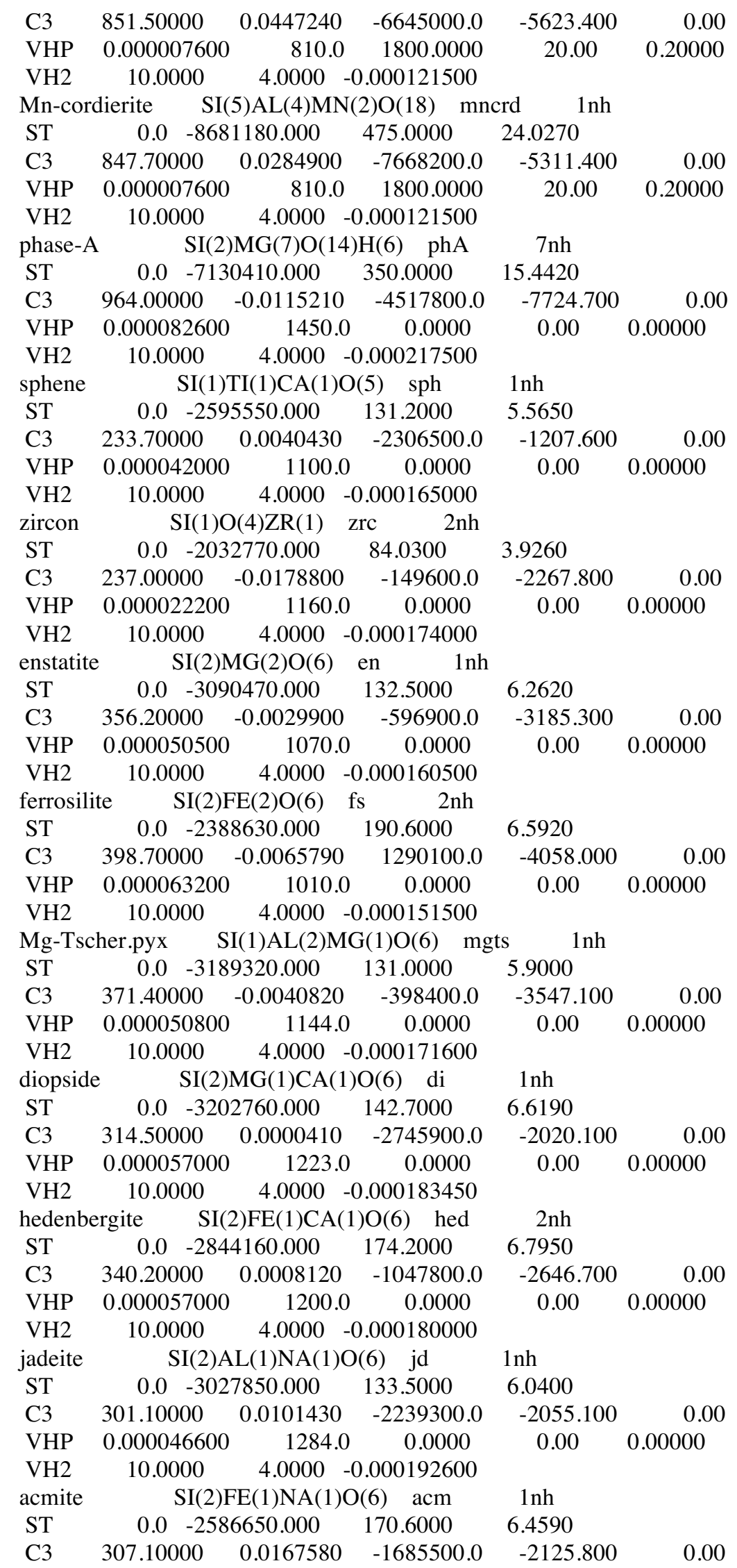




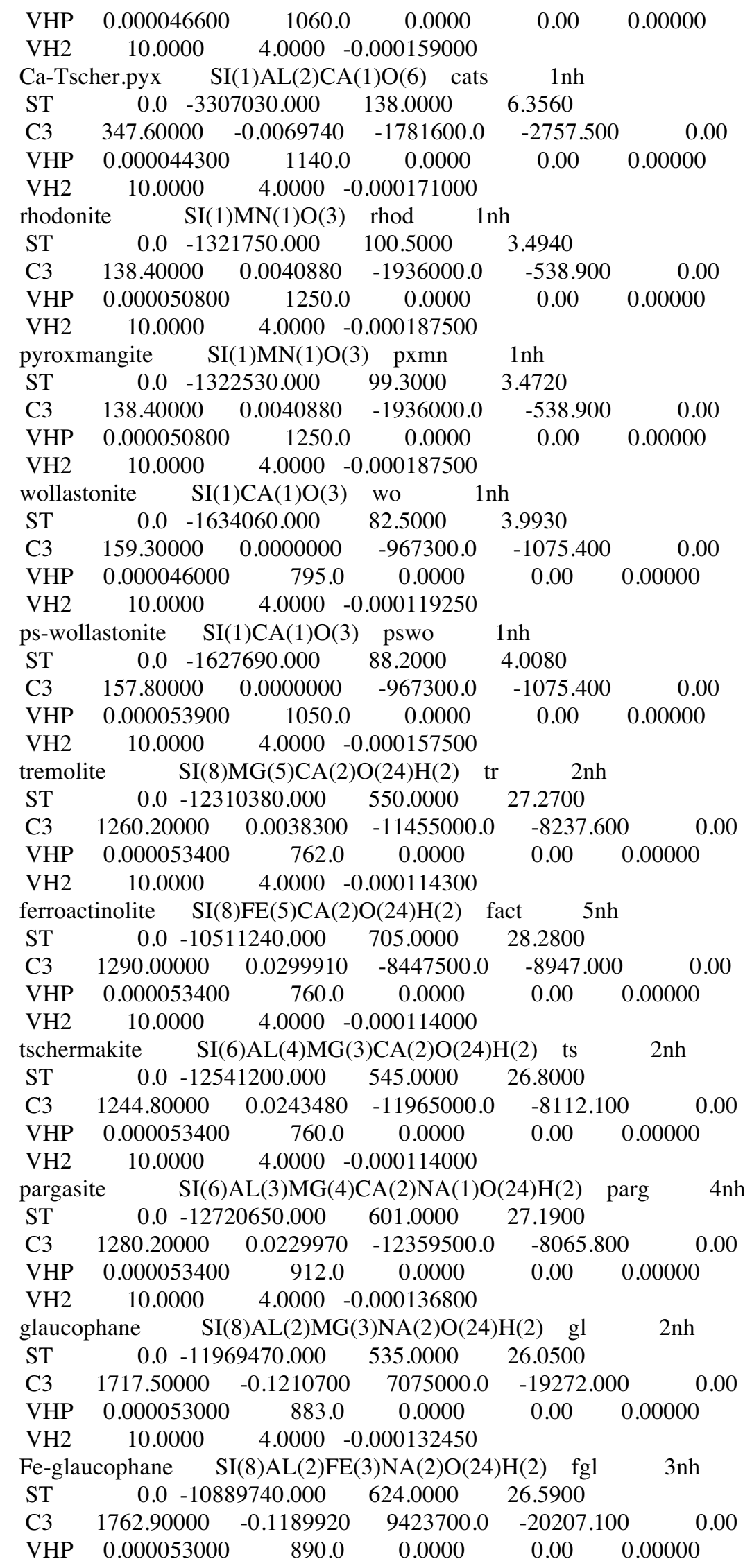




\begin{tabular}{|c|c|c|c|c|c|c|}
\hline VH2 & 10.0000 & $4.0000-0$ & 0.000133500 & & & \\
\hline riebecl & ite $\quad \mathrm{SI}(8)$ & $\mathrm{FE}(5) \mathrm{NA}(2) \mathrm{C}$ & $\mathrm{O}(24) \mathrm{H}(2)$ & $2 \mathrm{nh}$ & & \\
\hline ST & $0.0-1003$ & 35240.000 & 691.0000 & 27.4900 & & \\
\hline C3 & 1746.90000 & -0.1135720 & 9370300.0 & -19468.700 & & 0.00 \\
\hline VHP & 0.000053000 & 890.0 & 0.0000 & $0.00 \quad 0$ & 0.00000 & \\
\hline VH2 & 10.0000 & $4.0000-c$ & 0.000133500 & & & \\
\hline anthop & hyllite $\quad$ SI $(8$ & 8)MG(7)O(24 & 4) $\mathrm{H}(2)$ anth & $2 \mathrm{nh}$ & & \\
\hline ST & $\begin{array}{lll}0.0 & -1206\end{array}$ & 69200.000 & 536.0000 & 26.5400 & & \\
\hline C3 & 1277.30000 & 0.0258250 & -9704600.0 & -9074.700 & & 0.00 \\
\hline VHP & 0.000050000 & 700.0 & 0.0000 & 0.00 & 0.00000 & \\
\hline VH2 & 10.0000 & $4.0000-c$ & 0.000105000 & & & \\
\hline Fe-ant & hophyllite SI & $\mathrm{I}(8) \mathrm{FE}(7) \mathrm{O}(2$ & 4) $\mathrm{H}(2)$ fanth & $7 \mathrm{nh}$ & & \\
\hline ST & $\begin{array}{lll}0.0 & -962\end{array}$ & 27230.000 & 725.0000 & 27.8700 & & \\
\hline $\mathrm{C} 3$ & 1383.10000 & 0.0306690 & -4224700.0 & -11257.600 & & 0.00 \\
\hline VHP & 0.000050000 & 700.0 & 0.0000 & $0.00 \quad 0$ & 0.00000 & \\
\hline VH2 & 10.0000 & $4.0000-0$ & 0.000105000 & & & \\
\hline cummi & ngtonite $\quad$ SI & $\mathrm{I}(8) \mathrm{MG}(7) \mathrm{O}(2$ & $(24) \mathrm{H}(2) \quad$ cum & $2 \mathrm{nh}$ & & \\
\hline ST & $0.0-1205$ & 57480.000 & 540.0000 & 26.3300 & & \\
\hline $\mathrm{C} 3$ & 1277.30000 & 0.0258250 & -9704600.0 & -9074.700 & & 0.00 \\
\hline VHP & 0.000050000 & 700.0 & 0.0000 & 0.00 & 0.00000 & \\
\hline VH2 & 10.0000 & $4.0000-0$ & 0.000105000 & & & \\
\hline gruner & $\mathrm{SI}(8)$ & $\mathrm{FE}(7) \mathrm{O}(24) \mathrm{H}$ & I(2) grun & $7 \mathrm{nh}$ & & \\
\hline ST & $0.0 \quad-961$ & 3200.000 & 730.0000 & 27.8400 & & \\
\hline C3 & 1383.10000 & 0.0306690 & -4224700.0 & -11257.600 & & 0.00 \\
\hline VHP & 0.000050000 & 648.0 & 0.0000 & $0.00 \quad 0$ & 0.00000 & \\
\hline VH2 & 10.0000 & $4.0000-0$ & 0.000097200 & & & \\
\hline gedrite & SI $(6) A$ & $\mathrm{AL}(4) \mathrm{MG}(5) \mathrm{O}$ & $\mathrm{O}(24) \mathrm{H}(2) \quad \mathrm{ge}$ & $5 \mathrm{nh}$ & & \\
\hline ST & $0.0-1231$ & 19430.000 & 515.0000 & 25.8000 & & \\
\hline $\mathrm{C} 3$ & 1307.70000 & 0.0236420 & -9307400.0 & -9799.000 & & 0.00 \\
\hline VHP & 0.000048000 & 770.0 & 0.0000 & $0.00 \quad 0$ & 0.00000 & \\
\hline VH2 & 10.0000 & $4.0000-0$ & 0.000115500 & & & \\
\hline sapphi & rine_351 SI & (1) AL(10)MC & $\mathrm{G}(3) \mathrm{O}(20) \quad \mathrm{sp}$ & $4 \mathrm{nh}$ & & \\
\hline ST & $0.0-1113$ & 38460.000 & 420.0000 & 19.7510 & & \\
\hline $\mathrm{C} 3$ & 1175.50000 & -0.0254160 & -7508000.0 & -9336.400 & & 0.00 \\
\hline VHP & 0.000049000 & 1200.0 & 0.0000 & 0.00 & 0.00000 & \\
\hline VH2 & 10.0000 & $4.0000-0$ & 0.000180000 & & & \\
\hline sapphi & rine_221 SI & (2)AL(8)MG & $\mathrm{J}(4) \mathrm{O}(20) \quad \mathrm{spr}$ & $4 \mathrm{nh}$ & & \\
\hline ST & $0.0-1100$ & 03380.000 & 450.0000 & 19.9050 & & \\
\hline $\mathrm{C} 3$ & 1160.30000 & -0.0243240 & -7706600.0 & -8974.200 & & 0.00 \\
\hline VHP & 0.000049000 & 1200.0 & 0.0000 & 0.00 & 0.00000 & \\
\hline VH2 & 10.0000 & $4.0000-0$ & 0.000180000 & & & \\
\hline Fe-sap & ph_221 SI & (2) $\mathrm{AL}(8) \mathrm{FE}($ & (4) $\mathrm{O}(20)$ fspr & $4 \mathrm{nh}$ & & \\
\hline ST & $\begin{array}{ll}0.0 & -958\end{array}$ & 4630.000 & 552.0000 & 19.9230 & & \\
\hline C3 & 1132.90000 & -0.0073480 & -10420200.0 & -7036.600 & & 0.00 \\
\hline VHP & 0.000049000 & 1200.0 & 0.0000 & 0.00 & 0.00000 & \\
\hline VH2 & 10.0000 & $4.0000-0$ & 0.000180000 & & & \\
\hline sapphir & rine_221 SI & (2) $\mathrm{AL}(8) \mathrm{MG}$ & $\mathrm{J}(4) \mathrm{O}(20) \mathrm{spr}$ & $4 \quad 4 \mathrm{nh}$ & & \\
\hline ST & $0.0-1101$ & 19620.000 & 443.0000 & 19.9050 & & \\
\hline $\mathrm{C} 3$ & 1160.30000 & -0.0243240 & -7706600.0 & -8974.200 & & 0.00 \\
\hline VHP & 0.000049000 & 1200.0 & 0.0000 & 0.00 & 0.00000 & \\
\hline VH2 & 10.0000 & $4.0000-0$ & 0.000180000 & & & \\
\hline sapphir & rine_793 SI & (1.5)AL(9)M & $\mathrm{IG}(3.5) \mathrm{O}(20)$ & spr7 & $\mathrm{nh}$ & \\
\hline ST & $0.0-1106$ & 55630.000 & 448.0000 & 19.7750 & & \\
\hline C3 & 1167.90000 & -0.0248700 & -7607300.0 & -9155.300 & & 0.00 \\
\hline VHP & 0.000049000 & 1200.0 & 0.0000 & 0.00 & 0.00000 & \\
\hline VH2 & 10.0000 & $4.0000-0$ & 0.000180000 & & & \\
\hline
\end{tabular}




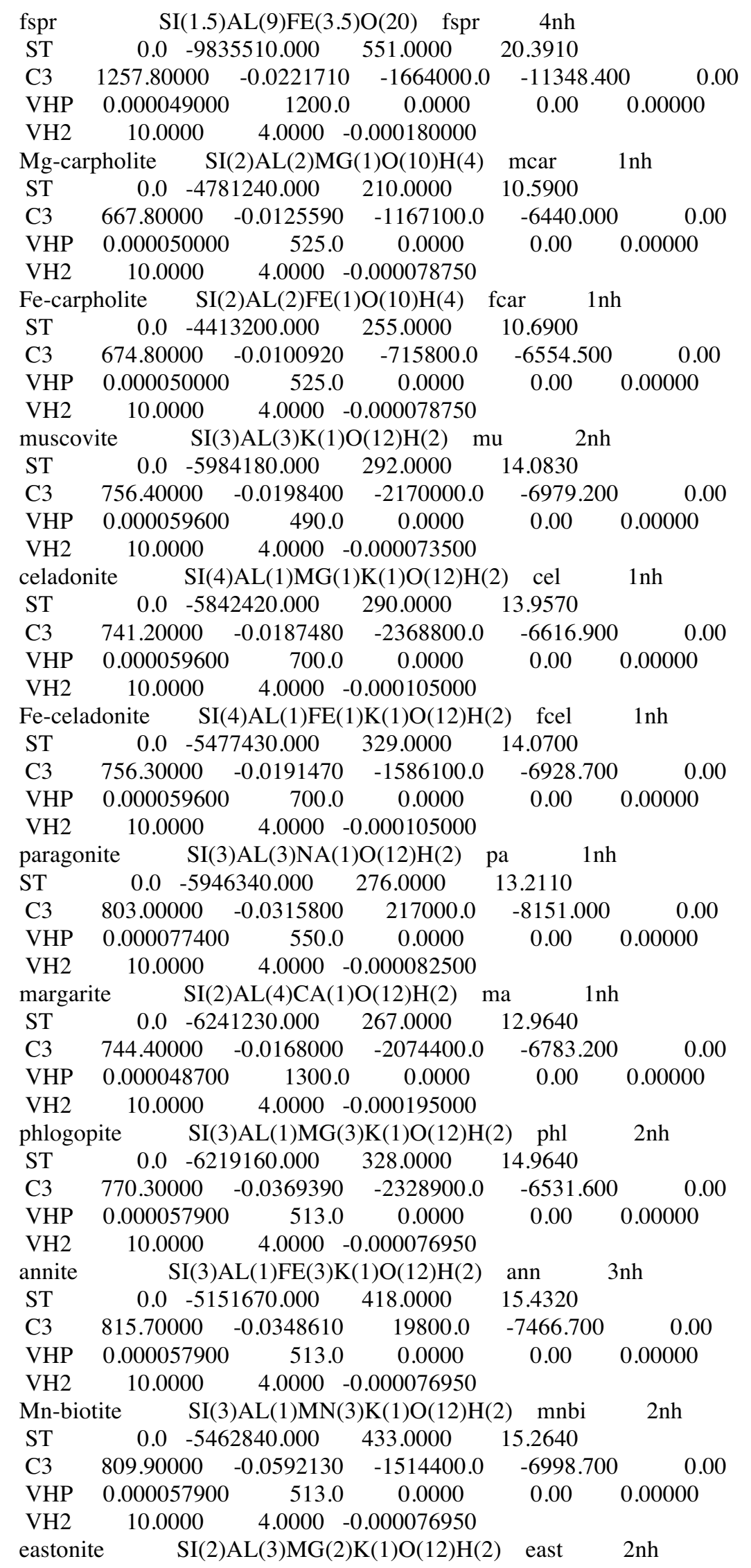




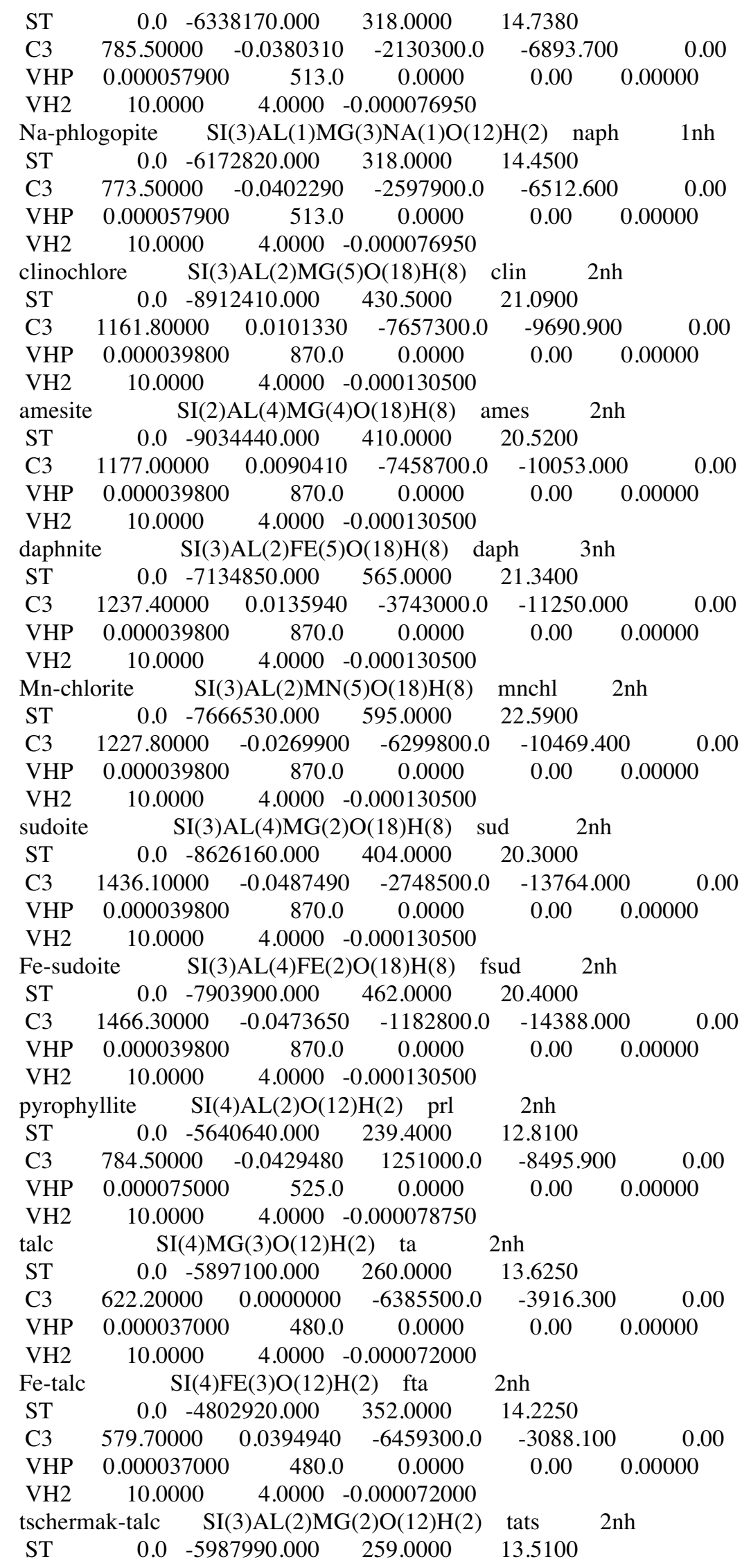




\begin{tabular}{|c|c|c|c|c|c|}
\hline C3 & 549.50000 & 0.0363240 & -8606600.0 & -2515.300 & 0.00 \\
\hline VHP & 0.000037000 & 480.0 & 0.0000 & 0.00 & 0.00000 \\
\hline VH2 & 10.0000 & 4.0000 & -0.000072000 & & \\
\hline kaolinite & $\mathrm{SI}(2) \mathrm{A}$ & $\mathrm{AL}(2) \mathrm{O}(9) \mathrm{H}$ & I(4) kao & $2 \mathrm{nh}$ & \\
\hline ST & $0.0-4122$ & 2180.000 & 203.7000 & 9.9340 & \\
\hline $\mathrm{C} 3$ & 436.70000 & -0.0342950 & -4055900.0 & -2699.100 & 0.00 \\
\hline VHP & 0.000051000 & 645.0 & 0.0000 & 0.00 & 0.00000 \\
\hline VH2 & 10.0000 & 4.0000 & -0.000096750 & & \\
\hline prehnite & SI(3)A & $\mathrm{AL}(2) \mathrm{CA}(2)$ & $\mathrm{O}(12) \mathrm{H}(2) \quad \mathrm{pr}$ & $1 \mathrm{nh}$ & \\
\hline ST & $0.0-6203$ & 3180.000 & 292.8000 & 14.0260 & \\
\hline C3 & 724.90000 & -0.0138650 & -2059000.0 & -6323.900 & 0.00 \\
\hline VHP & 0.000051000 & 835.0 & 0.0000 & 0.00 & 0.00000 \\
\hline $\mathrm{VH} 2$ & 10.0000 & 4.0000 & -0.000125250 & & \\
\hline chrysotils & le $\quad \mathrm{SI}(2) \Lambda$ & $\mathrm{MG}(3) \mathrm{O}(9) \mathrm{H}$ & $\mathrm{H}(4) \quad \mathrm{chr}$ & $3 \mathrm{nh}$ & \\
\hline ST & $\begin{array}{ll}0.0 & -4359\end{array}$ & 9030.000 & 221.3000 & 10.7460 & \\
\hline $\mathrm{C} 3$ & 624.70000 & -0.0207700 & -1721800.0 & -5619.400 & 0.00 \\
\hline VHP & 0.000047000 & 525.0 & 0.0000 & 0.00 & 0.00000 \\
\hline VH2 & 10.0000 & 4.0000 & -0.000078750 & & \\
\hline antigorite & SI(34) & ) $\mathrm{MG}(48) \mathrm{O}(1$ & 147) $\mathrm{H}(62) \quad$ atg & g $\quad 48 \mathrm{nh}$ & \\
\hline ST & $\begin{array}{lll}0.0 & -7142\end{array}$ & 24310.000 & 3591.0000 & 175.4800 & \\
\hline $\mathrm{C} 3$ & 9621.00000 & -0.0911830 & -35941600.0 & $0 \quad-83034.20$ & 0.0 \\
\hline VHP & 0.000047000 & 525.0 & 0.0000 & 0.00 & 0.00000 \\
\hline VH2 & 10.0000 & 4.0000 & -0.000078750 & & \\
\hline high-albi & ite $\quad \operatorname{SI}(3)$ & )AL(1)NA(1 & 1)O(8) abh & $1 \mathrm{nh}$ & \\
\hline ST & -3924 & 4800.000 & 223.4000 & 10.1090 & \\
\hline $\mathrm{C} 3$ & 452.00000 & -0.0133640 & -1275900.0 & -3953.600 & 0.00 \\
\hline VHP & 0.000045600 & 593.0 & 0.0000 & 0.00 & 0.00000 \\
\hline VH2 & 10.0000 & 4.0000 & -0.000088950 & & \\
\hline microclin & ine $\quad$ SI(3) & $\operatorname{AL}(1) \mathrm{K}(1)$ & $\mathrm{O}(8)$ mic & $1 \mathrm{nh}$ & \\
\hline ST & $0.0-3975$ & 5110.000 & 216.0000 & 10.8920 & \\
\hline $\mathrm{C} 3$ & 448.80000 & -0.0100750 & -1007300.0 & -3973.100 & 0.00 \\
\hline VHP & 0.000033500 & 574.0 & 0.0000 & 0.00 & 0.00000 \\
\hline VH2 & 10.0000 & 4.0000 & -0.000086100 & & \\
\hline sanidine & $\mathrm{SI}(3) A$ & $\mathrm{AL}(1) \mathrm{K}(1) \mathrm{O}$ & (8) san & $1 \mathrm{nh}$ & \\
\hline ST & $0.0-3964$ & 4960.000 & 230.0000 & 10.9000 & \\
\hline C3 & 448.80000 & -0.0100750 & -1007300.0 & -3973.100 & $0 \quad 0.00$ \\
\hline VHP & 0.000033500 & 574.0 & 0.0000 & 0.00 & 0.00000 \\
\hline VH2 & 10.0000 & 4.0000 & -0.000086100 & & \\
\hline anorthite & SI (2)A & $\mathrm{AL}(2) \mathrm{CA}(1)$ & $\mathrm{O}(8)$ an & $+1 \mathrm{nh}$ & \\
\hline ST & $0.0-4233$ & 3480.000 & 200.0000 & 10.0790 & \\
\hline C3 & 371.60000 & 0.0126150 & -4110200.0 & -2038.400 & 0.00 \\
\hline VHP & 0.000023800 & 919.0 & 2300.0000 & 11.00 & 0.05000 \\
\hline VH2 & 10.0000 & 4.0000 & -0.000137850 & & \\
\hline quartz & $\mathrm{SI}(1) \mathrm{O}$ & (2) $\quad \mathrm{q}$ & $1 \mathrm{nh}$ & & \\
\hline ST & $0.0 \quad-910$ & 0830.000 & 41.5000 & 2.2688 & \\
\hline $\mathrm{C} 3$ & 110.70000 & -0.0051890 & 0.0 & -1128.300 & 0.00 \\
\hline VHP & 0.000006500 & 750.0 & 847.0000 & 4.95 & 0.11880 \\
\hline VH2 & 10.0000 & 4.0000 & -0.000112500 & & \\
\hline tridymite & $\mathrm{SI}(1) \mathrm{C}$ & $\mathrm{O}(2) \operatorname{trd}$ & $1 \mathrm{nh}$ & & \\
\hline ST & $0.0 \quad-906$ & 6690.000 & 46.1000 & 2.7000 & \\
\hline $\mathrm{C} 3$ & $97.90000-1$ & -0.0033500 & -636200.0 & -774.000 & 0.00 \\
\hline VHP & 0.000005000 & 750.0 & 0.0000 & 0.00 & 0.00000 \\
\hline VH2 & 10.0000 & 4.0000 & -0.000112500 & & \\
\hline cristobali & lite $\quad \mathrm{SI}(1) \mathrm{C}$ & $\mathrm{O}(2)$ crst & $1 \mathrm{nh}$ & & \\
\hline ST & $0.0-905$ & 5990.000 & 46.5000 & 2.6100 & \\
\hline $\mathrm{C} 3$ & $97.90000-1$ & -0.0033500 & -636200.0 & -774.000 & 0.00 \\
\hline
\end{tabular}




\begin{tabular}{|c|c|c|c|c|c|}
\hline VHP & 0.000008100 & 600.0 & 0.0000 & 0.00 & 0.00000 \\
\hline VH2 & 10.0000 & $4.0000-$ & -0.000090000 & & \\
\hline coesite & $\mathrm{SI}(1) \mathrm{O}$ & (2) coe & $1 \mathrm{nh}$ & & \\
\hline ST & $0.0 \quad-905$ & 5470.000 & 40.8000 & 2.0640 & \\
\hline C3 & $96.50000-1$ & -0.0005770 & -444800.0 & -798.200 & 0.00 \\
\hline VHP & 0.000018000 & 1000.0 & 0.0000 & 0.00 & 0.00000 \\
\hline VH2 & 10.0000 & $4.0000-$ & -0.000150000 & & \\
\hline stishovit & $\mathrm{SI}(1) \mathrm{C}$ & $\mathrm{O}(2) \quad$ stv & $1 \mathrm{nh}$ & & \\
\hline ST & $0.0 \quad-875$ & 5630.000 & 24.5000 & 1.4014 & \\
\hline C3 & 68.10000 & 0.0060100 & -1978200.0 & -82.100 & 0.00 \\
\hline VHP & 0.000025000 & 3160.0 & $\begin{array}{l}0 \\
0.0000\end{array}$ & 0.00 & 0.00000 \\
\hline VH2 & 10.0000 & $4.0000-$ & -0.000474000 & & \\
\hline nephelin & ne $\quad$ SI $(1)$ & $\mathrm{AL}(1) \mathrm{NA}(1$ & 1) $\mathrm{O}(4)$ ne & $1 \mathrm{nh}$ & \\
\hline ST & $0.0-2095$ & 5080.000 & 124.4000 & 5.4190 & \\
\hline C3 & 272.70000 & -0.0123980 & 0.0 & -2763.100 & 0.00 \\
\hline VHP & 0.000081000 & 600.0 & 467.0000 & 10.00 & 0.08000 \\
\hline VH2 & 10.0000 & $4.0000-$ & -0.000090000 & & \\
\hline kalsilite & $\mathrm{SI}(1) \mathrm{A}$ & $\mathrm{L}(1) \mathrm{K}(1) \mathrm{O}($ & (4) kals & $1 \mathrm{nh}$ & \\
\hline ST & $0.0-2121$ & 1920.000 & 134.0000 & 6.0400 & \\
\hline $\mathrm{C} 3$ & 242.00000 & -0.0044820 & -895800.0 & -1935.800 & 0.00 \\
\hline VHP & 0.000057600 & 590.0 & 0.0000 & 0.00 & 0.00000 \\
\hline $\mathrm{VH} 2$ & 10.0000 & 4.0000 & -0.000088500 & & \\
\hline leucite & $\mathrm{SI}(2) \mathrm{A}$ & $\mathrm{L}(1) \mathrm{K}(1) \mathrm{O}($ & (6) lc 1 & $1 \mathrm{nh}$ & \\
\hline ST & $\begin{array}{ll}0.0 & -3029\end{array}$ & 9160.000 & 200.0000 & 8.8280 & \\
\hline C3 & 369.80000 & -0.0163320 & 684700.0 & -3683.100 & 0.00 \\
\hline VHP & 0.000036700 & 630.0 & 938.0000 & 18.00 & 0.48200 \\
\hline VH2 & 10.0000 & $4.0000-$ & -0.000094500 & & \\
\hline meionite & $\mathrm{SI}(6)$ & $\mathrm{AL}(6) \mathrm{CA}(4)$ & t) $\mathrm{O}(27) \mathrm{C}(1) \mathrm{m}$ & me $\quad 4 \mathrm{nh}$ & \\
\hline ST & $0.0-1384$ & 43570.000 & 752.0000 & 33.9850 & \\
\hline C3 & 1359.00000 & 0.0364420 & -8594700.0 & $\quad-9598.200$ & 0.00 \\
\hline VHP & 0.000031600 & 870.0 & 0.0000 & 0.00 & 0.00000 \\
\hline VH2 & 10.0000 & $4.0000-$ & -0.000130500 & & \\
\hline wairakite & $\mathrm{SI}(4)$ & $\operatorname{AL}(2) \mathrm{CA}(1)$ & $\mathrm{O}(14) \mathrm{H}(4) \quad \mathrm{w}$ & wrk $\quad 1$ nh & \\
\hline ST & $0.0-6666$ & 6420.000 & 375.0000 & 19.0400 & \\
\hline $\mathrm{C} 3$ & 838.30000 & -0.0214600 & -2272000.0 & -7292.300 & 0.00 \\
\hline VHP & 0.000023800 & 1000.0 & $0 \quad 0.0000$ & 0.00 & 0.00000 \\
\hline VH2 & 10.0000 & $4.0000-$ & -0.000150000 & & \\
\hline laumonti & tite $\quad \mathrm{SI}(4)$ & ) $\operatorname{AL}(2) \mathrm{CA}(1$ & 1) $\mathrm{O}(16) \mathrm{H}(8)$ & $1 \mathrm{nh}$ & \\
\hline ST & $\begin{array}{ll}0.0 & -7268\end{array}$ & 8470.000 & 457.0000 & 20.3700 & \\
\hline C3 & 1013.40000 & -0.0214130 & $\begin{array}{ll}0 & -2235800.0\end{array}$ & $0 \quad-8806.700$ & 0.00 \\
\hline VHP & 0.000023800 & 1000.0 & 0.0000 & 0.00 & 0.00000 \\
\hline VH2 & 10.0000 & 4.0000 & -0.000150000 & & \\
\hline heulandi & lite $\quad S I(7)$ & $\mathrm{AL}(2) \mathrm{CA}(1$ & 1)O(24)H(12) & heu & \\
\hline ST & $0.0-1059$ & 99140.000 & 669.0000 & 31.8000 & \\
\hline $\mathrm{C} 3$ & 1504.80000 & -0.0332240 & -2959300.0 & -13297.200 & 0.00 \\
\hline VHP & 0.000023800 & 1000.0 & 0.0000 & 0.00 & 0.00000 \\
\hline VH2 & 10.0000 & $4.0000-$ & -0.000150000 & & \\
\hline stilbite & SI(7)AI & $\mathrm{L}(2) \mathrm{CA}(1) \mathrm{O}$ & $(25) \mathrm{H}(14) \quad$ stl & $1 \mathrm{nh}$ & \\
\hline ST & $0.0-1089$ & 98830.000 & 710.0000 & 32.8700 & \\
\hline C3 & 1588.40000 & -0.0320430 & o -3071600.0 & -13966.900 & 0.00 \\
\hline VHP & 0.000023800 & 1000.0 & 0.0000 & 0.00 & 0.00000 \\
\hline VH2 & 10.0000 & 4.0000 & -0.000150000 & & \\
\hline analcite & SI(2)A & $\mathrm{AL}(1) \mathrm{NA}(1) \mathrm{C}$ & $\mathrm{O}(7) \mathrm{H}(2)$ anl & $1 \quad 1 \mathrm{nh}$ & \\
\hline ST & $\begin{array}{ll}0.0 & -3309\end{array}$ & 9900.000 & 232.0000 & 9.7400 & \\
\hline C3 & 643.50000 & -0.0160670 & 9302300.0 & -9179.600 & 0.00 \\
\hline VHP & 0.000050000 & 400.0 & 0.0000 & 0.00 & 0.00000 \\
\hline
\end{tabular}




\begin{tabular}{|c|c|c|c|c|c|}
\hline VH2 & 10.0000 & $4.0000-$ & -0.000060000 & & \\
\hline lime & $\mathrm{CA}(1) \mathrm{C}$ & $\mathrm{O}(1)$ lime & $1 \mathrm{nh}$ & & \\
\hline $\mathrm{ST}$ & $0.0-634$ & 4950.000 & 38.1000 & 1.6764 & \\
\hline $\mathrm{C} 3$ & 52.40000 & 0.0036730 & -750700.0 & -51.000 & 0.00 \\
\hline VHP & 0.000066500 & 1160.0 & 0.0000 & 0.00 & 0.00000 \\
\hline VH2 & 10.0000 & $4.0000-$ & -0.000174000 & & \\
\hline rutile & $\mathrm{TI}(1) \mathrm{O}$ & (2) $\mathrm{ru}$ & $\operatorname{lnh}$ & & \\
\hline $\mathrm{ST}$ & $0.0 \quad-944$ & 4180.000 & 50.6000 & 1.8820 & \\
\hline $\mathrm{C} 3$ & 90.40000 & 0.0029000 & 0.0 & -623.800 & 0.00 \\
\hline VHP & 0.000044300 & 2225.0 & 0.0000 & 0.00 & 0.00000 \\
\hline VH2 & 10.0000 & $4.0000-$ & -0.000333750 & & \\
\hline periclas & MG(1 & 1)O(1) per & $1 \mathrm{nh}$ & & \\
\hline ST & $0.0-601$ & 1600.000 & 26.9000 & 1.1250 & \\
\hline $\mathrm{C} 3$ & 60.50000 & 0.0003620 & -535800.0 & -299.200 & 0.00 \\
\hline VHP & 0.000062000 & 1650.0 & 0.0000 & 0.00 & 0.00000 \\
\hline VH2 & 10.0000 & $4.0000-$ & -0.000247500 & & \\
\hline mangan & osite MN & $\mathrm{N}(1) \mathrm{O}(1) \quad \mathrm{m}$ & nang $\quad 1 \mathrm{nh}$ & & \\
\hline $\mathrm{ST}$ & -385 & 5150.000 & 59.7000 & 1.3221 & \\
\hline C3 & 59.80000 & 0.0036000 & -31400.0 & -282.600 & 0.00 \\
\hline VHP & 0.000063000 & 1640.0 & 0.0000 & 0.00 & 0.00000 \\
\hline VH2 & 10.0000 & 4.0000 & -0.000246000 & & \\
\hline corundu & $\mathrm{Im} \quad \mathrm{AL}$ & $(2) \mathrm{O}(3)$ cor & $\mathrm{r} \quad 2 \mathrm{nh}$ & & \\
\hline ST & $0.0-167$ & 5250.000 & 50.9000 & 2.5580 & \\
\hline $\mathrm{C} 3$ & 139.50000 & 0.0058900 & -2460600.0 & -589.200 & 0.00 \\
\hline VHP & 0.000041900 & 2520.0 & 0.0000 & 0.00 & 0.00000 \\
\hline VH2 & 10.0000 & $4.0000-$ & -0.000378000 & & \\
\hline hematit & $\mathrm{FE}(2)$ & $\mathrm{O}(3)$ hem & $2 \mathrm{nh}$ & & \\
\hline ST & $\begin{array}{ll}0.0 & -825\end{array}$ & 5710.000 & 87.4000 & 3.0274 & \\
\hline C3 & 163.90000 & 0.0000000 & -2257200.0 & -657.600 & 0.00 \\
\hline VHP & 0.000059900 & 1996.0 & 955.0000 & 15.60 & 0.00000 \\
\hline VH2 & 10.0000 & $4.0000-$ & -0.000299400 & & \\
\hline pyropha & anite $\quad \mathrm{TI}(1$ & 1) $\mathrm{MN}(1) \mathrm{O}(3)$ & ) pnt 1 & $\operatorname{lnh}$ & \\
\hline ST & $0.0-135$ & 9240.000 & 104.9000 & 3.2880 & \\
\hline $\mathrm{C} 3$ & 141.90000 & 0.0033730 & -1940700.0 & -407.600 & 0.00 \\
\hline VHP & 0.000049500 & 1770.0 & 0.0000 & 0.00 & 0.00000 \\
\hline VH2 & 10.0000 & $4.0000-$ & -0.000265500 & & \\
\hline geikieli & $\mathrm{TI}(1) \Gamma$ & $\mathrm{MG}(1) \mathrm{O}(3)$ & geik $\quad 1 n$ & $\mathrm{hh}$ & \\
\hline ST & $0.0-156^{\prime}$ & 7490.000 & 74.6000 & 3.0860 & \\
\hline C3 & 151.00000 & 0.0000000 & -1890400.0 & -652.200 & 0.00 \\
\hline VHP & 0.000049500 & 1770.0 & 0.0000 & 0.00 & 0.00000 \\
\hline VH2 & 10.0000 & $4.0000-$ & -0.000265500 & & \\
\hline ilmenite & $\mathrm{TI}(1) \mathrm{H}$ & $\mathrm{FE}(1) \mathrm{O}(3)$ & ilm $\quad 1 n h$ & & \\
\hline ST & $0.0-123$ & 1300.000 & 108.9000 & 3.1690 & \\
\hline $\mathrm{C} 3$ & 138.90000 & 0.0050810 & -1288800.0 & -463.700 & 0.00 \\
\hline VHP & 0.000049500 & 1770.0 & 1900.0000 & 11.00 & 0.02000 \\
\hline VH2 & 10.0000 & 4.0000 & 0.000265500 & & \\
\hline baddele & yite $\quad \mathrm{O}(2)$ & $\mathrm{ZR}(1) \quad b d y$ & $y \quad \operatorname{lnh}$ & & \\
\hline $\mathrm{ST}$ & $0.0-110$ & 1030.000 & 50.4000 & 2.1150 & \\
\hline $\mathrm{C} 3$ & 90.70000 & 0.0000000 & -813300.0 & -438.800 & 0.00 \\
\hline VHP & 0.000037600 & 2225.0 & 0.0000 & 0.00 & 0.00000 \\
\hline VH2 & 10.0000 & $4.0000-$ & 0.000333750 & & \\
\hline spinel & $\mathrm{AL}(2) \mathrm{I}$ & $\mathrm{MG}(1) \mathrm{O}(4)$ & $\mathrm{sp} \quad \operatorname{lnh}$ & & \\
\hline $\mathrm{ST}$ & $0.0-230$ & 0720.000 & 81.5000 & 3.9780 & \\
\hline $\mathrm{C} 3$ & 242.70000 & -0.0060370 & -2315100.0 & -1678.100 & 0.00 \\
\hline VHP & 0.000043100 & 1945.0 & 0.0000 & 0.00 & 0.00000 \\
\hline VH2 & 10.0000 & $4.0000-$ & -0.000291750 & & \\
\hline
\end{tabular}




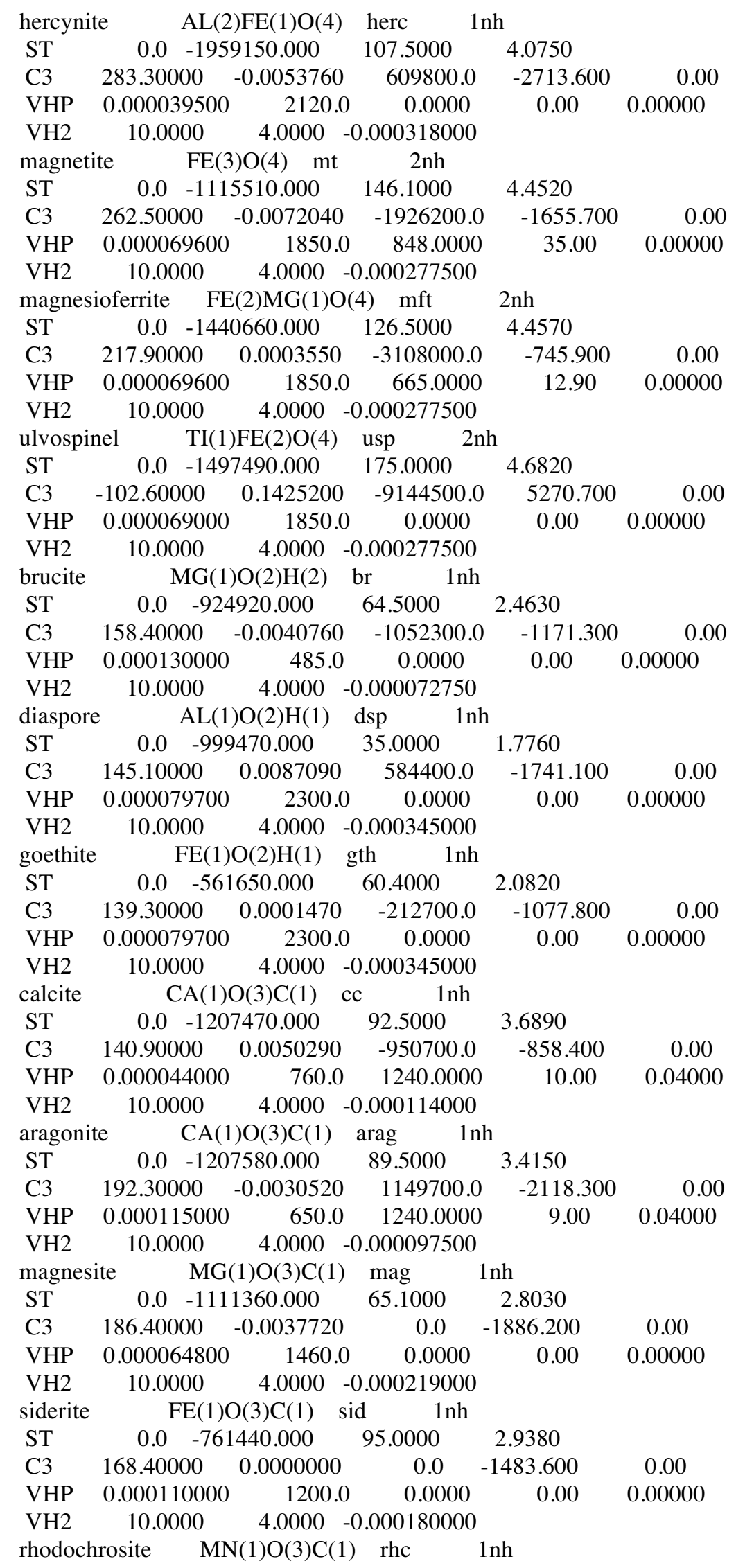




\begin{tabular}{|c|c|c|c|c|}
\hline ST & $0.0 \quad-891090.000$ & 98.0000 & 3.1070 & \\
\hline $\mathrm{C} 3$ & $169.50000 \quad 0.0000000$ & 0.0 & -1534.300 & 0.00 \\
\hline VHP & $0.000065000 \quad 800.0$ & 0.0000 & 0.00 & 0.00000 \\
\hline VH2 & 10.0000 & -0.000120000 & & \\
\hline dolomite & $\mathrm{MG}(1) \mathrm{CA}(1) \mathrm{O}(6$ & 6)C(2) dol & $1 \mathrm{nh}$ & \\
\hline ST & $0.0-2324430.000$ & 156.0000 & 6.4340 & \\
\hline $\mathrm{C} 3$ & $358.90000 \quad-0.0049050$ & 0.0 & -3456.200 & 0.00 \\
\hline VHP & $0.000063500 \quad 900.0$ & 1373.0000 & 13.00 & 0.01500 \\
\hline VH2 & 10.0000 & -0.000135000 & & \\
\hline ankerite & $\mathrm{FE}(1) \mathrm{CA}(1) \mathrm{O}(6)$ & $\mathrm{C}(2)$ ank & $1 \mathrm{nh}$ & \\
\hline ST & $0.0-1971270.000$ & 187.0000 & 6.6060 & \\
\hline $\mathrm{C} 3$ & $341.00000 \quad-0.0011610$ & 0.0 & -3054.800 & 0.00 \\
\hline VHP & $0.000063500 \quad 900.0$ & 1273.0000 & $\quad 9.00$ & 0.01000 \\
\hline VH2 & 10.0000 & -0.000135000 & & \\
\hline sylvite & $\mathrm{K}(1) \mathrm{CL}(1)$ syv & $1 \mathrm{nh}$ & & \\
\hline ST & $0.0-436500.000$ & 82.6000 & 3.7520 & \\
\hline $\mathrm{C} 3$ & $46.20000 \quad 0.0179700$ & 0.0 & 0.000 & 0.00 \\
\hline VHP & $0.000247000 \quad 170.0$ & 0.0000 & 0.00 & 0.00000 \\
\hline VH2 & $10.0000 \quad 4.0000$ & -0.000025500 & & \\
\hline halite & NA(1)CL(1) hlt & $1 \mathrm{nh}$ & & \\
\hline ST & $0.0-411300.000$ & 72.1000 & 2.7020 & \\
\hline $\mathrm{C} 3$ & $45.20000 \quad 0.0179700$ & 0.0 & 0.000 & 0.00 \\
\hline VHP & $0.000269000 \quad 240.0$ & 0.0000 & 0.00 & 0.00000 \\
\hline VH2 & 10.0000 & -0.000036000 & & \\
\hline iron & $\mathrm{FE}(1)$ & $\operatorname{lnh}$ & & \\
\hline ST & $\begin{array}{lll}0.0 & 0.000 & 2\end{array}$ & $7.3200 \quad 0$ & .7092 & \\
\hline $\mathrm{C} 3$ & 0.0051580 & 723100.0 & -556.200 & 0.00 \\
\hline VHP & $0.000074600 \quad 1680 .($ & 1042.000 & 8.30 & 0.00000 \\
\hline VH2 & 10.0000 & -0.000252000 & & \\
\hline nickel & $\mathrm{NI}(1)$ & $1 \mathrm{nh}$ & & \\
\hline ST & $\begin{array}{lll}0.0 & 0.000 \quad 2\end{array}$ & 9.8700 & 6588 & \\
\hline $\mathrm{C} 3$ & 0.0000000 & 585900.0 & -533.900 & 0.00 \\
\hline VHP & $0.000088600 \quad 1870 .($ & 631.0000 & 3.00 & 0.00000 \\
\hline VH2 & 10.0000 & -0.000280500 & & \\
\hline graphite & $\mathrm{C}(1) \quad \mathrm{gph}$ & $1 \mathrm{nh}$ & & \\
\hline ST & $0.0 \quad 0.000$ & $5.8500 \quad 0$. & 5298 & \\
\hline $\mathrm{C} 3$ & -0.0044280 & 488600.0 & -805.500 & 0.00 \\
\hline VHP & $0.000048400 \quad 390.0$ & 0.0000 & 0.00 & 0.00000 \\
\hline VH2 & 10.0000 & -0.000058500 & & \\
\hline diamond & $\mathrm{C}(1)$ diam & $1 \mathrm{nh}$ & & \\
\hline ST & $0.0 \quad 2070.000$ & 2.3000 & 0.3417 & \\
\hline $\mathrm{C} 3$ & $24.30000 \quad 0.0062720$ & -377400.0 & -273.400 & 0.00 \\
\hline VHP & $0.000016500 \quad 5800 .($ & $0 \quad 0.0000$ & 0.00 & 0.00000 \\
\hline VH2 & $10.0000 \quad 4.0000$ & -0.000870000 & & \\
\hline \multicolumn{5}{|c|}{$* * * * *$ GAS DATA $* * * * *$} \\
\hline \multicolumn{5}{|c|}{$\begin{array}{l}\text { Water } \\
\text { SPC HHP98 }\end{array}$} \\
\hline ST & $0.0-241810.000$ & 188.8000 & 0.0000 & \\
\hline $\mathrm{C} 3$ & $40.10000 \quad 0.0086560$ & 487500.0 & -251.200 & 0.00 \\
\hline \multicolumn{5}{|c|}{ Carbon-dioxide $\quad \mathrm{C}(1) \mathrm{O}(2) \quad \mathrm{CO} 2 \quad \mathrm{nh}$} \\
\hline SPC C & CHP98 & & & \\
\hline ST & $0.0-393510.000$ & 213.7000 & 0.0000 & \\
\hline $\mathrm{C} 3$ & $87.80000 \quad-0.0026440$ & 706400.0 & -998.900 & 0.00 \\
\hline $\mathrm{CO}$ & $\mathrm{C}(1) \mathrm{O}(1)$ & & use & \\
\hline ST & $0.0-110530.000$ & 197.6700 & 0.0000 & \\
\hline C3 & $45.70000 \quad-0.0000970$ & 662700.0 & -414.700 & 0.00 \\
\hline
\end{tabular}




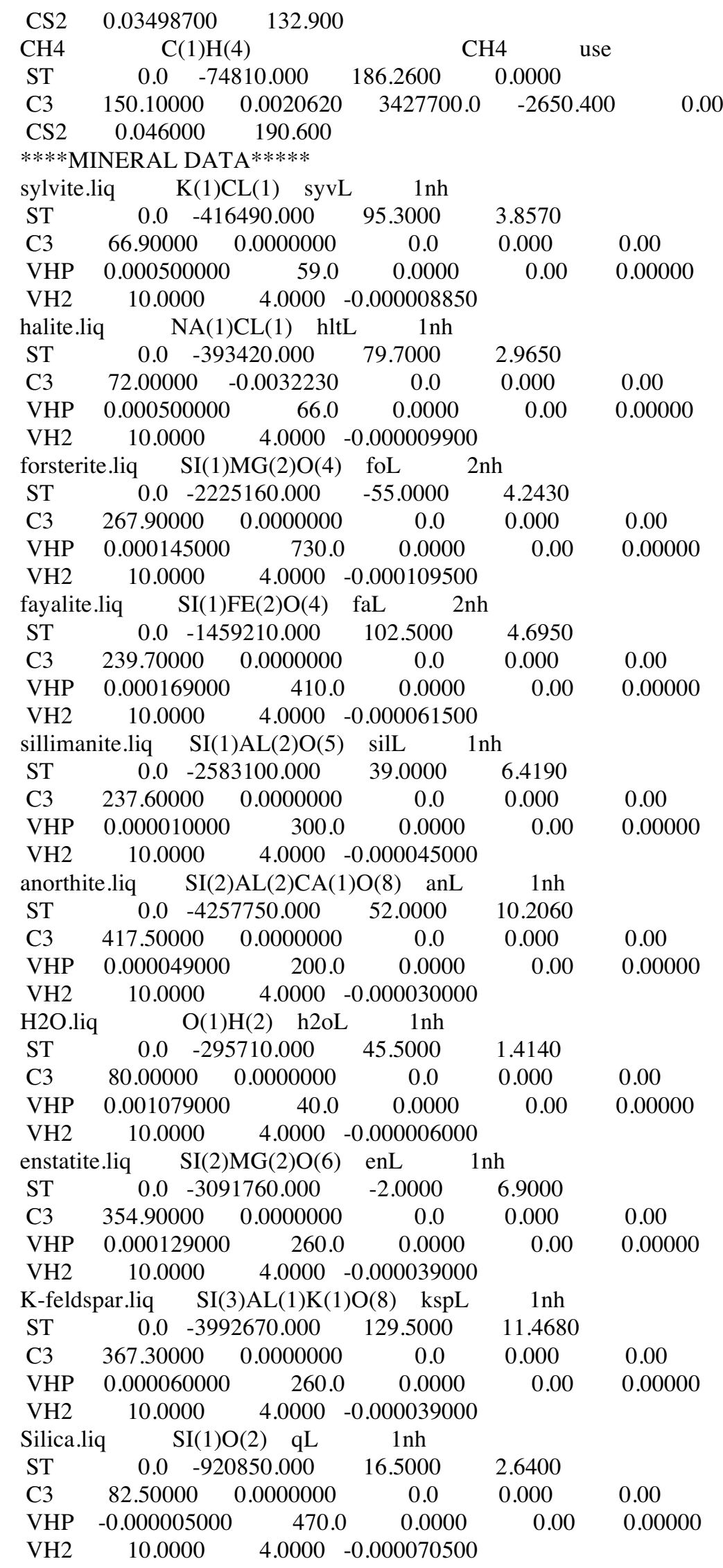




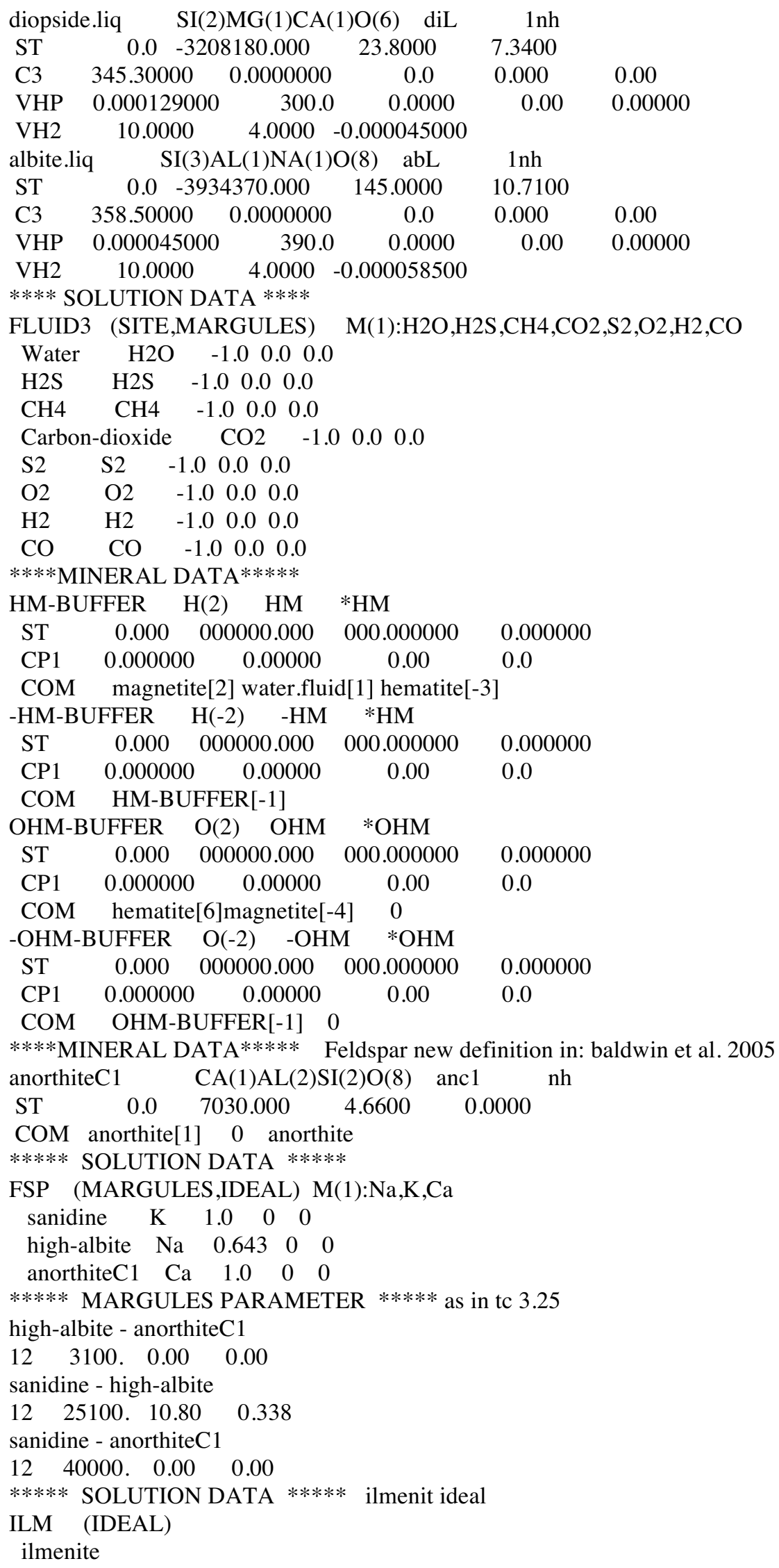




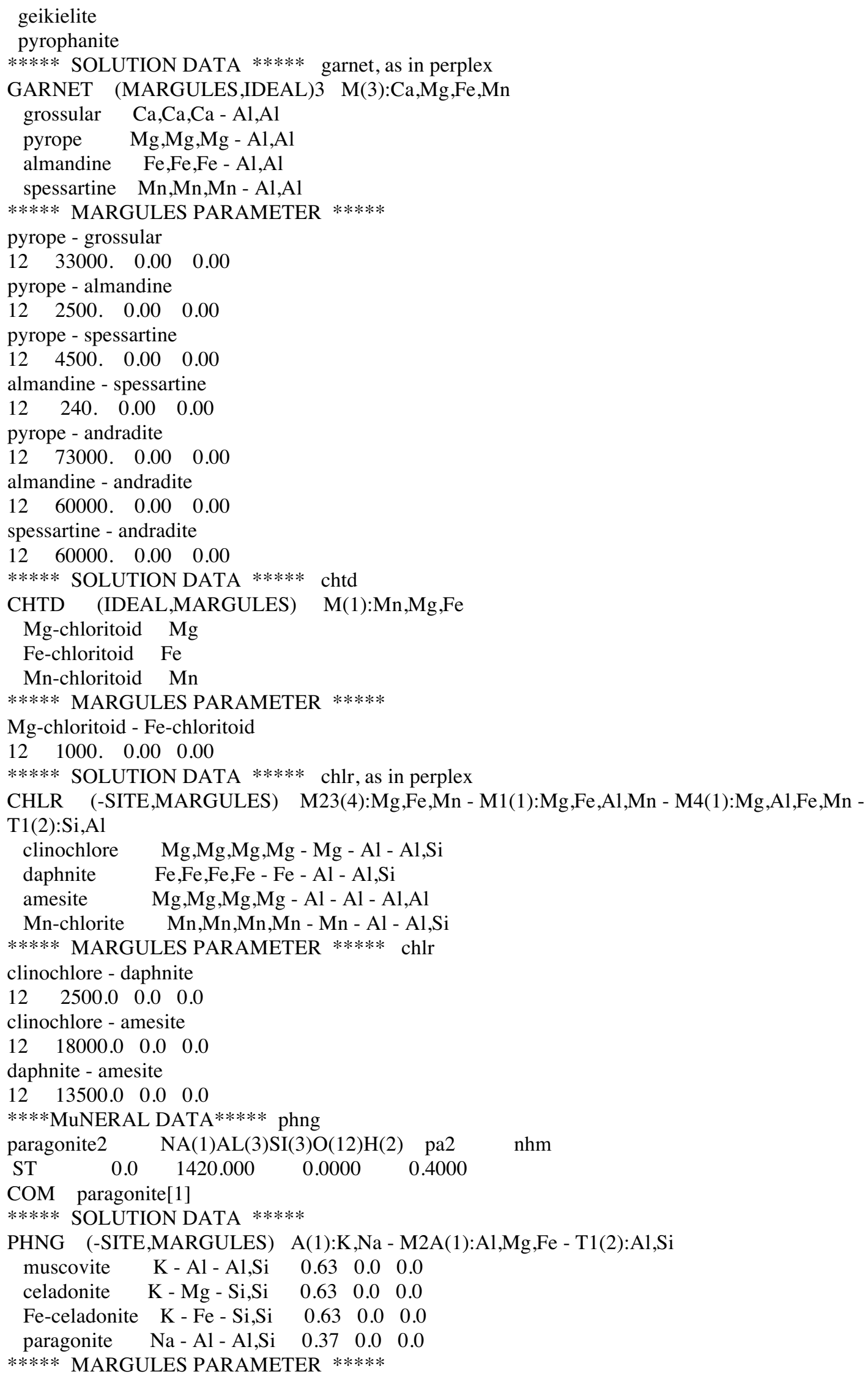




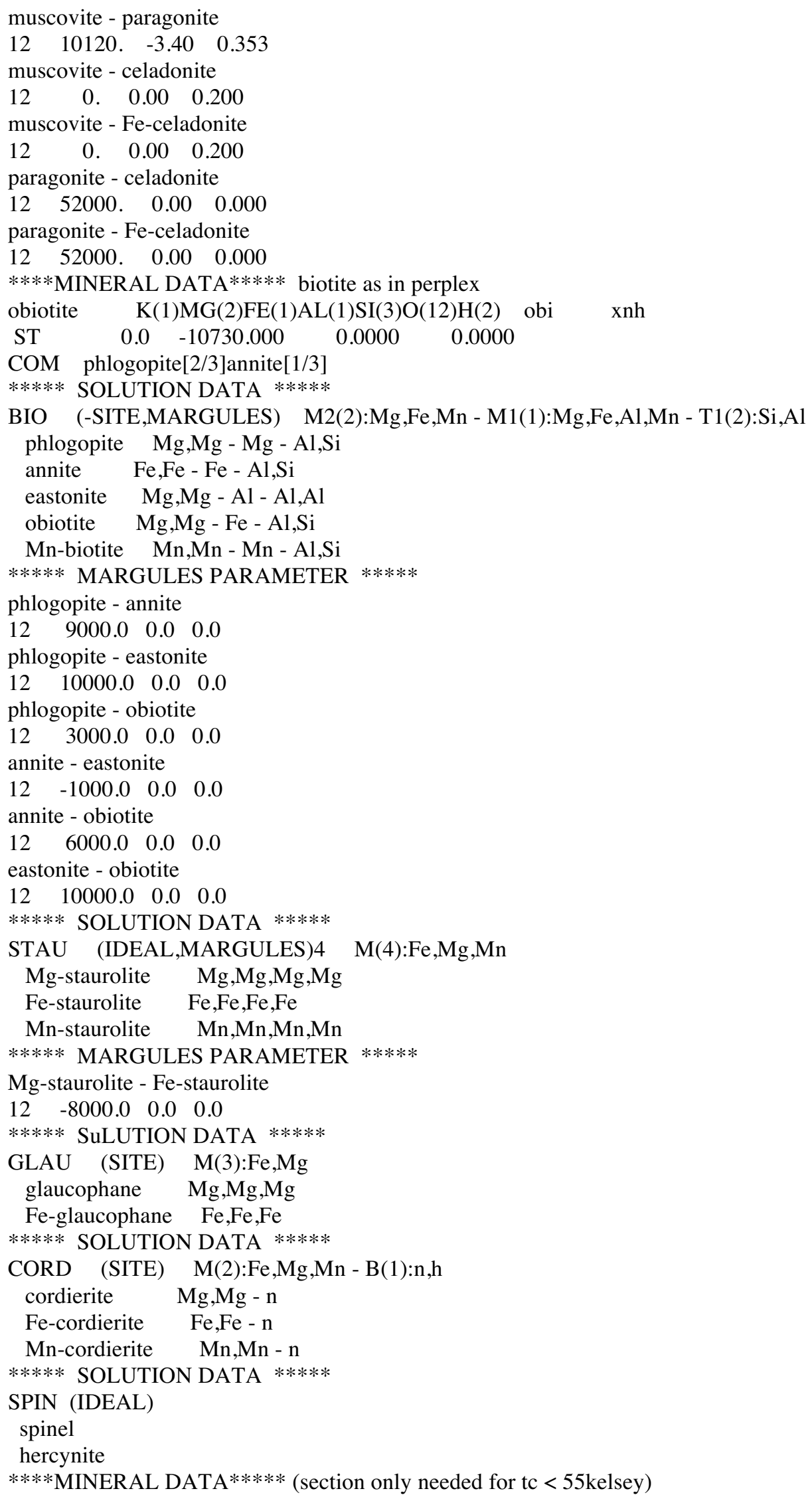




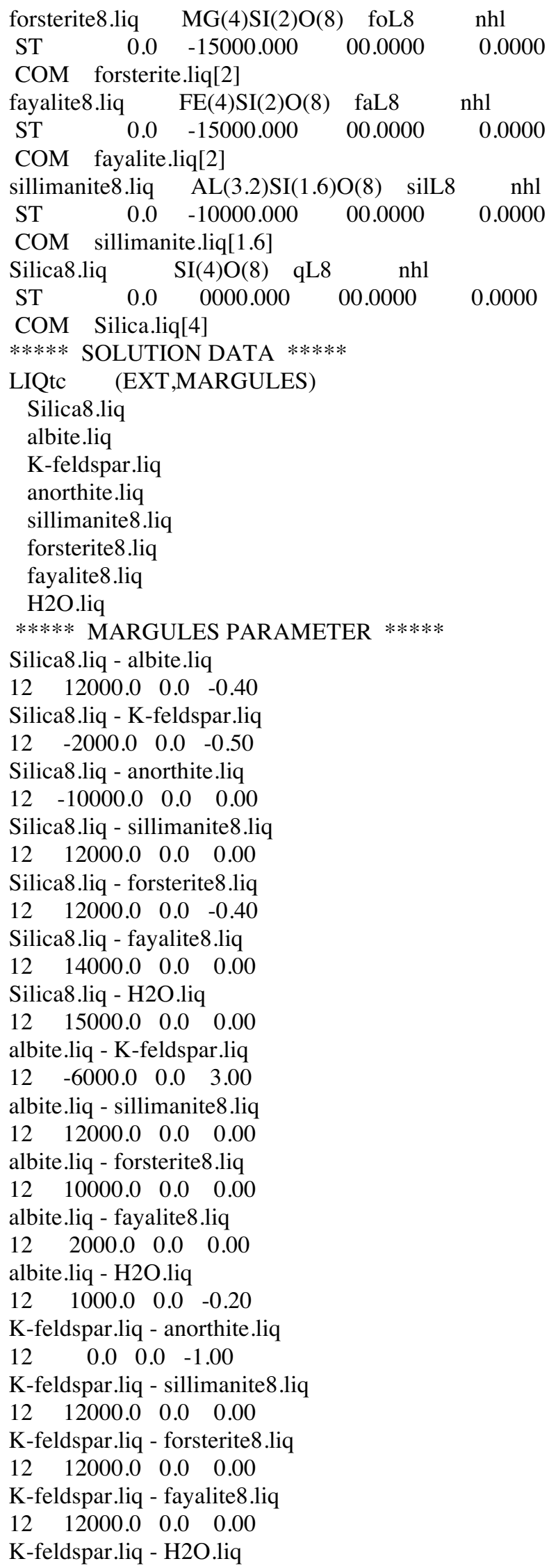


$\begin{array}{llll}12 & 11000.0 & 0.0 & -0.45\end{array}$

anorthite.liq - H2O.liq

$\begin{array}{llll}12 & 9000.0 & 0.0 & -0.85\end{array}$

sillimanite8.liq - forsterite8.liq

$\begin{array}{llll}12 & 12000.0 & 0.0 & 0.00\end{array}$

sillimanite8.liq - fayalite8.liq

$\begin{array}{llll}12 & 12000.0 & 0.0 & 0.00\end{array}$

sillimanite8.liq - H2O.liq

$\begin{array}{llll}12 & 16000.0 & 0.0 & 0.00\end{array}$

forsterite8.liq - fayalite8.liq

$\begin{array}{llll}12 & 18000.0 & 0.0 & 0.00\end{array}$

forsterite8.liq - $\mathrm{H} 2 \mathrm{O}$.liq

$\begin{array}{llll}12 & 11000.0 & 0.0 & -0.50\end{array}$

fayalite8.liq - H2O.liq

$\begin{array}{llll}12 & 12000.0 & 0.0 & 0.00\end{array}$ 


\section{Appendix F - Additional phase equilibrium diagrams}

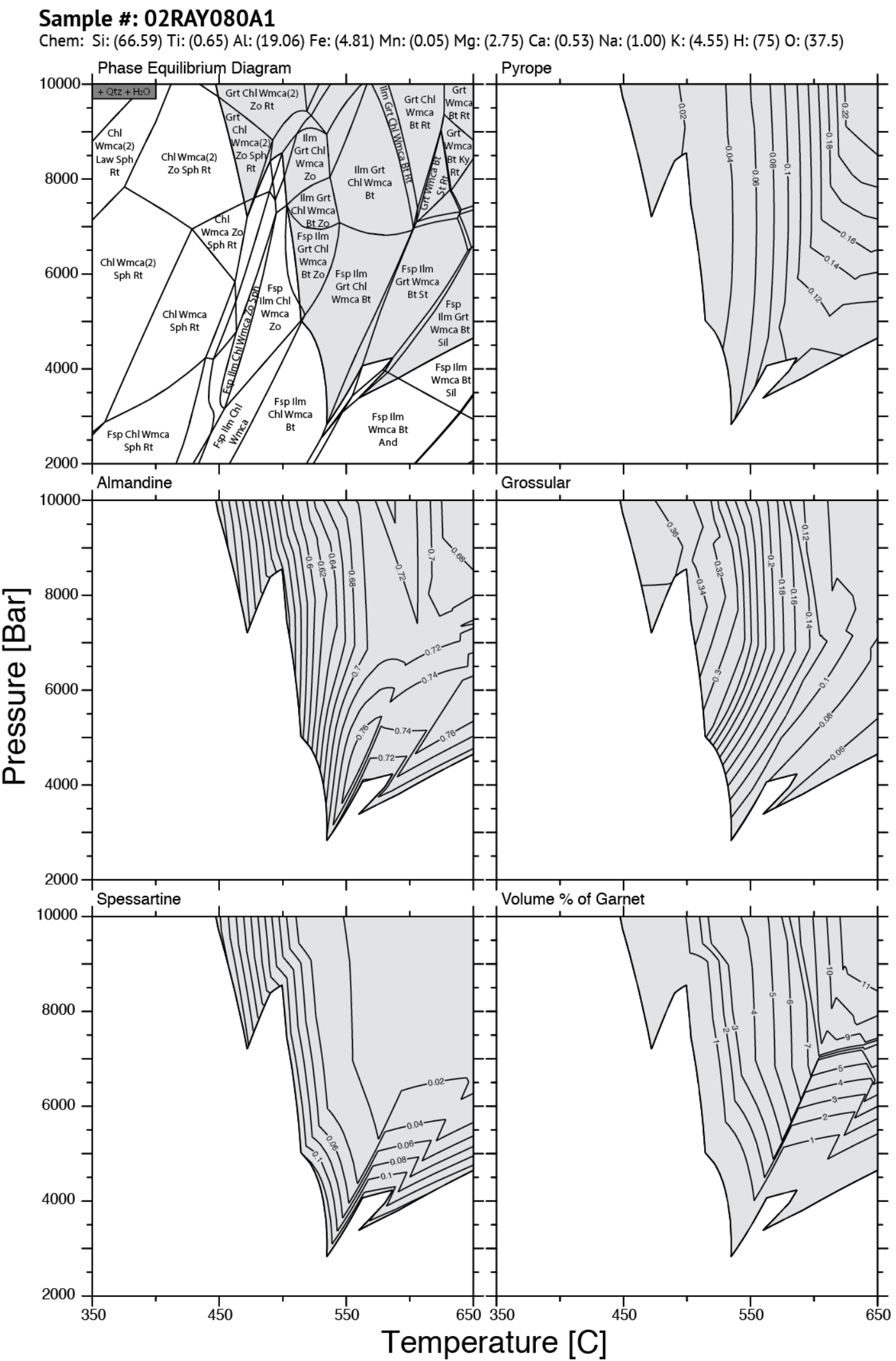


Sample \#: 02RAYG039C1

Chem: Si: (68.43) Ti: (0.56) Al: (17.49) Fe: (4.80) Mn: (0.11) Mg: (2.37) Ca: (0.64) Na: (1.12) K: (4.50) H: (75) O: (37.5)




Sample \#: 02RAYG141A1

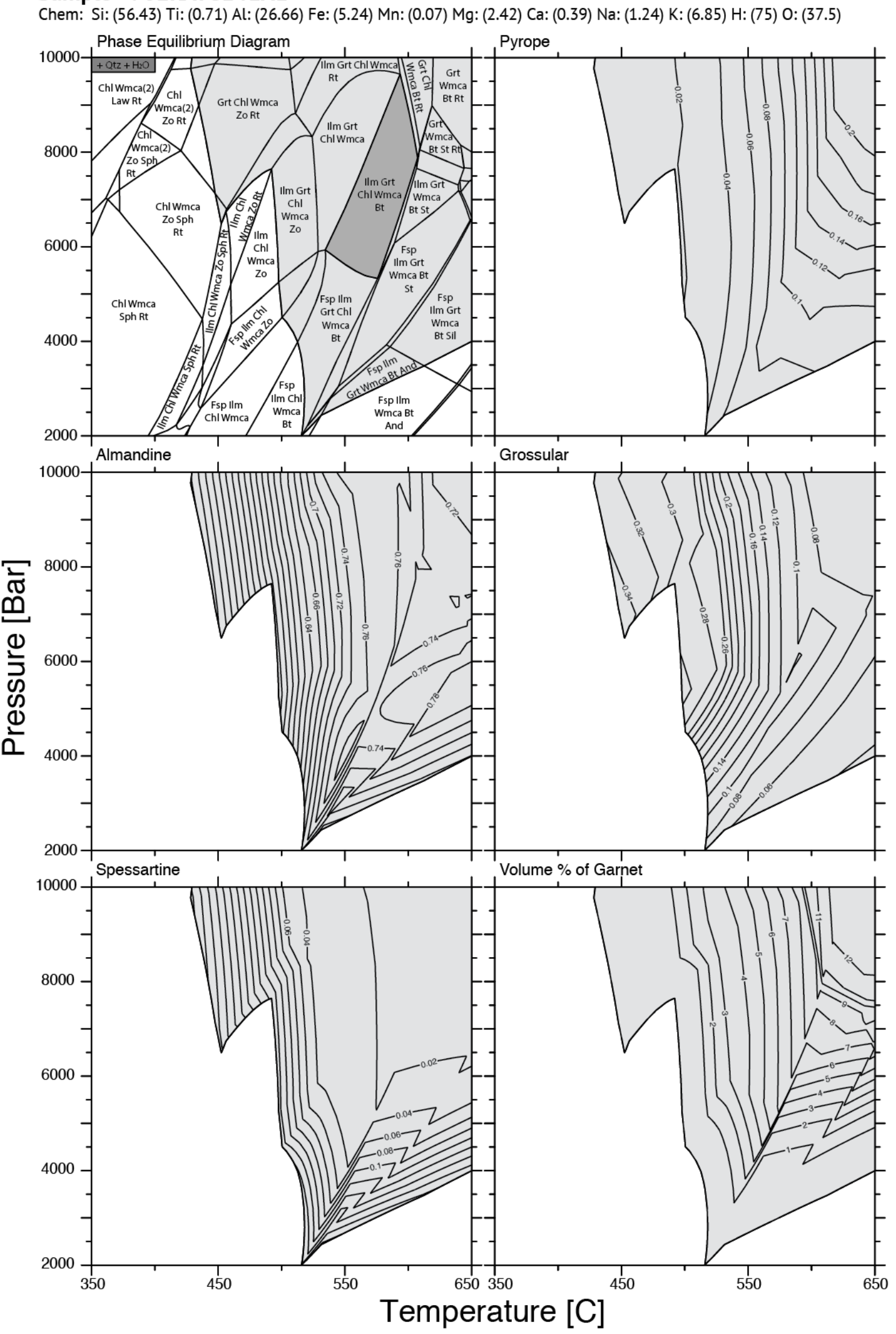


Sample \#: 15RAYJR230A1
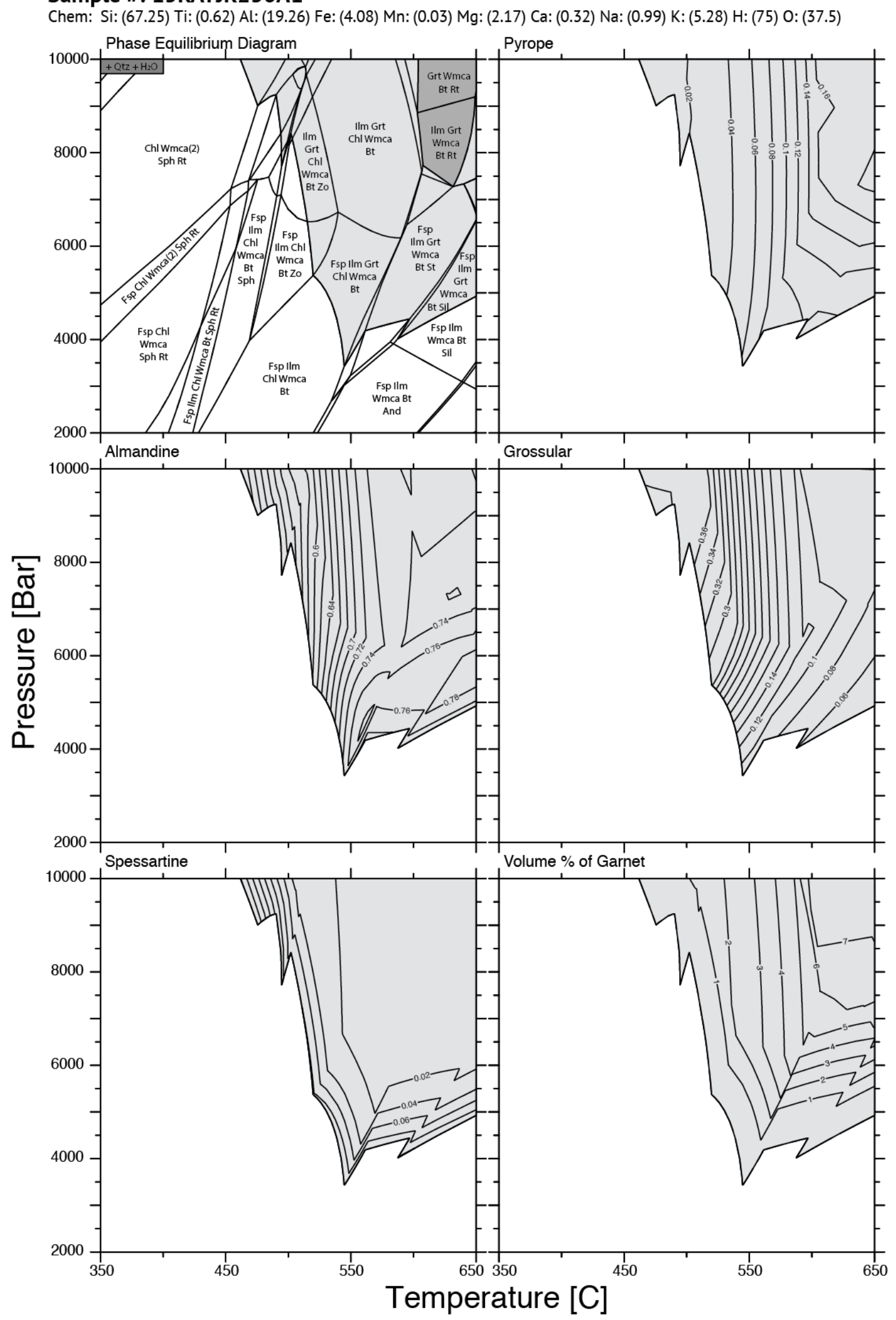
Sample \#: 15RAYJR231A1

Chem: Si: (56.58) Ti: (0.70) Al: (24.28) Fe: (6.56) Mn: (0.07) Mg: (3.26) Ca: (0.79) Na: (0.91) K: (6.85) H: (75) O: (37.5)

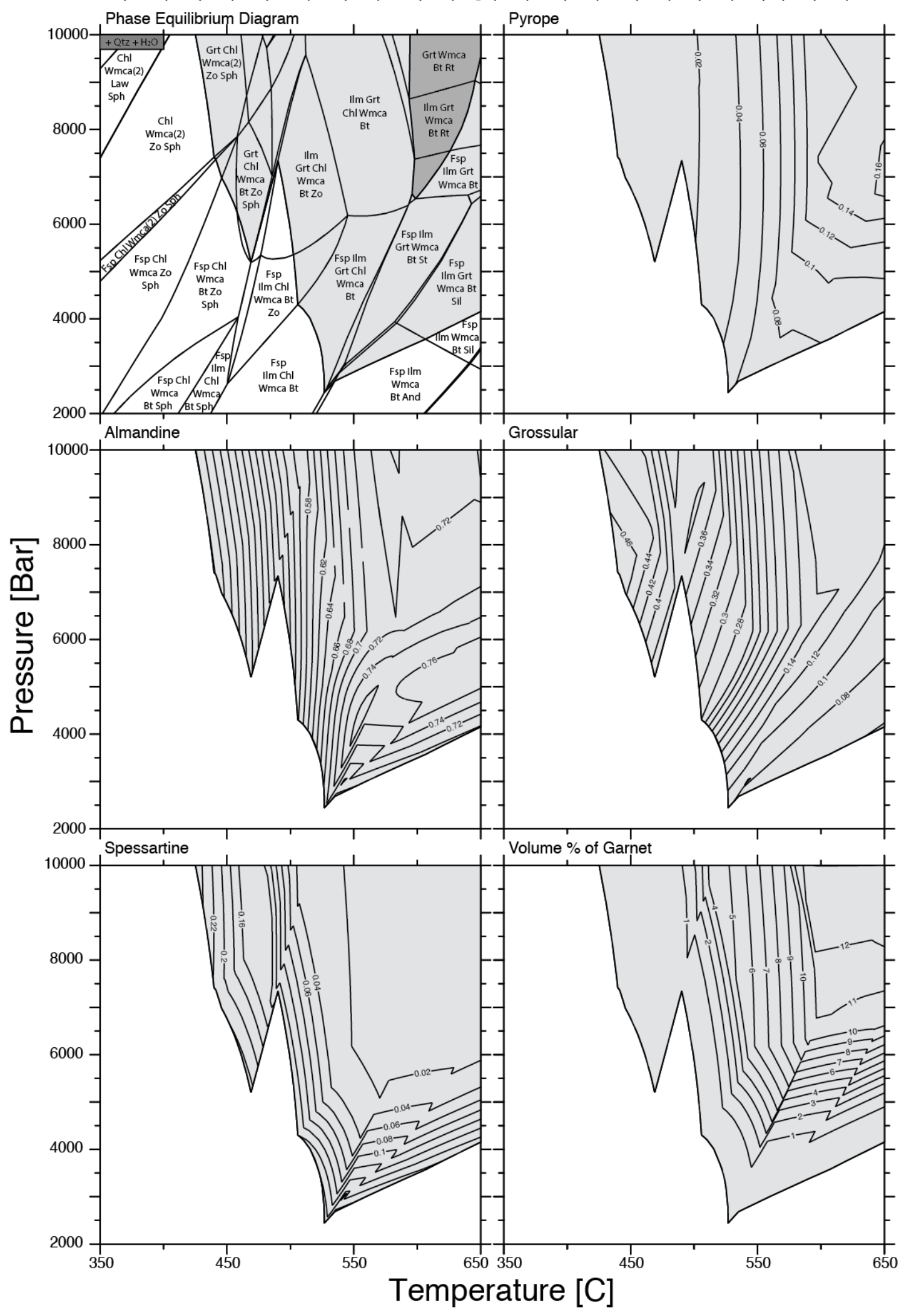


Sample \#: 15RAYJR232A1

Chem: Si: (63.01) Ti: (0.64) Al: (19.80) Fe: (5.81) Mn: (0.06) Mg: (2.84) Ca: (0.78) Na: (1.33) K: (5.73) H: (75) O: (37.5)

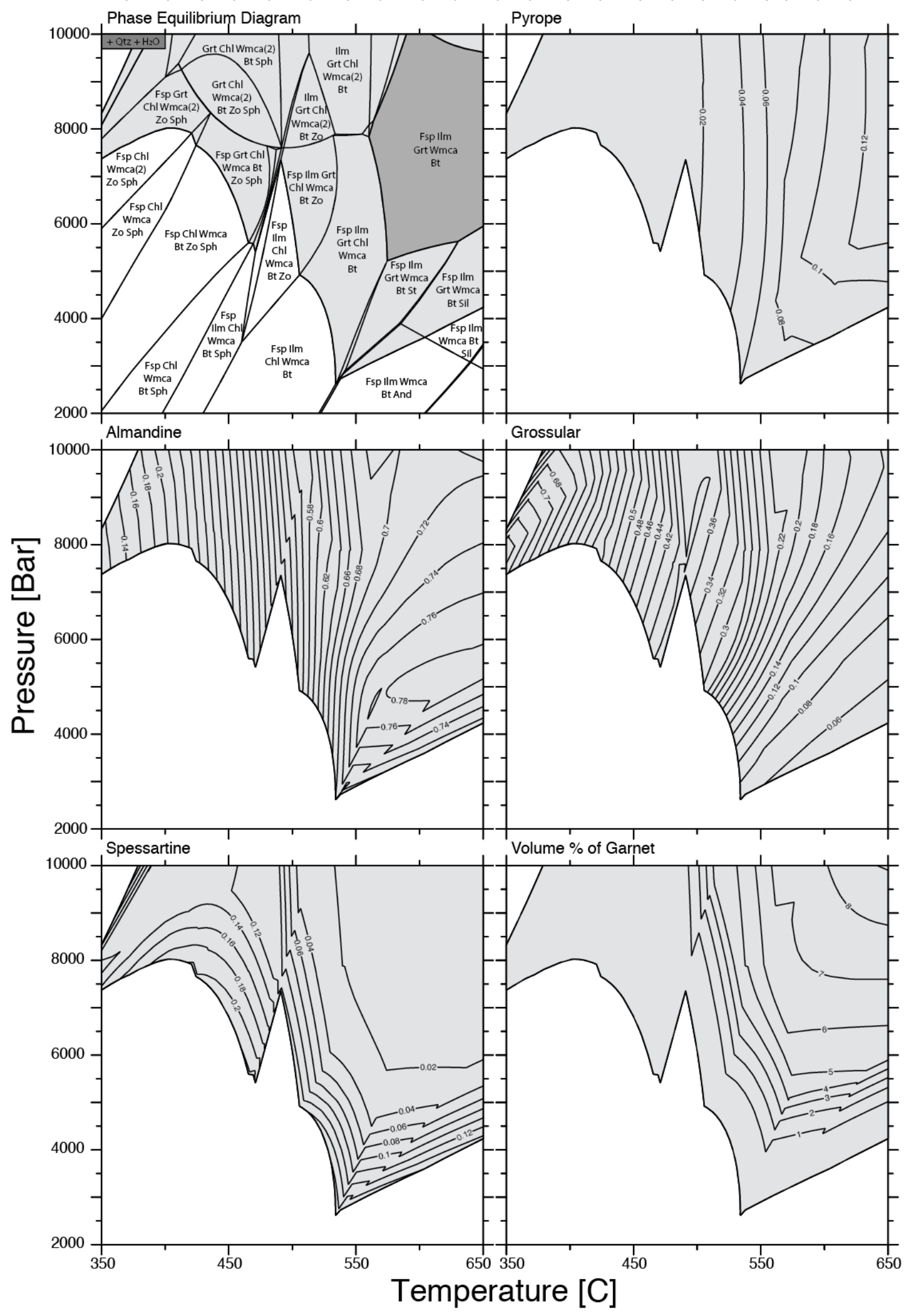


Sample \#: 15RAYJR233A1

Chem: Si: (65.39) Ti: (0.47) Al: (17.88) Fe: (4.71) Mn: (0.25) Mg: (3.35) Ca: (0.59) Na: (1.92) K: (5.44) H: (75) O: (37.5)

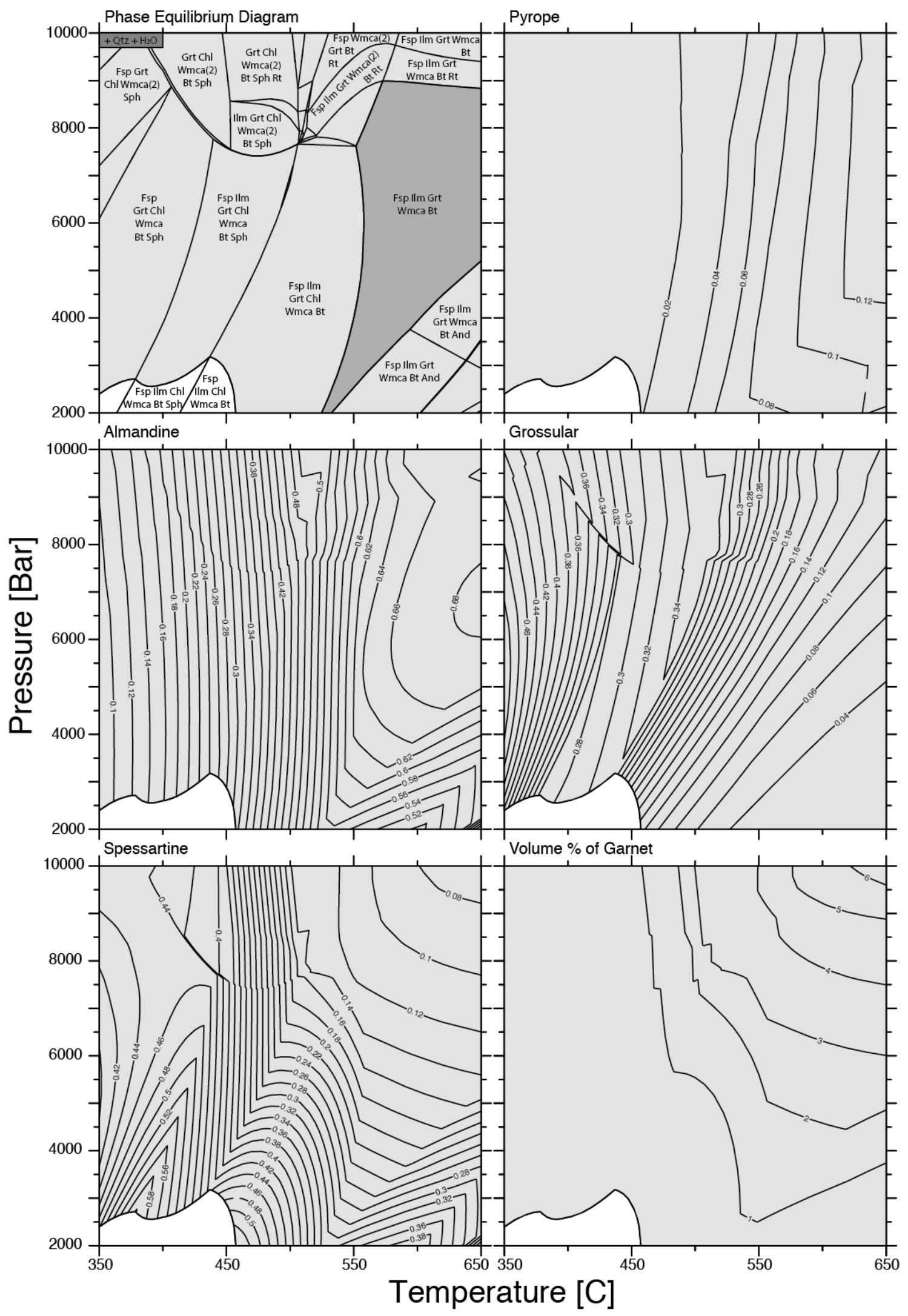


Sample \#: 15RAYJR235A1

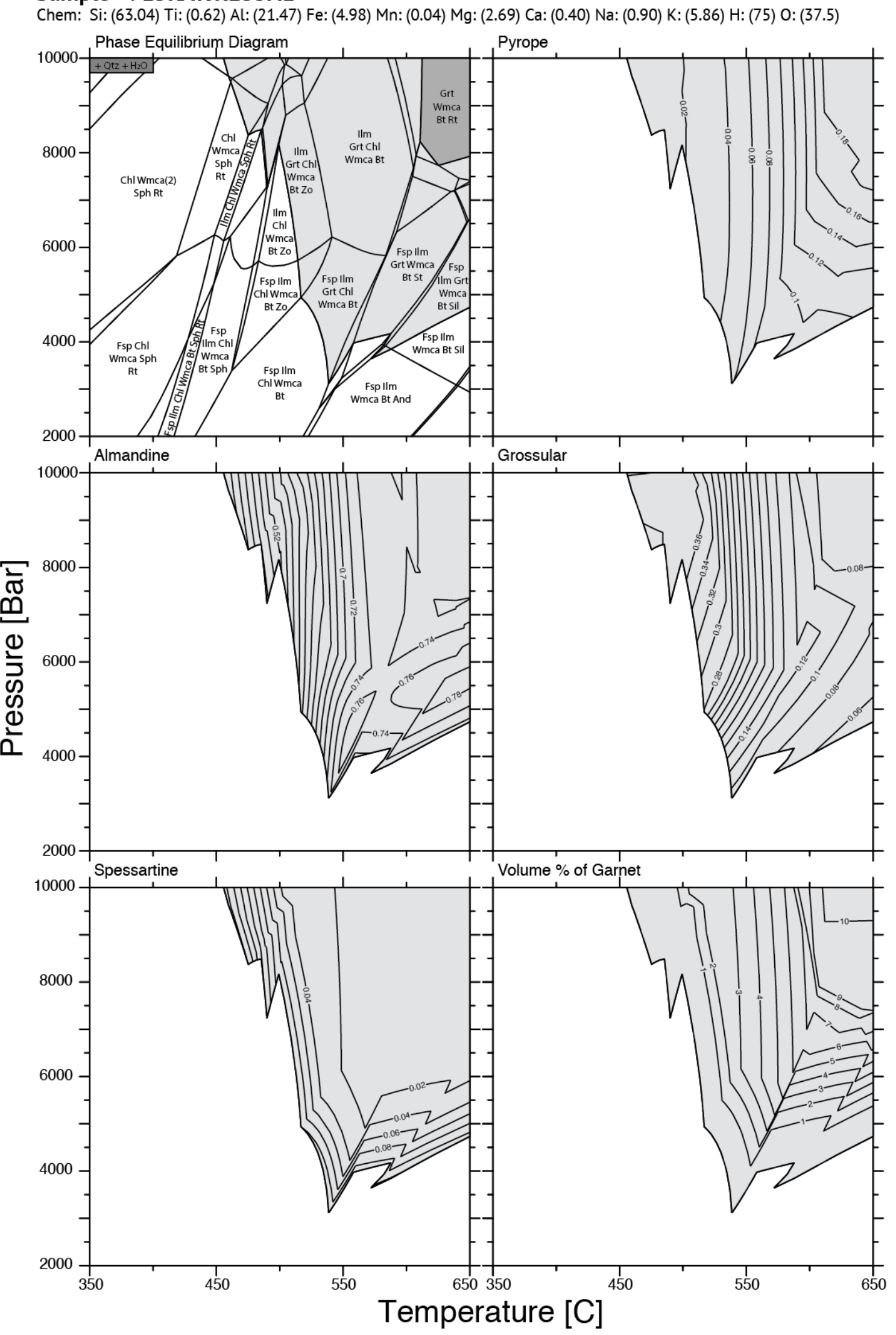


Sample \#: 15RAYJR236B1
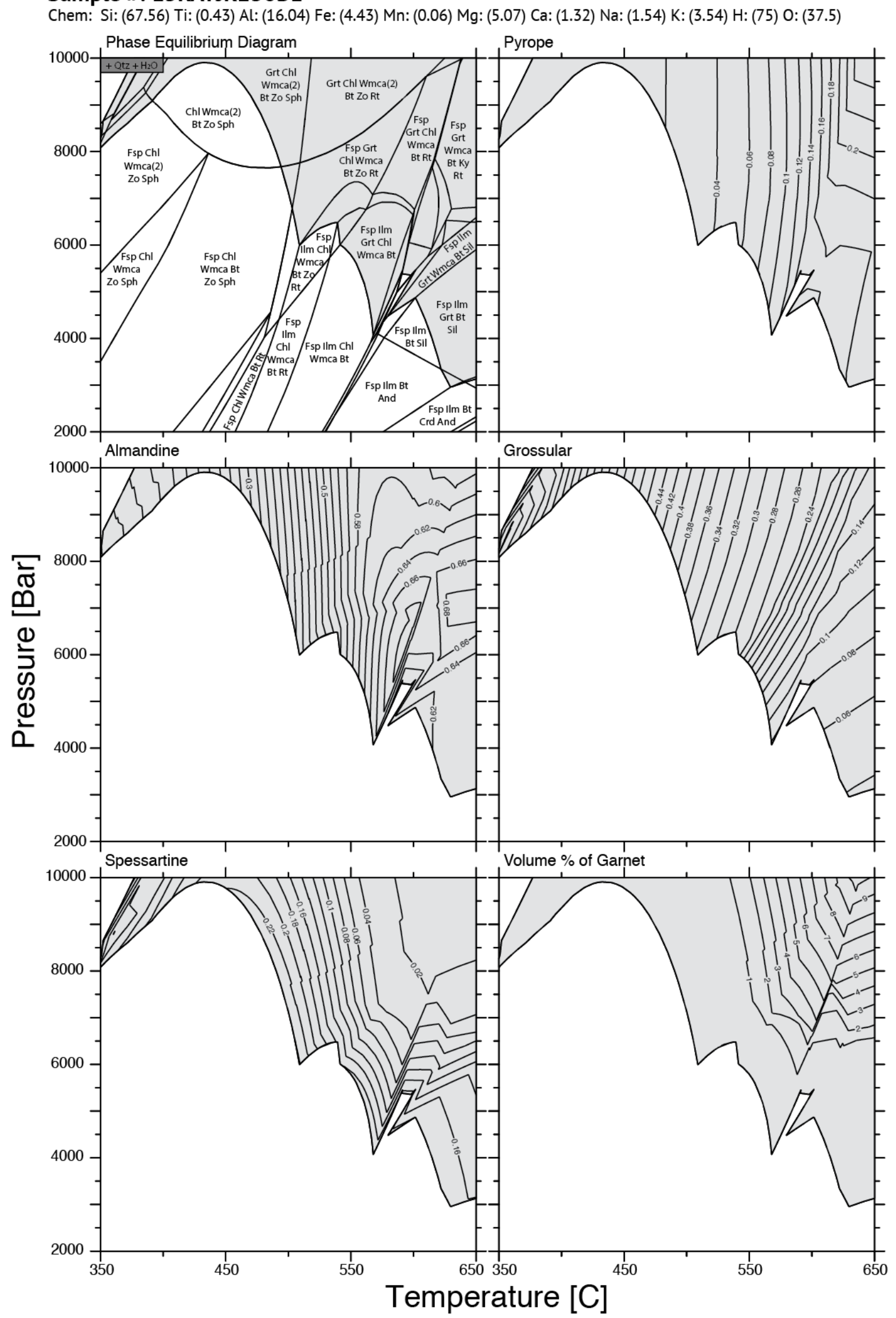
Sample \#: 15RAYJR236B2

Chem: Si: (74.62) Ti: (0.50) Al: (13.89) Fe: (3.69) Mn: (0.06) Mg: (2.25) Ca: (0.92) Na: (0.54) K: (3.53) H: (75) O: (37.5)

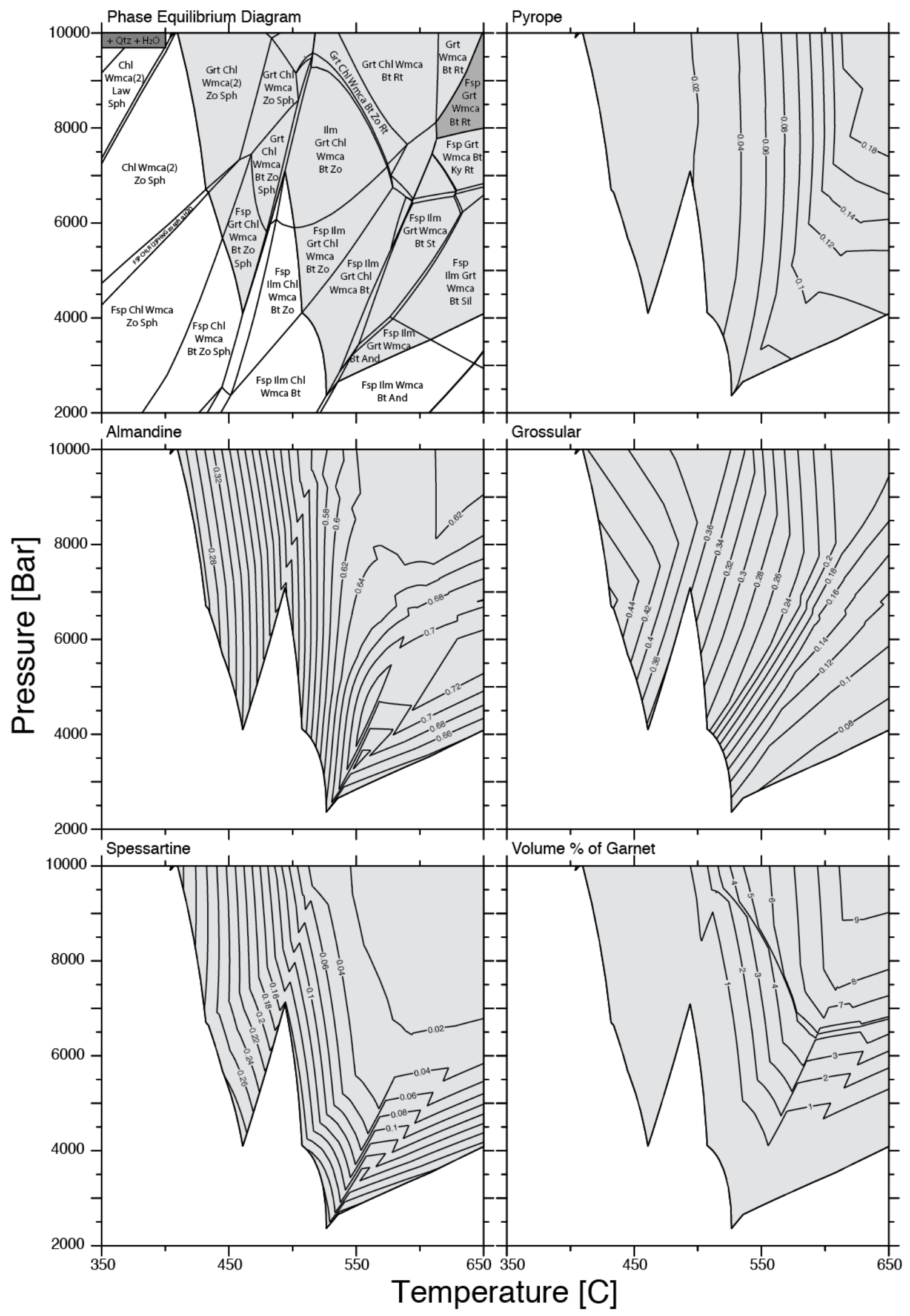


Sample \#: 15RAYJR244A1

Chem: Si: (67.65) Ti: (0.51) Al: (17.57) Fe: (4.69) Mn: (0.08) Mg: (2.73) Ca: (1.06) Na: (0.84) K: (4.87) H: (75) O: (37.5)

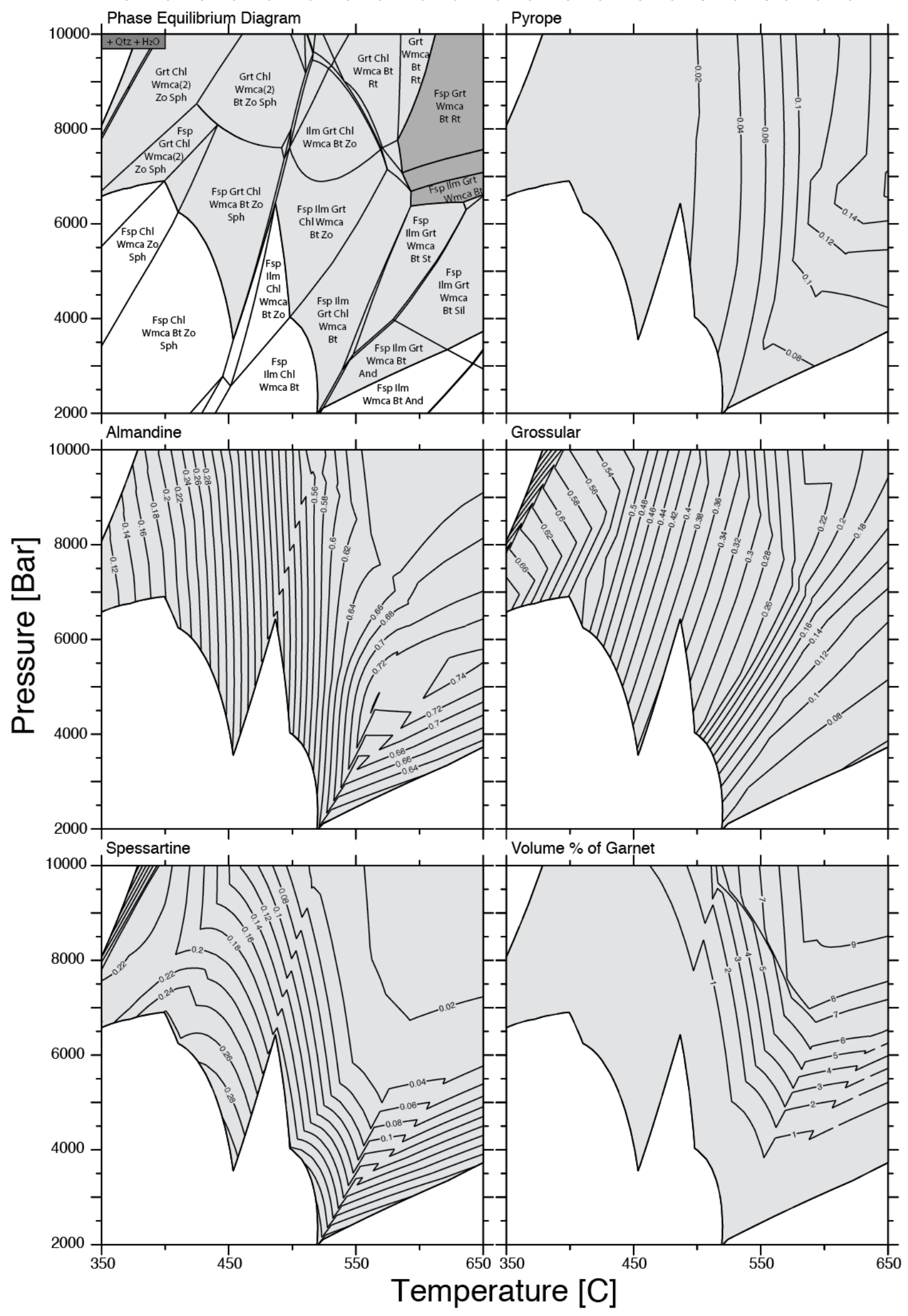


Sample \#: 15RAYJR244A2

Chem: Si: (63.26) Ti: (0.50) Al: (20.77) Fe: (4.73) Mn: (0.06) Mg: (2.38) Ca: (0.88) Na: (0.83) K: (6.57) H: (75) 0: (37.5)

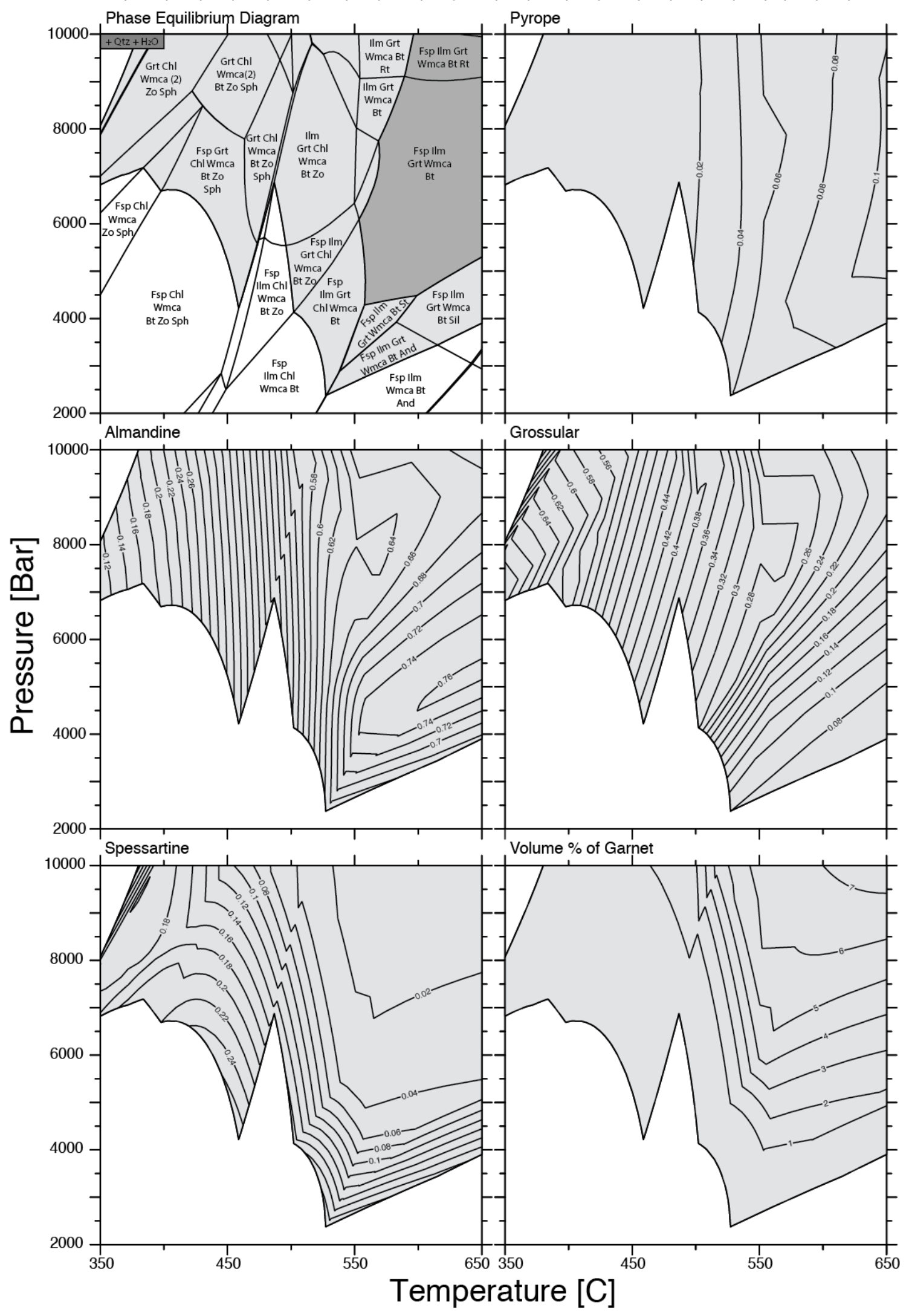


Sample \#: 15RAYJR245A1

Chem: Si: (61.72) Ti: (0.69) Al: (19.73) Fe: (5.93) Mn: (0.16) Mg: (3.59) Ca: (1.08) Na: (1.40) K: (5.68) H: (75) O: (37.5)

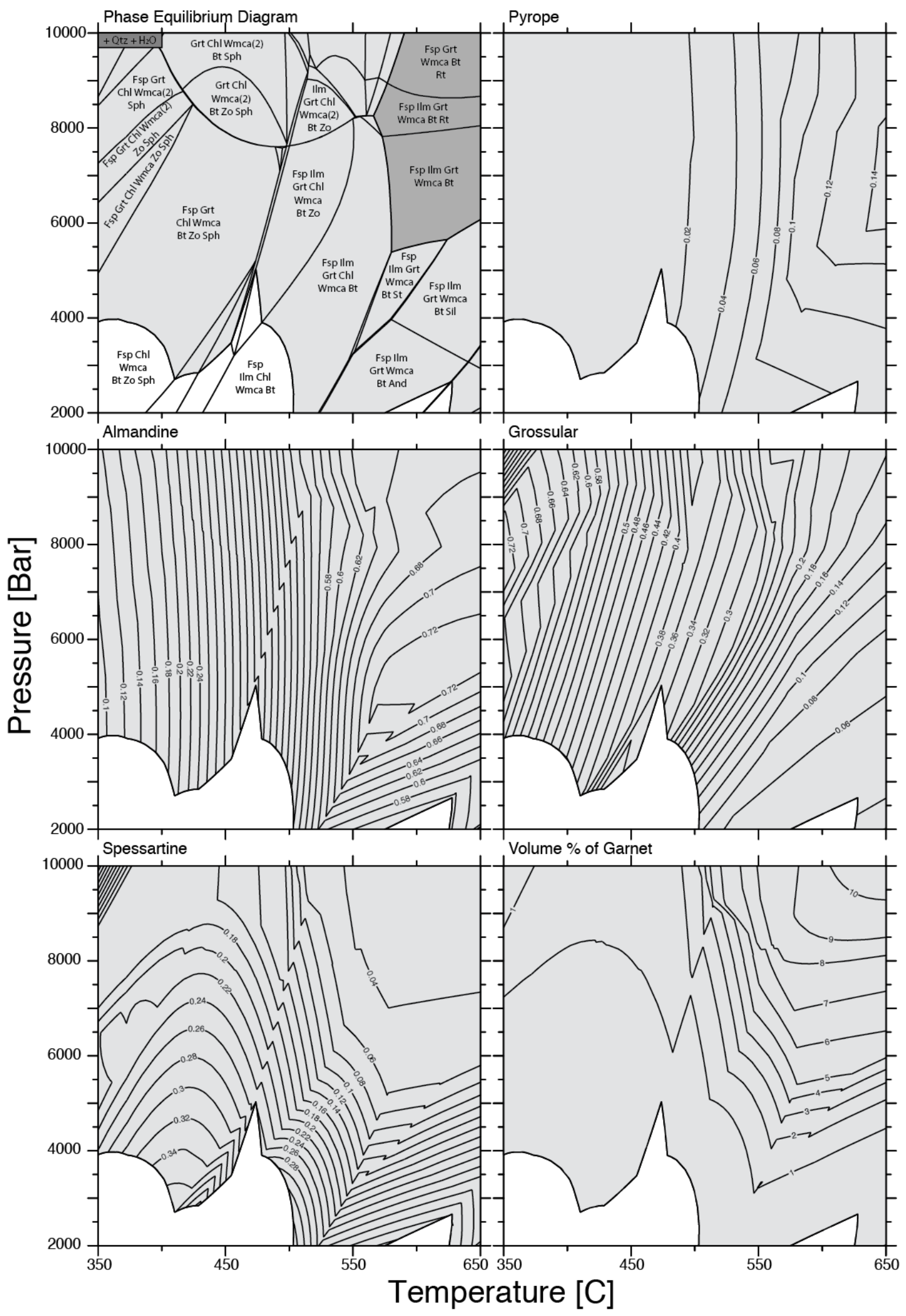


Sample \#: 15RAYJR248A1

Chem: Si: (61.13) Ti: (0.56) Al: (20.18) Fe: (5.75) Mn: (0.07) Mg: (3.10) Ca: (1.43) Na: (1.62) K: (6.16) H: (75) 0: (37.5)
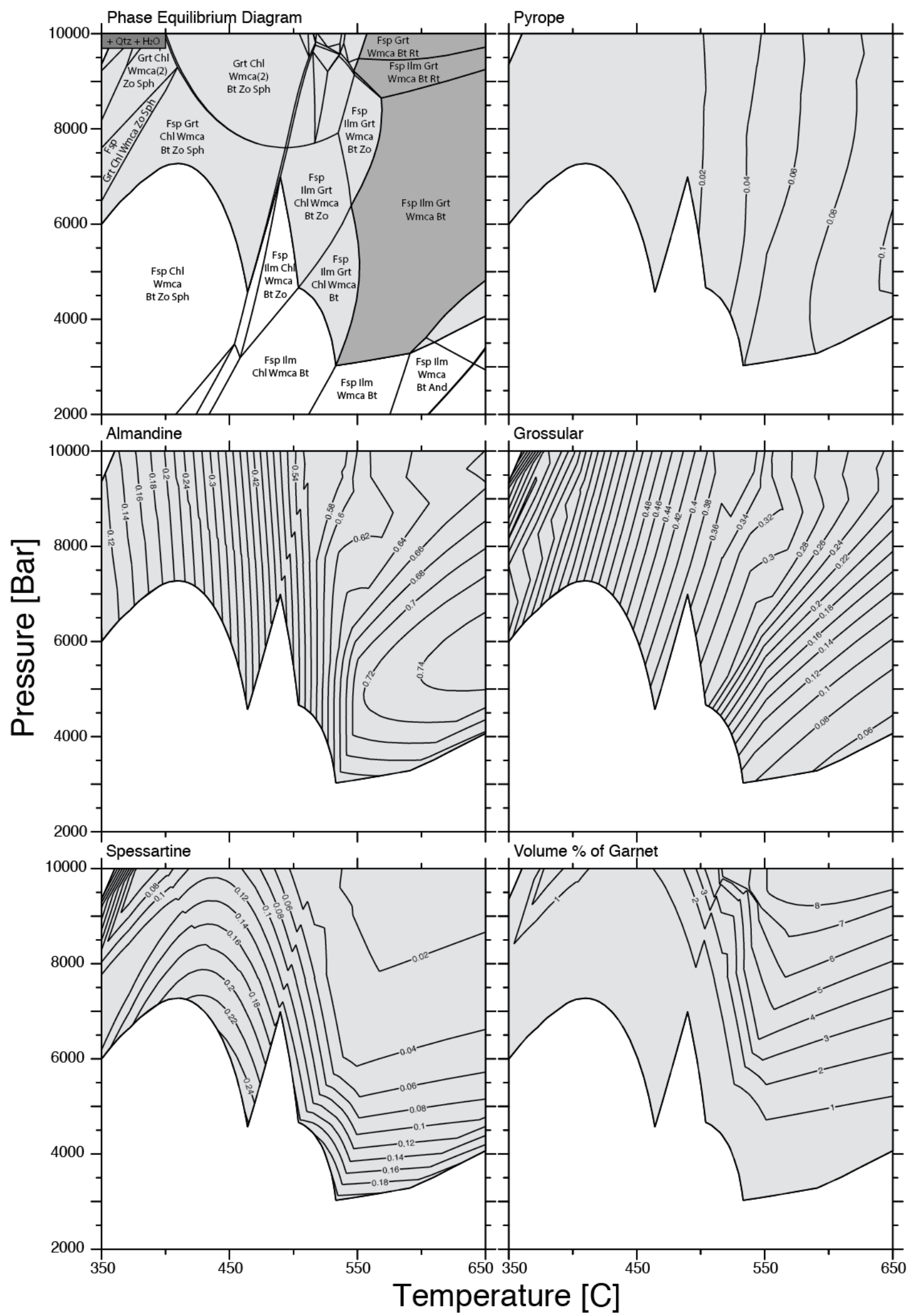
Sample \#: 15RAYJR249A1

Chem: Si: (70.88) Ti: (0.43) Al: (16.20) Fe: (2.98) Mn: (0.05) Mg: (1.84) Ca: (0.80) Na: (1.91) K: (4.90) H: (75) O: (37.5)

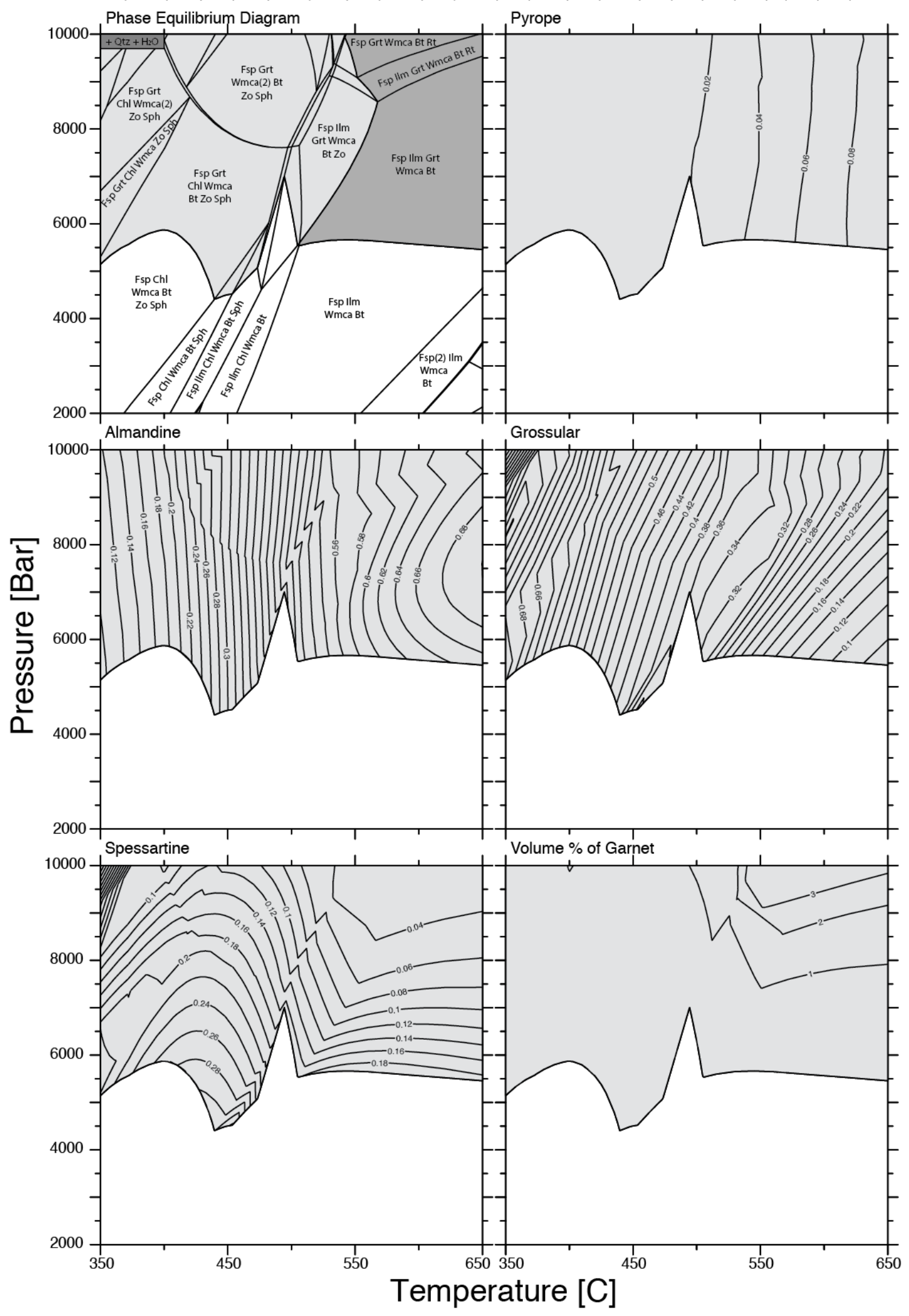


Sample \#: 00GGA218A1

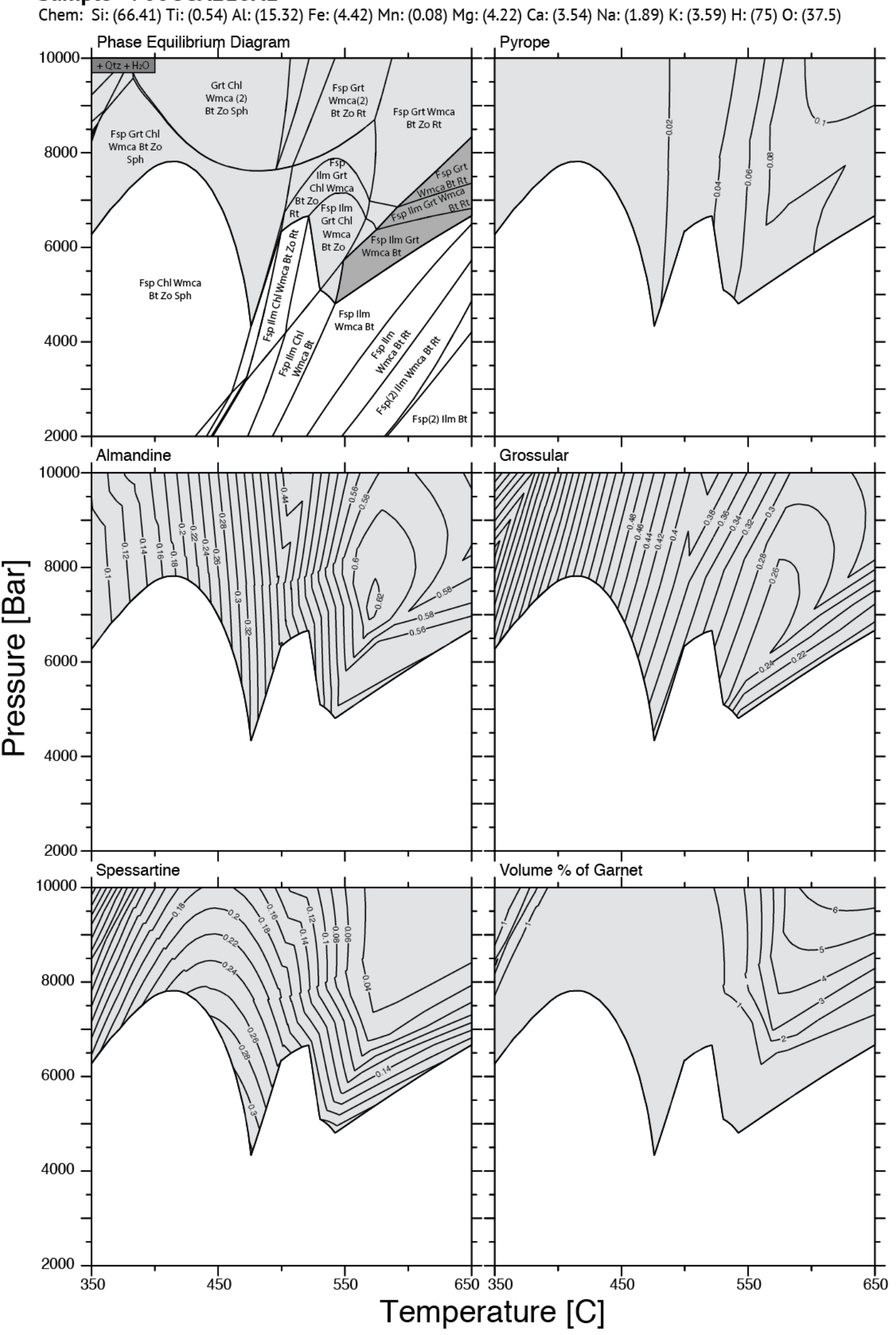


Sample \#: 00RAY166A1

Chem: Si: (62.65) Ti: (0.53) Al: (19.54) Fe: (4.07) Mn: (0.08) Mg: (2.31) Ca: (2.43) Na: (3.70) K: (4.69) H: (75) O: (37.5)

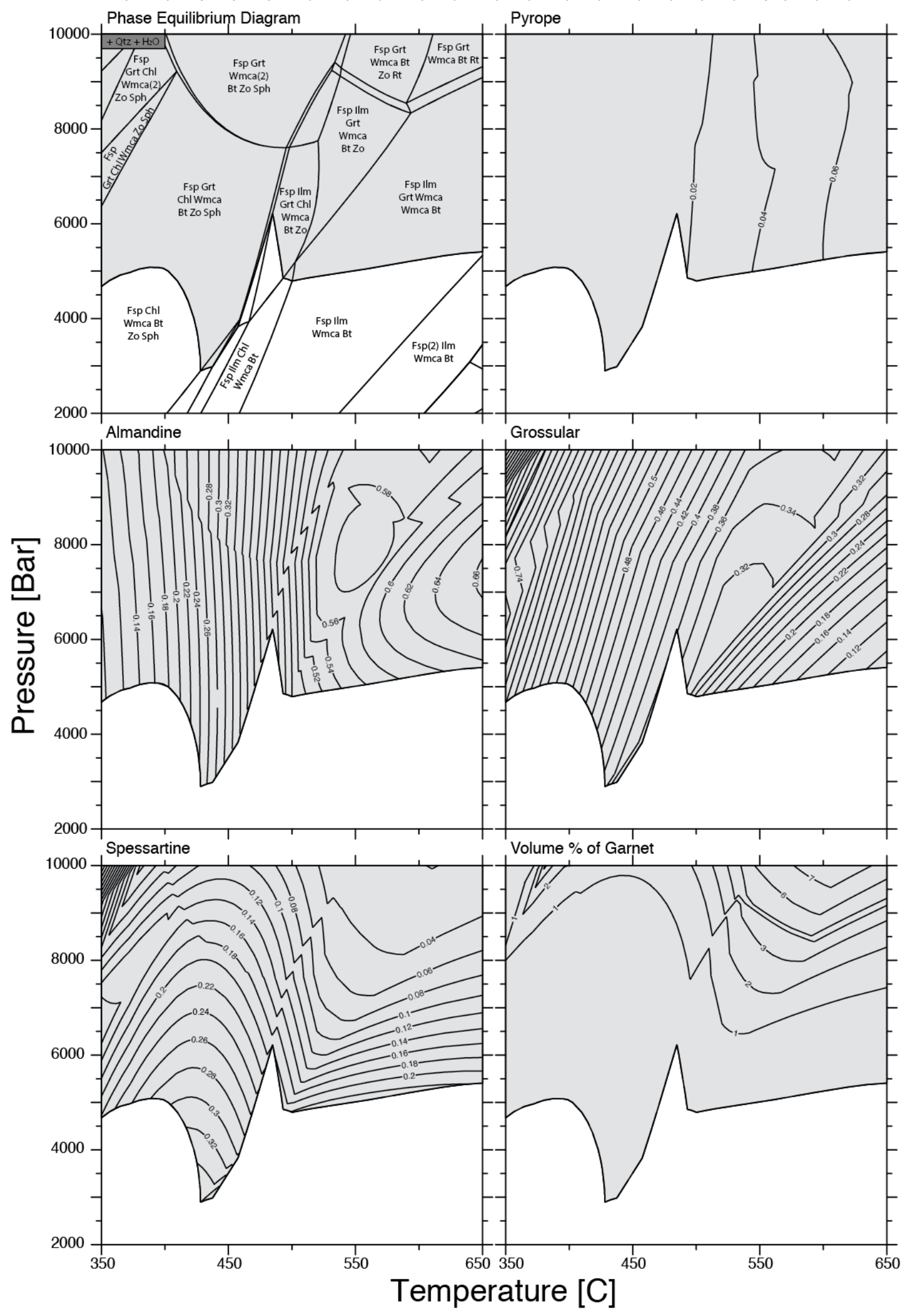




\section{Sample \#: 03GGA451A1}

Chem: Si: (65.61) Ti: (0.63) Al: (16.83) Fe: (6.41) Mn: (0.22) Mg: (2.80) Ca: (0.91) Na: (1.09) K: (5.50) H: (75) O: (37.5)

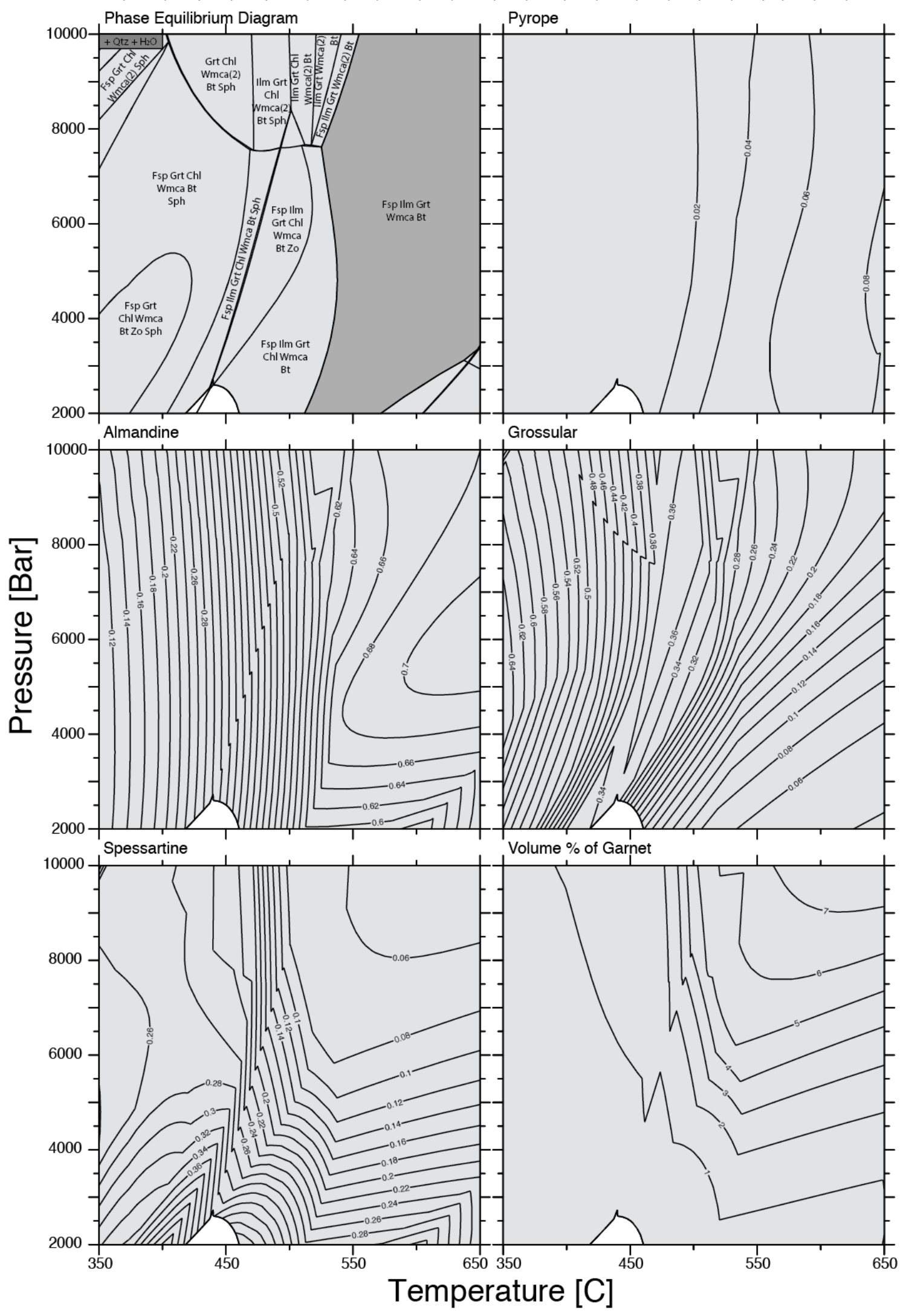


Sample \#: 11RAYTD056A1

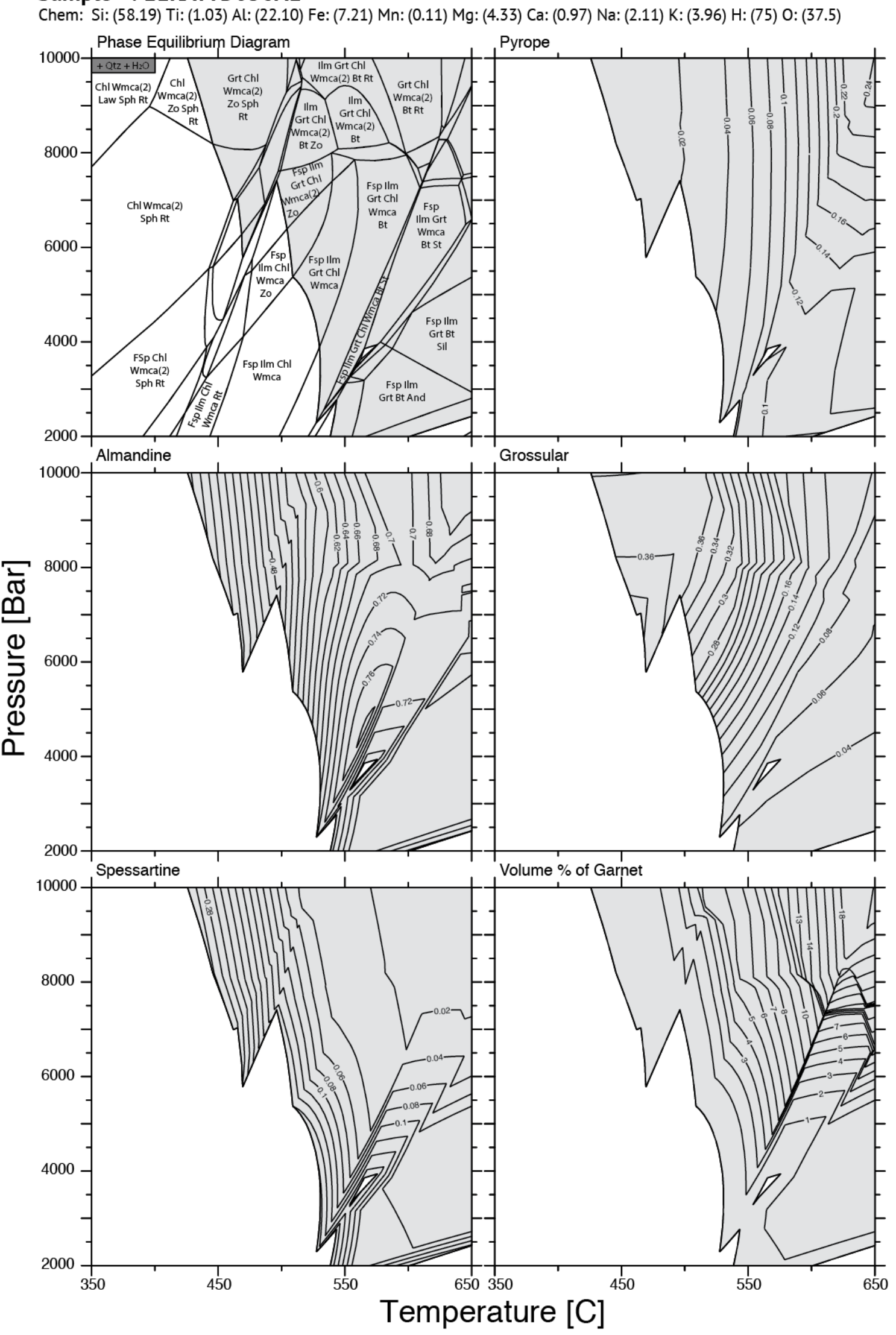


Sample \#: 11RAYTK008A1

Chem: Si: (72.65) Ti: (0.48) Al: (15.25) Fe: (3.76) Mn: (0.09) Mg: (1.96) Ca: (0.55) Na: (0.86) K: (4.41) H: (75) O: (37.5)




Sample \#: 15RAYJR239A1

Chem: Si: (55.61) Ti: (0.69) Al: (25.92) Fe: (6.52) Mn: (0.17) Mg: (3.20) Ca: (0.14) Na: (1.27) K: (6.47) H: (75) O: (37.5)

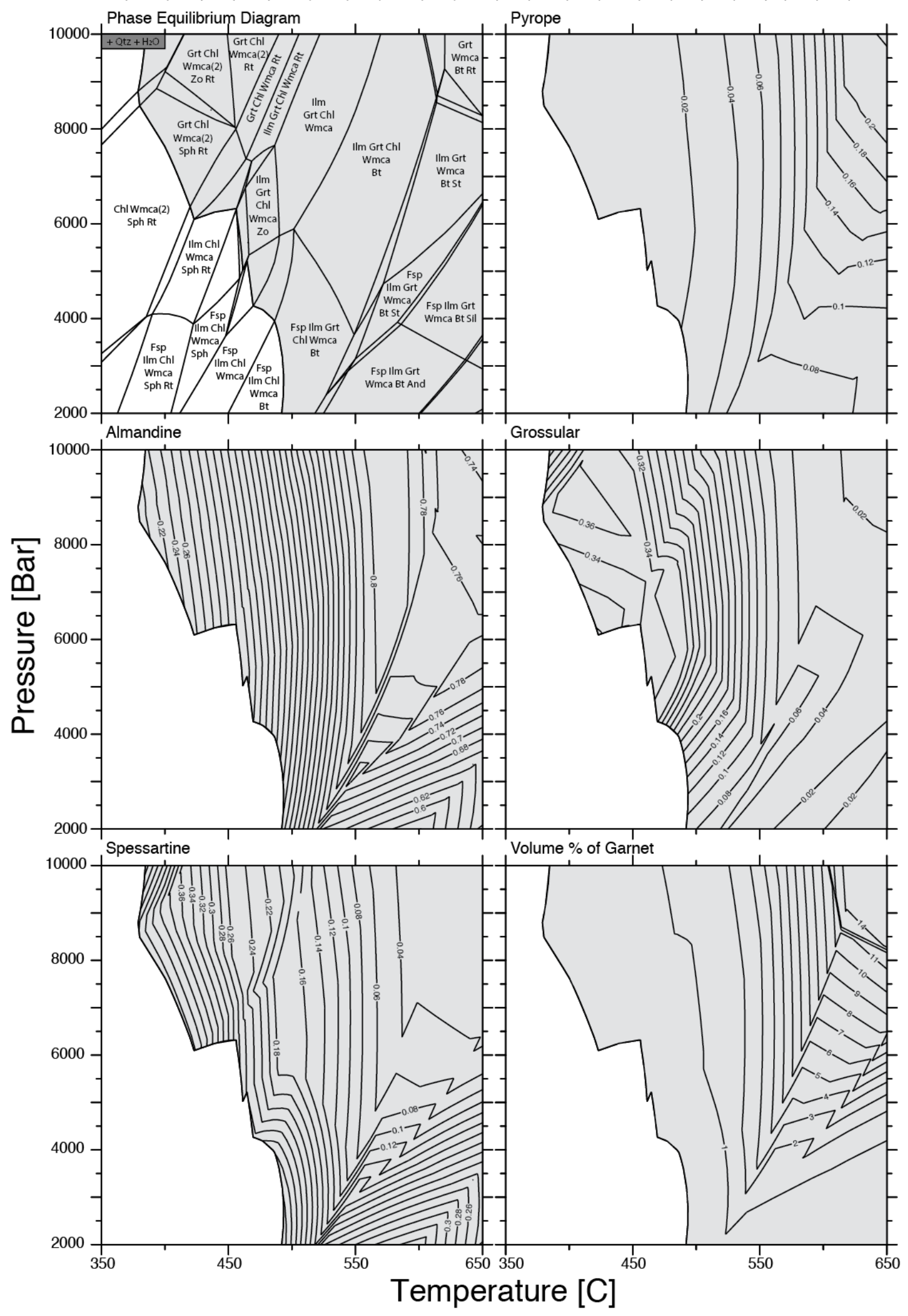


Sample \#: 15RAYJR240A1
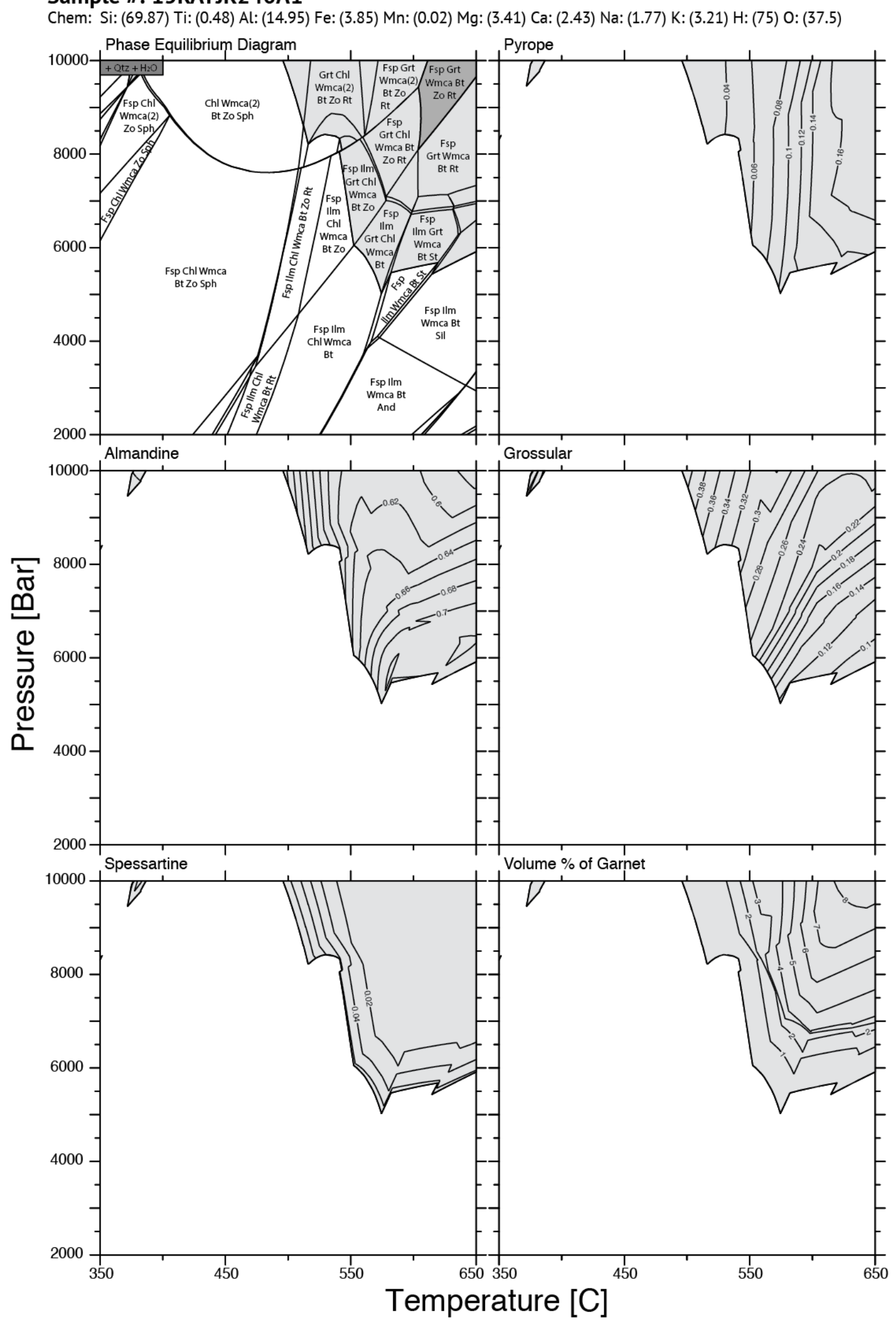
Sample \#: 15RAYJR242A1

Chem: Si: (53.70) Ti: (0.88) Al: (23.75) Fe: (8.07) Mn: (0.25) Mg: (3.52) Ca: (0.39) Na: (0.88) K: (8.57) H: (75) O: (37.5)

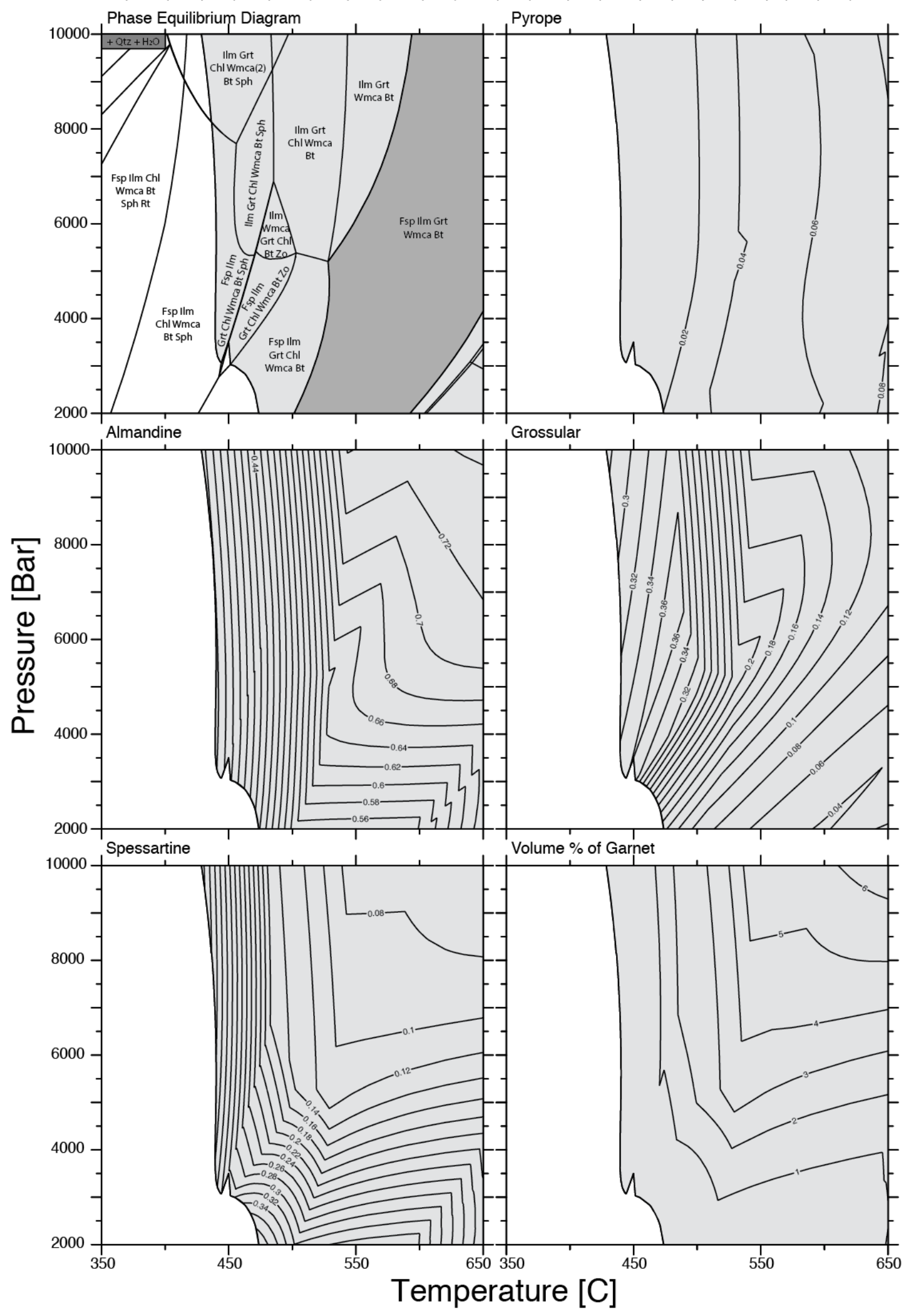




\section{Sample \#: 15RAYJR242B1}

Chem: Si: (70.21) Ti: (0.49) Al: (14.32) Fe: (4.71) Mn: (0.13) Mg: (2.15) Ca: (0.93) Na: (2.22) K: (4.83) H: (75) O: (37.5)

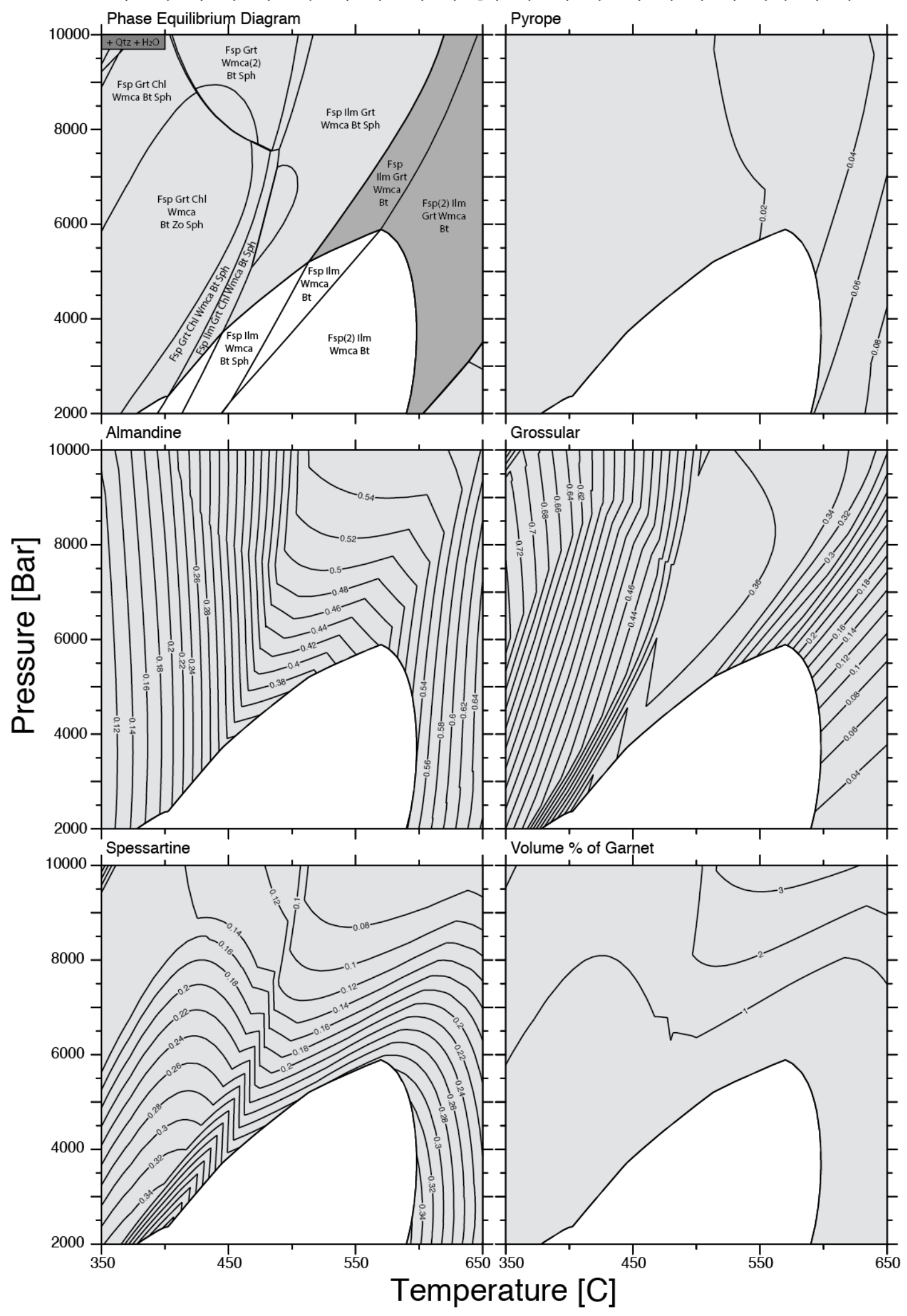


Sample \#: 15RAYJR243A1

Chem: Si: (70.63) Ti: (0.58) Al: (15.60) Fe: (4.96) Mn: (0.09) Mg: (2.31) Ca: (0.23) Na: (0.57) K: (5.03) H: (75) 0: (37.5)

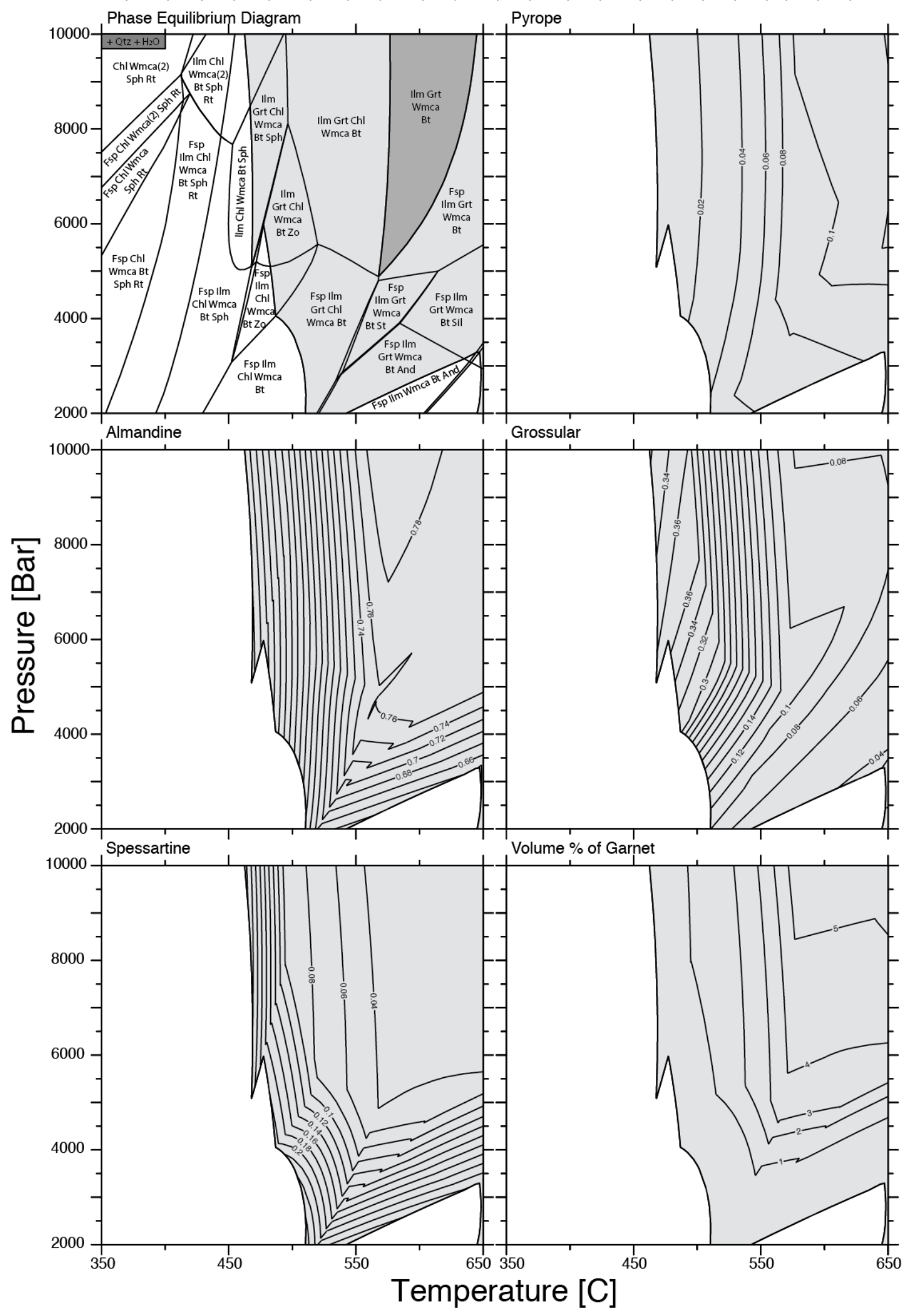


Sample \#: 03GGAR040A1

Chem: Si: (58.66) Ti: (0.66) Al: (22.45) Fe: (5.46) Mn: (0.16) Mg: (3.43) Ca: (0.59) Na: (1.73) K: (6.86) H: (75) O: (37.5)

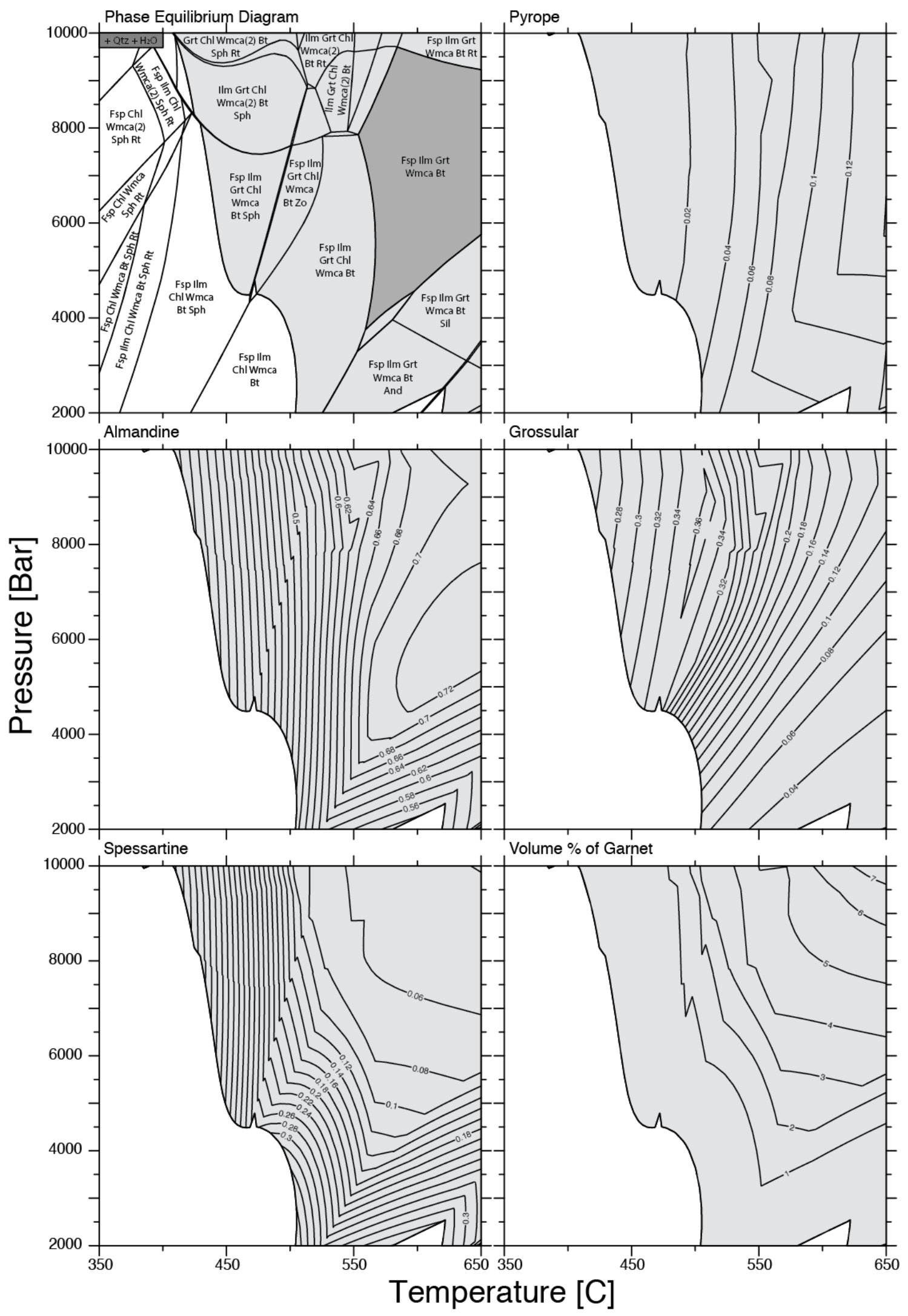


Sample \#: 11RAYAZ451A1

Chem: Si: (56.10) Ti: (1.08) Al: (23.49) Fe: (7.55) Mn: (0.09) Mg: (3.49) Ca: (0.96) Na: (2.16) K: (5.06) H: (75) O: (37.5)

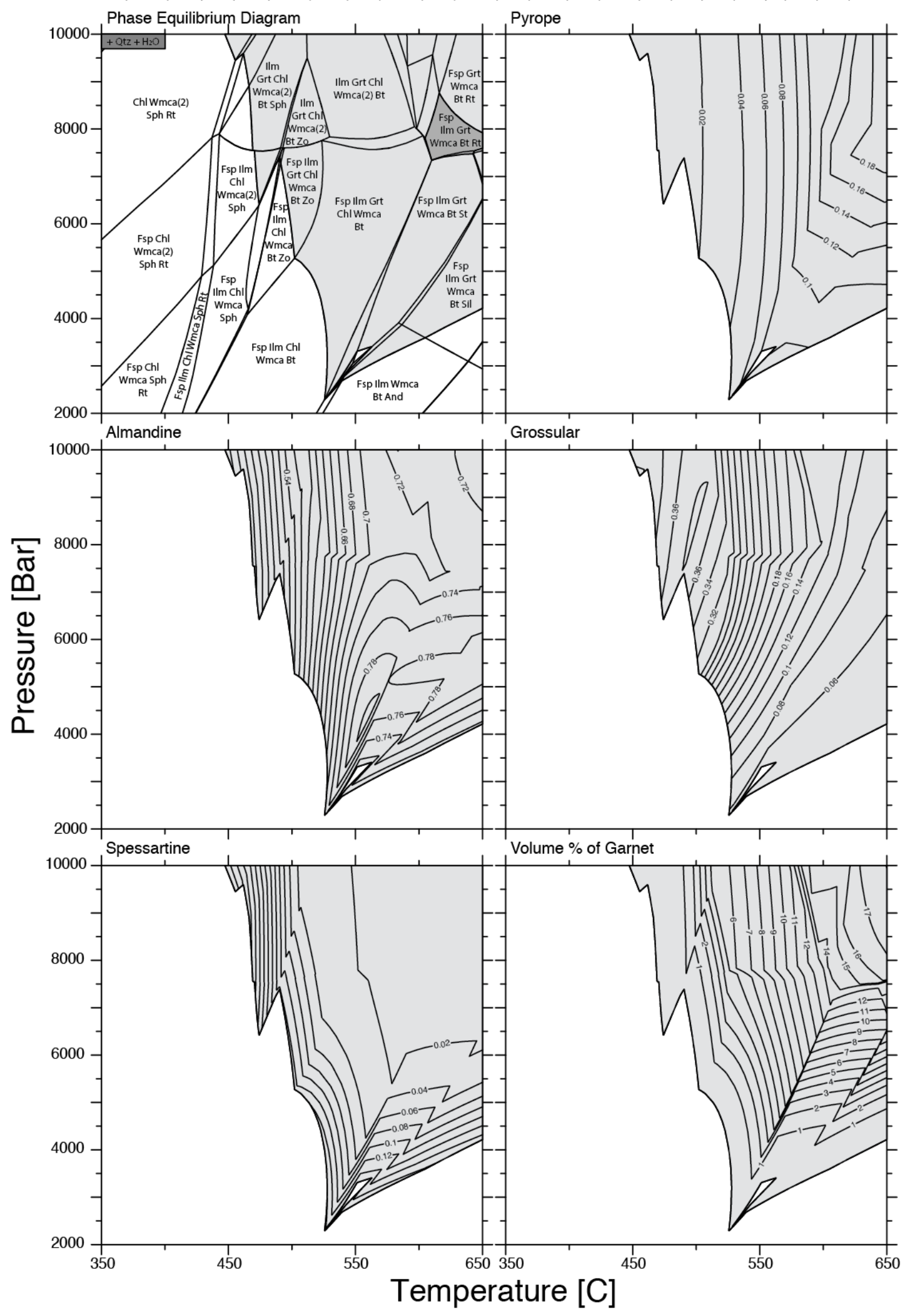




\section{References}

Anczkiewicz, R., Platt, J. P., Thirlwall, M. F., and Wakabayashi, J., 2004, Franciscan subduction off to a slow start: evidence from high-precision Lu-Hf garnet ages on high grade-blocks: Earth and Planetary Science Letters, v. 225, no. 1-2, p. 147-161.

Anczkiewicz, R., and Thirlwall, M. F., 2003, Improving precision of Sm-Nd garnet dating by $\mathrm{H} 2 \mathrm{SO} 4$ leaching: a simple solution to the phosphate inclusion problem: in: D. Vance, W. Mueller, I.M. Villa (Eds.), Geochronology: Linking the Isotopic Record with Petrology and Textures, Spec. Publ.-Geol. Soc. Lond., v. 220, p. 83-91.

Baldwin, J. A., Powell, R., Brown, M., Moraes, R., and Fuck, R. A., 2005, Modelling of mineral equilibria in ultrahigh-temperature metamorphic rocks from the AnapolisItaucu Complex, central Brazil: Journal of Metamorphic Geology, v. 23, no. 7, p. 511531.

Berman, R. G., Ryan, J. J., Gordey, S. P., and Villeneuve, M., 2007, Permian to Cretaceous polymetamorphic evolution of the Stewart River region, Yukon-Tanana terrane, Yukon, Canada: P-T evolution linked with in situ SHRIMP monazite geochronology: Journal of Metamorphic Geology, v. 25, no. 7, p. 803-827.

Berman, R. G., 1991, Thermobarometry Using Multi-Equilibrium Calculations - a New Technique, with Petrological Applications: Canadian Mineralogist, v. 29, p. 833-855. 
Berman, R. G., 1988, Internally-Consistent Thermodynamic Data for Minerals in the System $\mathrm{Na}_{2} \mathrm{O}-\mathrm{K}_{2} \mathrm{O}-\mathrm{CaO}-\mathrm{MgO}-\mathrm{FeO}-\mathrm{Fe}_{2} \mathrm{O}_{3}-\mathrm{Al}_{2} \mathrm{O}_{3}-\mathrm{SiO}_{2}-\mathrm{TiO}_{2}-\mathrm{H}_{2} \mathrm{O}-\mathrm{CO}_{2}$ : Journal of Petrology, v. 29, no. 2, p. 445-522.

Beranek, L. P., and Mortensen, J. K., 2011, The timing and provenance record of the Late Permian Klondike orogeny in northwestern Canada and arc-continent collision along western North America: Tectonics, v. 30, TC5017.

Beranek, L. P., Mortensen, J. K., Orchard, M. J., and Ullrich, T., 2010, Provenance of North American Triassic strata from west-central and southeastern Yukon: correlations with coeval strata in the Western Canada Sedimentary Basin and Canadian Arctic Islands: Canadian Journal of Earth Sciences, v. 47, no. 1, p. 53-73.

Caddick, M. J., Konopasek, J., and Thompson, A. B., 2010, Preservation of Garnet Growth Zoning and the Duration of Prograde Metamorphism: Journal of Petrology, v. 51, no. 11, p. 2327-2347.

Canil, D., Johnston, S. T., Evers, K., Shellnutt, J. G., and Creaser, R. A., 2003, Mantle exhumation in an early Paleozoic passive margin, northern Cordillera, Yukon: Journal of Geology, v. 111, no. 3, p. 313-327

Carlson, W. D., 2006, Rates of Fe, Mg, Mn, and Ca diffusion in garnet: American Mineralogist, v. 91, no. 1, p. 1-11. 
Cashman, K. V., and Ferry, J. M., 1988, Crystal size distribution (CSD) in rocks and the kinetics and dynamics of crystallization - III. Metamorphic crystallization: Contrib Mineral Petrol, v. 99, no. 4, p. 401-415.

Chakraborty, S., and Ganguly, J., 1992, Cation Diffusion in Aluminosilicate Garnets Experimental-Determination in Spessartine-Almandine Diffusion Couples, Evaluation of Effective Binary Diffusion-Coefficients, and Applications: Contributions to Mineralogy and Petrology, v. 111, no. 1, p. 74-86.

Clark, A.D., Gibson, H.D., Staples, R.D., Israel, S., and Crowley, J.L., 2016, Timing of Mid-Crustal Tectono-Metamorphism in Yukon-Tanana Terrane at Aishihik Lake, Southwest Yukon [abstract]. In: Geological Association of Canada-Mineralogical Association of Canada, Margins Through Time; 2016 June 1-3; Whitehorse, Yukon.

Coggon, R., and Holland, T. J. B., 2002, Mixing properties of phengitic micas and revised garnet-phengite thermobarometers: Journal of Metamorphic Geology, v. 20, no. 7, p. 683-696.

Colpron, M. and Nelson, J.L., 2011. A Digital Atlas of Terranes for the Northern Cordillera. Accessed online from Yukon Geological Survey (www.geology.gov.yk.ca), [2016/12/03]. 
Colpron, M., and Ryan, J. J., 2009, Bedrock geology of southwest McQuesten (NTS 115P) and part of northern Carmacks (NTS 115I) map area: Yukon Exploration and Geology 2009, K.E. MacFarlane, L.H. Weston and L.R. Blackburn (eds.), Yukon Geological Survey, p. 159-184.

Colpron, M., Nelson, J., and Murphy, D. C., 2007, Northern Cordilleran terranes and their interactions through time: GSA Today, v. 17, no. 4/5, p. 4-10.

Connolly, J. A. D., 2005, Computation of phase equilibria by linear programming: A tool for geodynamic modeling and its application to subduction zone decarbonation: Earth and Planetary Science Letters, v. 236, no. 1-2, p. 524-541.

Connolly, J. A. D., 1990, Multivariable Phase-Diagrams - an Algorithm Based on Generalized Thermodynamics: American Journal of Science, v. 290, no. 6, p. 666-718.

Corfu, F., Hanchar, J. M., Hoskin, P. W. O., and Kinny, P., 2003, Atlas of zircon textures: Zircon, v. 53, p. 469-500.

Cygan, R. T., and Lasaga, A. C., 1982, Crystal-Growth and the Formation of Chemical Zoning in Garnets: Contributions to Mineralogy and Petrology, v. 79, no. 2, p. 187200. 
de Capitani, C., and Petrakakis, K., 2010, The computation of equilibrium assemblage diagrams with Theriak/Domino software: American Mineralogist, v. 95, no. 7, p. 1006-1016.

de Capitani, C., and Brown, T. H., 1987, The computation of chemical equilibrium in complex systems containing non-ideal solutions: Geochimica et Cosmochimica Acta, v. 51, no. 10 , p. 2639-2652.

Dickinson, W. R., 2004, Evolution of the North American Cordillera: Annual Review of Earth and Planetary Sciences, v. 32, p. 13-45.

Dodson, M. H., 1973, Closure Temperature in Cooling Geochronological and Petrological Systems: Contributions to Mineralogy and Petrology, v. 40, no. 3, p. 259274.

Duchêne, S., BlichertToft, J., Luais, B., Telouk, P., Lardeaux, J. M., and Albarede, F., 1997, The Lu-Hf dating of garnets and the ages of the Alpine high-pressure metamorphism: Nature, v. 387, no. 6633, p. 586-589.

Duselbacon, C., Hansen, V. L., and Scala, J. A., 1995, High-Pressure Amphibolite Facies Dynamic Metamorphism and the Mesozoic Tectonic Evolution of an Ancient Continental-Margin, East-Central Alaska: Journal of Metamorphic Geology, v. 13, no. 1, p. 9-24. 
Evans, T. P., 2004, A method for calculating effective bulk composition modification due to crystal fractionation in garnet-bearing schist: implications for isopleth thermobarometry: Journal of Metamorphic Geology, v. 22, no. 6, p. 547-557.

Florence, F. P., and Spear, F. S., 1991, Effects of Diffusional Modification of Garnet Growth Zoning on P-T Path Calculations: Contributions to Mineralogy and Petrology, v. 107 , no. 4 , p. $487-500$.

Gagnevin, D., Daly, J. S., and Kronz, A., 2010, Zircon texture and chemical composition as a guide to magmatic processes and mixing in a granitic environment and coeval volcanic system: Contributions to Mineralogy and Petrology, v. 159, no. 4, p. 579-596.

Gaidies, F., Petley-Ragan, A., Chakraborty, S., Dasgupta, S., and Jones, P., 2015, Constraining the conditions of Barrovian metamorphism in Sikkim, India: P-T-t paths of garnet crystallization in the Lesser Himalayan Belt: Journal of Metamorphic Geology, v. 33, no. 1, p. 23-44.

Gaidies, F., Pattison, D. R. M., and de Capitani, C., 2011, Toward a quantitative model of metamorphic nucleation and growth: Contributions to Mineralogy and Petrology, v. 162, no. 5, p. 975-993. 
Gaidies, F., de Capitani, C., and Abart, R., 2008, THERIA_G: a software program to numerically model prograde garnet growth: Contributions to Mineralogy and Petrology, v. 155, no. 5, p. 657-671.

Gaidies, F., Abart, R., De Capitani, C., Schuster, R., Connolly, J. A. D., and Reusser, E., 2006, Characterization of polymetamorphism in the Austroalpine basement east of the Tauern Window using garnet isopleth thermobarometry: Journal of Metamorphic Geology, v. 24, no. 6, p. 451-475.

Garcia, D., Coelho, J., and Perrin, M., 1991, Fractionation between $\mathrm{TiO}_{2}$ and $\mathrm{Zr}$ as a measure of sorting within shale and sandstone series (Northern Portugal): European Journal of Mineralogy, v. 3, no. 2, p. 401-411.

George, F. R., and Gaidies, F., 2017, Characterisation of a garnet population from the Sikkim Himalaya: insights into the rates and mechanisms of porphyroblast crystallisation: Contributions to Mineralogy and Petrology, v. 172, no. 7, 22 p.

Gordey, S. P., and Ryan, J. J., 2005, Geology, Stewart River area (115 N, 115-O and part of 115J), Yukon Territory; Geological Survey of Canada, Open File 4970, scale 1:250 000.

Herron, M. M., 1988, Geochemical Classification of Terrigenous Sands and Shales from Core or Log Data: Journal of Sedimentary Petrology, v. 58, no. 5, p. 820-829. 
Hickmott, D. D., Shimizu, N., Spear, F. S., and Selverstone, J., 1987, Trace-Element Zoning in a Metamorphic Garnet: Geology, v. 15, no. 6, p. 573-576.

Holland, T. J. B., and Powell, R., 1998, An internally consistent thermodynamic data set for phases of petrological interest: Journal of Metamorphic Geology, v. 16, no. 3, p. 309-343.

Hollister, L. S., 1966, Garnet Zoning: An Interpretation Based on the Rayleigh Fractionation Model: Science, v. 154, no. 3757, p. 1647-1651.

Inui, M., and Toriumi, M., 2004, A Theoretical Study on the Formation of Growth Zoning in Garnet Consuming Chlorite: Journal of Petrology, v.45, no. 7, p. 1369-1392.

Jennings, R. J., 1988, A method for comparing beam-hardening filter materials for diagnostic radiology: Med Phys, v. 15, no. 4, p. 588-599.

Johnston, S. T., Canil, D., and Heaman, L. H., 2007, Permian exhumation of the Buffalo Pitts orogenic peridotite massif, northern Cordillera, Yukon: Canadian Journal of Earth Sciences, v. 44, no. 3, p. 275-286,10.1139/e06-078. 
Joyce, N. L., Ryan, J. J., Colpron, M., Hart, C. J. R., and Murphy, D. C., 2015, A compilation of 40Ar/39Ar age determinations for igneous and metamorphic rocks, and mineral occurrences from central and southeast Yukon: Geological survey of Canada, Open File 7924, 1 .zip file. doi:10.4095/297446.

Kelly, E. D., Carlson, W. D., and Connelly, J. N., 2011, Implications of garnet resorption for the Lu-Hf garnet geochronometer: an example from the contact aureole of the Makhavinekh Lake Pluton, Labrador: Journal of Metamorphic Geology, v. 29, no. 8, p. $901-916$.

Ketcham, R. A., 2005, Computational methods for quantitative analysis of threedimensional features in geological specimens: Geosphere, v. 1, no. 1, p. 32-41.

Knight, E., Schneider, D. A., and Ryan, J., 2013, Thermochronology of the YukonTanana Terrane, West-Central Yukon: Evidence for Jurassic Extension and Exhumation in the Northern Canadian Cordillera: The Journal of Geology, v. 121, no. 4, p. 371-400.

Kohn, M. J., 2009, Models of garnet differential geochronology: Geochimica Et Cosmochimica Acta, v. 73, no. 1, p. 170-182.

Kohn, M. J., and Spear, F., 2000, Retrograde net transfer reaction insurance for pressuretemperature estimates: Geology, v. 28, no. 12, p. 1127-1130. 
Lee, D. C., Halliday, A. N., Hein, J. R., Burton, K. W., Christensen, J. N., and Gunther, D., 1999, Hafnium isotope stratigraphy of ferromanganese crusts: Science, v. 285, no. 5430, p. 1052-1054.

Logan, J.M. and Mihalynuk, M.G., 2014, Tectonic Controls on Early Mesozoic Paired Alkaline Porphyry Deposit Belts $(\mathrm{Cu}-\mathrm{Au} \pm \mathrm{Ag}-\mathrm{Pt}-\mathrm{Pd}-\mathrm{Mo})$ Within the Canadian Cordillera; Economic Geology, v. 109, pp. 827-858.

Ludwig, K. R., 2008, Isoplot. A Geochonological Toolkit for Microsoft Excel: Berkley Geochronology Centre, Special Publication, v. 4, p. 77.

Monger, J. W. H., and Price, R. A., 2002, The Canadian Cordillera: Geology and Tectonic Evolution: Canadian Society of Exploration Geophysicists Recorder, v. 27, p. 17-36.

Morneau, Y. E., Gaidies, F., Ryan, J. J., Zagorevski, A., (in press), Estimates of garnet crystallization and rates of metamorphism for metapelites of the Snowcap Assemblage, Yukon-Tanana terrane, Yukon: Geological Survey of Canada, Current Research.

Nelson, J., Colpron, M., Israel, S., Bissig, T., Rusk, B. G., and Thompson, J. F. H., 2013, The Cordillera of British Columbia, Yukon, and Alaska; tectonics and metallogeny: Special Publication [Society of Economic Geologists [U. S.]], v. 17, p. 53-109. 
Norrish, K., and Hutton, J. T., 1969, An accurate X-ray spectrographic method for the analysis of a wide range of geological samples: Geochimica et Cosmochimica Acta, v. 33, no. 4, p. 431-453.

Patchett, P. J., and Tatsumoto, M., 1980, A Routine High-Precision Method for Lu-Hf Isotope Geochemistry and Chronology: Contributions to Mineralogy and Petrology, v. 75 , no. 3 , p. $263-267$.

Pattison, D. R. M., De Capitani, C., and Gaidies, F., 2011, Petrological consequences of variations in metamorphic reaction affinity: Journal of Metamorphic Geology, v. 29, no. 9, p. 953-977.

Pattison, D. R. M., and Tinkham, D. K., 2009, Interplay between equilibrium and kinetics in prograde metamorphism of pelites: an example from the Nelson aureole, British Columbia: Journal of Metamorphic Geology, v. 27, no. 4, p. 249-279.

Pearce, J. A., 1996, A user's guide to basalt discrimination diagrams, in Wymna, D. A. ed., Trace Element Geochemistry of Volcanic Rocks: Applications for Massive Sulphide Exploration: Geological Association of Canada, Short Course Notes, v. 12, p. $79-113$. 
Piercey, S. J., and Colpron, M., 2009, Composition and provenance of the Snowcap assemblage, basement to the Yukon-Tanana terrane, northern Cordillera: Implications for Cordilleran crustal growth: Geosphere, v. 5, no. 5, p. 439-464.

Pin, C., and Zalduegui, J. F. S., 1997, Sequential separation of light rare-earth elements, thorium and uranium by miniaturized extraction chromatography: Application to isotopic analyses of silicate rocks: Analytica Chimica Acta, v. 339, no. 1-2, p. 79-89.

Powell, R., and Holland, T. J. B., 1988, An Internally Consistent Dataset with Uncertainties and Correlations .3. Applications to Geobarometry, Worked Examples and a Computer-Program: Journal of Metamorphic Geology, v. 6, no. 2, p. 173-204.

Roser, B. P., and Korsch, R. J., 1986, Determination of Tectonic Setting of SandstoneMudstone Suites Using Sio2 Content and K2o Na2o Ratio: Journal of Geology, v. 94, no. 5 , p. 635-650.

Rubie, D. C., 1998, Disequilibrium during metamorphism: the role of nucleation kinetics: What Drives Metamorphism and Metamorphic Reactions?, v. 138, p. 199-214.

Ruks, T. W., Piercey, S. J., Ryan, J. J., Villeneuve, M. E., and Creaser, R. A., 2006, Midto late Paleozoic K-feldspar augen granitoids of the Yukon-Tanana terrane, Yukon, Canada: Implications for crustal growth and tectonic evolution of the northern Cordillera: Geological Society of America Bulletin, v. 118, no. 9-10, p. 1212-1231. 
Ryan, J. J., Zagorevski, Z., Roots, C. F., and Joyce, N., 2014, Paleozoic tectonostratigraphy of the northern Stevenson Ridge area, Yukon: Geological Survey of Canada, Current Research 2014-4, p. 13.

Scherer, E. E., Cameron, K. L., and Blichert-Toft, J., 2000, Lu-Hf garnet geochronology: Closure temperature relative to the $\mathrm{Sm}-\mathrm{Nd}$ system and the effects of trace mineral inclusions: Geochimica Et Cosmochimica Acta, v. 64, no. 19, p. 3413-3432.

Siivola, J. and Schmid, R., 2007, Recommendations by the IUGS Subcommission on the Systematics of Metamorphic Rocks: List of mineral abbreviations: Web version 01.02.07. (http://www.bgs.ac.uk/scmr/docs/papers/paper_12.pdf) IUGS Commission on the Systematics in Petrology.

Smit, M. A., Scherer, E. E., and Mezger, K., 2013, Lu-Hf and Sm-Nd garnet geochronology: Chronometric closure and implications for dating petrological processes: Earth and Planetary Science Letters, v. 381, p. 222-233.

Spear, F. S., 1993, Metamorphic Phase Equilibria and Pressure-Temperature-Time Paths, Mineralogical Society of America, Washington, D. C., 799 p.

Spear, F. S., Kohn, M. J., Florence, F. P., and Menard, T., 1991, A model for garnet and plagioclase growth in politic schists: implications for thermobarometry and P-T path determinations: Journal of Metamorphic Geology, v. 8, p. 683-696. 
Staples, R., Gibson, H. D., Colpron, M., and Ryan, J. J., 2016, An orogenic wedge model for diachronous deformation, metamorphism, and exhumation in the hinterland of the northern Canadian Cordillera: Lithosphere, v. 8, no. 2, p. 165-184.

Staples, R. D., Murphy, D. C., Gibson, H. D., Colpron, M., Berman, R. G., and Ryan, J. J., 2014, Middle Jurassic to earliest Cretaceous mid-crustal tectono-metamorphism in the northern Canadian Cordillera: Recording foreland-directed migration of an orogenic front: Geological Society of America Bulletin, v. 126, no. 11-12, p. 15111530.

Staples, R. D., Gibson, H. D., Berman, R. G., Ryan, J. J., and Colpron, M., 2013, A window into the Early to mid-Cretaceous infrastructure of the Yukon-Tanana terrane recorded in multi-stage garnet of west-central Yukon, Canada: Journal of Metamorphic Geology, v. 31, no. 7, p. 729-753.

Symmes, G. H., and Ferry, J. M., 1991, Evidence from Mineral Assemblages for Infiltration of Pelitic Schists by Aqueous Fluids during Metamorphism: Contributions to Mineralogy and Petrology, v. 108, no. 4, p. 419-438.

Van Orman, J. A., Grove, T. L., Shimizu, N., and Layne, G. D., 2002, Rare earth element diffusion in a natural pyrope single crystal at $2.8 \mathrm{GPa}$ : Contributions to Mineralogy and Petrology, v. 142, no. 4, p. 416-424. 
Waters, D. J., and Lovegrove, D. P., 2002, Assessing the extent of disequilibrium and overstepping of prograde metamorphic reactions in metapelites from the Bushveld Complex aureole, South Africa: Journal of Metamorphic Geology, v. 20, no. 1, p. 135149.

White, R. W., Powell, R., and Holland, T. J. B., 2007, Progress relating to calculation of partial melting equilibria for metapelites: Journal of Metamorphic Geology, v. 25, no. 5, p. $511-527$.

White, R. W., Pomroy, N. E., and Powell, R., 2005, An in situ metatexite-diatexite transition in upper amphibolite facies rocks from Broken Hill, Australia: Journal of Metamorphic Geology, v. 23, no. 7, p. 579-602.

Woodsworth, G. J., Anderson, R. G., and Armstrong, R. L., 1991, Plutonic regimes, in Gabrielse, H., and Yorath, C. J., eds., Geology of the Cordilleran Orogen in Canada, Volume Geology of Canada 4, Geological Survey of Canada, p. 491-531. 